NAA-SR-3379

SPECIAL

PAGES

COPY 36

\title{
PRELIMINARY SAFEGUARDS REPORT \\ BASED ON URANIUM-MOLYBDENUM FUEL \\ FOR THE \\ HALLAM NUCLEAR POWER FACILITY
}

NAA-SR-3379

\section{.}

General Editor

THEODORE L. GERSHUN

Principal Contributors

EDWARD B. ASH

WILLIAM J. CUDAHY

DONALD E. FLETCHALL

R. CLYDE GERBER, JR.
THEODORE L. GERSHUN

JOHN P. HALE, JR.

BOYD E. HARPER, JR.

JOSEPH REICHMAN

\section{ATOMICS INTERNATIONAL}

A DIVISION OF NORTH AMERICAN AVIATION, INC.

P.O. BOX 309

CANOGA PARK, CALIFORNIA

CONTRACT: AT(11-1)-GEN-8

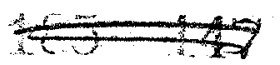

LEGAL NOTICE

Thls report was prepared as an. account of Government aponsored work. Netther the Dnited States, nor the Commisston, nor any person settng on behalf of the comimisstion:

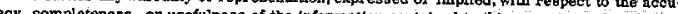
of any fnformation, apparatus, method, or proces dinglosed in the report, or that the use

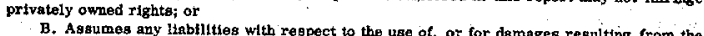

of any information, altes with respect to the use of, or for drages resulting from the Aparas, method, or procosa disclosed in this repar.

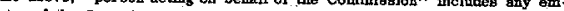

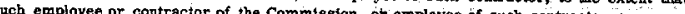

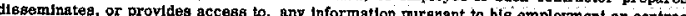
with the Commiseton, or hlis employment with such contractor. 


\section{DISCLAIMER}

This report was prepared as an account of work sponsored by an agency of the United States Government. Neither the United States Government nor any agency Thereof, nor any of their employees, makes any warranty, express or implied, or assumes any legal liability or responsibility for the accuracy, completeness, or usefulness of any information, apparatus, product, or process disclosed, or represents that its use would not infringe privately owned rights. Reference herein to any specific commercial product, process, or service by trade name, trademark, manufacturer, or otherwise does not necessarily constitute or imply its endorsement, recommendation, or favoring by the United States Government or any agency thereof. The views and opinions of authors expressed herein do not necessarily state or reflect those of the United States Government or any agency thereof. 


\section{DISCLAIMER}

Portions of this document may be illegible in electronic image products. Images are produced from the best available original document. 
Introduction

$\mathbf{x i}$

PAR T ONE - DESCRIPTION OF THE HNPF

I. Compendium - Part One . . . . . . . . . . . . . I-1

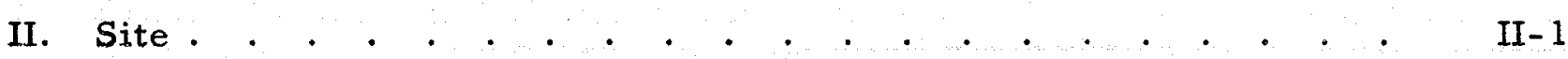

A. Topography . . . . . . . . . . . . . . . . . II-1

B. Population Distribution . . . . . . . . . . . . II-1

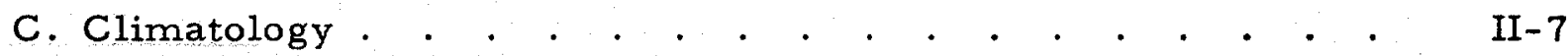

D. Meteorology . • . . . . . . . . . . . . . . . . II-7

E. Seismology • • • . . . . . . . • . . . . . . . II-14

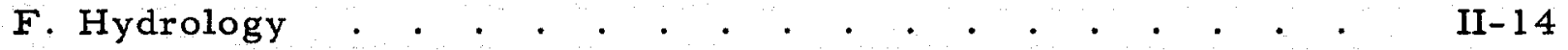

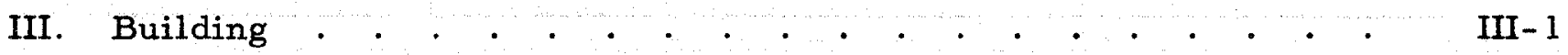

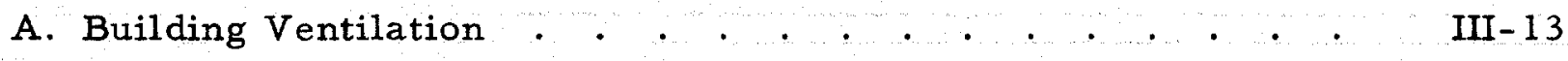

B. Maintenance Cell . . . . . . . . . . . . III-14

C. Decontamination Room . . . . . . . . . . . . . III-16

D. Fire Protection Systems . . . . . . . . . . . . III-17

IV. The Reactor and Associated Heat Transfer System . . . . . . IV -1

A. Reactor . . . . . . . . . . . . . . IV -3

B. Sodium Heat Transfer System . . . . . . . . . . . . IV-19

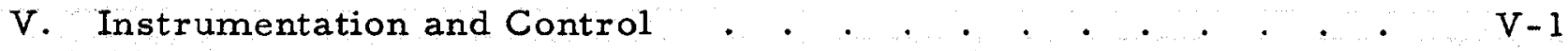

A. Nuclear Instrumentation . . . . . . . . . . . . . . . . . V-1

B. Sodium Instrumentation . . . . . . . . . . . V V

C. Plant Control System . . • . . . . . . . . . . . V V-4

D. Protective System . . . . . . . . . . . . . . . . . . V -7

E. Radiation Monitoring System . . . . . . . . . . . . V-15

VI. Auxiliary Systems . . . . . . . . . . . . . . . . . VI-1

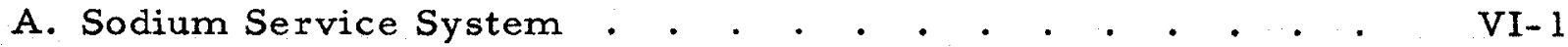

B. Organic Cooling System . . . . . . . . . . . . . . VI-6

C. Water Cooling System

D. Helium System - . . . . . . . . . . . . . . . V VI-10

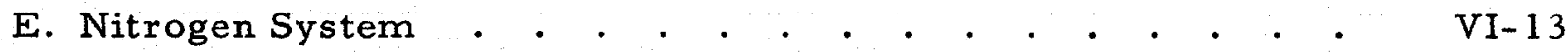

F. Radioactive Vent System. . . . . . . . . . . . . . VI-15

G. Radioactive Liquid Waste System . . . . . . . . . . . VI-18

H. Electrical Power Supply . . . . . . . . . . . . . . VI-20 


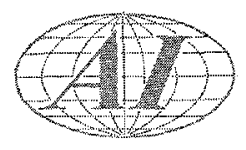

\section{CONTENTS (Continued)}

Page

VII. Fuel and Component Handling Facilities . . . . . . . . VII-1

A. System and Component Description . . . . . . . . . VII-1

B. Fuel and Core Component Handling . . . . . . . . . . VII-6

PART TWO - POTENTIAL HAZARDS AND CONTROLLING SAFEGUARDS FOR THE HNPF

VIII. Compendium - Part Two . . . . . . . . . . . . . . V VIII-1

IX. Confinement of Radioactivity . . . . . . . . . . . . . IX-1

A. Safeguards for Confinfing Radioactivity . . . . . . . . IX-1

B. Potential Hazards from Chemical Reactions and Wigner

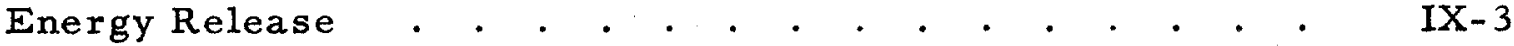

C. Potential Hazards from Fuel Element Failure . . . . . IX-4

D. Potential Hazards from Moderator and Reflector Element Failures . . . . . . . . . . . . . . . IX 5

E. Potential Hazard from Control Rod Thimbles . . . . . . IX-5

F. Safeguards Against Damage to Control Rod Housing . . . . I I

G. Potential Hazards from Failure Within the Reactor

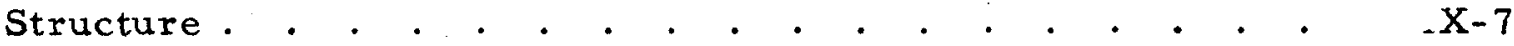

H. Potential Hazards from the Primary Sodium System . . . IX-10

I. Potential Hazard from the Secondary Sodium System . IX-12

J. Potential Hazard from the Sodium Pumps . . . . . . . IX-13

K. Potential Hazard from the Sodium Valves . . . . . . . IX-14

L. Potential Hazard from Leakage in the Intermediate Heat Exchangers . . . . . . . . . . . . . . . . . IX-14

M. Potential Hazard from Leakage in the Steam Generator . . IX-14

N. Potential Hazards from the Fuel Handling System . . . . IX-15

X. Radiological Considerations . . . . . . . . . . . . . X-1

A. Radiation Levels During Normal Operations . . . . . . $\mathrm{X}-2$

B. Radioactive Release to the Building Atmosphere . . . . . X X-6

C. Radioactive Release from the Stack . . . . . . . . . . X-9

D. Consequences of a Major Release of Gaseous Fission Products . . . . . . . . . . . . . . . . . . $\mathrm{X}-11$ 


\section{CONTENTS (Continued)}

Page

E. Consequences of a Major Hypothetical Release of Primary Sodium . . . . . . . . . . . . . X-14

F. Emergency Procedures . . . . . . . . . . . . X-16

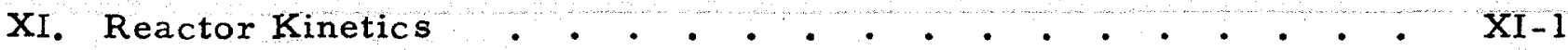

A. Nuclear and Kinetics Parameters . . . . . . . . . XI-1

B. Reactor Core Dynamics . . . . . . . . . . . XI-9

XII. Transients with Protective System Action . . . . . . . . XII-1

A. Startup Transient from Source Level . . . . . . . . XII-3

B. Rod-Withdrawal Transient from High Reactor Power Level . XII-7

C. Rod-Withdrawal Transient from Low Reactor Power Level . XII-10

D. Loss of Coolant Flow Transient . . . . . . . . . XII-11

E. Reactor Inlet Coolant Temperature Transient . . . . . XII-17

F. Protective System Summary . - . . . . . . . . . XII-18

XIII. Transients Without Protective System Action . . . . . . . XIII-I

A. Safeguards Against Nuclear Excursions . . . . . . . XIII-1

B. Ultimate Shutdown Mechanism for Uncontrolled Excursions . XIII-6

C. Nuclear Transients . . . . . . . . . . . . . XIII-14

D. Loss of Reactor Heat Sink . . . . . . . . . . . . XIII-22

XIV. Accident Evaluation and Conclusions . . . . . . . . . . XIV-1

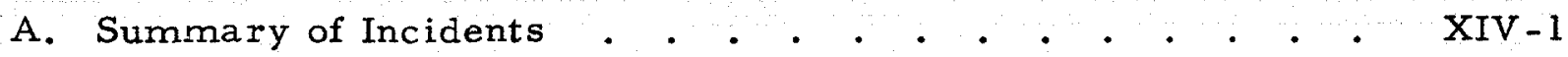

B. The Maximum Credible Accident. . . . . . . . . . XIV -1

Appendix A. Autocatalytic Release of Wigner Energy in the HNPF . . A-1

Appendix B. Description of Reactor Power and Temperature

Transient Studies . . . . . . . . . . . . B-1

A. Analog Model . . . . . . . . . . . . . . . B-1

B. Analog Simulator Program . . . . . . . . . . . B-4 


\section{TABLES - PART I}

Page

I. Population Density Summary . . . . . . . . . . . II-8

II. Hourly Average Wind Velocity for Percent of Year for Lincoln, Nebraska . . . . . . . . . . . . . . II-9

III. High-Altitude Sea sonal Mean Winds . . . . . . . . II-10

IV. Meteorological Data for Proposed Nuclear Power Plant Site . . . . . . . . . . . . . . . . . II-13

V. Design Features . . . . . . . . . . . . . . . IV-2

VI. Reactor Operating Data . . . . . . . . . . . . IV-6

VII. Primary and Secondary Pump Design . . . . . . . IV-24

VIII. Regulating Elements and Controlled Quantities . . . . . V-7

IX. Power Setback . . . . . . . . . . . . . . . V-11

$\mathrm{X}$. Reactor Scram Signals. . . . . . . . . . . . . V-13

\section{TABLES - PART II}

XI. Interlocks between Mobile Equipment . . . . . . . . IX-7

XII. Sources and Activity Levels . . . . . . . . . . . X-3

XIII. Activity Level of Radioactive Gases . . . . . . . . X-4

XIV. Effective Stack Height . . . . . . . . . . . . . X-9

XV. Parameters for Downwind Activity. . . . . . . . . X-10

XVI. Dose Rate due to Major Release of Gaseous Fission

Products - Stack Release . . . . . . . . . . . . X-13

XVII. Dose Rate due to Major Release of Gaseous Fission

Products - Ground Release . . . . . . . . . . . X-14

XVIII. Dose Rate due to Major Release of Primary Sodium -

Stack Release. . . . . . . . . . . . . . . . $\mathrm{X}-15$

XIX. Dose Rate due to Major Release of Primary Sodium -

Ground Release . . . . . . . . . . . . . X-15

XX. Excess Reactivity Requirements . . . . . . . . . XI-1

XXI. Reactivity Worth of Rods . . . . . . . . . . . . XI-2

XXII. Summary of Potential Hazards . . . . . . . . . . XIV-2 


\section{FIGURES}

Page

Legend for Figures.

1. HNPF-Site Plan

2. HNPF-Site Contour Elevations . . . . . . . . . . . II-5

3. Map of HNPF Area . . . . . . . . . . . . . . . . II-6

4. Average Rural-Population Density in the Vicinity of the HNPF Site . . . . . . . . . . . . . II-8

5. Monthly Wind-Rose Data (5-yr average) . . . . . . . . II-11

6. Yearly Wind-Rose Data (5-yr average) . . . . . . . . II-12

7. Map of the United States Showing Epicenter and the Relative Destructiveness of Earthquakes through 1951 . . . . . . II-15

8. Reactor-Building-Layout Plan above Elevation of $1460 \mathrm{ft}$. . III-3

9. Reactor-Building-Layout Plan below Elevation of $1460 \mathrm{ft}$. . III-6

10. Reactor-Building-Layout Plan below Elevation of $1440 \mathrm{ft}$. . III-9

11. Vertical Sections through Reactor Building . . . . . . . III-11

12. Reactor General Arrangement . . . . . . . . . . . IV -4

13. Fuel Element Assembly . . . . . . . . . . . . . . IV-7

14. Moderator-Reflector Element . . . . . . . . . . . IV -9

15. Shim-Regulating Rod . . . . . . . . . . . . . . IV-12

16. Safety Rod . . . . . . . . . . . . . . . . . IV-13

17. Reactor Cavity Liner . . . . . . . . . . . . . IV-17

18. Sodium Heat Transfer Circuit . . . . . . . . . . . IV -20

19. Primary Sodium Pump . . . . . . . . . . . . . . IV -23

20. Steam Dumping System . . . . . . . . . . . . . . IV I 27

21. Feedwater System . . . . . . . . . . . . IV - 28

22. Nuclear Instrumentation - . . . . . . . . . . . . V V-2

23. Plant Control System . . . . . . . . . . . . . V - . 5

24. Protective System . . . . . . . . . . . . . . . . V - 10

25. Radiation Monitoring System . . . . . . . . . . . . V V-17

26. Sodium Service System - . . . . . . . . . . . . . VI-2

27. Organic Cooling System . . . . . . . . . . . . . VI-7

28. Water Cooling System . . . . . . . . . . . . . . . VI-9

29. Helium System . . . . . . . . . . . . . . . . . VI-11 


\section{FIGURES (Continued)}

Page

30. Nitrogen System

VI -14

31. Radioactive Vent System

VI- 16

32. Radioactive Liquid Waste System . . . . . . . . . . V VI-19

33. Electrical System

VI-21

34. Fuel Handling Cạsk . . . . . . . . . . . . . . . VII-2

35. Reactor Helium Atmosphere Supply and Vent System . . . IX-9

36. Dose Rate in High-Bay Area Resulting from Radioactive Sodium Spill

37. Ground-Level Activity Concentration Downwind of the Facility Resulting from Release of Radioactivity from Stack (X/Q = activity concentration per unit stack discharge rate) . .

38. Steady State Power Coefficient as a Function of Fraction of Rated Core Sodium Flow Rate . . . . . . . . . . . X XI-6

39. Stable Period as a Function of Excess Reactivity . . . . . XI-10

40. Zero-Power Reactor Transfer Function . . . . . . . . XI-11

41. Long-Term Transient Response of Reactor . . . . . . . XI-13

42. Open Loop Reactor Transfer Function . . . . . . . . . . XI-14

43. Full Power, Full Flow Transfer Function of Reactor Core . . XI-15

44. Short-Term Transient Response of Reactor . . . . . . . XI-16

45. Temperatures and Relative Neutron Flux for Startup Transient with Protective-System Low-Level Scram at $\mathrm{N} / \mathrm{N}_{\mathrm{O}}=0.20$.

46. Temperatures and Relative Neutron Flux for Startup Transient with Protective-System Low-Level Scram at $N / N_{0}=0.20$. . XII-5

47. Power-Flow-Ratio Operating Curve . . . . . . . . . XII-6

48. Temperatures and Relative Neutron Flux for Rod-Withdrawal Transient with Protective System Power-Flow-Ratio Scram

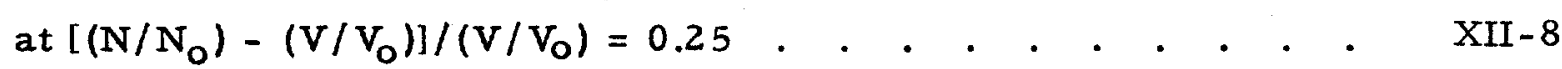

49. Temperatures and Relative Neutron Flux for Rod-Withdrawal Transient with Protective System Power-Flow-Ratio Scram at $\left[\left(\mathrm{N} / \mathrm{N}_{\mathrm{O}}\right)-\left(\mathrm{V} / \mathrm{V}_{\mathrm{O}}\right)\right] /\left(\mathrm{V} / \mathrm{V}_{\mathrm{O}}\right)=0.25$ 


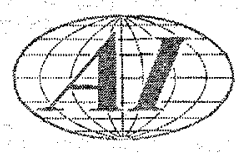

\section{FIGURES (Confinued)}

Page

50. Temperatures and Relative Neutron Flux for Rod-Withdrawal Transient with Protective System Coolant Temperature Scram

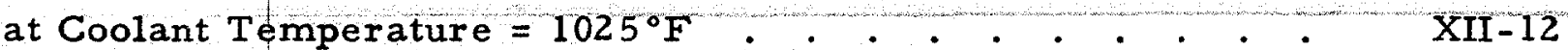

51. Temperatures and Relative Neutron Flux for Rod-Withdrawal Transient with Protective System Coolant Temperature Scram at Coolant Temperature of $1025^{\circ} \mathrm{F}$. . . . . . . . . . . XII-13

52. Temperatures and Relative Neutron Flux for Loss of Primary-Coolant-Flow Transient with Protective System Scram from Power-Flow-Ratio . . . . . . . . . . . . XII-15

53. Flow Decay Curve Following Loss of Pumping Power for Primary Coolant • • • • • • • • • • • • • XII-16

54. Core $\Delta P$ as a Function of Power and Flow in HNPF Center Channel .

55. Temperatures and Relative Neutron Flux for Startup Transient Without Protective System Action . . . . . • . . • . XIII-14

56. Temperatures and Relative Neutron Flux for Rod-Withdrawal Transient from Full Power Without Protective System Action . . . . . . . . . . . . . . . . . . XIII-15

57. Temperatures and Relative Neutron Flux for Rod-Withdrawal Transient from Full Power Without Protective System Action . . . . . . . . . . . . . . . . XIII-16

58. Temperatures and Relative Neutron Flux for Loss-of-PrimaryCoolant-Flow Transient Without Protective System Action XIII- 18

59. Wigner Energy Storage in Graphite.

60. Variation of Graphite Specific Heat with Measurement Temperature . • . • . . . . . . . . . . A-4

61. Unit Cell Model for Representative Fuel Channel and Graphite Moderator Can . . . . . . . . . . B-2

62. Schematic of Analog Computer Program for Transient Simulation . . . . . . . . . . . . . . . 


\section{LEGEND FOR FIGURES}

VALVES

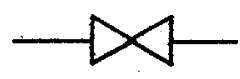

GATE

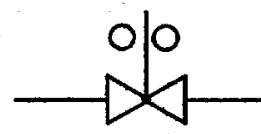

ORGANIC COOLED

FREEZE SEAL

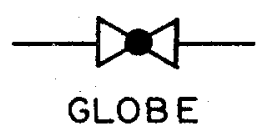

GLOBE

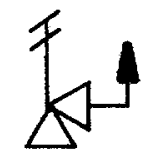

RELIEF
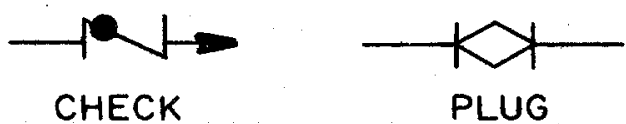

PLUG

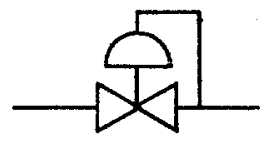

PRESSURE CONTROL

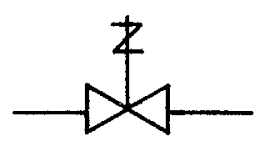

BELLOWS

SEAL

INSTRUMENT LETTER DESIGNATION

\begin{tabular}{|c|c|c|c|}
\hline & FIRST & SECOND & THIRD \\
\hline$A$ & & ALARM & AMPLIFIER \\
\hline$C$ & & CONTROL & CONTROL \\
\hline$C P$ & & COMPUTER & COMPUTER \\
\hline$D$ & & DETECTOR & \\
\hline$E$ & & ELEMENT & ELEMENT \\
\hline$F$ & FLOW & FISSION & HIGH \\
\hline$H$ & HAND & INDICATING & INDICATING \\
\hline$I$ & & LINEAR & LOW \\
\hline$L$ & LEVEL & LOG & \\
\hline$L G$ & & MONITOR & \\
\hline$M$ & & & POWER \\
\hline$N$ & NEUTRON & PERIOD (PREAMP) & \\
\hline$P$ & PRESSURE & RECORDING & RECORDING \\
\hline PN & POSITION & SAFETY & STATION \\
\hline$R$ & RADIOACTIVITY & TAP & \\
\hline$S$ & SPEED AND MOTION & SCRAM & \\
\hline$T$ & TEMPERATURE & SET BACK & \\
\hline$I$ & $X$ & &
\end{tabular}

$N / N_{0}=\frac{\text { NEUTRON FLUX }}{\text { NEUTRON FLUX AT } 100 \% \text { POWER }}$

$V / V_{0}=\frac{\text { COOLANT FLOW RATE }}{\text { COOLANT FLOW RATE AT } 100 \% \text { POWER }}$ 


\section{INTRODUCTION}

The Hallam Nuclear Power Facility (HNPF) has been authorized by the United States Atomic Energy Commission as part of the program to demonstrate the technical and economic feasibility of using nuclear reactors for central station power. The HNPF consists of a 240-Mwt Sodium Graphite Reactor (SGR) and the associated equipment for generating electrical power. The use of the SGR concept for this facility is intended to utilize and extend the knowledge gained from the operation of the Sodium Reactor Experiment, which Atomics International built and has operated successfully for the AEC since July 12, 1957.

The HNPF will be located in southeastern Nebraska at the Sheldon Station of the Consumers Public Power District (CPPD).

An option to buy this particular site was obtained by CPPD in 1955. The option was contingent on the acceptance of the site by the AEC for the location of a nuclear power plant. CPPD exercised its option in 1956 after the site was reviewed and accepted by the Advisory Committee on Reactor Safety.

Until the HNPF is completed, the power demands of the area serviced by CPPD will be met by means of a conventional, fossil-fired (coal) boiler which will supply steam to the turbine-generator at the Sheldon Station. Later, when the reactor is undergoing startup, and the plant equipment is being checked out, the turbine-generator will be supplied with steam produced by the nuclear facility, and the conventional boiler will be used on a standby basis. After the reactor reaches full-power operation, increasing power demands of the area may be fulfilled by using the conventional boiler to supply steam for a second turbinegenerator.

The original plans for the HNPF included using $\mathrm{UO}_{2}$ as the reactor fuel; however, late in the fall of 1958, it was decided that the initial fuel loading in the reactor would be U-10 w/o Mo. This report is based on the use of U-10 w/o Mo as the reactor fuel; and the reactor description presented here is therefore different from that presented in "Preliminary Design Proposal for the Hallam Nuclear Facility," NAA-SR-2960. 


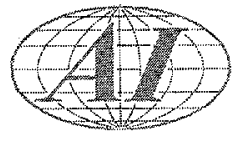

Future plans for the HNPF include two additional facilities which have not as yet been included in the plant design. One of these is a Food Irradiation Facility which would employ radioactive sodium from the nuclear reactor as a direct source of $\gamma$-rays; the second is a facility for the processing and packaging of radioactive waste for future disposal. Since these additional facilities are still in the realm of future plans, no discussion of them is included here.

This report is divided into two parts: a description of the facility (Part I), and an analysis of the potential hazards and the controlling safeguards (Part II). A compendium of Part $I$ is presented in section I; a compendium of Part II in section VIII. 


\section{COMPENDIUM - PART ONE}

The Hallam Nuclear Power Facility (HNPF) consists of a 240-Mwt Sodium Graphite Reactor and the associated equipment for generating electrical power. The HNPF is located in a sparsely settled area in southeastern Nebraska, 19 miles from Lincoln. The site was selected with special consideration given to the requirements for a nuclear power plant.

The reactor building consists of a high-bay area for the reactor and its heat transfer system, a low-bay area for the reactor service systems, and an administrative wing. The high-bay area is serviced with a bridge crane for heavy equipment handling and a gantry-supported cask for fuel handling. A second bridge crane serves the low-bay area.

The reactor is sodium cooled, graphite moderated, and uses uranium alloyed with molybdenum as a fuel. The sodium, which becomes radioactive as it is heated in the reactor core, is pumped through three separate primary loops. Each loop has a heat exchanger in which the energy is transferred from the radioactive primary sodium loop to a nonradioactive secondary sodium loop. Each of the three secondary loops, containing nonradioactive sodium, has a steam generator in which feedwater is evaporated and the resulting steam is superheated. The steam from the three steam generators is fed into a common header which serves the turbine-generator.

A sodium service system is used to fill, drain, and flush the reactor vessel and the sodium heat transfer systems. This service system also includes purification equipment to remove oxides from the sodium. A helium system provides an inert gas atmosphere within the reactor and within the sodium systems, and a nitrogen system furnishes an inert gas atmosphere within the shielded cells in which the primary sodium system components are located. Also, there are systems to remove, store, and dispose of radioactive gases and radioactive liquid wastes. A water cooling system is used for auxiliary cooling of equipment where no potential danger exists of a water-sodium reaction. An organic cooling system provides cooling for the reactor loading face shield and for sodium system components where there is close proximity of auxiliary coolant and sodium. 
The fuel and component handling system consists of a fuel handling cask, fuel storage and fuel cleaning cells, and all the necessary equipment for receiving, handling, storage, and shipment of fuel elements, control rods, moderator elements, and other replaceable core components. Facilities are also provided for handling and shipping replaceable components such as pumps and cold traps.

The plant control system automatically operates the plant as a load-following central-station power plant when the load is between 20 and $100 \%$ of full load, and provides for manual or semiautomatic plant control at any load. In addition, a plant protective system provides for rapid detection of any off-normal condition in the plant and automatically takes corrective action. 


\section{SITE*}

The site (Figure 1) for the Hallam Nuclear Power Facility is located in Lancaster County in southeastern Nebraska. The facility is near the center of Section 19 in Township 7 North, Range 6 East. The site was selected by first considering the general area in which an additional power supply is required. Next, those areas which did not contain adequate water supplies were excluded from consideration. Then the influence of population distribution, hydrological characteristics, climatology, and seismological characteristics was considered so as to minimize the radiation exposure to the public should a radioactive incident occur.

\section{A. TOPOGRAPHY}

The terrain at the site is the rolling hills and valleys typical of the Loess Sections of the Great Plains region of the United States. Ground elevation at the reactor facility (Figure 2) is approximately $1440 \mathrm{ft}$ above sea level. The site is near the high point of terrain which gradually recedes to the north and east to form the valley of the Platte River

Two all-weather roads, Lincoln Way from the north and Hallam Way from the south, provide vehicle access to the reactor site. A spur track from the Rock Island and Pacific Railroad, which runs along the eastern edge of Section 19, provides rail access to the site. Airfields are located at Lincoln, 19 miles to the northeast; Crete, 10 miles to the northwest; Wilbur, 10 miles to the southwest; and Beatrice, 19 miles to the south. A map (Figure 3) is included for reference.

\section{B. POPULATION DISTRIBUTION}

The lands adjacent to the site are sparsely settled. Farms and small communities are typical of the area. Within a radius of $1 / 2$ mile of the plant there are no inhabited dwellings or residences. The village of Hallam, population 172, located $1-1 / 2$ miles south of the site is the closest concentration of population. The nearest small town is Crete, population 3692, located 10 miles to the northwest. The largest cities in the area are Lincoln (19 miles north),

* For a more detailed site description see "Site Data for the Proposed Nebraska Nuclear Power Plant," CPPD-25, September 22, 1955 . 


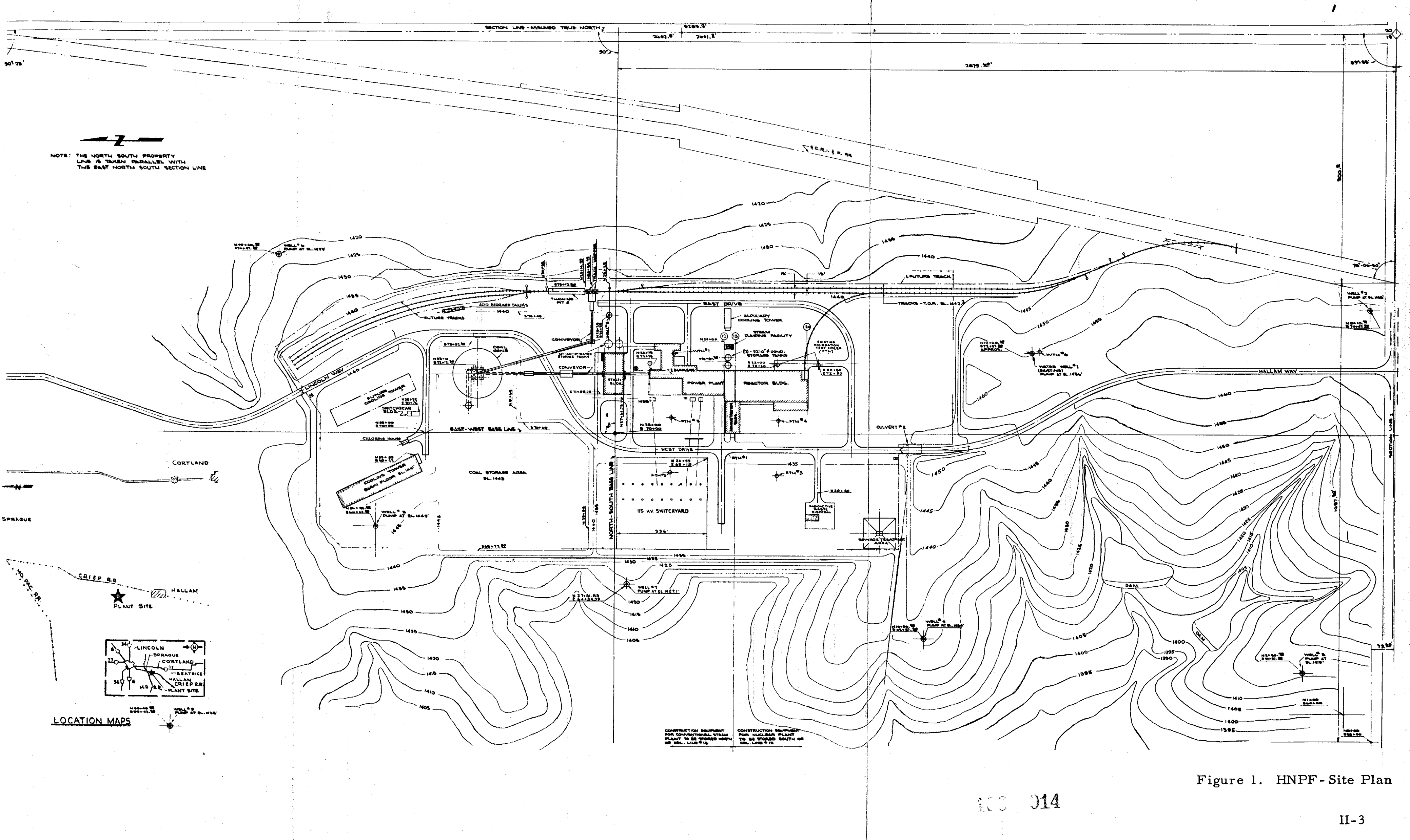



-9
$\vdots$
0
0
0
0
0
0

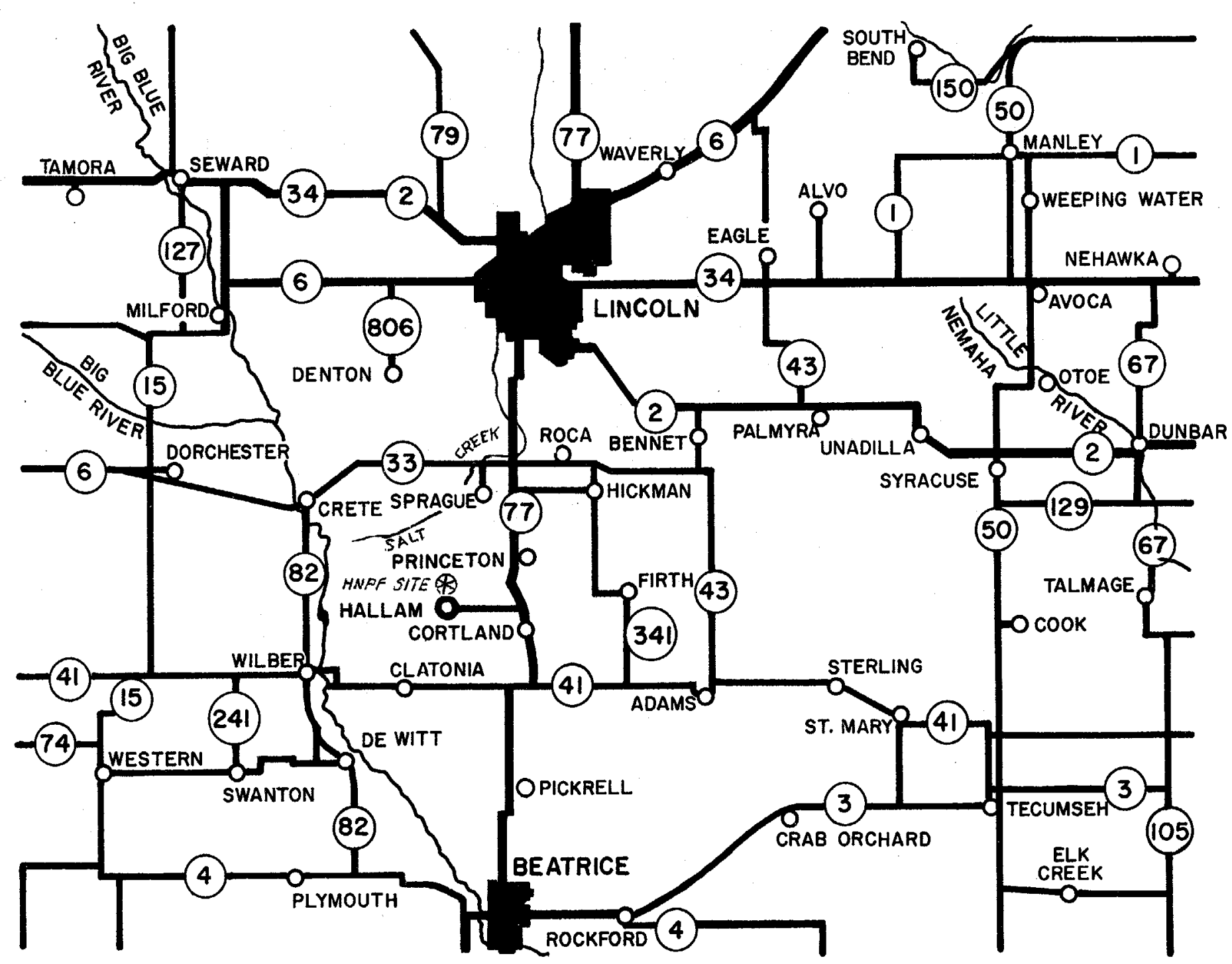

Fig. 3. Map of HNPF Area 
population 115,000, and Beatrice ( 19 miles south), population 13,000. The average rural population density in the vicinity of the plant is shown in Figure 4. Total population figures are listed in Table I (population figures given are from the 1950 Census).

\section{TABLE I}

POPULATION DENSITY SUMMARY

\begin{tabular}{cc}
\hline $\begin{array}{c}\text { Radius } \\
\text { from Reactor Site } \\
\text { (miles) }\end{array}$ & Population \\
\hline 0.5 & 0 \\
1.0 & 21 \\
5 & 1052 \\
10 & 6768 \\
\hline
\end{tabular}

\section{CLIMA TOLOGY}

The climate in the Hallam area is subject to a wide seasonal range in tem perature. Light rainfall, hot summers, and severe winters are typical for the area. Average maximum summer temperatures are generally 80 to $90^{\circ} \mathrm{F}$, but readings of 100 to $110^{\circ} \mathrm{F}$ may be expected for a few days each year. The mean daily temperature for June, July, and August is $75^{\circ} \mathrm{F}$. During the months of December, January and February the mean daily temperature is $25^{\circ} \mathrm{F}$. A temperature of $0^{\circ} \mathrm{F}$ or below may be expected for approximately 10 days each winter, with a minus $29^{\circ} \mathrm{F}$ being the lowest recorded temperature for that area.

\section{METEOROLOGY}

In the general area of the site the prevailing winds are from the northwest during the winter months, and from the southeast during the summer months. Table II is included to indicate the direction and average velocity of the winds as recorded at Lincoln Municipal Airport; Table III shows the direction and mean velocity for high altitude winds in the area. No large diurnal variation exists in either the direction or speed of the winds. Further meteorological data, including wind roses, are given in Figures 5 and 6 , and Table IV. The yearly wind rose data indicate that the prevailing wind directions are such that, on the average, 


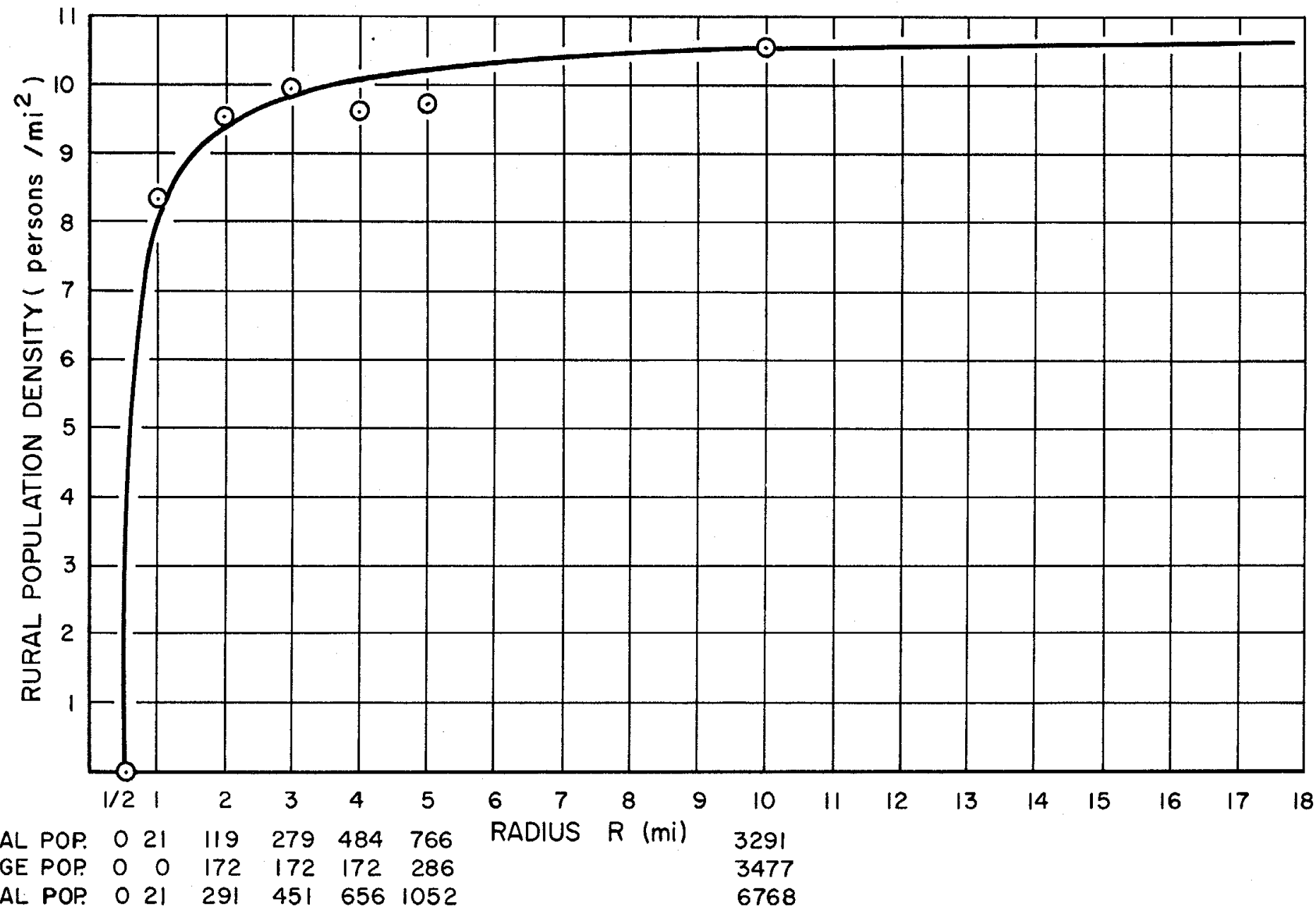

Figure 4. Average Rural-Population Density in the Vicinity of the HNPF Site 
TAB LE II

HOURLY AVER AGE WIND VELOCITY FOR PERCENT

OF YEAR FOR LINCOLN, NEBRASKA

\begin{tabular}{|c|c|c|c|c|}
\hline \multirow[b]{2}{*}{ Direction } & \multicolumn{4}{|c|}{ Velocity ( $\mathrm{mph}$ ) } \\
\hline & 0 to 10 & 11 to 20 & 21 to 30 & 31 to 40 \\
\hline $\mathbf{N}$ & 5.2 & 3.0 & 0.7 & 0.1 \\
\hline NNE & 2.4 & 2.1 & 0.5 & 0.05 \\
\hline $\mathrm{NE}$ & 2.7 & 1.5 & 0.2 & 0.1 \\
\hline ENE & 2.1 & 1.1 & 0.2 & 0.1 \\
\hline $\mathbf{E}$ & 2.8 & 0.9 & 0.1 & 0.01 \\
\hline ESE & 2.1 & 1.9 & 0.2 & 0.04 \\
\hline $\mathbf{S E}$ & 6.3 & 3.0 & 0.5 & 0.1 \\
\hline SSE & 4.4 & 3.0 & 0.8 & 0.1 \\
\hline $\mathbf{S}$ & 5.0 & 3.0 & 0.9 & 0.2 \\
\hline SSW & 2.4 & 2.6 & 0.6 & 0.1 \\
\hline $\mathbf{S W}$ & 2.4 & 1.5 & 0.2 & 0.05 \\
\hline WSW & 1.5 & 0.9 & 0.1 & 0.02 \\
\hline$W$ & 1.7 & 0.8 & 0.2 & 0.1 \\
\hline WNW & 2.4 & 1.7 & 0.5 & 0.2 \\
\hline NW & 3.2 & 2.8 & 1.0 & 0.3 \\
\hline NNW & 4.1 & 4.0 & 1.9 & 0.3 \\
\hline
\end{tabular}

* Data from weather bureau, Lincoln Municipal Airport, Lincoln, Nebraska.

All figures represent five-year average, 1939-1943. 
TABLE III

SEASONAL MEAN WINDS FOR HIGH ALTITUDE AT LINCOLN, NEBRASKA*

\begin{tabular}{|c|c|c|c|c|}
\hline Altitude $(\mathrm{ft})$ & Winter & Spring & Summer & Fall \\
\hline 10,000 & $285 / 23-23$ & $284 / 18-20$ & $282 / 11-15$ & $280 / 16-19$ \\
\hline 20,000 & $294 / 36-30$ & $287 / 35-28$ & $284 / 17-20$ & $286 / 26-27$ \\
\hline 30,000 & $281 / 63-45$ & $278 / 48-44$ & $280 / 25-28$ & $279 / 40-37$ \\
\hline 40,000 & $283 / 76-38$ & $276 / 55-38$ & $286 / 29-27$ & $274 / 44-34$ \\
\hline 50,000 & $279 / 50-25$ & $273 / 39-24$ & $269 / 23-19$ & $269 / 40-23$ \\
\hline
\end{tabular}

* Direction/velocity (knots) - direction standard deviation 


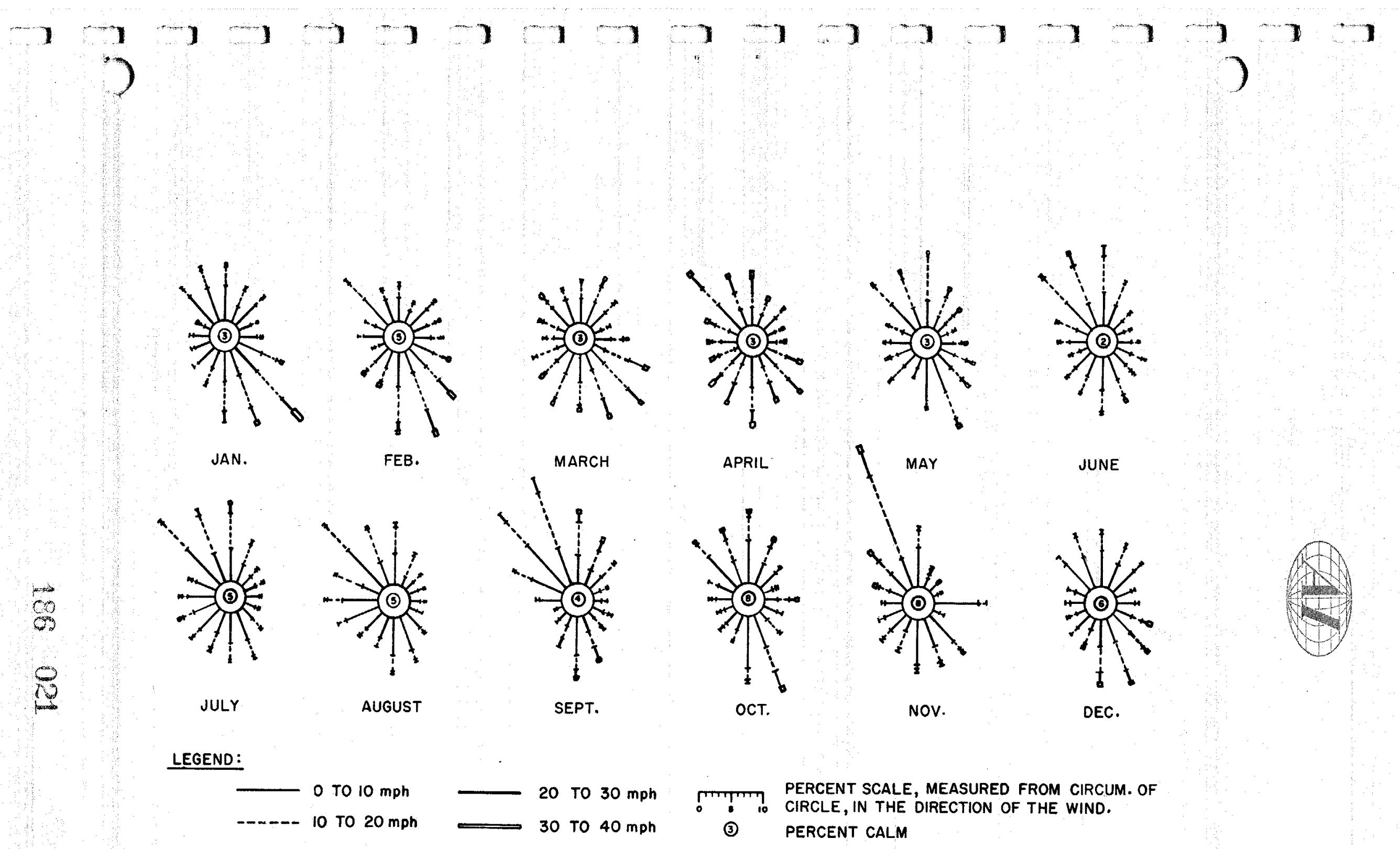

Figure 5. Monthly Wind-Rose Data (5-yr average) 


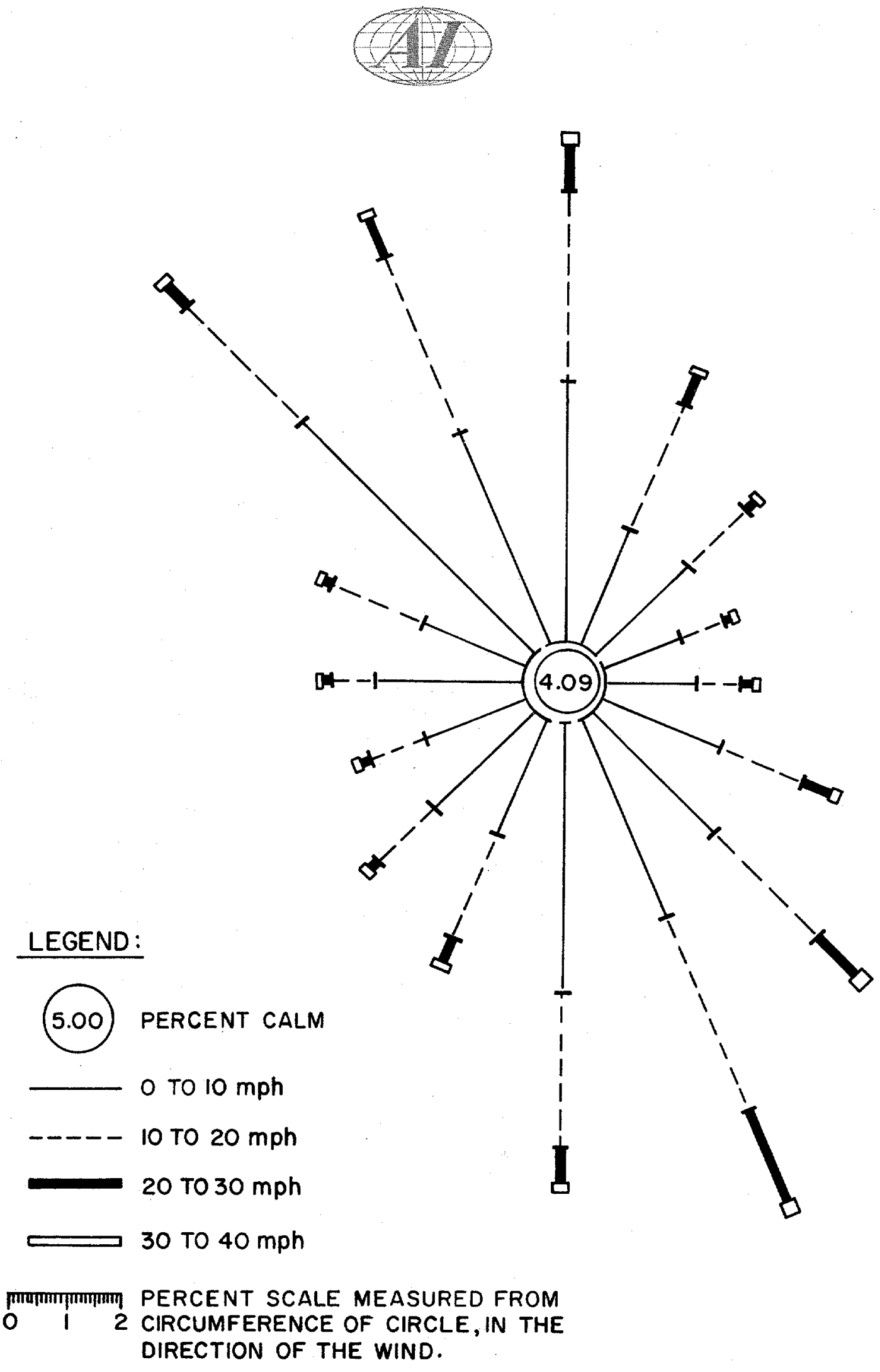

Figure 6. Yearly Wind-Rose Data (5-yr average) 


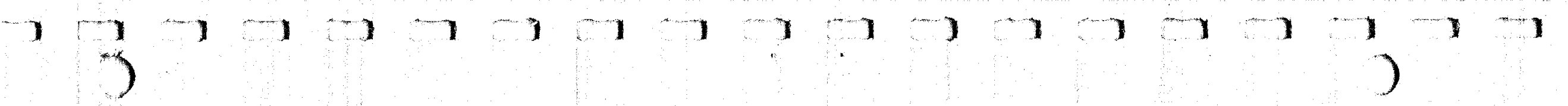

\section{TABLE IV}

METEOROLOGICAL DATA FOR LINCOLN, NEBRASKA

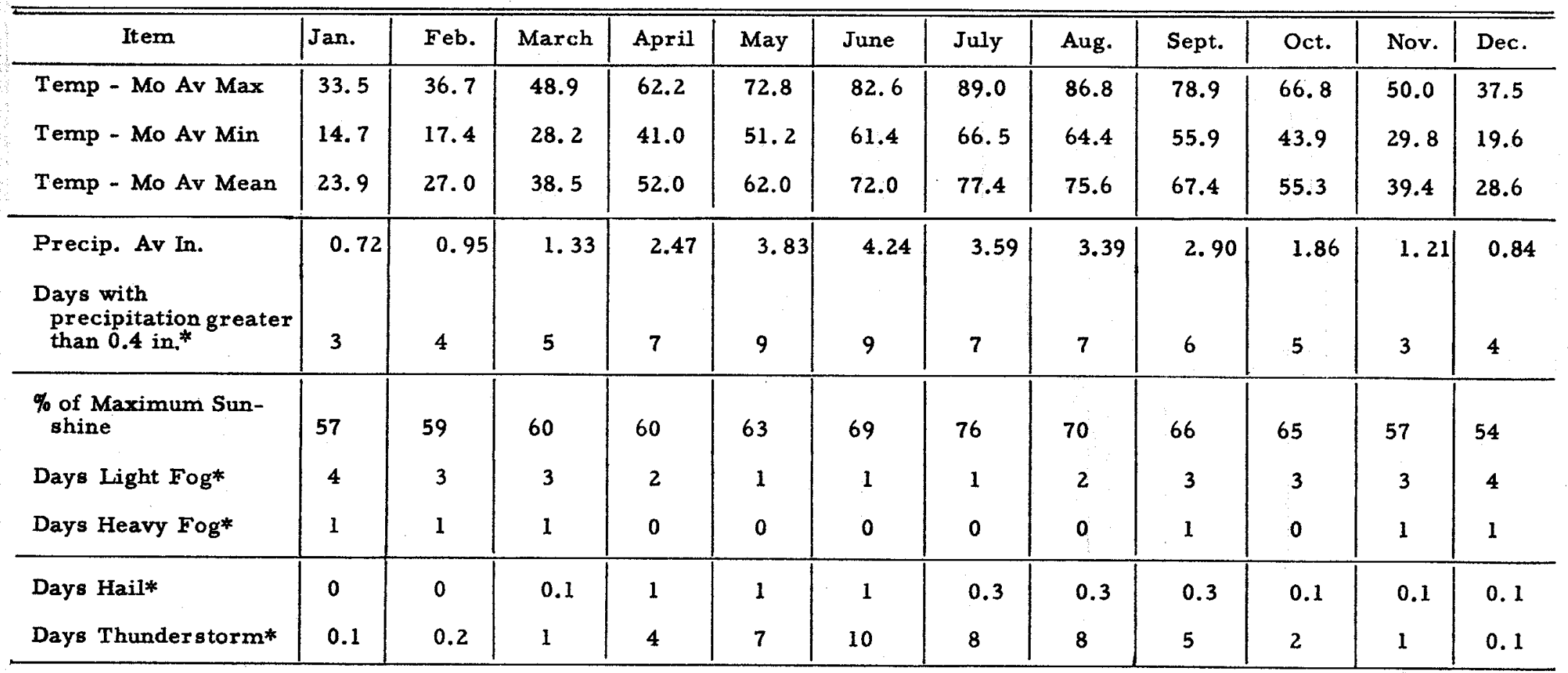

* Average number of days per month the event occurred. 


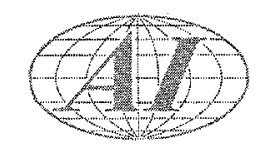

Lincoln is exposed to winds from the direction of the site $5.5 \%$ of the year, Crete $4.3 \%$ of the year, and Beatrice $8 \%$ of the year.

Nebraska may be considered to be on the western edge of the tornado belt which extends northward from the Gulf of Mexico. Since tornadoes do not travel in predictable paths nor reach ground level in any established locations, damage from tornadoes is considered to be a purely random event with extremely low frequency.

\section{E. SEISMOLOGY}

The Hallam area of southeast Nebraska is located in Zone 1 of the Uniform Building Code map of seismic probability. Zone 1 is defined as an area where infrequent seismic disturbances may be expected to cause only minor damage. This classification is substantiated by information obtained from the United States Department of Commerce, Coast and Geodetic Survey, which shows that in 1877 and 1935 tremors having intensities of six to seven (Rossi-Forel scale of intensities) ${ }^{*}$ caused minor damage to towns in the general area (Figure 7 ).

\section{F. HYDROLOGY}

The average rainfall at the site is $27.51 \mathrm{in./yr}$. Light rains are to be expected during the winter months, when an average of $28.7 \mathrm{in.}$ of snow also falls. Summer precipitation, generally in the form of thunderstorms and hailstorms, averages slightly less than $4 \mathrm{in}$./month for the 5 summer months, May through September.

The reactor site is on relatively high ground on the northeast slope of the divide separating the watersheds of the Big Blue River, Salt Creek, and the north fork of the Nemaha River. Contours (Figure 2) indicate the drainage systems in the immediate area. Drainage from section 19 flows into Salt Creek and thence northward to the Platte River, with a corresponding elevation drop of approximately $300 \mathrm{ft}$. A large retention dam (Figure 2) and proper diversion

\footnotetext{
* 6. FAIRLY STRONG SHOCK - General awakening of those asleep; general ringing of bells; oscillation of chandeliers; stopping of clocks; visible agitation of trees and shrubs; some startled persons leaving their dwellings.

7. STRONG SHOCK - Overthrow of movable objects; fall of plaster, ringing of church bells; general panic, without damage to buildings.
} 

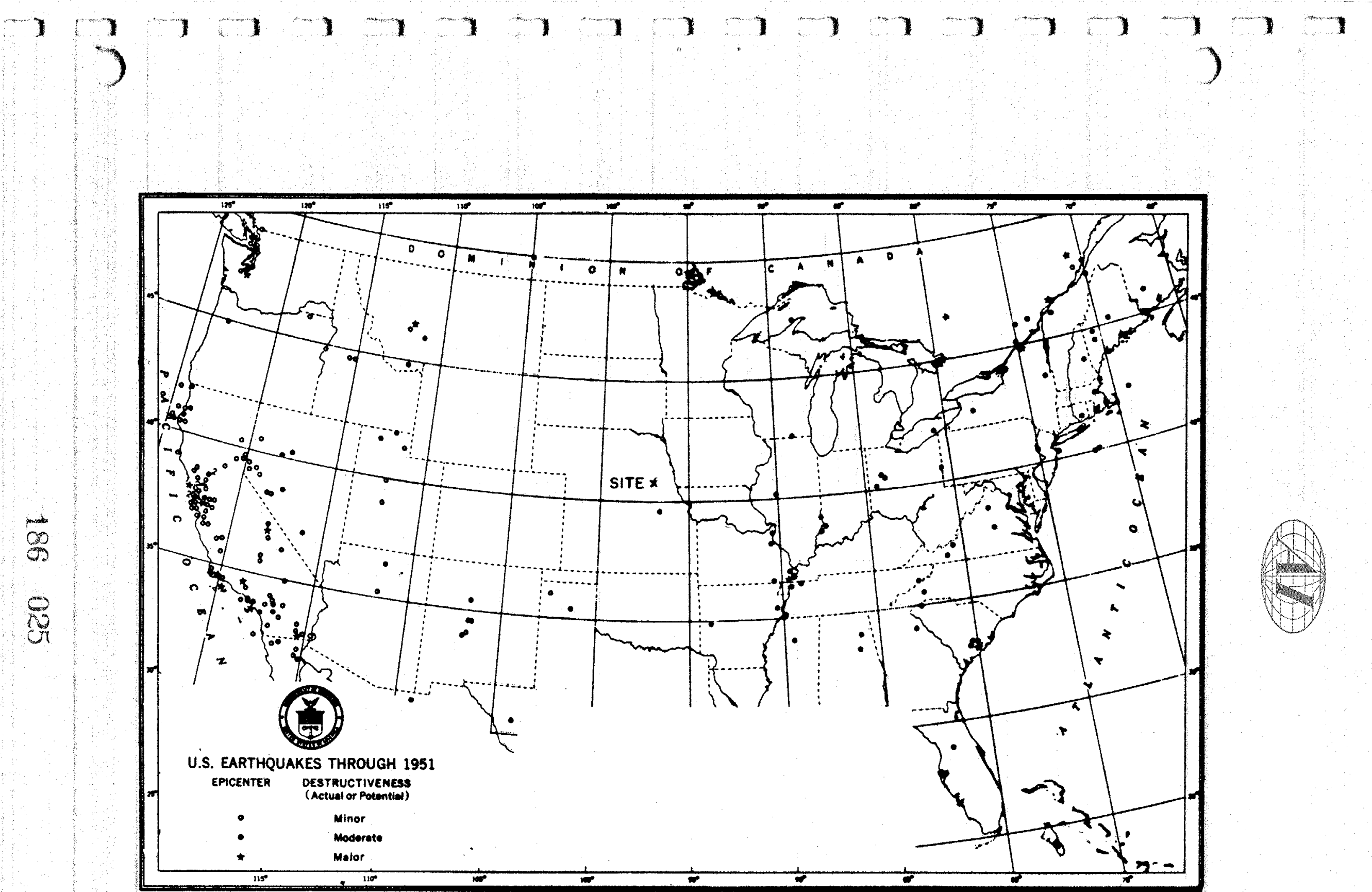

Figure 7. Map of the United States Showing Epicenter and the Relative Destructiveness of Earthquakes through 1951 


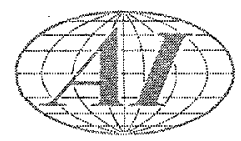

practices assure adequate control of surface waters. The State of Nebraska Department of Health believes that there are no persons, communities, or indus tries using any of the streams draining from the reactor site for either domestic or industrial purposes for approximately 250 miles down stream of the site. The entire area south and southwest of Lincoln represents a watershed development area where active soil and water conservation practices are being carried out. Field terracing and small dams are being constructed by the farm owners. Recent federal aid has permitted a significant acceleration of this conservation program.

With the exception of a few unimportant wells within the city limits, Lincoln's water supply is provided by wells at Ashland, Nebraska, approximately 25 miles to the northeast. Therefore, the primary water source for Lincoln is some 40 to 45 miles northeast of the proposed site. The water is taken from wells deep enough to make it extremely unlikely that surface waters could represent a potential contaminant. This same pattern of supplying water from the wells is used by small villages, unincorporated settlements, and the majority of the farm homes throughout this portion of the state.

Underground water is available in this area at a depth of some $200 \mathrm{ft}$. The water is contained in a gravel bed overlaying limestone bedrock forming an underground stream which flows in the east-southeast direction. Lying above this underground stream is a $200-\mathrm{ft}$-thick layer of glacial clay. Soil reports indicate this clay to be very stiff, with high plasticity, and with an unconfined compressive strength estimated at 8000 to $9000 \mathrm{lb} / \mathrm{ft}^{2}$. This layer represents an extensive volume which is available for absorbing surface waters. Surface water held by the retention dam would be expected to infiltrate this absorbing material at a very slow rate with insignificant carryoff in a lateral direction due to lack of hydrostatic pressure. The underground streams flow at an estimated velocity of $300 \mathrm{ft} / \mathrm{yr}$ so that it requires some $17 \mathrm{yr}$ for the water to move one mile. Recent age determinations, based on the tritium content, indicate that the age of the underground water is in excess of $50 \mathrm{yr}$. This demonstrates the poor communication between surface and sub-surface water flows. 


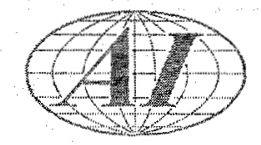

\section{BUILDING}

The reactor building (Figures $8,9,10$, and 11) houses the reactor, the heat transfer system, reactor service systems and equipment, and miscellaneous maintenance and service areas. The building design conforms to all applicable building codes. The building is of steel frame construction with a roof of steel decking over steel purlins insulated with 2 in. of rigid incombustible material. The exterior walls are covered with insulated steel panels joined to form a reasonably tight enclosure.

The largest section of the building is the high-bay area which is approximately $278 \mathrm{ft}$ long, $85 \mathrm{ft}$ wide, and $75 \mathrm{ft}$ high. In shielded compartments beneath the highbay floor are the sodium graphite reactor, the radioactive portion of the sodium heat transfer system, fuel cleaning and storage facilities, the maintenance cell, and piping and service equipment. To facilitate the delivery of heavy components, a railroad spur track enters the high-bay area at the south end of the building. Alow-bay area, which houses process service systems, runs along the east side of the building. The tank-car sodium-melt station is adjacent to the railroad spur, at the south end of the low-bay area.

The steam generators and associated components of the non radioactive portion of the sodium heat transfer system are housed in three separate enclosures at the north end of the high-bay area (Figures 9 and 11). The high-bay bridge crane has coverage over the ceilings of the steam generator rooms.

The control room and electrical equipment area are located at the north end of the reactor building, between the steam generator rooms and the conventional fossil-fired plant.

A lead-shielded fuel handling cask, $53.5 \mathrm{ft}$ high and weighing approximately 200 tons, is mounted on a gantry which operates in the reactor room between the reactor and the fuel cleaning and storage area. The control rod drive mechanisms are mounted on an integral movable support structure. The drive mechanisms can be disconnected from the control rods at the upper surface of the reactor loading face shield and the entire assembly can be moved away, leaving the shield face clear for fuel handling operations. 


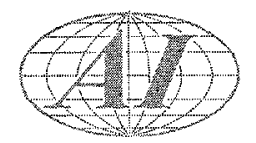

REACTOR CORE COMPONENT, STORAGE AND SERVICE CELLS

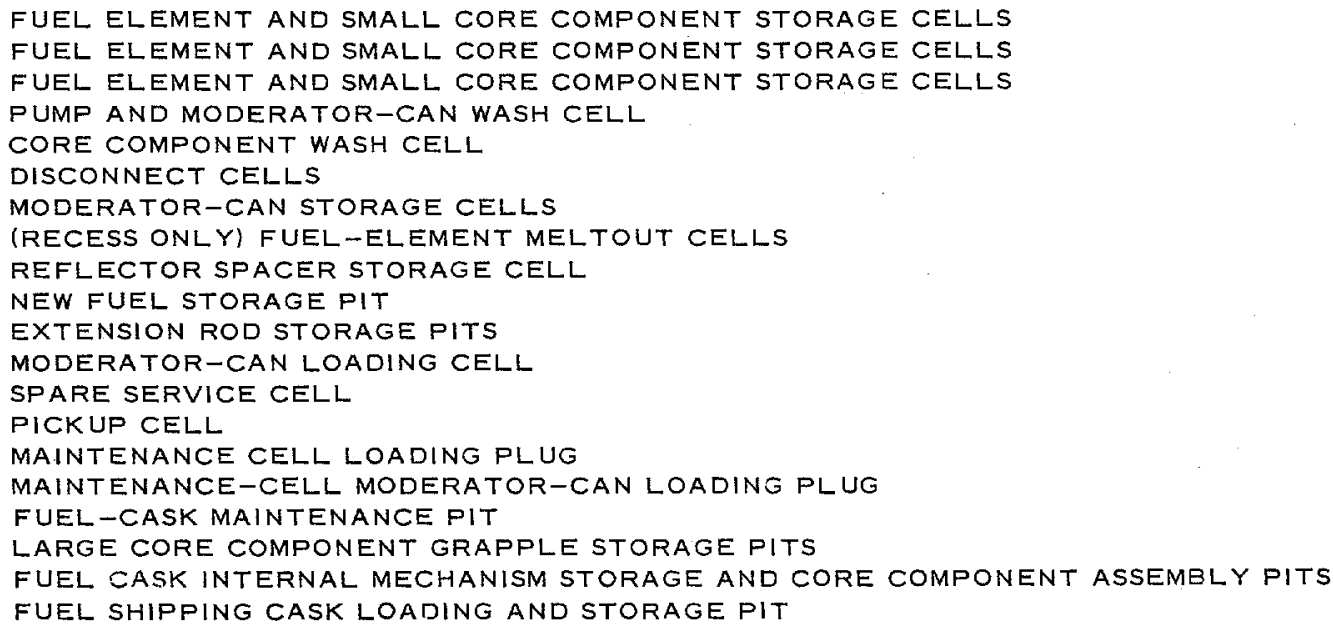

REACTOR PITS

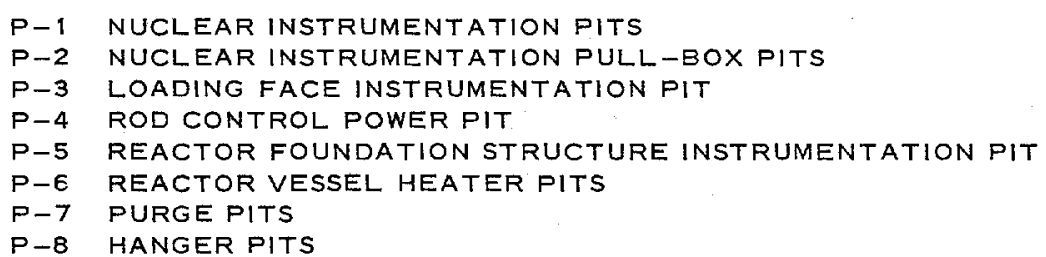

SHIELD PLUGS AND HATCHES
TRENCHES

T-1 ORGANIC COOLING PIPE

$T-2$ ORGANIC COOLING PIPE

T-3 CAVITY LINER COOLING

T-4 CAVITY LINER COOLING

T-5 CAVITY LINER COOLING

ELECTRICAL EQUIPMENTS

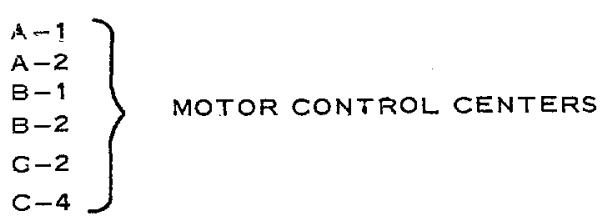

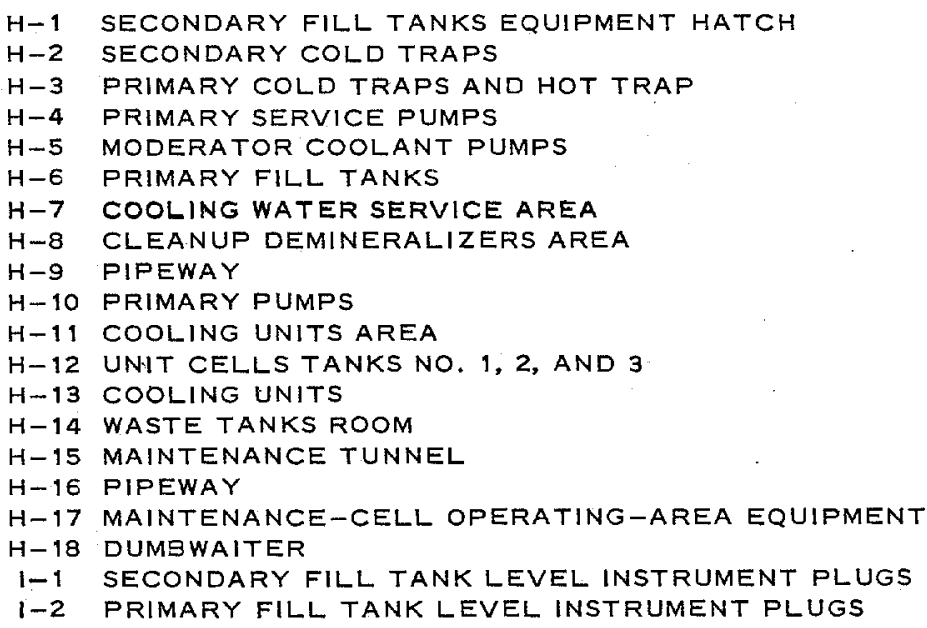

Figure 9. Reactor-Building-Layout Plan below Elevation of $1460 \mathrm{ft}$ (Sheet 1 of 2) 


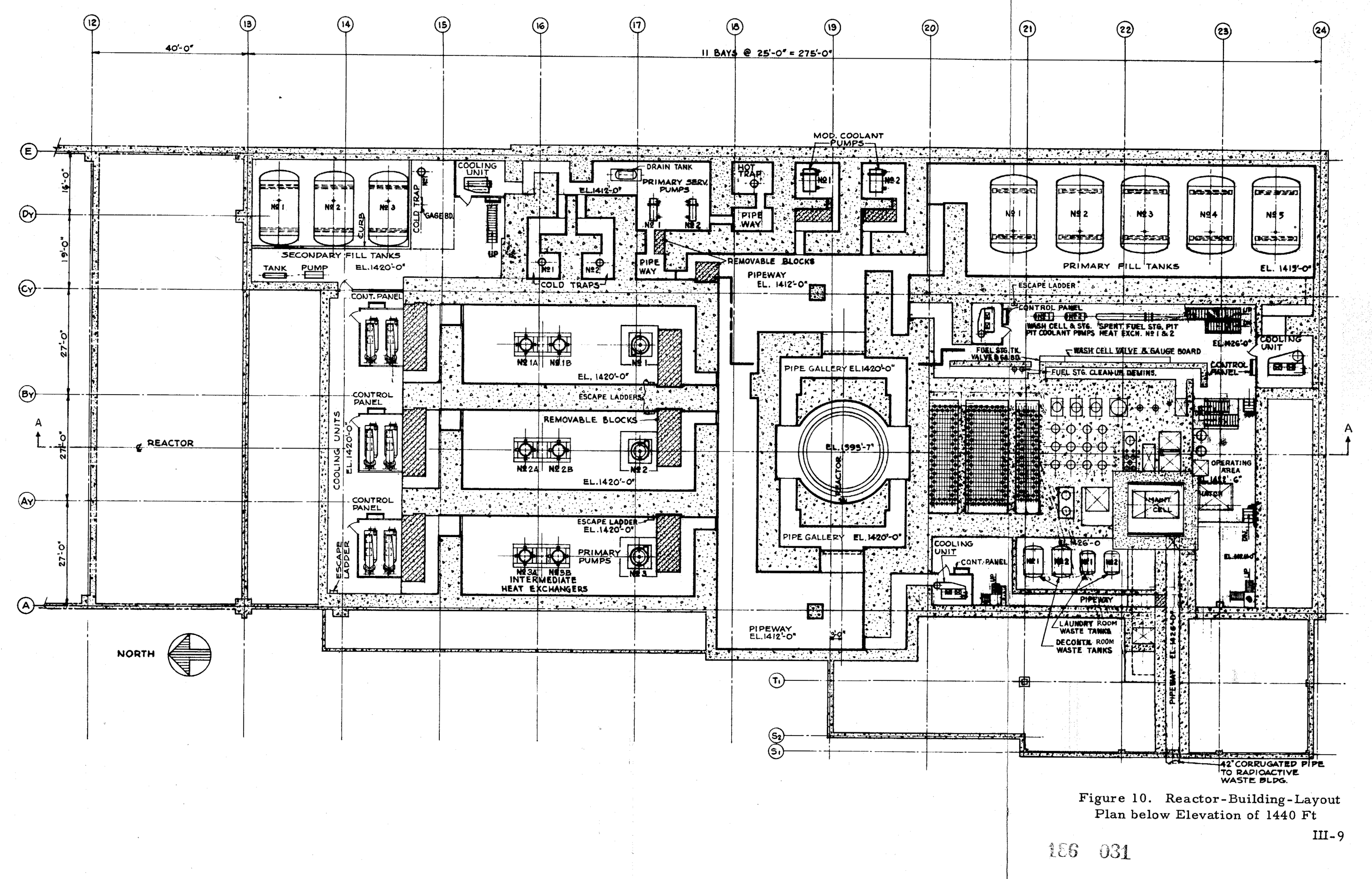




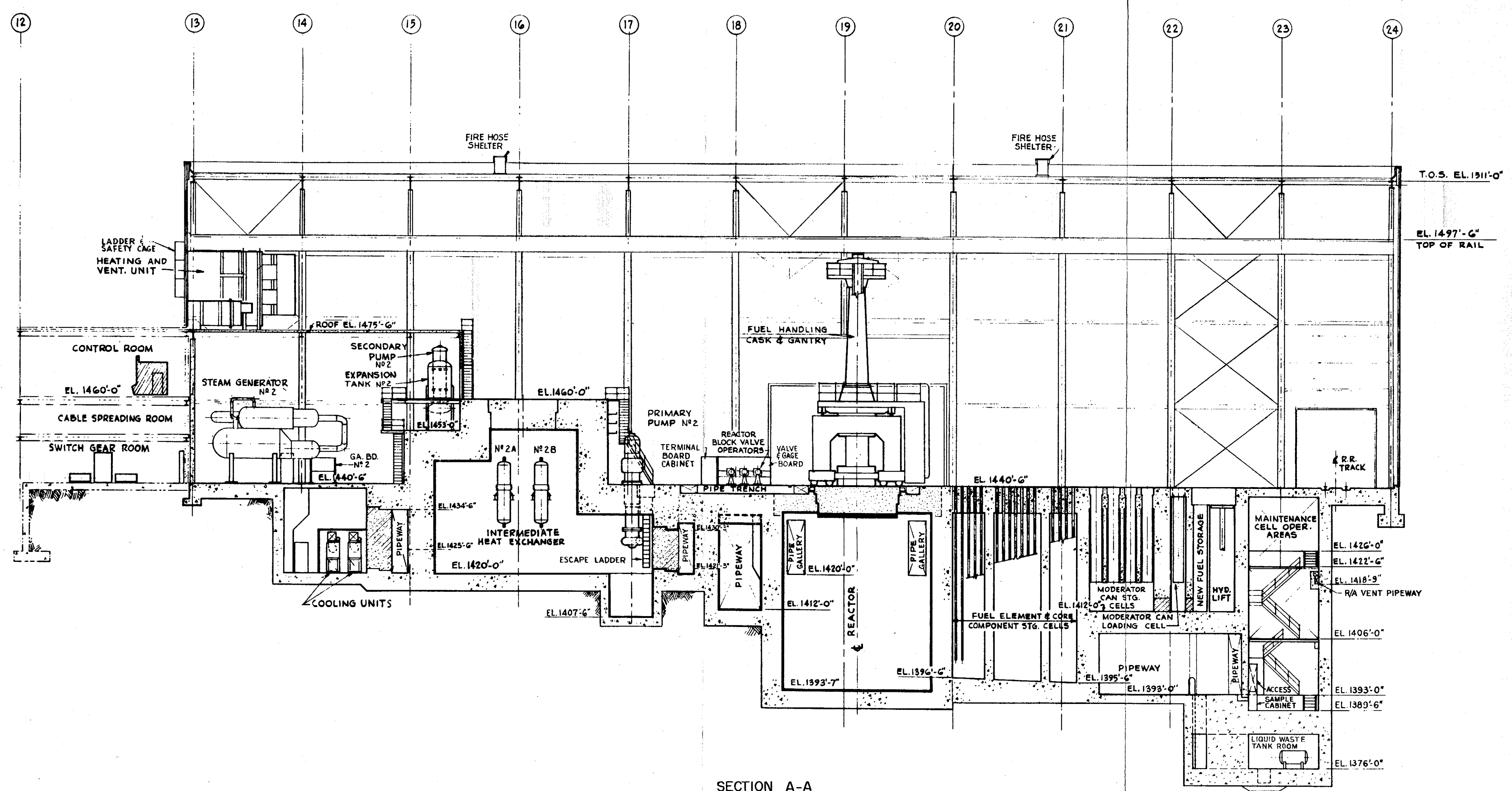


All piping and equipment which handle radioactive material are located in shielded cells below grade. The three intermediate heat exchanger (radioactive sodium - nonradioactive sodium) cells are individually shielded. The shielding walls of the pipe tunnels and cells are of ordinary concrete. High-density concrete is used in the reactor loading face shield, maintenance cell operating faces, and a few other areas. A nitrogen atmosphere is maintained in all the cells to exclude air from the piping and components which contain radioactive sodium, thus reducing the fire hazard in the event of a sodium leak. The cells are lined with steel plate to provide confinement, to minimize nitrogen leakage, and to keep water out. The concrete hatch plugs which provide access to the primary pipe galleries and cells are sealed to prevent leakage and stepped to prevent radiation streaming.

\section{A. BUILDING VENTILATION}

The reactor building ventilation system is designed to satisfy general heating and ventilation requirements for personnel comfort and to minimize the possibility of contaminating the entire plant as a result of an incident in which radioactivity is released to the air. The design objective with respect to confinement of the building atmosphere is to maintain a negative pressure (relative to outdoor barometric pressure) to insure that leakage of air is inward toward potentially radioactive areas.

Most areas of the building are continuously supplied with filtered and tempered air on a once-through basis from a central, comfort heating system. The air is then filtered for particulate matter, and released to the atmosphere through the building vent stack. In the control room, viewing gallery, counting room, and amplifier areas the room air is maintained at a constant pressure slightly above outdoor barometric pressure, at a constant $70^{\circ} \mathrm{F}$ temperature and at a maximum relative humidity of $50 \%$ by means of unit type air conditioning systems. In certain service areas, such as the auxiliary bay, steam generator rooms, and the battery room, the air is supplied from a central comfort heating system but is exhausted directly to atmosphere.

The ventilating rate requirements throughout the building vary from two volume changes of outside air per hour in the reactor room to 20 changes per hour in such areas as the laundry and the battery room. 


\section{(4i)}

To minimize the chances of spreading airborne contamination, pressure differentials within the building are maintained so that the flow of air is toward areas more likely to become contaminated. Clean areas, such as the control room, in which no contamination is anticipated, are maintained at plus 1/8-in. $\mathrm{H}_{2} \mathrm{O}$ pressure with respect to atmospheric pressure. Areas in which no contamination is expected, but where the possibility exists, are maintained at pressures varying from atmospheric pressure to $1 / 4$-in. $\mathrm{H}_{2} \mathrm{O}$ below atmospheric pressure, depending on the probability of contamination. The maintenance cell described below is normally contaminated, and is kept at $1 / 2-$ to 3/8-in. $\mathrm{H}_{2} \mathrm{O}$ below atmospheric pressure.

An integrated differential pressure control system automatically regulates the static pressure and the volume change rate of ventilation air in each area. Motorized dampers control the flow of air in both supply and exhaust branches. The dampers are operated by proportioning controllers equipped with pressure piping open to the room atmosphere and reference piping open to the outside atmosphere.

Building exhaust through the stack is continuous at all times. This is insured by having $100 \%$ spare exhaust fan equipment. The normal and spare fans are supplied from the diesel generator unit in the event of a power failure. All effluent is filtered for removal of particulate matter, and the stack is provided with a radiation detection and alarm system.

\section{B. MAINTENANCE CELL}

A maintenance cell, located at the south end of the fuel storage area below the reactor room floor level provides for maintenance and inspection of radioactive core components. The cell is shielded and equipped for remote handling and viewing. Core components are lowered into the cell through openings provided in the top. Tools used in the cell can be removed for decontamination through a handling tunnel which adjoins the cell and runs under the reactor room floor to an opening in the floor of the decontamination room. With this arrangement the reactor room is not exposed to contamination from the cell interior.

The operating area for the cell has operating stations at three levels. A window is installed at each station, making an entire in-cell component (e.g., fuel element) visible. Manipulators and crane facilities are installed in the cell 


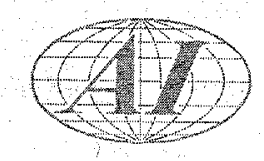

to give maximum handling capabilities. Additional in-cell equipment includes a special mechanism for disconpecting fuel shield plug and hanger assemblies from the fuel cluster, and miscellaneous tools such as wrenches, saws, drills, fixtures, and gauges.

The maintenance cell is designed to allow visual inspection and minor maintenance of fuel elements, control rods, and moderator cans. The most common operations, for which allowances have been included in the cell design, are the preparation of spent fuel elements for shipping, and the replacement of control rod absorber ring assemblies and thermocouples.

The core components are transferred from the reactor to the maintenance cell by the fuel handling cask. Fuel elements are moved as complete assemblies, including hanger rod and top shield plug.

The three sides and the floor of the cell are composed of ordinary concrete; the operating face and roof are composed of dense concrete using magnetite iron ore as the aggregate. The interior of the cell is lined with carbon steel plate, welded to produce a gas tight enclosure and painted with acid-resistant material to facilitate decontamination. Cell services will include water and steam which may be used during decontamination. Remote means can reduce contamination to permit personnel entry into the cell if required. A drain leading to the radioactive liquid waste system is provided in the cell floor to carry away wash water and other liquids. All effluent liquids from the maintenance cell are handled by the radioactive liquid waste system.

Maintenance operations require that the cell be provided with both air ventilation and inert gas atmosphere systems. When the cell ports are opened, or when operations involve minimum fire and radiation hazards, the air ventilation system is used. The air system is designed to maintain the cell atmosphere, with the cell ports closed, at approximately minus $3 / 8-i n$. $\mathrm{H}_{2} \mathrm{O}$ pressure with respect to outdoor atmosphere; or, with the ports open, to maintain an air flow into the cell through the openings at a minimum velocity of $100 \mathrm{ft} / \mathrm{min}$. When cell ports are closed, effluent air is exhausted to the radioactive vent system, where it is either passed directly to the building ventilation stack (after filtering to remove particulate matter) or is held up in the system decay tanks, depending on its monitored radioactivity level. When cell ports are open, air effluent is filtered and discharged directly to the stack. 


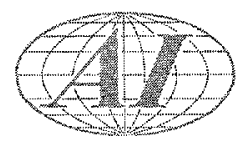

When irradiated fuel elements are handled in the cell, or when the operations involve a fire hazard, a nitrogen atmosphere is maintained in the cell. The nitrogen from the plant nitrogen system is supplied to the cell as needed to maintain the oxygen content of the cell atmosphere below $2 \%$ by volume, and to maintain cell pressure at minus 3/8-in. $\mathrm{H}_{2} \mathrm{O}$ with respect to outdoor atmosphere. The flow of nitrogen can be controlled automatically by an oxygen-analyzer flowcontroller system, or it can be controlled manually. Depending upon the monitored activity level, exhaust nitrogen is released from the cell through the radioactive vent system either to the decay tanks or to filters and the building stack.

\section{DECONTAMINATION ROOM}

The decontamination room can accommodate a main primary sodium pump, the largest component which may require decontamination. Other pieces of equipment likely to require decontamination are valves, hand tools, sample casks, respirators, and maintenance cell equipment. In the floor near one end of the room, a 4-ft square access plug can be removed, leaving an opening to the equipment tunnel which comes from the maintenance cell. The room is equipped with a 6-ton monorail hoist.

Equipment decontamination will generally be accomplished by steam cleaning or by sonic cleaning. The steam cleaning equipment consists of a wash pan and containment box for large components and a steam cabinet for smaller pieces of equipment. The sonic cleaner is a solvent bath which is vibrated at ultrasonic frequencies. The vibrations tend to loosen particles attached to any component immersed in the bath.

The wall and ceiling surfaces of the decontamination room are suitably painted, and the floor is covered with asphalt tile to facilitate cleaning. Sinks, shelves, and counters in the room are of stainless steel. Decontamination of the room itself may be accomplished with the steam cleaning equipment. All effluent liquid wastes from the decontamination room are handled by the radioactive liquid waste system.

The ventilation system for the decontamination room is designed to maintain a minus 1/4-in. $\mathrm{H}_{2} \mathrm{O}$ pressure with respect to atmospheric pressure when all doors to the room are closed. When the room is open to adjacent areas, the air 
flow is into the room through the doors from the reactor room and from the outside, and out of the room through the floor hatch which opens to the tunnel leading to the maintenance cell. If the maintenance cell is closed, the exhaust air from the decontamination room passes to the central exhaust system where it is filtered for particulate and discharged through the ventilation stack.

\section{FIRE PROTECTION SYSTEMS}

The fire protection systems throughout the plant are designed to combat the specific types of fires most likely to be encountered in any given area.

Fire protection outside of the building is provided by water hydrants and hose cabinets. Throughout the building various types and sizes of portable carbon dioxide and chemical applicators are provided. On the building roof, hose stations and portable extinguishing equipment are provided. In the vital electrical equipment areas, such as control room, amplifier equipment rooms, cable spreading room, steam generator room, diesel engine room, and the organic-coolant room, fixed pipe carbon dioxide extinguisher systems are provided. In non-sodium areas, such as portions of the auxiliary bay, the battery rooms, viewing galleries, ventilating equipment and decontamination equipment rooms, the change area, health-physics and counting rooms, cell cooling equipment rooms, and the radioactive liquid waste building, automatic sprinkler systems are provided. In the sodium areas beneath the reactor room floor, and in the maintenance cell, the nitrogen and helium atmospheres which provide operational inert gas blankets, also provide fire protection. A fixed pipe, dry nitrogen gas system protects the melt station area. Supplementary protection for these sodium areas and the melt station area is provided by Ansul fixed pipe dry chemical systems. In addition, these and all other sodium areas are provided with dry bulk calcium carbonate which can be applied to small sodium spills with hand shovels.

Fire detection and alarm instrumentation is installed throughout the plant to minimize the fire hazard. 


\section{THE REACTOR AND ASSOCIATED HEAT TRANSFER SYSTEM}

The HNPF reactor is sodium cooled, graphite moderated, and has a nominal output rating of $240 \mathrm{Mwt}$. This energy is removed from the core by the sodium heat transfer system and is used to generate steam which in turn drives an electric turbine-generator.

The reactor core consists of slightly enriched uranium-molybdenum fuel elements suspended between canned graphite moderator-reflector elements. The core assembly forms a right circular cylinder $17 \mathrm{ft}$ in diameter and $17 \mathrm{ft} \mathrm{high}$. The active fuel forms a matrix, $13-1 / 2 \mathrm{ft}$ in diameter by $13-1 / 2 \mathrm{ft}$ high, which is surrounded by a graphite reflector, $1-3 / 4 \mathrm{ft}$ thick. This assembly and its supporting structure are contained in a stainless steel reactor vessel which is surrounded by a thermal shield, a reactor outer vessel, thermal insulation, a gas-tight water-cooled cavity liner, and a concrete biological shield.

Three identical sodium heat transfer circuits carry the energy generated in the reactor core to the steam generators. Each circuit consists of a primary radioactive loop and a secondary nonradioactive loop connected through an intermediate heat exchanger. Steam from all three steam generators is fed into a common header which serves a single turbine-generator. The steam rate at the turbine throttle is $710,000 \mathrm{lb} / \mathrm{hr}$ at $800 \mathrm{psig}$ and $825^{\circ} \mathrm{F}$.

Reactor power level is regulated by a vertical control rod system made up of 13 shim-regulating rods and 15 safety rods. The rods consist of columns of boron-nickel rings suspended on steel pull-tubes. The safety rods are held by electromagnets and can be dropped into the core by de-energizing the magnets.

The plant is designed as a load-following system; that is, reactor power-level and sodium flow rates are varied according to steam demand. The reactor is equipped with a nine-channel nuclear instrumentation system for the power-level control system and the plant protective system. Sodium temperatures, pressures, liquid levels, and flow rates are measured in both primary and secondary sodium loops. Protective system instrumentation is provided throughout the reactor system to reduce power level and, if necessary, shut down the plant should a potentially dangerous condition arise.

Preliminary design features of the plant are listed in Table $V$. 


\section{TABLE V}

DESIGN FEATURES

\begin{tabular}{|c|c|}
\hline Reactor Nominal Rated Output & $240 \mathrm{Mwt}$ \\
\hline Reactox Design Rated Output & $254 \mathrm{Mwt}$ \\
\hline \multicolumn{2}{|l|}{ Reactor Core } \\
\hline Cavity depth & $46 \mathrm{ft}$ \\
\hline Reactor vessel dimensions & $19 \mathrm{ft}$ dia by $33 \mathrm{ft}$ high \\
\hline Active core dimensions & $13.5 \mathrm{ft}$ dia by $13.5 \mathrm{ft}$ high \\
\hline \multicolumn{2}{|l|}{ Core Positions } \\
\hline fuel & 155 \\
\hline control rods & 28 \\
\hline neutron source & 1 \\
\hline sodium temperature measurement & 3 \\
\hline sodium level measurement & $2($ not in core $)$ \\
\hline dummy & 18 \\
\hline total & 205 \\
\hline \multicolumn{2}{|l|}{ Fuel element } \\
\hline type & 19-rod cluster \\
\hline fuel material & $\mathrm{U}-10 \%$ moly alloy \\
\hline cladding material & stainless steel \\
\hline over-all length & $20.5 \mathrm{ft}$ \\
\hline active length & $13.5 \mathrm{ft}$ \\
\hline fuel area* & 5 in. $^{2}$ \\
\hline weight* (fuel only) & $227 \mathrm{~kg}$ (uranium-molybdenum) \\
\hline \multicolumn{2}{|l|}{ Fuel inventory } \\
\hline U-Moly alloy * & $35,200 \mathrm{~kg}$ \\
\hline uranium* & $31,700 \mathrm{~kg}$ \\
\hline \multicolumn{2}{|l|}{ Moderator-reflector element } \\
\hline material & graphite \\
\hline sheath material & stainless steel \\
\hline sheath thickness & $0.016 \mathrm{in}$ \\
\hline number of elements & 141 \\
\hline configuration & hexagonal prism \\
\hline
\end{tabular}

* Tentative.

IV -2

$186-637 A$ 


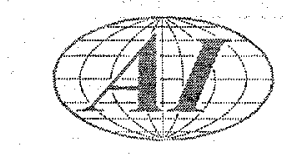

width across flats

length

sodium gap between elements

weight

Control rods

poison material*

number of shim-regulating rods*

number of safety rods*

rod speed*

Sodium Systems (full design power)

Flow rate per loop

Primary hot leg temperature

Primary cold leg temperature

Secondary hot leg temperature

Secondary cold leg temperature
16 in.

$17 \mathrm{ft}$

0.160 in. (average)

$2400 \mathrm{Ib}$

boron-nickel

13

15

$13.5 \mathrm{in.} / \mathrm{min}$

$2.82 \times 10^{6} \mathrm{lb} / \mathrm{hr}$

$945^{\circ} \mathrm{F}$

$607^{\circ} \mathrm{F}$

$895^{\circ} \mathrm{F}$

$557^{\circ} \mathrm{F}$

* Tentative.

\section{A. REACTOR}

The reactor core, which is shown in outline in Figure 12, consists of slightly enriched, uranium-molybdenum fuel elements suspended in a closely packed array of canned hexagonal graphite moderator elements. The moderator elements are scalloped at the corners so that each three adjoining elements form a channel between them which runs axially through the core. The fuel elements and control rods are suspended in these channels; the main sodium flow through the core is upward through the fuel element channels. The control rod thimbles are supported and sealed at the reactor loading face shield and extend downward approximately $38 \mathrm{ft}$ to the bottom of the core.

The sodium inlet pipes enter the reactor cavity just above the top of the moderator cans and run downward to the lower part of the reactor vessel. The major portion of the sodium enters the lower plenum between the grid plate and the bottom of the reactor vessel and then flows upward through the fuel element process tubes to the sodium pool above the core. This fluid removes the heat 


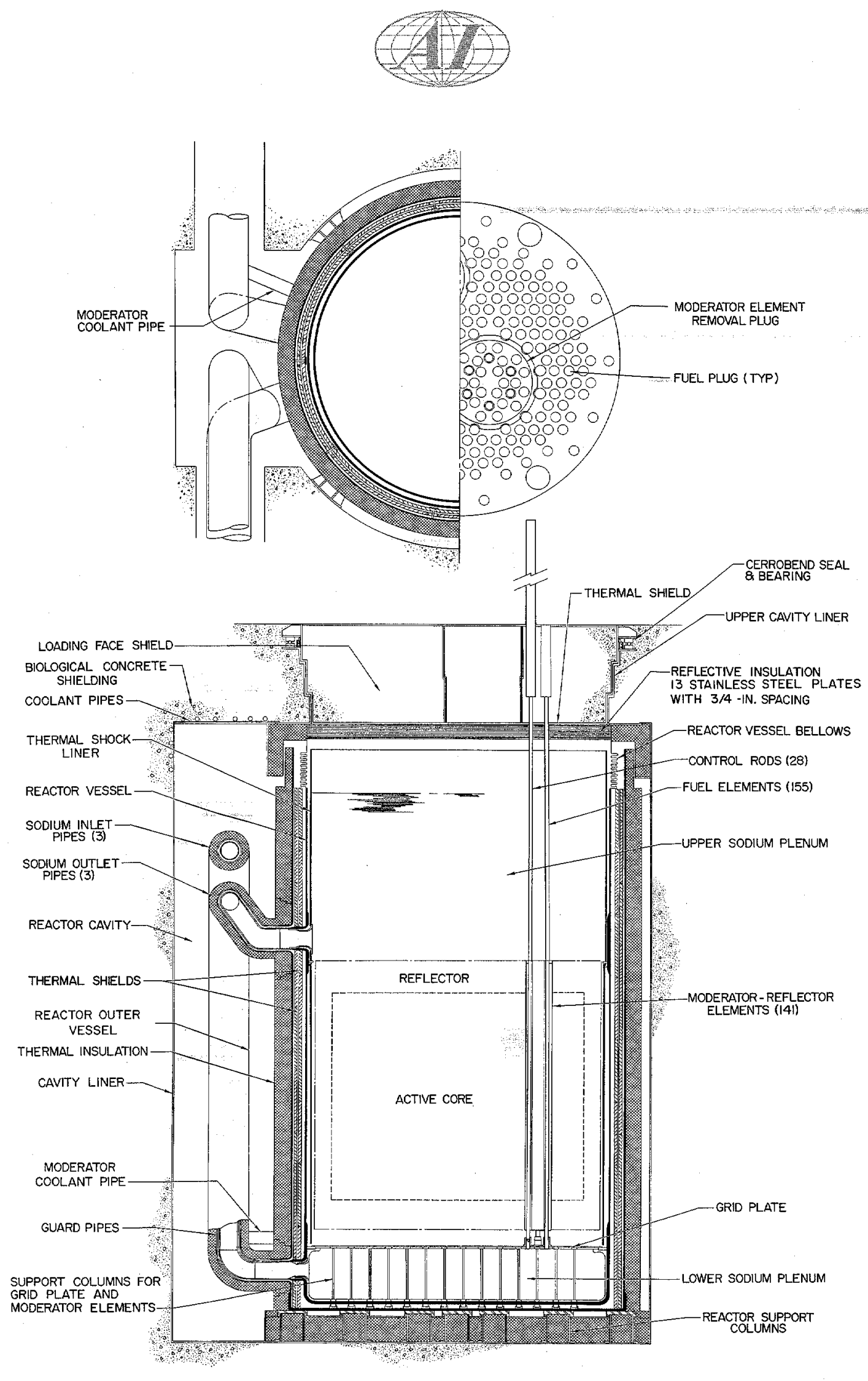

Figure 12. Reactor General Arrangement 


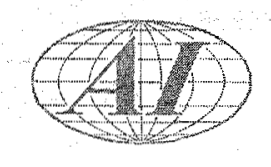

from the fuel elements. The remaining sodium ( 4 to $6 \%$ ) is routed by a parallel piping system to the plenum above the grid plate and then flows upward through the gaps between the moderator cans into the upper sodium pool. This sodium removes the heat generated in the moderator elements. The gap between moderator elements is nominally $0.160 \mathrm{in}$. wide and is maintained by spacer fittings which are fastened to the top heads of the cans.

Within the reactor cavity the sodium piping is double walled. The outer guard pipes extend from the reactor outer vessel to and including the blocking valves just outside of the reactor cavity. At their lower ends the guard pipes open into the reactor outer vessel. Any liquid sodium leaks interior to the blocking valves will be drained back to this outer vessel. Leak detectors and pumpout lines are provided. The outer vessel is sized so that with the addition of standby sodium inventory, a major sodium leak will not allow the sodium level to drop below the outlet nozzles of the primary pumps.

There are no openings into the reactor cavity below the upper surfaces of the core. The cavity is sized such that, in the event of a major disaster which dumps the primary system sodium including standby inventory into the cavity, the active core would remain flooded. No siphoning of sodium to a level below that of the upper surface of the core is possible since the lowest point in the primary sodium loop outside of the reactor cavity is at an elevation higher than the upper surface of the core.

The active core is a right circular cylinder, $13.5 \mathrm{ft}$ in diameter by $13.5 \mathrm{ft}$ high. It is enclosed by $1-3 / 4 \mathrm{ft}$ of reflector graphite, so that the total graphite assembly is $17 \mathrm{ft}$ in diameter by $17 \mathrm{ft}$ high. There are 141 moderator and reflector elements in the core. There is a total of 205 core positions: 155 for fuel elements, 28 for control rods, 1 for the neutron source, 3 for sodium temperature instrumentation, 2 for sodium level measurements above the core, and 18 spare channels which are filled with dummy elements when not in use.

The reactor fuel material is an alloy consisting of $10 \mathrm{w} / 0$ molybdenum in uranium. The alloy is enriched in $\mathrm{U}^{235}$ to $3.0 \mathrm{a} / 0$. The excess reactivity requirements are $2.5 \%$ for equilibrium xenon and samarium effects, $2.5 \%$ for

* Tentative. 


\section{(1i)}

fuel depletion, and $0.5 \%$ for control* It is expected that the average burnup will be 3,000 Mwd per tonne of uranium. Some of the more pertinent reactor characteristics are listed in Table VI.

\section{Fuel Elements}

The uranium-molybdenum fuel element shown in Figure 13 consists of a cluster of 19 fuel rods held vertically in a zirconium-alloy process tube. The fuel rods are suspended from an upper support and are held in position by a "spacing basket" consisting of the upper support and a series of spacers wired together and positioned approximately $1 \mathrm{ft}$ apart. For the purpose of shipping spent fuel, the fuel rods and spacing basket can be lifted out of the process tube as a single assembly.

\section{TABLE VI}

\section{REACTOR OPERATING DATA*}

Design rated output

Average thermal neutron flux

Axial flux (peak-to-average ratio)

Radial flux (peak-to-average ratio)

Initial conversion ratio

Power coefficient of reactivity (at full flow and power, core clean)

Excess reactivity (hot, clean)

Initial fuel enrichment

Average fuel burnup

Average specific power

Average power density
254 Mwt

$\sim 1 \times 10^{13} \mathrm{n} / \mathrm{cm}^{2}-\mathrm{sec}$

1.4

1.7

0.5

$-0.77 \times 10^{-5} / \mathrm{Mw}$

$5.5 \%$

$3 \mathrm{a} / \mathrm{o}$

3,000 Mwd/tonne U

$270 \mathrm{kw} / \mathrm{kg} \mathrm{U} \mathrm{U}^{235}$

$2.0 \mathrm{kw} / \mathrm{in}^{3}$

\section{* Tentative.}

Each fuel rod consists of the uranium-10w/o molybdenum fuel material in a column, 13-1/2 ft high by $0.579 \mathrm{in.}$ in diameter, enclosed in a thin-walled, stainless steel jacket. The jacket is 0.605 in. in interior diameter, and 0.010-in. in wall thickness. The 0.013-in. annular gap between the fuel material and the jacket is filled with NaK. A 1/2-in. layer of NaK covers the fuel material at the 

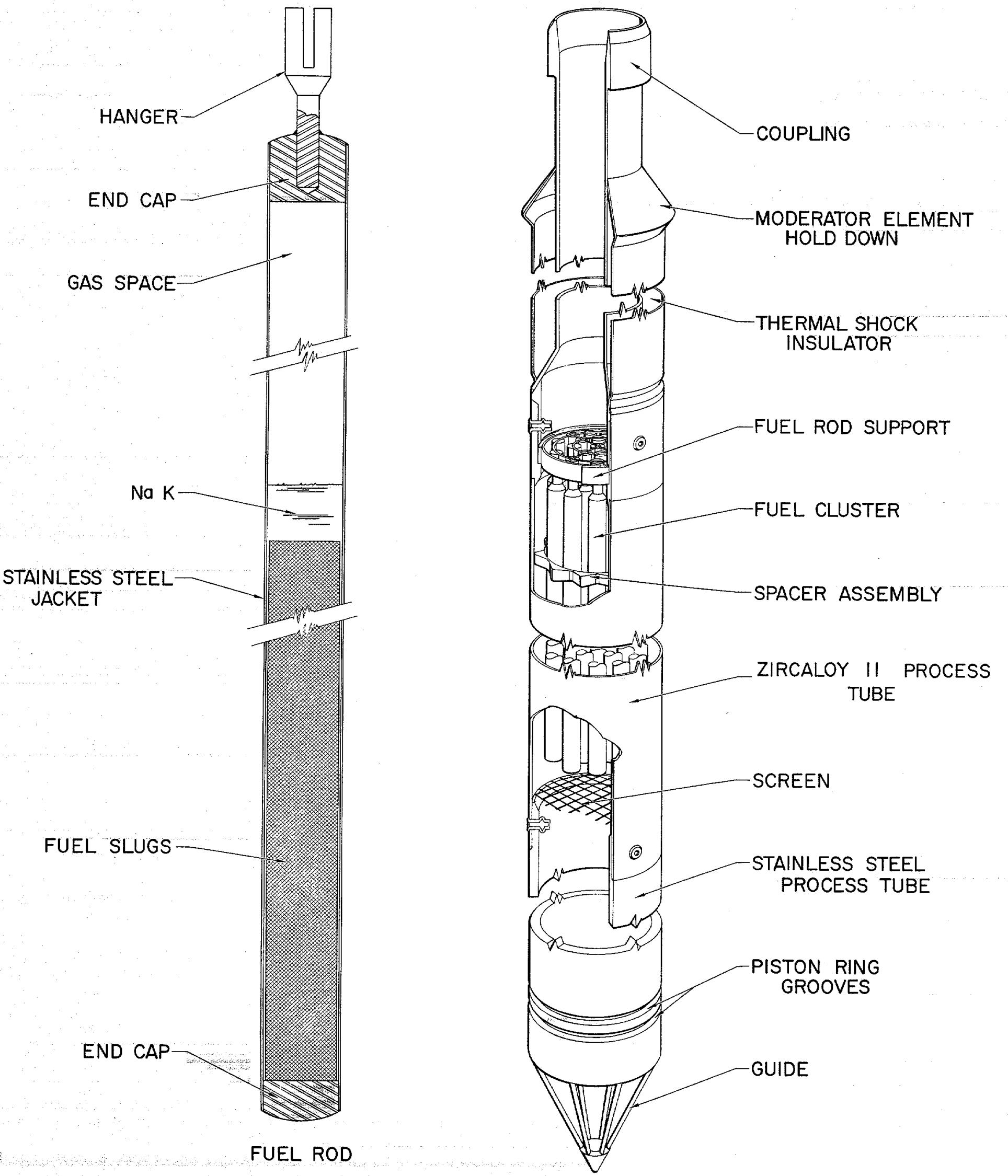

Figure 13. Fuel Element Assembly 


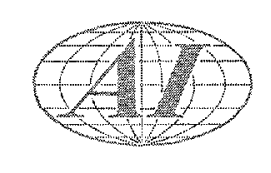

top, and above this a helium volume is provided to contain fission-product gases which might diffuse out of the fuel as it becomes irradiated. A structural backup to the rod in the vicinity of the gas space (not shown in Figure 13) is provided. The overall length of each fuel rod is approximately $15 \mathrm{ft}$.

Near the bottom of the fuel element, a steel end-section is fastened to the lower end of the process tube. Two piston rings mounted on the outside of the lower end-section form a seal in a fixed mating tube that extends up from the grid plate. The grid-plate tube directs the main sodium flow from the lower plenum into the process tube and up through the fuel rod cluster.

At the upper end of the fuel element, a steel section is similarly attached to the process tube. This upper section terminates in a ringcatch that matches the disconnect coupling of the hanger-rod assembly.

Each fuel element is suspended from a shield plug in the reactor loading face shield. The fuel element hanger rod is actually a continuation of the steel cylinder which forms the outer case of the shield plug. This support cylinder is provided with holes through which the sodium coolant is discharged from the fuel element process tube to the upper sodium plenum. A movable-plug variable orifice is provided in the upper section of each process tube to control sodium flow and thus to regulate fuel-channel outlet temperatures. The orifice plug-positioning mechanism and the leads for two thermocouples (to measure coolant temperature at the fuel-channel outlet) are brought out of the core through the fuel-element support cylinder. Each outlet temperature thermocouple is located in the sodium channel just above the fuel-rod cluster.

\section{Moderator and Reflector Elements}

The moderator and reflector elements (Figure 14) are graphite blocks canned in stainless steel. Each element is a prism of hexagonal cross section measuring 16 in. across the flats, and is scalloped at the corners. Elements are $17 \mathrm{ft}$ in length, and each one weighs $2400 \mathrm{lb}$. A total of 141 elements makes up the core graphite assembly. For those channels which open into the lower plenum, the corner scallops provide process channels through the core; for those channels that do not open into the lower plenum, reflector filler elements (having the same size as process tubes) fill the opening in order to eliminate large concentrations of sodium in these locations.

IV-8

186043 



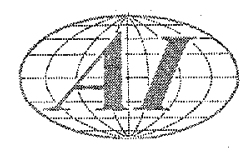

The graphite assembly in each element consists of three hexagonal blocks keyed together end to end to form a single hexagonal log. The sheath material which forms the sides of the can is type 304 stainless steel, 0.016 in. thick. The can is made up of six panels welded together lengthwise down the center of each of the six flats. The base of the element is a $1 / 2-i n$. -thick stainless steel casting and includes the 6-in.-high pedestal which supports the element on the bottom grid plate. The top head is also $1 / 2$-in. -thick stainless steel. Both the base and the headfit inside the sheath and are welded to the inside edge at the bottom and the top of the element, respectively. The thermal expansion of the stainless steel base and head is greater than that of the graphite. This causes the sheath to be pulled away from the graphite at the top and bottom of the element at high temperatures. To prevent excessive stresses in the sheath at the edges of the base and the head, both base and head are equipped with fingers, 4 in. long and about $1 / 2$ in. thick, which reach into the element along the inside of the can walls, fitting into machined slots in the graphite block. The fingers curve inward toward the graphite under the pressure of the sheath and support the sheath over its approximately 2-1/2 in. expanded region. Each head has 30 of these fingers, five per flat.

The elements are positioned at the bottom by individual seats in the bottom grid plate into which the element-supporting pedestals fit.

The 0.160-in. gap between cans is maintained by spacer fittings which are fastened to the top head of each element. The spacer consits of a cast fitting which is secured to the center of the top head and extends arms, or spokes, in the direction of each adjacent element. The spacer arms are machined to precise lengths, and butt against the arms from adjacent spacers, holding the element rigidly in place.

The moderator elements and the reflector elements themselves are identical. However, in the reflector region, the scalloped corners are filled with circular canned graphite logs to increase the graphite density. These filler elements screw into the bottom grid plate; the top head of the element contains a screwdriver-type slot to be used for removal. 


\section{Control Rods}

The control rod system consists of 13 shim-regulating rods and 15 safety rods which regulate the reactor power level and provide for emergency setback or shutdown when required. The rods can be operated automatically by the plant control and protective systems or manually by the operator at the control console.

Each rod consists of a 12-1/2-ft column of boron-nickel rings assembled on a stainless steel pull-tube (Figures 15 and 16). The rods move within Zircaloy II thimbles which are installed in process channels in the reactor core. Each thimble is supported and sealed at the loading face shield and extends down $38 \mathrm{ft}$ to the bottom of the core. Check valves in the helium lines within the thimbles prevent the helium from escaping should the drive mechanisms be removed. Shielding is provided in the thimbles and in the rods in the region of the reactor loading face shield.

a. Shim Regulating Rods

The shim-regulating rod drive mechanism (Figure 15) consists of a ballnut screw assembly, with the rod connected to the nut and the screw driven through a clutch by a motor and a gear reduction unit. The drive mechanism is losated in a 14-ft column above the loading face shield; an induction motor and gear train assembly is mounted at the top of the column.

These actuator columns can be disconnected from the rod assemblies at the reactor loading face shield. The columns must be removed during any core component handling operation to make the loading face shield accessible to the fuel handling machine. A single carriage is used to support and transport the 28 columns (shim-regulating and safety).

The rod speed is $13.5 \mathrm{in.} / \mathrm{min}$ and the rod travel is $13 \mathrm{ft}$. In the full-down position, the neutron absorbing column is centered in the active core. In the full-up position, the bottom of the column is at the upper interface between the active core and the reflector. The time required to withdraw or insert the rods is $11.5 \mathrm{~min}$. An interlock prevents the shim regulating rods from being raised until all the safety rods are fully withdrawn. The control rods are equipped with limit switches which stop the drive motors at upper and lower 


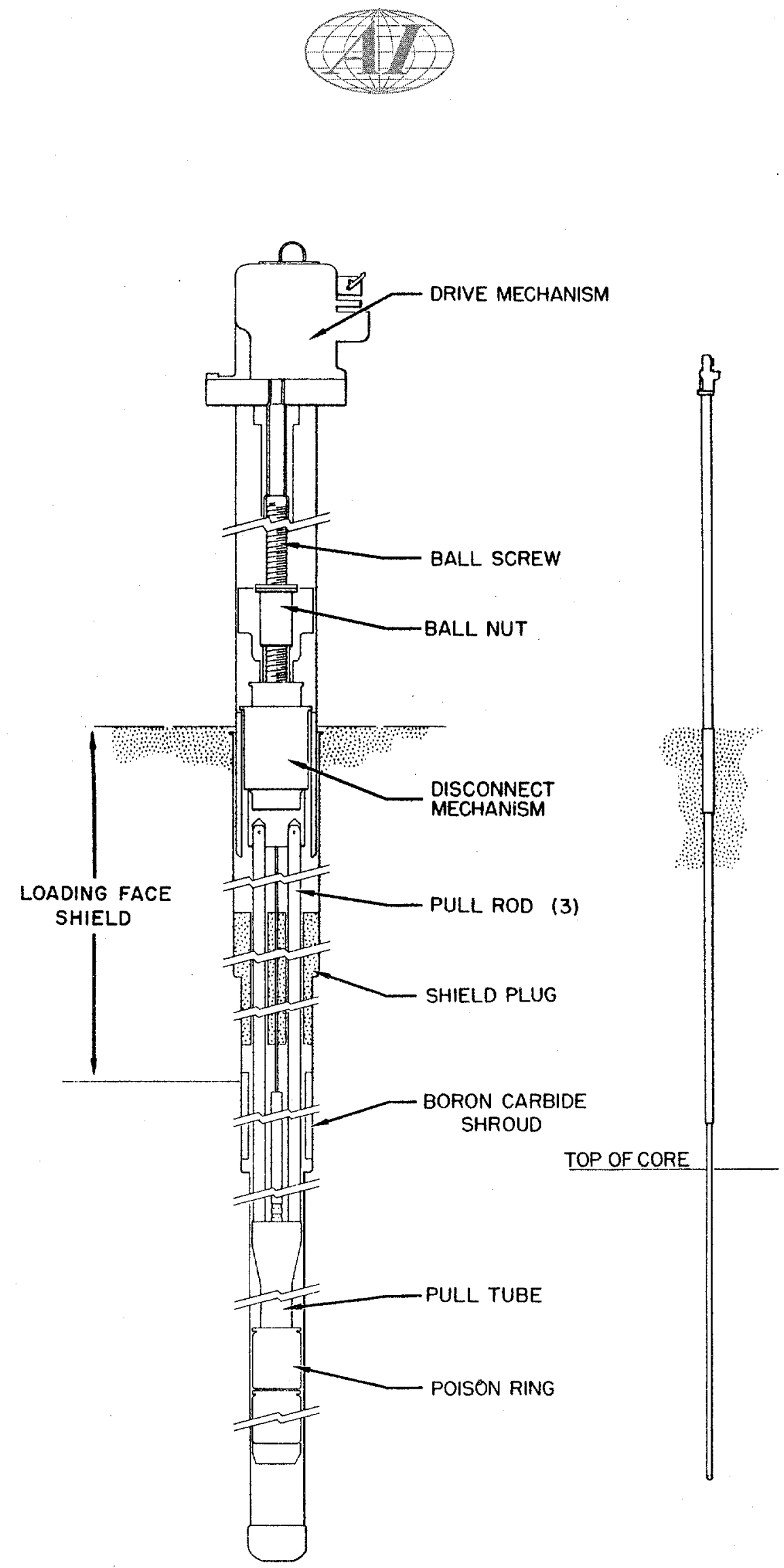

Fig. 15. Shim-Regulating Rod

IV -12

$$
46 \mathrm{~A}
$$



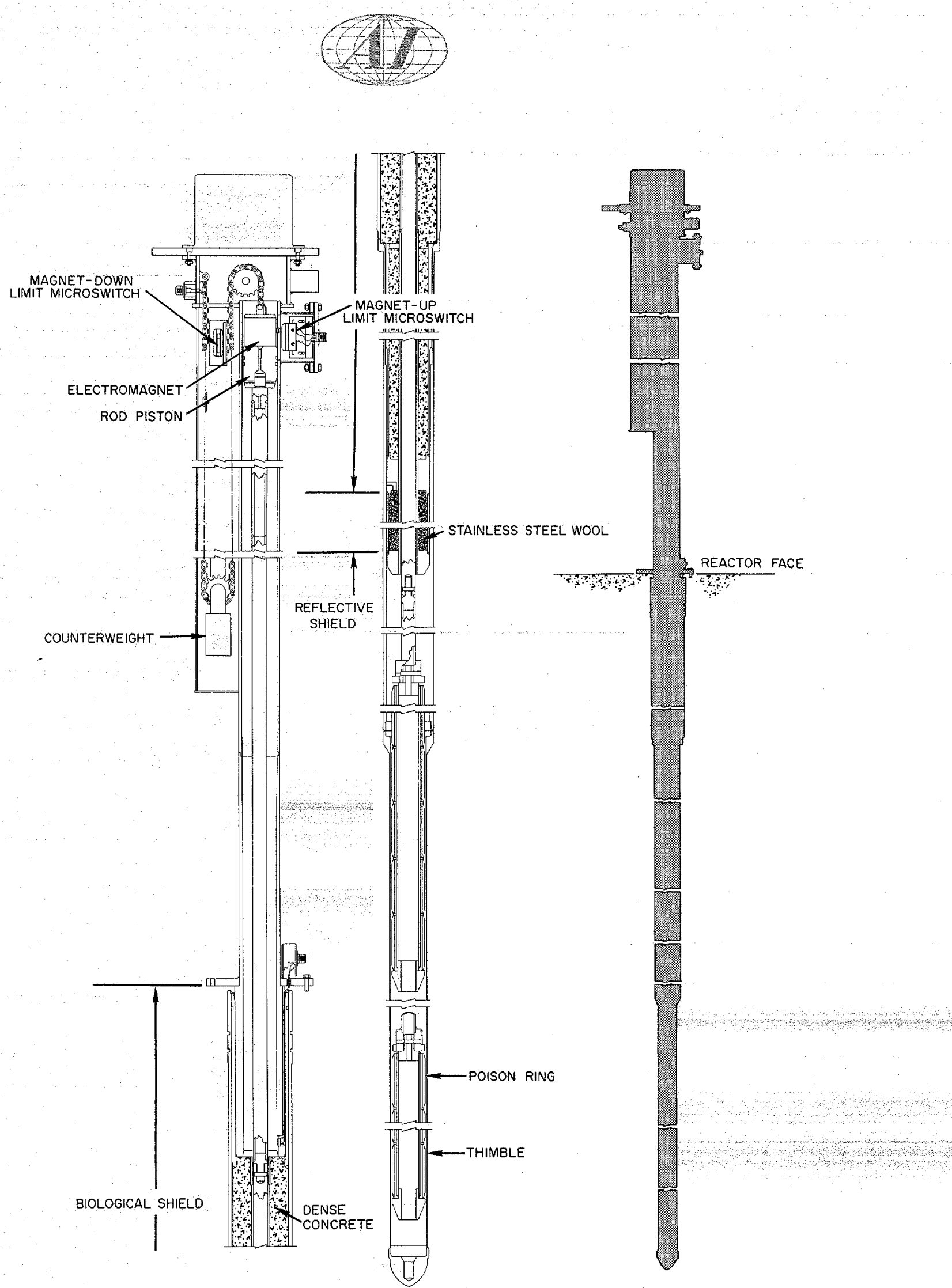

Figure 16. Safety Rod 


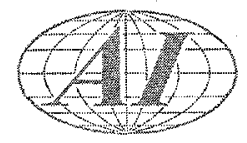

limit positions. Upper and lower physical stops are also provided. The drive mechanisms are torque-limited in case binding occurs or a limit switch fails. Rod position indicators continuously show the position of each control rod.

The reactivity contained in the shim-regulating rods and the maximum reactivity insertion rate of the rods are discussed in section $\mathrm{XI}$.

\section{b. Safety Rods}

The safety rods are similar in design to the shim-regulating rods, but their drive mechanisms differ considerably. Each safety rod is driven by a chain and sprocket coupled to a motor and gear reduction unit (Figure 16). The entire drive mechanism is located above the loading face shield and is supported and can be moved by the support carriage described previously.

The rod drive speed, both in and out, is $13.5 \mathrm{in.} / \mathrm{min}$. This gives a maximum reactivity rate of $0.027 \% / \mathrm{sec}$ which is measured with all rods moving in a region of maximum reactivity differential worth (section $\mathrm{XI}$ ).

To prevent thermal damage to the safety rod rings, an interlock prevents the rods from being motor driven into the core when the reactor is above $3 \%$ of full power; however, the rods can be dropped at any time. Once the shim regulating rods have been raised off their lower limits, the safety rod motors cannot be driven downward until after a scram occurs. The time required to withdraw the entire bank of safety rods is $11.5 \mathrm{~min}$; the same length of time is required to lower the drive mechanisms after scram. The total rod travel is $13 \mathrm{ft}$. The drive mechanisms are equipped with upper and lower limit switches and physical stops.

The safety rods are held to their drive mechanisms by electromagnets. When a scram occurs, the magnets are de-energized, allowing the rods to drop into the core. Impact snubbers decelerate the falling rods and prevent damage to the rods or to the thimbles. The maximum safety rod response time, measured from the instant a scram signal is initiated until the rods start to fall, is $300 \mathrm{msec}$. The free-fall distance before snubbing begins is $7 \mathrm{ft}$. Indicators in the control room show the safety rod drive mechanism positions, show whether the rods have fallen to their correct bottom positions after a scram, and show whether the rods are in contact with their magnets and are capable of being relatched.

IV -14

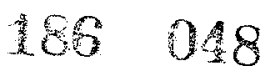




\section{(11)}

\section{Reactor Structure}

The reactor core assembly is contained in a stainless steel reactor vessel which is $19 \mathrm{ft}$ in diameter and $33 \mathrm{ft}$ high (Figure 12). The reactor vessel is of welded construction having walls which are $3 / 4$ in. thick, except for the base and lower sides and a section near the top of the core, which are 2 in. thick. In the lower 2-in. -thick section, which extends up about 5-1/2 ft from the base, the sodium inlet pipes enter the reactor vessel. In the 2 -in. -thick section near the top of the core assembly, which extends for about 4-1/2 ft, the sodium outlet pipes are connected to the reactor vessel. Three main sodium inlet nozzles are located, two on one side of the vessel and one on the other, at about 28 in. above the vessel base. They connect to the 14-in. OD cold-leg piping of the primary sodium loops. The moderator coolant inlet nozzle enters the reactor vessel about $4-1 / 2 \mathrm{ft}$ above the vessel base. It connects the 6 -in. OD inlet pipe to the plenum between the grid plate and the bottom of the moderator elements. Sodium outlet nozzles leave the reactor vessel, two on one side and one on the other (in reverse order to main inlet nozzles), at about $23 \mathrm{ft}$ above the vessel base. They lead into the 16-in. OD pipes which carry the hot sodium to the primary sodium pumps. All of the sodium nozzles are welded to the reactor vessel. At the top, a stainless steel bellows assembly seals the reactor vessel to the upper cavity liner to prevent sodium vapors and the helium atmosphere from escaping; and at the same time allows for thermal expansion and contraction of the reactor vessel, At installation, the bellows is cold-sprung so as to lower the operating stresses; and is designed for a 5-psi internal pressure at operating temperatures.

The reactor vessel contains the core, a bottom grid plate, and upper, lower, and inlet-plenum thermal shock liners. The grid plate, on which the moderator elements are supported and positioned, is a stainless steel disc, approximately $18 \mathrm{ft}$ in diameter and 1 in. thick. It is supported by a ring which is welded around the inside of the reactor vessel, and also by pedestals located under each moderator can. It is located 42 in. above the bottom of the reactor vessel. The 205 holes in the grid plate connect the core process channels with the sodium inlet plenum below the grid plate. Upper and lower thermal shock liners are cylindrical shells supported by the core-clamp support ring which is welded around the inside of the reactor vessel approximately $22 \mathrm{ft}$ above the base of the vessel. The upper shock liner is $18-1 / 2 \mathrm{ft}$ in diameter and $13-3 / 4 \mathrm{ft}$ high. 


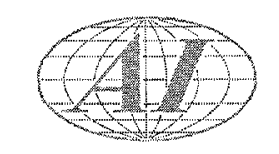

The lower shock liner is $18 \mathrm{ft}$ in diameter and 17-3/4 ft high. The inlet plenum shock liner is a cylindrical tank which lines the sodium plenum between the grid plate and the bottom of the reactor vessel. Openings are provided in the liner for the three sodium inlet nozzles, for the 205 core-process channels, and for the moderator-element support pedestals. Each of the thermal shock liners is fabricated from type 304 stainless steel, 1/4-in. thick. The gap between the shock liners and the reactor vessel contains stagnant sodium which acts as a thermal barrier to minimize thermal stresses in the reactor vessel.

The reactor vessel is surrounded by the thermal shield, whose function is to attenuate gamma and neutron radiation and thus prevent the concrete biological shield from overheating. The thermal shield consists of two concentric, carbon steel cylinders, each 2-3/4 in. thick, separated by a 1/4-in. gap. The inner cylinder is 19-1/2 ft in ID; the outer cylinder is $20 \mathrm{ft}$ in ID. Each cylinder is formed by a series of 10 adjacent, vertical, curved plates which rest on the bottom of the reactor outer vessel and are approximately $33-1 / 3 \mathrm{ft}$ high, extending to the top of the reactor vessel. The plates are held in position by clamps which are welded to the inside of the outer vessel.

The reactor outer vessel is a carbon steel tank approximately $20-2 / 3 \mathrm{ft}$ in diameter and $36 \mathrm{ft}$ high. The base is $2 \mathrm{in}$. thick; the wall thickness is $1 / 2 \mathrm{in}$. except for the lower $1 \mathrm{ft}$, where it is $2 \mathrm{in}$. thick. The wall is covered on the outside with a 12-in. layer of a fibrous, thermal insulating material.

Outside of the thermal insulation, pipe chases are provided for the sodium piping. Surrounding this space are the cavity liner and the concrete biological shield. The cavity liner (Figure 17) is a welded, steel-plate structure which covers the inner surface of the biological shield. The liner serves as the inner form for the pouring of the concrete. It is fabricated from $1 / 2$-in. -thick carbon steel plate, except for 1-in.-thick sections which make up the bottom surface, the top closure plate, the pipe chase backs, and the upper $5 \mathrm{ft}$ of the cylindrical section surrounding the reactor.

Cooling coils attached to the outside surface of the cavity liner remove heat that is transferred through the reactor insulation and heat that is generated in the concrete and in the liner by gamma radiation. The coolant is demineralized water, and the system is designed to maintain the temperature in the concrete at $150^{\circ} \mathrm{F}$ or less, and the surface temperature of the liner at $120-150^{\circ} \mathrm{F}$, under normal operating conditions.

IV- 16

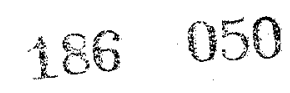




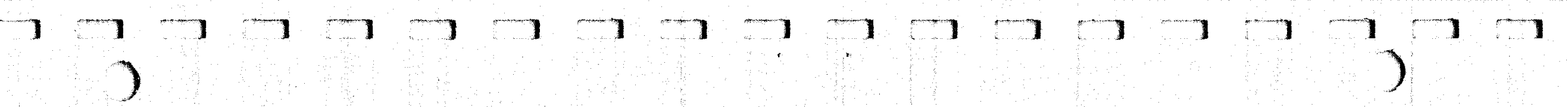

3
6
6

OADING FACE EL. $1440^{\prime} 6^{\prime \prime}$

EL.1420'0'

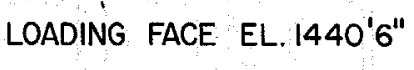

$\mathrm{EL} .1432^{\prime} 6^{\prime \prime}$

1

Figure 17. Reactor Cavity Liner $\left(19-10^{\prime \prime}\right.$ ID) PIPE TUNNEL DIAPHRAGM SEAI (II'-O"ID) EL $1394^{\prime} 7^{\prime \prime}$<smiles>[CH]1[CH]C1</smiles> 


\section{(4ii)}

The cavity liner is a gas-tight enclosure which envelops the reactor and the adjoining sodium piping and forms the secondary gas-confinement barrier. Helium lines, vent lines, and the conduit surrounding thermocouple leads, heater leads, etc., are seal-welded to the liner. At the main sodium pipe outlets, diaphragm seals separate the helium atmosphere in the cavity from the nitrogen atmosphere in the outer pipe tunnels. The normal operating pressure within the cavity liner is $0.25 \mathrm{psig}$. The design pressure for this structure is $10 \mathrm{psig}$.

A concrete biological shield completely encloses the reactor cavity liner. The concrete at the bottom of the reactor cavity is the foundation which supports the reactor. The side walls serve as shielding and also support the loading face shield.

The loading face shield directly above the reactor core is a cylindrical plug, 6-1/3 ft thick and approximately $20 \mathrm{ft}$ in diameter at the top surface, stepped down to $18-1 / 2 \mathrm{ft}$ at the bottom to minimize radiation streaming. The shield plug is dense concrete encased in a type-405 stainless steel form. The steel plates which make up the bottom and side surfaces are seal welded together. The bottom surface consists of a 1 -in. -thick sheet of type-405 stainless steel. Above this is a 1-1/2 in. thick layer of lead in which cooling coils are embedded. The lead serves as a heat transfer medium to help transfer to the cooling coils both sensible heat from the sodium pool and heat generated in the concrete. A reflective thermal insulator is suspended from the bottom surface of the shield plug. The insulator consists of a séries of 13 horizontal stainless steel plates, 1/32 in. thick. The loading face shield weighs 400 tons and is supported by a ring-type ball thrust bearing which encircles it just below the top surface. The design also incorporates a frozen metal alloy (cerrobend) seal which prevents the escape of gases from the reactor.

The loading face shield has 207 openings into the reactor core, 205 of which are directly above the core process channels. The remaining two accommodate sodium liquid level instrument elements. The stainless-steel sleeves which form the openings are 6-1/2 in. in diameter at the top surface, stepped down to about 5 in. at the bottom. The shield plugs are approximately $1 / 4$ in. smaller in diameter. Each fuel element is suspended from the shield plug above it. In those openings occupied by shim and safety rods, the drive mechanisms extend through the top shield into the reactor room. Each shield plug has an O-ring gas seal and a retaining ring to lock it to the top shield. 


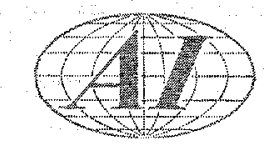

In addition to the core position holes, the loading face shield has three large circular openings, 58-1/4 in. in diameter at the top, stepped down to 56-1/2 in. at the bottom, through which moderator and reflector elements can be removed or maintenance operations performed. By correctly positioning the shield, any moderator or reflector element is accessible through one of these large openings. However, this operation is not a normal one and it would require an extensive reactor shutdown.

\section{B. SODIUM HEAT TRANSFER SYSTEM}

The sodium heat transfer system consists of three independent circuits each directly connected to the reactor vessel. Each circuit consists of a radioactive primary loop which transfers thermal energy from the core to an intermediate heat exchanger, and a nonradioactive secondary loop which carries the heat from the heat exchanger to a steam generator. The reason for the primary-secondary loop arrangement is to separate the steam system from the radioactive primary sodium.

A flow diagram of one heat transfer circuit is shown in Figure 18. The primary loop includes a variable speed centrifugal pump, and intermediate heat exchanger, power-actuated valves in the reactor inlet and outlet lines, and a check valve in the inlet line. The throttling valve in the inlet line serves as a flow control valve. It is used mainly during reactor shutdown to control the convective sodium flow which removes afterglow heat from the reactor core. The check valve prevents sodium backflow.

Secondary loop components are the heat exchanger, an expansion tank, a variable speed centrifugal pump, a power-actuated throttling valve, and the steam generator. The expansion tank has a capacity of about $300 \mathrm{ft}^{3}$. It provides space to accommodate sodium volume changes and provides a free surface for eliminating entrained gas. It also serves as a pressurizing tank. By means of the helium atmosphere in the tank, the secondary loop pressure is maintained at a higher level than the primary loop pressure to insure that any leakage between the two loops in the intermediate heat exchanger would be from the nonradioactive secondary loop into the radioactive primary loop. The throttling valve, which is in the inlet line to the intermediate heat exchanger, is very similar to the valve in the reactor inlet line. It functions as a flow control valve for convective flow when the reactor is shut down, to help maintain the thermal gradient across the heat exchanger. 


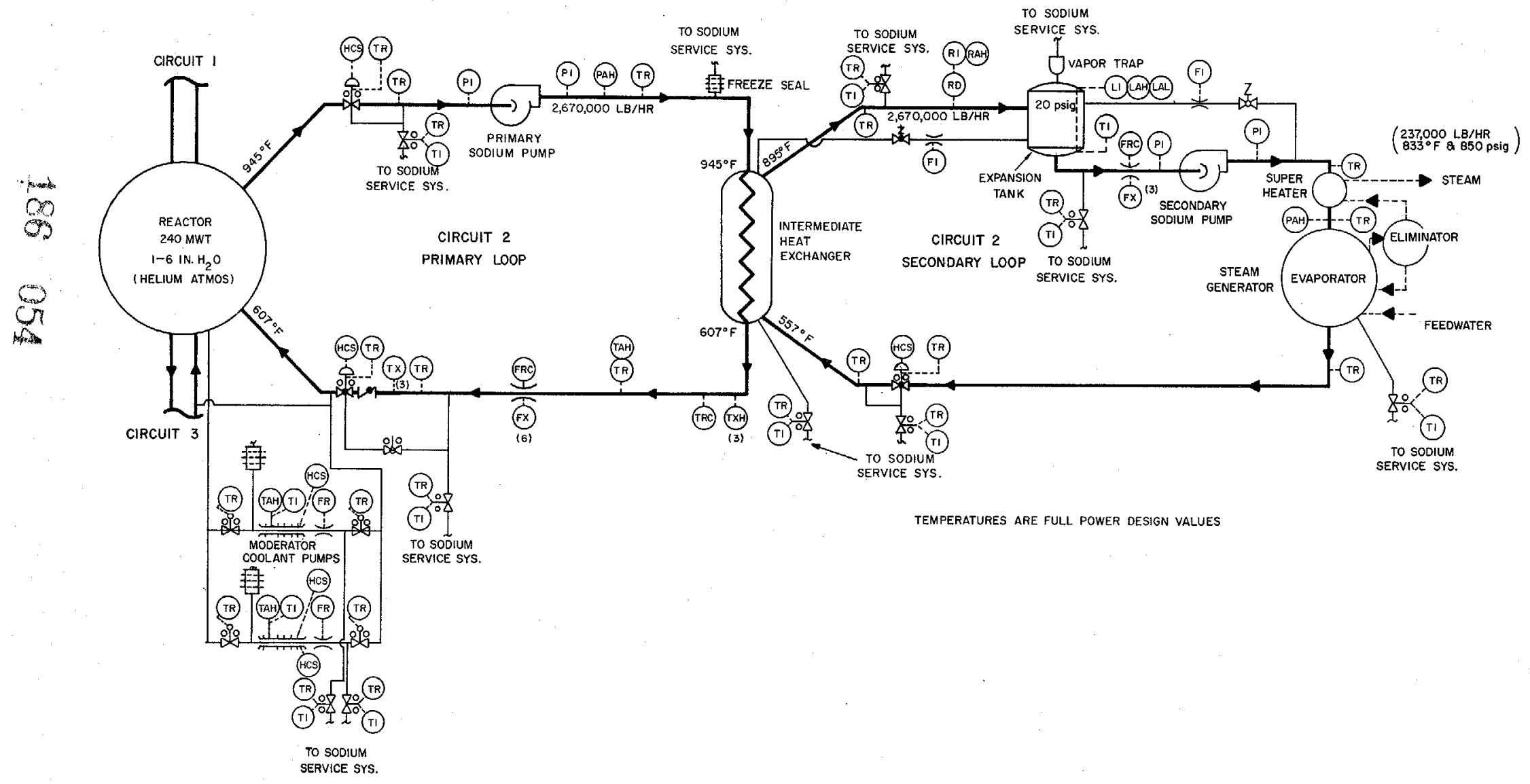

Figure 18. Sodium Heat Transfer Circuit 


\section{(4i1)}

During normal, full-power operation, primary sodium enters the reactor vessel at $607^{\circ} \mathrm{F}$. As it passes through the core to the sodium pool above, it is heated to $945^{\circ} \mathrm{F}$. At this temperature the sodium pool extends approximately $11 \mathrm{ft}$ above the top of the moderator cans. Sodium is drawn from the pool by the primary pumps and discharged through the intermediate heat exchangers. Here the energy picked up in the core is transferred to the secondary loops and the primary sodium returns to the core at $607^{\circ} \mathrm{F}$. The nominal sodium flow in each primary and secondary loop, with the reactor at full power, is $2,670,000 \mathrm{lb} / \mathrm{hr}$, giving a total flow in the three primary loops of $8,000,000 \mathrm{lb} / \mathrm{hr}$. During normal operation, the sodium flow rate in each loop depends on the pump speed, which is adjusted by the plant control system to maintain the reactor inlet sodium (cold leg) temperature at its set point.

The reactor vessel serves as an expansion tank for the primary loops. The reactor vessel pressure, maintained by means of the helium atmosphere above the core sodium pool, is kept slightly positive, 1 to 6 in. $\mathrm{H}_{2} \mathrm{O}$, to prevent inleakage of air and insure an inert gas atmosphere.

The secondary sodium is pumped from the expansion tank, through the steam generator, through the intermediate heat exchanger, and back to the expansion tank. At full power, the sodium is heated from 557 to $895^{\circ} \mathrm{F}$ in the intermediate heat exchanger, and cooled back down to $557^{\circ} \mathrm{F}$ in the steam generator. The sodium flow rate depends on the pump speed which is adjusted to maintain constant steam pressure. At nominal full power, $237,0001 \mathrm{~b} / \mathrm{hr}$ of steam at $833^{\circ} \mathrm{F}$ and 850 psig are produced in each steam generator. The corresponding total steam flow at the turbine throttle is $710,0001 \mathrm{~b} / \mathrm{hr}$ at $825^{\circ} \mathrm{F}$ and $800 \mathrm{psig}$.

All piping and components of the primary loops are located in shielded cells below the reactor room floor level. A nitrogen atmosphere is maintained in these cells. The pressure is kept slightly above atmospheric to prevent any inleakage of air. The reactor cavity and the pipe tunnels are separated by a diaphragm seal assembly. Immediately outside the diaphragm seal are the inlet-and outlet-line blocking valves. The piping then proceeds through the shielded pipe tunnels to three individually shielded cells, each of which contains the pump and intermediate heat exchanger of one of the primary loops. Separating the major components of the three primary loops, and shielding them from one another, permit access to the intermediate heat exchanger cell of a shutdown loop for servicing under certain 


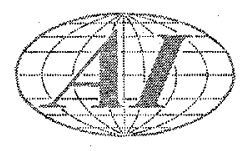

conditions. If access to the cell is for inspection or servicing while the sodium piping and intermediate heat exchanger remain intact, the particular loop can be drained and the cell can be entered while the reactor and the two remaining loops are in operation. If the servicing involves cutting into the primary sodium loop, the reactor must be shut down and the sodium level in the reactor vessel must be drained to a level below the elevation of the blocking valves.

The outlet (hot-leg) piping between the core and the primary pumps is 16 -in. $O D, 0.25$ in. wall thickness. The rest of the piping in the primary loops is 14-in. $O D, 0.25-i n$. wall thickness. The pumps, expansion tanks, and steam generators of the secondary loops are located above grade and are not shielded. The piping in the secondary loops is 14-in. OD, 0.25-in. wall thickness.

All piping and equipment in the sodium heat transfer system which come in direct contact with sodium are stainless steel except the steam generators which are chrome-moly steel. Because the melting point of sodium is $208^{\circ} \mathrm{F}$, the system is equipped with electrical preheating capable of producing and maintaining a temperature of $350^{\circ} \mathrm{F}$. Helium and vent connections are provided throughout the system to purge air from all piping and equipment prior to admitting sodium.

\section{Main Sodium Pump}

The main sodium pumps (Figure 19), both primary and secondary, are of the overhung, centrifugal type. They are vertically mounted and employ frozen sodium seals at the shaft and at the case.

The primary pumps are mounted in the shielded heat exchanger cells. The pump shafts extend upward through the concrete to the reactor room above the cell. The pump motors are mounted in the reactor room at floor level. The pumps are designed so that the internal parts, including impeller, shaft, pump cover, gland, and bearings, can be removed through the top without disturbing the pump case or piping. This allows maintenance work to be done on the pumps without cutting into the sodium system. The primary pumps are provided with biological shielding within the pump case.

The secondary pumps are located in the steam generator room. They are almost identical to the primary pumps except that they do not require shielding or the extended pump shaft. As with the primary pumps, the internal parts of the secondary pumps can be removed without disturbing the pump case or piping. 


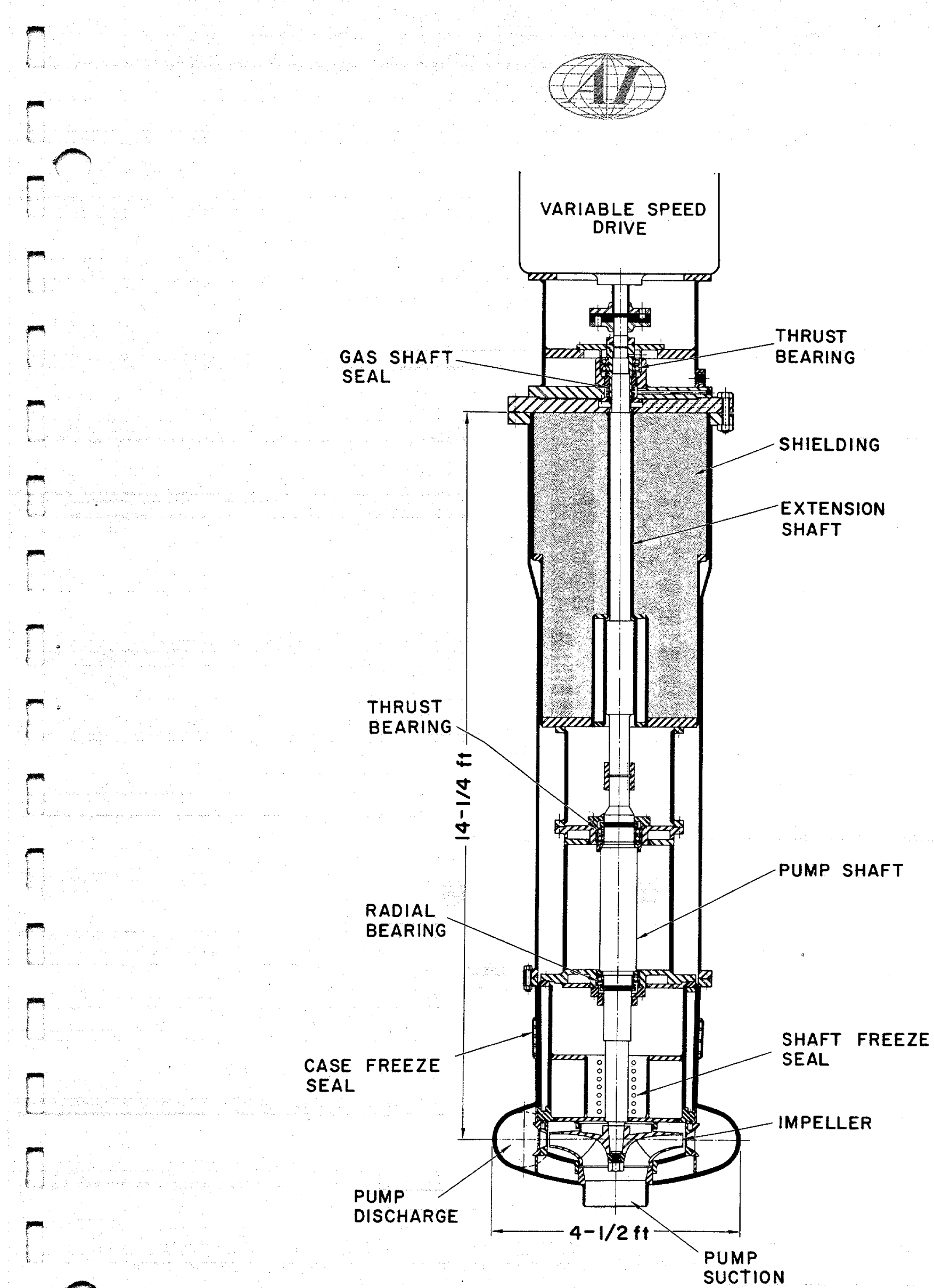




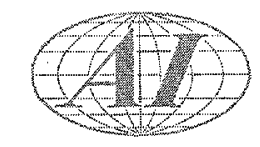

All main sodium pumps are equipped with frozen sodium seals. The pump case seal and the shaft stuffing box seal are made by freezing and holding the sodium leakage at these points. The case seal is made at an elongated case joint surrounded by a jacket through which tetralin coolant (exit temperature of $115^{\circ} \mathrm{F}$, sodium melting point of $208^{\circ} \mathrm{F}$ ) is circulated. The flow of coolant is controlled to produce a solid ring of frozen sodium in the case joint, eliminating the need for a conventional gasket. A frozen sodium rotating seal is made at the shaft stuffing box by circulating tetralin coolant in a jacketed gland installed in the stuffing box. The coolant flow is adjusted to remove conducted heat and the frictional heat generated by the shaft. To remove the internal assembly from the installation, the case freeze seal must be melted by throttling the flow of tetralin in the cooling jackets. Auxiliary heaters are installed in the pumps to provide heat if required. Above the freeze seals, an inert helium atmosphere is maintained in the pump case at a pressure of about 2 psig to prevent contamination of the sodium. The gas seal at the top of the pump is a double mechanical type, oil filled, and includes an oil reservoir, an oil slinger, and a drain assembly designed to prevent leakage of oil into the pump housing.

Each pump is driven by an a-c, induction-type motor through a variable speed, electromagnetic coupling. Each pump can operate through a continuous speed range of from zero to $102 \%$ of rated rpm. Pump design information is summarized in Table VII.

TABLE VII

PRIMARY AND SECONDARY PUMP DESIGN DATA *

\begin{tabular}{l|l|c}
\hline \multicolumn{1}{c|}{ Characteristic } & Primary & Secondary \\
\hline Capacity & $6460 \mathrm{gpm}$ & $6080 \mathrm{gpm}$ \\
Total dynamic head & $150 \mathrm{ft} \mathrm{Na}$ & $150 \mathrm{ft} \mathrm{Na}$ \\
NPSH & $25 \mathrm{ft} \mathrm{Na}$ & $25 \mathrm{ft} \mathrm{Na}$ \\
Case design pressure & $100 \mathrm{psig}$ & $100 \mathrm{psig}$ \\
Case design temperature & $1000^{\circ} \mathrm{F}$ & $1000^{\circ} \mathrm{F}$ \\
Sodium properties & & \\
Temperature & $945^{\circ} \mathrm{F}$ & $895^{\circ} \mathrm{F}$ \\
Specific gravity & 0.83 & 0.84 \\
Viscosity & 0.24 centipoise & 0.25 centipoise \\
\hline
\end{tabular}

* At nominal power rating.

IV -24 


\section{Main Sodium Valves}

The primary sodium blocking valves are split-wedge gate valves; the primary and secondary throttle valves are venturi ball-type valves. Each valve has a frozen sodium stem seal similar to the main pump seals. Sodium is frozen and held at the seal point by tetralin coolant which circulates around the seal and exits at about $125^{\circ} \mathrm{F}$. The valves are of conventional design except that the stems are 22 in. longer than standard to accommodate the freeze seal assembly.

The valves can be operated either automatically or manually. The valve operator for automatic service is a rotating air motor driving through a selflocking gear box. If an air failure should occur, the valve maintains its position. However, air failure is unlikely because the normal air supply has a backup emergency system. For manual opening and closing, each valve is equipped with a handwheel. The handwheel is disengaged during automatic operation so that it offers no resistance to valve movement.

\section{Intermediate Heat Exchangers}

The intermediate, sodium-to-sodium heat exchangers between the primary and secondary loops are of the shell-and-tube, counterflow design. The primary, radioactive sodium flows through the tubes; and the secondary, nonradioactive sodium flows through the shell. The exchangers are placed vertically in the cells to reduce sodium stratification problems at low flow rates.

The intermediate heat exchangers are of welded construction and are fabricated entirely from type-304 stainless steel. They are designed for a pressure of $100 \mathrm{psig}$ at $1000^{\circ} \mathrm{F}$. The design pressure drop on the tube side (primary sodium) is 5 psi; on the shell side (secondary sodium), 7 psi.

\section{Steam Generators}

Three steam generators are provided, one for each of the secondary sodium loops. Each steam generator consists of an evaporator, moisture eliminator, and superheater. Construction is of the shell-and-tube type, utilizing duplex tubes to prevent interleakage between sodium and water or steam.

The evaporator is a kettle-type design, with the water level carried in the

shell. No steam drum is provided, although an external moisture eliminator is used to assure dry steam output to the superheater. The tubes are the bayonet type, 


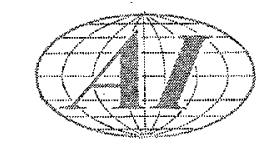

with the inner tube rolled against the outer tube to provide a good heat transfer bond. The outer surface of the inner tube is knurled to provide a third-fluid monitoring feature. The core tubes that direct the flow of sodium in the bayonet are also double walled, with a sealed-gas annulus to reduce heat leakage in a radial direction. The materials of construction are 2-1/2 $\mathrm{Cr}-1$ Mo for sodium service, and carbon steel where usable for water service.

The superheater is of similar construction, using orifice baffles on the shell side. Materials of construction are $5 \mathrm{Cr}-1 / 2 \mathrm{Mo}$ for sodium service and 2-1/4 Cr-1 Mo for steam service. Control of steam superheat (attemperation) is provided by bypassing a small amount of saturated steam from the evaporator through a control valve into the superheated steam outlet.

A third fluid system, helium, is provided to monitor the duplex tubes for leaks. The helium system pressure is set at approximately $300 \mathrm{psig}$. In the event of a sodium leak, the third fluid pressure falls to sodium pressure, which is less than 100 psig. In the event of a steam leak, the third fluid pressure rises to steam pressure, which is about 850 psig. The suspected pressure of a leak, as evidenced by the change of pressure in the third fluid system, does not require an immediate shutdown, since a single leak does not compromise the boiler. In an emergency the boiler could be operated indefinitely. It is recommended, however, that in the event of an indicated leak, the boiler be shut down over a period of from 4 to $8 \mathrm{hr}$.

\section{Steam Dumping System}

A steam-dumping system (Figure 20) capable of handling $110,000 \mathrm{lb} / \mathrm{hr}$ of steam at $800 \mathrm{psig}$ and $825^{\circ} \mathrm{F}$ is provided. The steam is condensed in a separate atmospheric boiler consisting of bent-tube heat-exchanger sections in a twocompartment open tank. Raw water for the boiler tank is provided from elevated storage. The steam dumping system is used as the reactor heat sink during startup and shutdown, and as a backup pressure-control means during normaloperation.

6. Emergency Feedwater System

In the event of outage of the main feedwater pumps, water is supplied to the steam generators by means of a small turbine-driven feed pump and a condensate pump. The pumps are sized to provide more than adequate cooling for reactor afterglow heat. The feedwater system is shown schematically in Figure 21. 


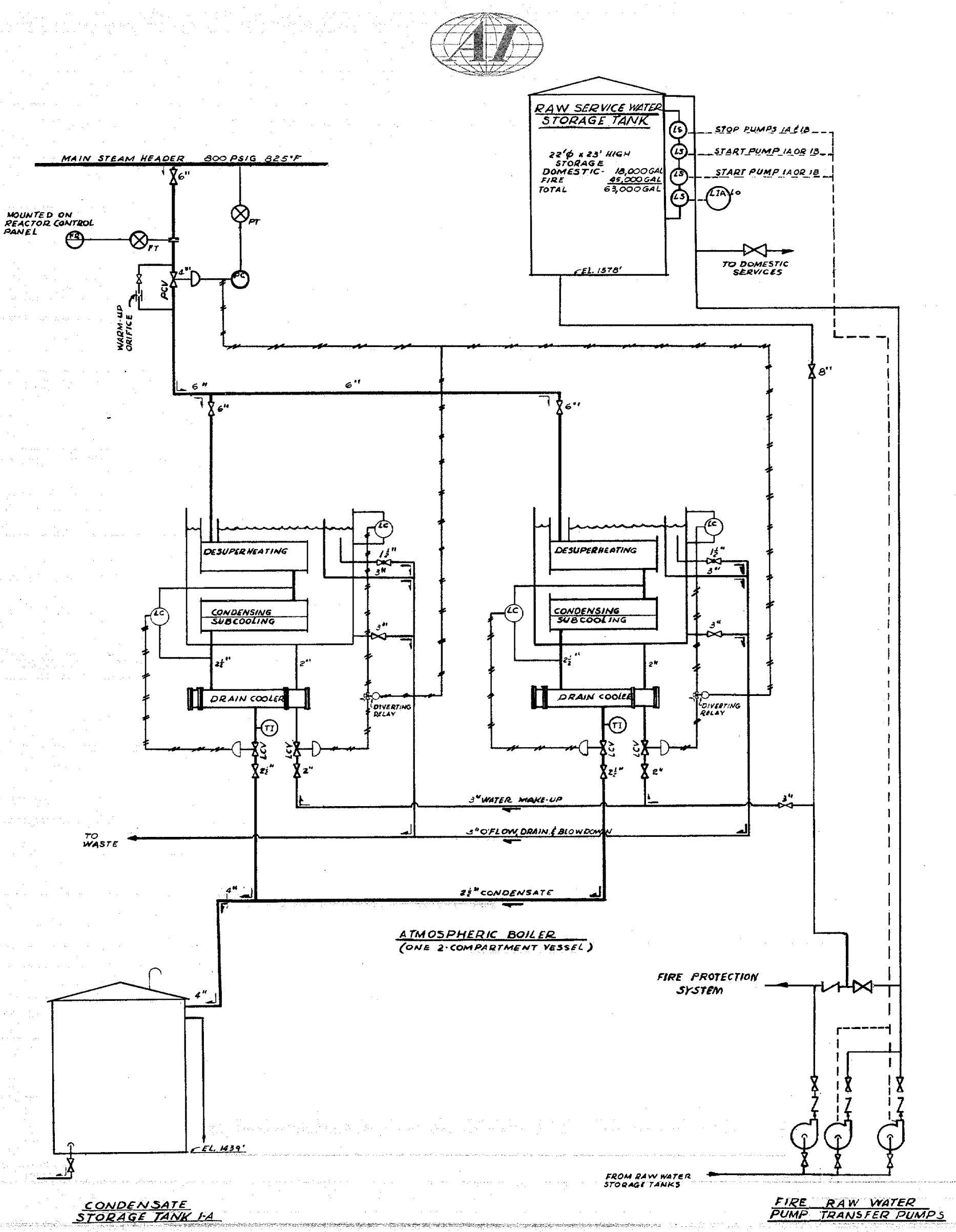

Figure 20. Steam Dumping System $186 \quad 061$ 


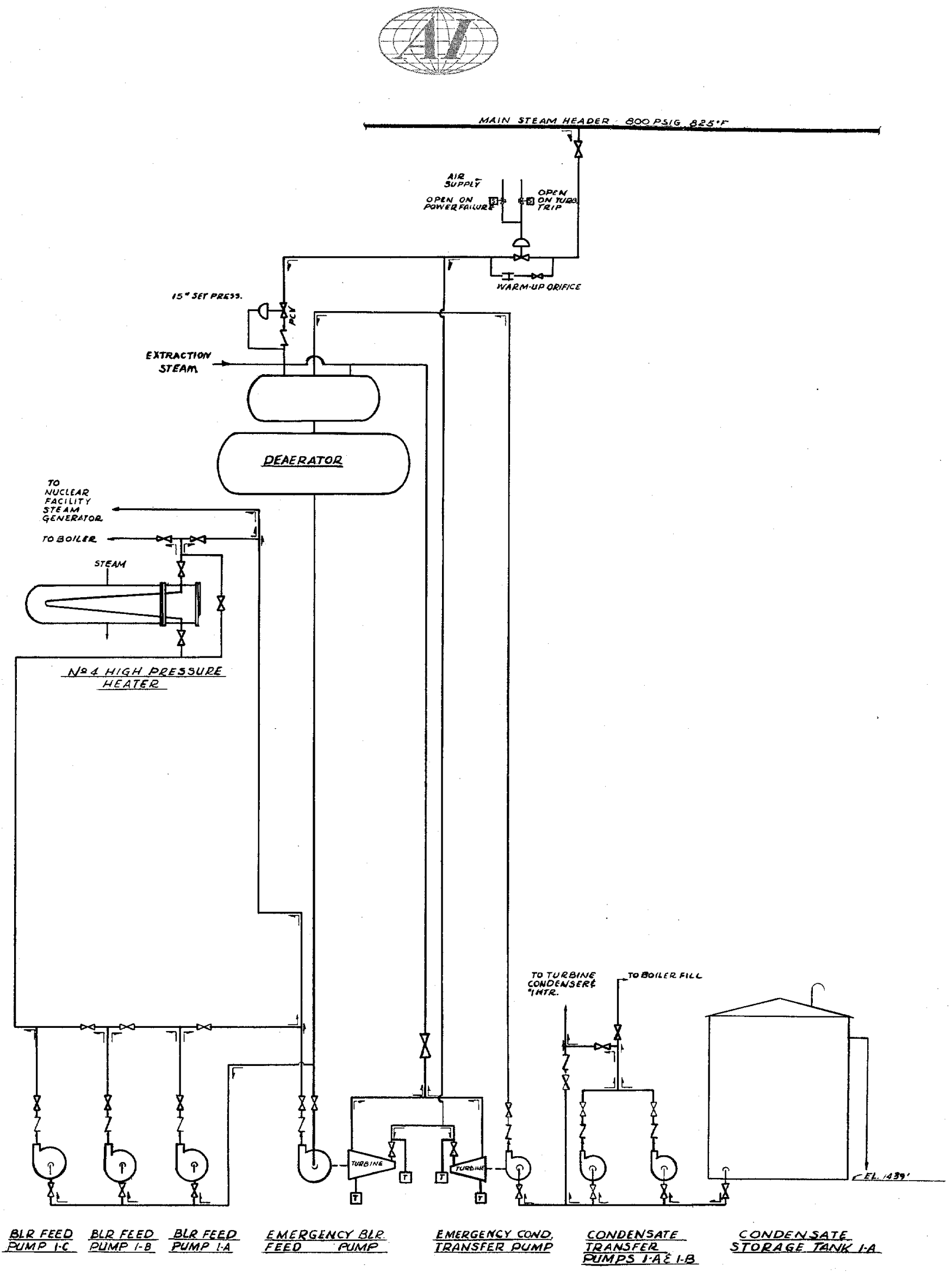

Figure 21. Feedwater System 


\section{INSTRUMENTATION AND CONTROL}

The reactor instrumentation can be divided into nuclear instrumentation, sodium instrumentation, plant control system, plant protective system, and radiation monitoring system. The nuclear instrumentation circuits measure and indicate (or record) neutron flux over the entire operating range of the reactor, starting from source level. The sodium instrumentation measures and indicates (or records) pressures, flows, temperatures, and liquid levels in the sodium systems. The plant control system operates the reactor plant (adjusts control rods, pump speeds, etc.) in accordance with plant load demand either by manual (semiautomatic) actuation or automatically. The protective system, consisting of alarm, setback, and scram circuits, safeguards the reactor against malfunctions and errors which might otherwise create hazardous conditions. The radiation monitoring system measures radiation levels throughout the plant.

\section{A. NUCLEAR INSTRUMENTATION}

A nuclear instrumentation block diagram is shown in Figure 22. The system is divided into nine channels: two count-rate, two log-N, and five power level. The system covers the range from source level to approximately $150 \%$ of rated power. The neutron detecting instruments are located in thimbles which extend from the reactor room floor downward to a position at the cavity liner near the bottom of the active reactor core. All of the thimbles are sealed and are cooled externally by the water cooling system for the cavity liner.

The two count rate channels are used for reactor startup. Each channel consists of a $\mathrm{BF}_{3}$ chamber transmitting through a preamplifier and amplifier to a $\log$ count rate meter and period meter. The log count rate in either one of the two channels is recorded and the period measurements are indicated. The two $\log -\mathrm{N}$ channels are also used for reactor startup. In these channels, compensated ionization chambers transmit to logarithmic amplifiers and then to period meters and to two neutron flux recorders. The period signals tie into the plant protective system and will initiate an alarm and a subsequent setback if the period becomes shorter than preset limits. 


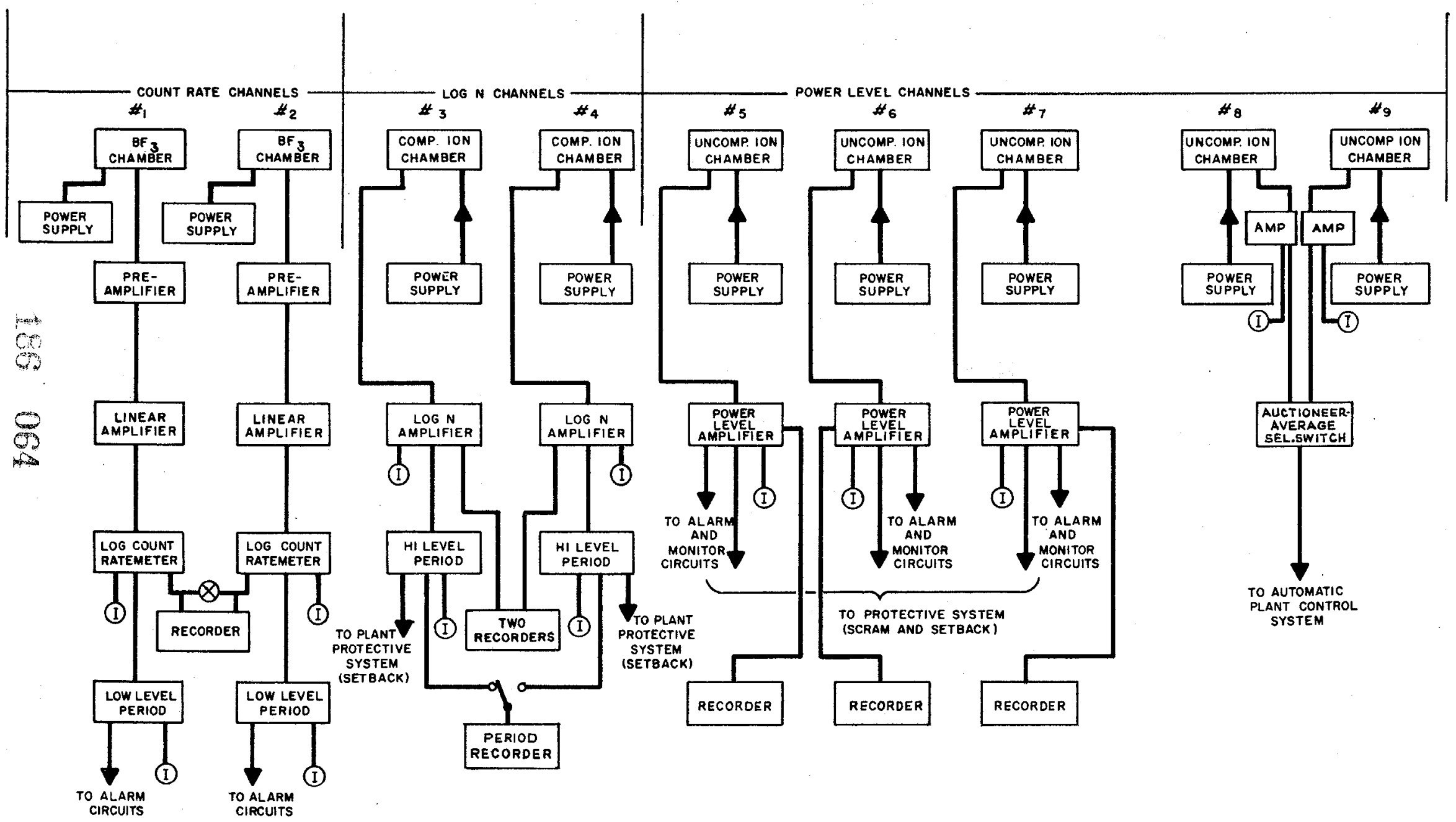

Figure 22. Nuclear Instrumentation 


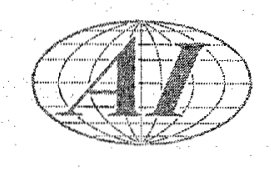

The linear power level channels use uncompensated ionization chambers over the range of normal reactor power operation. Three of these channels transmit signals to the plant protective system and are used in the power-flow ratio scram, setback, and alarm circuits. Signals from these circuits go through a coincident circuitry arrangement in the plant protective system. The coincident circuitry is such that at least two of the three channels must register an abnormal reading to initiate a setback or scram. If only one channel reads abnormally, an alarm is sounded. Signals from the remaining two power level control channels are directed through amplifiers and through an auctioneering averaging selector switch to the neutron flux controller which positions the shim regulating rods in response to plant load demands.

\section{B. SODIUM INSTRUMENTATION}

The sodium systems are provided with instrumentation to measure pressures, temperatures, flow rates, and liquid levels. The measurement points for one circuit are shown in Figure 18; the three circuits are identical in this respect.

Fuel channel sodium exit temperatures in the reactor core are measured by thermocouples installed at the top of each fuel element. These temperature signals are used for normal reactor control and also are transmitted through coincident circuitry to the plant protective system to initiate a setback or scram in the event of excessive fuel channel sodium outlet temperatures. All fuel channel exit thermocouples are sequentially monitored and the temperatures are recorded. Thermocouples are also located throughout the reactor vessel; they are monitored by means of a single pushbutton type selector and indicator. The sodium liquid level in the reactor vessel is measured over the range expected during normal plant operation; high and low liquid level alarms and scram circuitry are provided.

All instrument parts exposed to sodium are fabricated from corrosion resistant steel and are of all welded construction. In the radioactive sodium loops, pressure transmitters are employed; the pressure sensing elements are double-sealed systems utilizing bellows or diaphragm assemblies. In the nonradioactive loops, the pressure sensing instruments are of the force balance transmitter type, again using double-sealed systems utilizing either bellows or diaphragm sensing elements. Well-type thermocouples are used to measure sodium temperatures which are critical, and these thermocouples are removable 


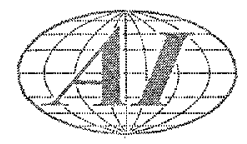

without opening the sodium systems. Temperatures which are not critical are measured from thermocouples located directly on the pipe. Temperature information required for preheating is obtained primarily from thermocouples on the sodium vessels and piping.

Sodium flow rates are measured by magnetic flowmeters. Alarm coils and continuous type transducers are used for measuring sodium liquid levels. Where continuous level measurement is necessary, an additional thimble is provided which is used for calibration purposes and for alarm coils when required.

Sodium leak detectors are located in the cells of the primary loops, and they are inaccessible during operation of the loop. Each detector consists of two electrodes which become shorted when they both contact sodium. In general, they are located at positions on (or near) piping, valves, pumps, and other components where leakage might occur or be readily detected.

\section{PLANT CONTROL SYSTEM}

The plant control system provides for automatic operation over the range of 20 to $100 \%$ of load, or for manual or semiautomatic operation at any load and during plant startup. The system is designed to provide operational flexibility comparable to that of a conventional plant.

The plant is designed as a load following system; that is, reactor power level and sodium flow rates are varied according to steam demand. A diagram of the plant control system is shown in Figure 23. During normal operation an increase in plant load which initiates opening the turbine inlet valves will result in an increased steam flow and decreased steam pressure. Signals representing steam flow and steam pressure are immediately transmitted to both the primary and the secondary sodium pumps, increasing the pump speeds proportionately. The increase in sodium flow through the reactor acts on the neutron flux controller to withdraw the shim-regulating rods, increasing the reactor power level. These actions represent the initial response of the control system to a change in plant load. Readjusting (reset) signals then come into play to prevent cumulative errors in these initial responses from driving the controlled variables out of limits. The secondary sodium flow rates are reset to maintain steam pressure at its set point. The primary sodium pump speeds are reset to maintain the 

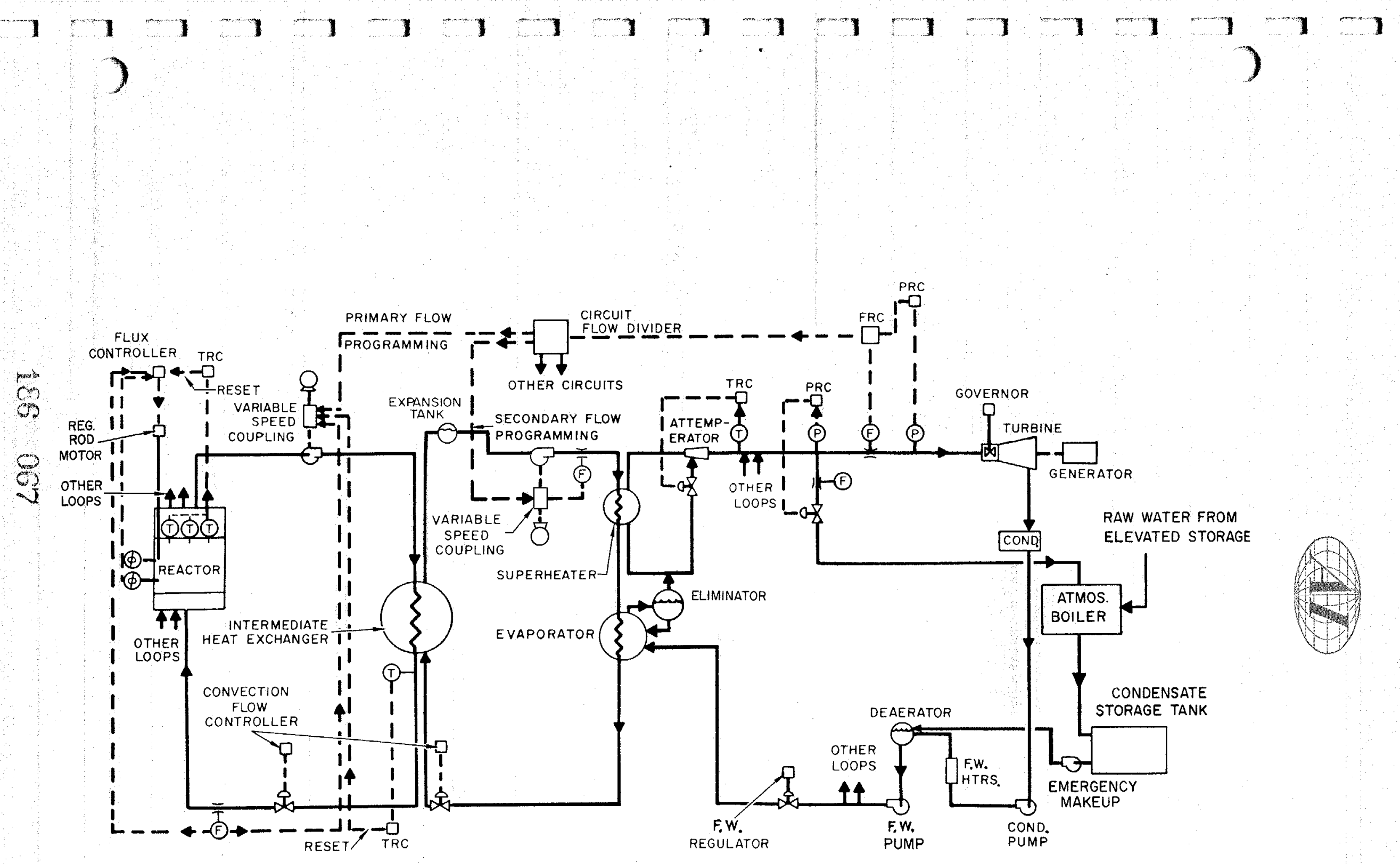

Figure 23. Plant Control System 


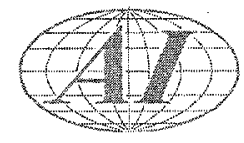

programmed, reactor inlet sodium temperature at its variable set point. The shim-regulating rods are reset to maintain fuel channel exit temperature at its set point.

A conventional, three element, feedwater control system (feedwater flow adjusted to match steam flow and reset to maintain a constant evaporator liquid level) provides the correct amount of water to the steam generator. The attemperator controller adjusts the flow of saturated steam from the evaporator to the attemperator so as to hold the steam temperature to the turbine constant. The characteristics of the superheater are such that the unattemperated steam temperature at the outlet of the superheater is above normal $\left(833^{\circ} \mathrm{F}\right)$ at all loads below full load.

The following list and Table VIII indicate the major elements to be controlled as the plant load is changed during normal operation.

Quantities Controlled:

1) Reactor outlet sodium temperature (held constant)

2) Reactor inlet sodium temperature (programmed to fall slightly at . reduced loads)

3) Steam pressure to turbine (held constant)

4) Steam temperature to turbine (held constant)

Quantities Not Directly Controlled, and Allowed to Vary:

1) Secondary sodium hot leg temperature (rises slightly at reduced loads)

2) Secondary sodium cold leg temperature (falls slightly at reduced loads)

3) Feedwater temperature (falls at reduced loads)

4) Steam temperature at superheater outlet (rises at reduced loads)

In the event of a sudden load decrease too fast for the pressure control sys tem to follow (e.g., throttle valve trip), the backup pressure controller on the steam dump system directs steam to an atmospheric boiler and then to a condensate storage tank. Steam dumping ceases when steam pressure returns to normal. A further backup is provided by the steam generator safety valves. 
TABLE VIII

REGULATING ELEMENTS AND CONTROLLED QUANTITIES

\begin{tabular}{c|l}
\hline \multicolumn{1}{c|}{ Regulating elements } & \multicolumn{1}{c}{ Controlled Quantities } \\
\hline Shim regulating rod position & $\begin{array}{l}\text { Reactor power; fuel-channel outlet } \\
\text { sodium temperature }\end{array}$ \\
Secondary sodium pump speed & $\begin{array}{l}\text { Secondary sodium flow; steam } \\
\text { pressure } \\
\text { Primary sodium flow; reactor inlet } \\
\text { sodium temperature } \\
\text { Primary sodium pump speed } \\
\text { Feedwater valve }\end{array}$ \\
Attemperator valve & Steam temperature to turbine \\
Turbine admission valve & Plant output \\
\hline
\end{tabular}

During shutdown periods, reactor afterglow heat removal is normally accomplished by dumping steam to the atmospheric boiler under control of the backup pressure regulator. During startup, diverting steam to the atmospheric boiler is the simplest method of control until the superheated steam temperature is at a desirable level for starting the turbine. When steam pressure is abnormally low, the turbine initial pressure regulator automatically limits the turbine load to prevent a further pressure decrease.

\section{PROT ECTIVE SYSTEM}

The reactor protective system is provided to reduce reactor power level automatically when an off-normal condition is detected in the reactor. Off-normal conditions could originate from any of several causes, including the following:
a) Failure of the plant control system
b) Improper operation of a component while on manual or semiautomatic control
c) Failure of a system component 


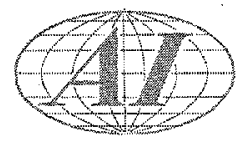

In the event of an off-normal condition which is of such severity that its continuation could cause damage to any part of the reactor plant, the protective system takes corrective action automatically. The corrective action can be in the form of reducing reactor power or scramming the reactor.

1. Protective System - Design Emphasis

Safety and reliability are the two prime considerations in the design of the protective system. Because excessively complex safety systems can reduce the reliability of the plant, a balance is sought which ensures adequate safety while minimizing power losses from shutdowns or setbacks caused by false (spurious) signals.

Some of the important safety features incorporated into the protective system are:

a) Fail-safe circuits and equipment wherever possible

b) Duplication of circuitry, so that failure of any one circuit leaves one or more other circuits intact and operable

c) Backup circuits using entirely different types of sensing elements.

Reliability of the protective system is maintained in several ways. Highly reliable individual components and coincident circuitry are used for the source of shutdown signals. Testing and monitoring systems determine proper operation of the protective system circuitry where possible. Several different types of protective system action are employed. In these ways, plant outages are reduced to a minimum, and yet adequate safety is maintained.

Coincident circuitry is used for the source of all power setback and scram signals except the manual and period signals. Generally, three sensing instruments are used to monitor any given variable which, if abnormal, would require corrective action. Corrective action is not taken unless at least two of the three sensing instruments simultaneously give abnormal signals.

Though each circuit is fail-safe, the signal given by the failure of a single circuit in a coincident circuit arrangement merely causes an alarm. The malfunction-detection circuit then actuates the appropriate annunciator. This alarm 


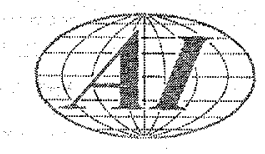

action permits remedial action without loss of plant output when a single circuit failure occurs. A failure or abnormal signal on either of the remaining two circuits would then cause automatic corrective action.

Manual signals to initiate any form of power reduction may be accomplished with a single signal. This permits the operator to manually reduce power. The period circuits are not on coincident circuitry because they are intended for protection during startup rather than for protection during extended normal power operation; and these circuits are made inoperative in the normal operating power range. Coincident circuitry is thereby limited to circuits which normally function continuously at all power levels.

The testing and monitoring system is used to make regular checks on the complete functioning of the circuitry in the protective system. Error detecting circuits indicate any failures or uns afe conditions.

\section{Protective System Description}

A block diagram of the protective system is shown in Figure 24. The system consists of the circuits which initiate corrective actions plus circuits for functional testing, monitoring, and malfunction detecting within the protective system.

The types of protective system action taken in the event of off-normal conditions are alarm, power setback, and scram.

a. Alarm

Alarm annunciators, which do not initiate automatic corrective action, are provided to warn the operator whenever an important reactor variable reaches an off-normal condition. Included are warnings from reactor auxiliary systems as well as from the principal reactor systems.

Each alarm consists of an audible annunciator and a visual indicator, the latter indicating which variable is not within its normal operating range. The operator must acknowledge each alarm signal by pushing an appropriate button to silence the audible signal. This leaves a visual indication of the off-normal condition until it has been corrected. 


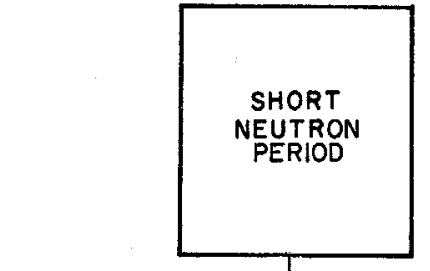

aUtOMATIC CHANNEL 3 CUTOUT

$1 \%$ FULL

POWER
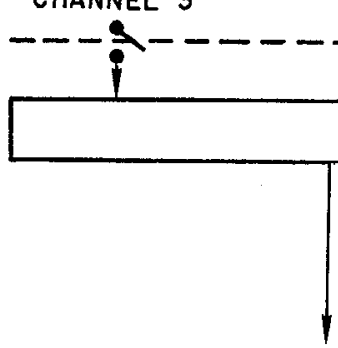

SHIM-REGULATINGDOWNDRIVE

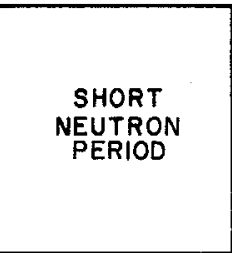

CHANNEL
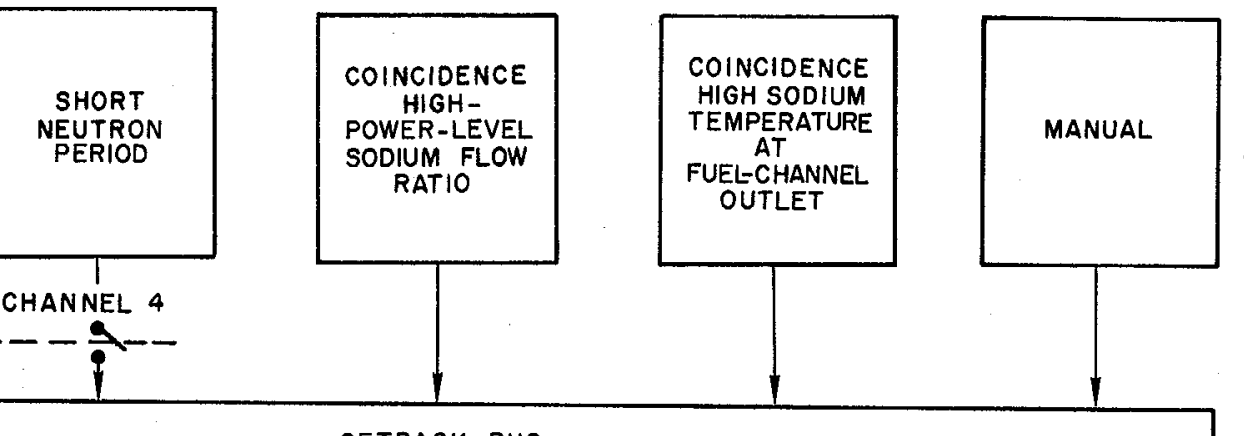

HIGH -

POWER - LEVEL

RATIO

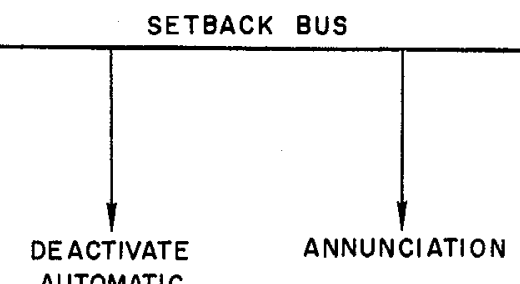

AUTOMATIC

NEUTRON

ANNUNCIATION

CONTROL

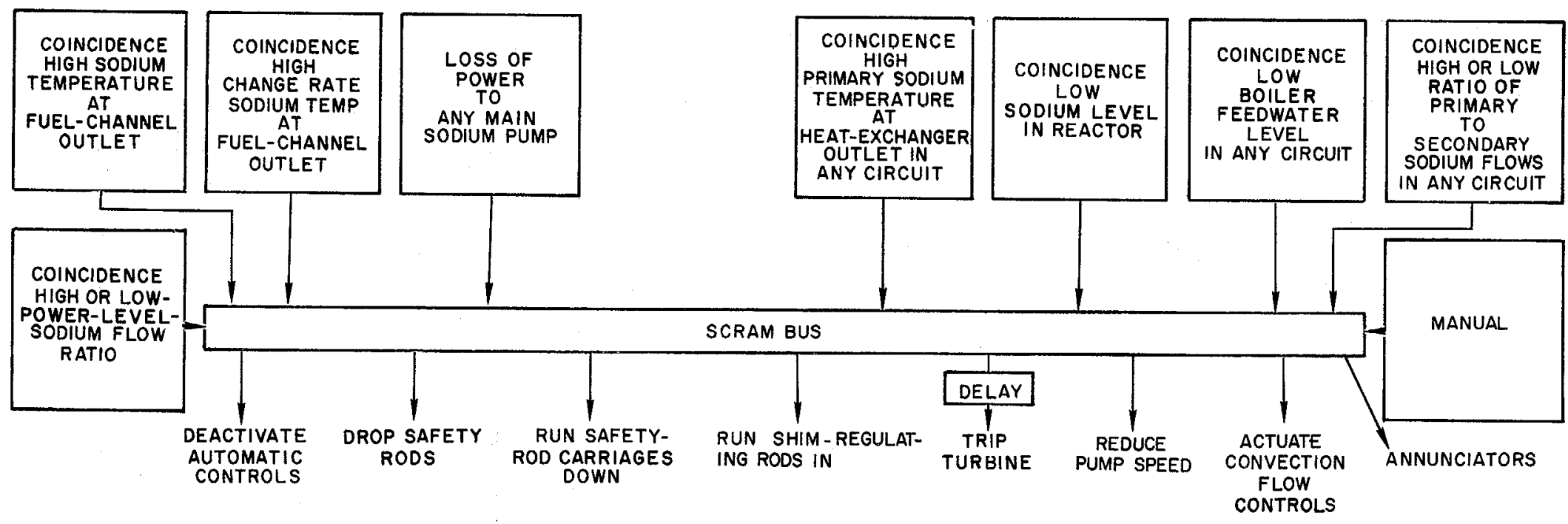

Figure 24. Protective System 
All signals which may cause automatic corrective action (setback or scram) have alarms associated with them. In most cases, an alarm set point is established so that the alarm sounds before the set point for automatic action is reached. The alarm warning generally allows the operator time to make any necessary manual correction, so that automatic action is not required.

Automatic corrective action is provided for those situations in which the operator does not have time to act, or fails to act properly, in response to an alarm signal. Automatic action is accompanied by additional alarms which indicate the type of action taken and the off-normal variable which required the action. The alarm system is further arranged to give the operator a signal as to which off-normal condition first occurred to cause the automatic action, even though several variables may be shown to be out of the normal operating range following the automatic action. When automatic action is initiated, an additional audible annunciator makes a noise appreciably louder than the other protective system alarm annunciators.

\section{b. Power Setback}

Any off-normal condition arising as a result of changes in reactor power level, coolant temperature, or coolant flow must be corrected before reactor temperatures, or rates of change of temperatures, become excessively high. The setback is intended to correct any off-normal conditions in the reactor itself without a complete shutdown and without introducing the possible rapid thermal transients associated with a reactor scram. The variables and necessary conditions for initiating a setback are listed in Table IX.

\section{TAB LE IX}

\section{POWER SETBACK}

\begin{tabular}{l|c}
\hline \multicolumn{1}{c|}{ Variable } & $\begin{array}{c}\text { Condition of Variable to } \\
\text { Initiate Power Setback }\end{array}$ \\
\hline $\begin{array}{l}\text { Ratio of reactor power level to } \\
\text { sodium flow rate }\end{array}$ & High \\
$\begin{array}{l}\text { Sodium temperature at fuel } \\
\text { channel outlet }\end{array}$ & High \\
$\begin{array}{l}\text { Reactor period } \\
\text { (during startup only) }\end{array}$ & Short \\
Manual setback & Button depressed \\
\hline
\end{tabular}




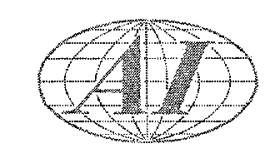

The setback is initiated whenever a condition causing high powerflow ratio, or high sodium temperature, increases in severity above a preset upper limit. Setback action automatically lowers the shim-regulating rods, thereby reducing reactor power. Power reduction is continued until all conditions requiring a setback are corrected.

A signal which represents an unbalance between reactor power level and sodium flow rate is a measure of the inability of the coolant to remove the proper amount of generated heat. A setback is initiated when power is disproportionately higher than flow.

Though the power-flow ratio circuit is intended to anticipate temperature changes and act first to reduce power level, the setback initiated by high sodium outlet temperatures serves as a backup to prevent potential thermal shock. The temperatures are obtained from special fast-response thermocouples measuring exit sodium temperatures in selected representative fuel channels.

A setback may be initiated by either of two period channels in the event of an excessively rapid rate of rise of thermal neutron flux during reactor startup. Except at the low power levels, power-flow ratio and temperature scram circuits are adequate protection against damage from a rapid rate of power rise. A potential source of unnecessary scrams, because of false instrumentation signals, is eliminated by not using the period circuitry during normal operation in the power range.

\section{c. Scram}

An automatic reactor scram is a rapid shutdown action, resulting in insertion of all control rods into the reactor core. It is only initiated if all other automatic measures of the plant protective system should fail to correct a condition which is potentially dangerous to the plant and to personnel. The reactor may be scrammed manually if the operator is not satisfied that a serious condition is being adequately corrected. 
The most rapid shutdown action of a scram comes from gravity fall of all safety rods into the core. In addition, rod motor drives automatically act to lower all shim-regulating rods and all safety rod drive mechanisms into the core. Either the safety rods or the shim-regulating rods could independently remove all excess reactivity from the reactor (section $\mathrm{XI}$ ), but for extra security both sets of rods are inserted during a scram.

The variables and necessary conditions for initiating a reactor scram are listed in Table $X$. Power-flow, ratio, and temperature scrams are preceded by alarm and power setback to permit operator action or power setback action before a scram occurs. In the cases of trouble in any sodium circuit (pump failure, low evaporator water level, sodium flow unbalance, high reactor inlet temperature), the reactor is scrammed immediately without prior setback action.

\section{TABLE X}

REACTOR SCRAM SIGNALS

\begin{tabular}{ll}
\hline \multicolumn{1}{c}{ Variable } & \multicolumn{1}{c}{$\begin{array}{c}\text { Condition of Variable to } \\
\text { Initiate Scram }\end{array}$} \\
\hline $\begin{array}{c}\text { Reactor power level sodium flow } \\
\text { ratio } \\
\begin{array}{c}\text { Sodium temperature at fuel } \\
\text { channel outlet }\end{array}\end{array}$ & High or low \\
$\begin{array}{l}\text { Electric power to primary or } \\
\text { secondary sodium pump }\end{array}$ & High or high rate of change \\
$\begin{array}{l}\text { Primary sodium temperature at heat } \\
\text { exchanger outlet }\end{array}$ & Loss (signal is delayed) \\
$\begin{array}{l}\text { Sodium level in reactor } \\
\text { Evaporator water level } \\
\text { Ratio of primary to secondary } \\
\text { sodium flow }\end{array}$ & High (in any circuit) \\
Manual scram & Low \\
\hline
\end{tabular}

Generally, the reactor power-sodium flow ratio scram is prevented by a setback initiated by the power-flow ratio or by operator action prior to reaching the scram set point. The scram set point is established so that the 


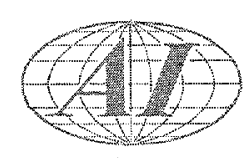

reactor will shut down in time to prevent damage in the event reactivity, sodium flow, or inlet temperature exceed preset limits. Time delay in these circuits is minimized.

Thermocouples measuring exit sodium temperatures from selected representative fuel channels are used to initiate a scram before temperatures in the reactor could become high enough to cause severe overheating of components. Normally, the action taken by the power-flow ratio setback circuit or by the operator would prevent sodium outlet temperatures from becoming as high as the temperature set point for a scram; the high temperature scram merely serves to back up the setback system and the power-flow ratio scram in case these should fail to act to correct a reactor disturbance. These same thermocouple signals are also used to activate a scram if the sodium temperature is changing too rapidly. Scram action from this cause acts as a back-up signal when the reactor is operating at a reduced temperature level (below design temperature level); and acts also to protect the reactor against potential thermal shock in the event of a mis-match between reactor power and sodium flow rate (which could cause rapid increases or decreases of the coolant temperature).

Loss of power to any of the sodium pumps results in a scram. There is a time delay incorporated in this circuit to avoid scrams due to electric power losses which are brief enough to cause no damage to the reactor. The scram from loss of electrical power normally precedes the signals which would initiate a scram caused by low sodium flow or high fuel channel temperature. The scram action protects reactor components from severe overheating and thermal stress which could occur if pumps should fail to function because of a sustained loss of electric power.

The scram initiated by high primary sodium temperatures at the heat exchanger outlet protects the reactor against thermal damage and reactivity changes caused by a malfunction in the heat exchanger, steam generator, primary flow control system, or secondary flow control system.

If a major leak in the primary sodium system were allowed to lower the reactor sodium level to the extent that the exit lines between the reactor and the primary pumps were pumped dry, no further reactor cooling from natural convection flow through the primary loops would be possible. To prevent this 
situation from developing, the reactor sodium low level scram is set well above the danger point. The scram reduces the speeds of the sodium pumps, thus preventing rapid core pump-out.

The evaporator water level circuit detects off-normal conditions in the steam system; the low level scram protects against potential damage which could be caused by drying of the evaporator due to a failure in the feedwater system or in the evaporator itself.

An unbalance in the ratio of primary to secondary sodium flow rates is usually the first indication of failure of a sodium pump or sodium flow controller and is used to initiate a scram.

When a scram occurs, the immediate and most important action is the dropping of the safety rods into the core to make the reactor subcritical. Simultaneously, however, other automatic actions are initiated to shut down the plant in an orderly and safe manner. The shim-regulating and safety rod drives are run into the core and the neutron flux controller is deactivated. The sodium convection flow controller is actuated to control the removal of afterglow heat by operating the throttling valves in each loop. The main sodium pump motors are reduced in speed. The cause of the scram is registered on the scram annunciator as an aid in locating and correcting the difficulty as rapidly as possible. After a suitable time delay, the turbine is tripped and steam is then automatically diverted to the atmospheric boiler.

\section{E. RADIATION MONITORING SYSTEM}

A radiation detection and monitoring system (Figure 25) is provided for: (1) protection of personnel; (2) indication of off-normal conditions; and (3) prevention of the release of excessively radioactive material to the plant environs.

A six-channel remote area monitoring system is provided for monitoring radiation levels at various locations throughout the plant. This installation provides beta-gamma monitoring in areas routinely occupied by operating personnel and gamma monitoring in areas of higher radiation level that are infrequently occupied. Each channel is recorded and give an audible alarm should radiation levels become excessive. 


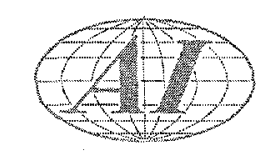

Five airborne particulate monitors are provided for monitoring the radioactivity of particulate matter at various locations within the reactor building. Each monitor is equipped with a recorder. An audible alarm would be actuated should radiation levels become excessive.

An eight-channel radiation monitoring system is provided for monitoring the radiation level of the nitrogen atmosphere used for blanketing and cooling the sub-grade tunnels and cells containing radioactive sodium. Each channel is recorded. An audible alarm is given should radiation levels become excessive.

A three-channel radiation monitoring system is provided for monitoring the radiation level at the surface of the secondary sodium piping exterior to the biological shield. Audible alarms are given should the radiation level become excessive.

A single-channel radiation monitoring system is provided for monitoring the radioactivity of liquid waste being discharged from the liquid decay tanks to the sewage system. This radiation level is continuously recorded. An audible alarm is sounded if the radiation level becomes excessive and at the same time automatic control action is initiated to stop the release of liquid waste.

A two-channel radiation monitoring system is provided for monitoring the radiation levels of the nitrogen system vent and other normally nonradioactive gases flowing to the effluent stack. Should the radiation level become excessive, automatic control action is initiated and the gases are diverted to the radioactive vent system.

A pre-stack monitor and a stack gas monitor are provided for monitoring the radioactivity of effluent gas being released to and by the stack. These radiation levels are continuously recorded. Should the radiation level of the effluent gas become excessive, audible alarms are given. If the plant operators cannot take corrective action, and if the radiation level rises to a point which would present a potential contamination hazard, automatic control action is initiated and the release of effluent gases is stopped. 
The heat transfer system associated with the reactor, as described in the preceding section, transfers energy from the reactor to the steam turbine. In addition to this system, auxiliary systems are required to provide all the plant services necessary for the proper functioning of the plant.

In addition to the sodium service system which facilitates the safe handling of sodium, there are also separate systems for each of the auxiliary coolants (tetralin and water) and the inert gases (helium and nitrogen) used in the plant operations. A radioactive vent system and a radioactive liquid waste system are provided to control the disposal or storage of any potentially radioactive gases or liquids. The electrical power supply system for the plant ensures the supply of power where needed during normal and abnormal conditions.

\section{A. SODIUM SER VICE SYSTEM}

The functions of the sodium service system (Figure 26) are the filling, draining, and flushing of the sodium heat transfer loops and the purification of the sodium. The system consists of the melt stations for new sodium, the primary and secondary fill tanks, the electromagnetic fill and service pumps, and the plugging meter and cold trap equipment for sodium purification. All piping and equipment which come in contact with sodium can be preheated to $350^{\circ} \mathrm{F}$. Helium and vent connections are provided to purge the air from the system before admitting sodium.

1. Filling

Two sodium melt stations are provided for system filling. One station can accommodate the tank car in which sodium is received for the initial filling operation. The other station can accommodate two 55-gal drums and is used for system makeup. The tank car sodium is melted by a hot oil circulating system and then the sodium is transferred by the electromagnetic fill pump from the tank car, through filters, to either the primary or secondary fill tanks. Makeup sodium in the 55 -gal drums is melted by electrical heating. The liquid sodium flows by gravity from the drums to the sodium transfer tank. From here, it is transferred by the fill pump, through the filters, to either set of fill tanks. 


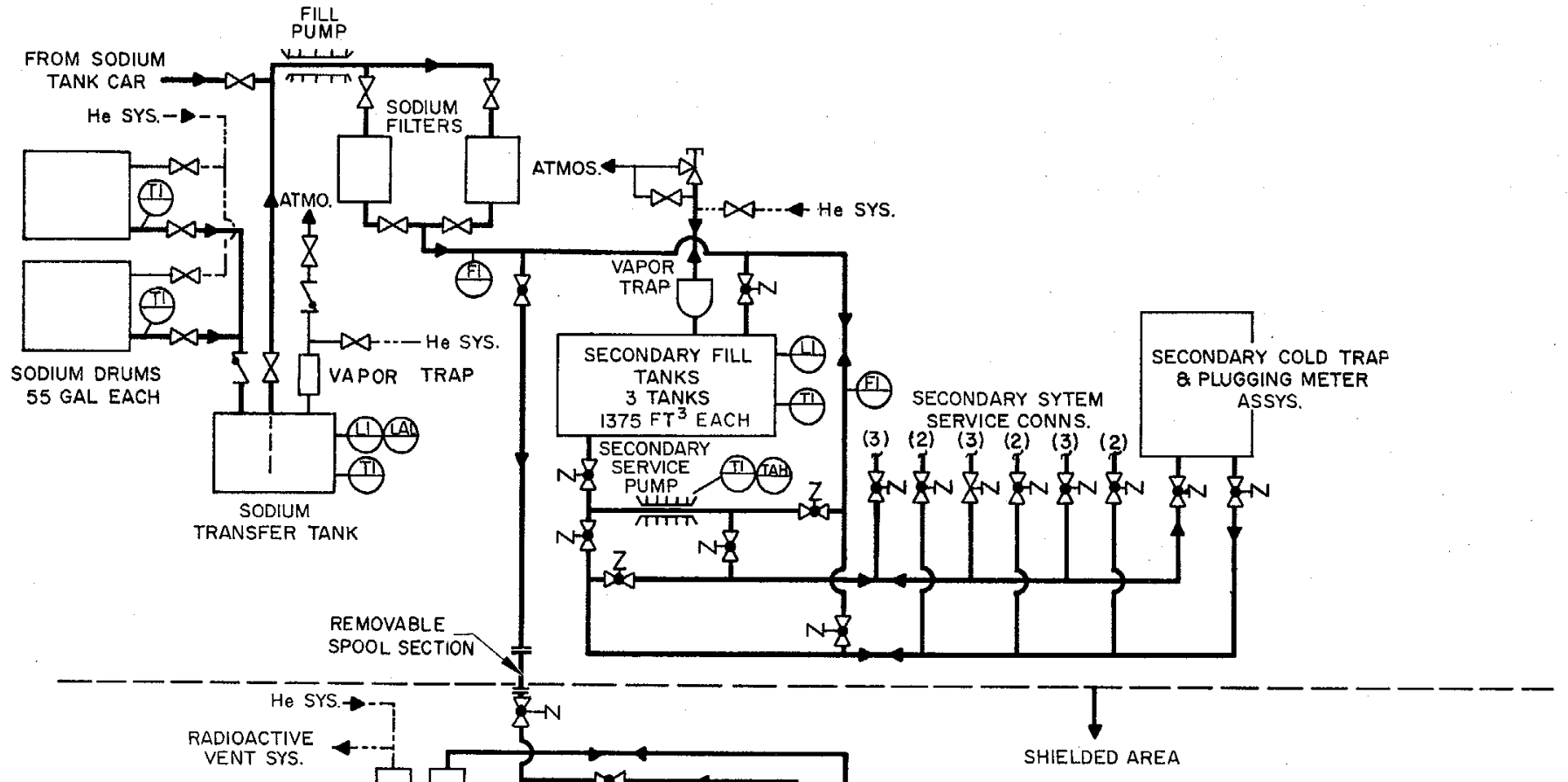

$\infty$

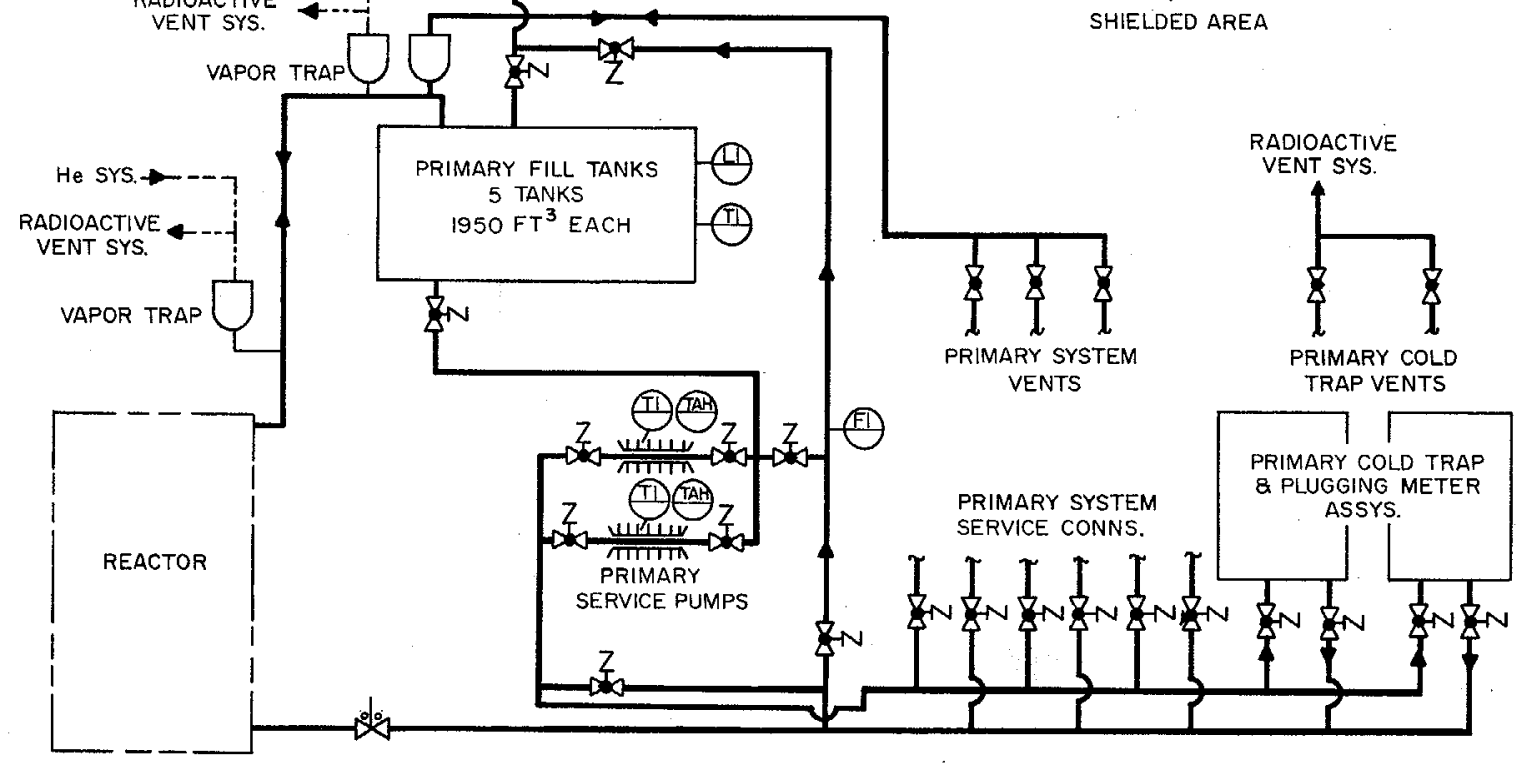

Figure 26. Sodium Service System 
Once the primary fill tanks are completely filled, a spool section is removed from the fill line, and the line is closed off to eliminate the possibility of radioactive liquid sodium (or vapor) entering the secondary fill tanks.

The shell sides of the sodium heat exchangers are filled first because the passages in the shell side are less likely to plug (with solidified sodium) than are the tubes. Also, the tubes would be difficult to preheat with only helium on the shell side. The steam generators are preheated by introducing steam into the shells.

The secondary loops are normally filled by using the electromagnetic secondary service pump. The loops can also be filled by pressurizing the secondary fill tanks. Each loop is filled to a predetermined expansion tank level. Helium atmosphere is maintained over the free surfaces of the sodium in the expansion tanks at all times and the tanks are vented to atmosphere through individual vapor traps and relief valves.

The reactor vessel and the primary heat transfer loops are filled by a combination of gravity flow and pump power. At the point where gravity flow will no longer fill the loops, the primary service pumps are used to finish the operation.

There are five primary fill tanks located in a shielded cell in the sodium service area. Only four tanks are required to contain the total sodium volume in the reactor core and the primary loops; the fifth tank is provided to contain fresh sodium for system flushing. The primary fill tanks are manifolded to the two primary service pumps so that the sodium can be cold-trapped before it is admitted to the reactor vessel and the primary loops.

Each primary loop high point, which is at the top of the intermediate heat exchanger, and the high points in the cold trap piping are vented through freeze traps to prevent liquid sodium from entering the vent and helium systems. A freeze trap is essentially a hollow metal cylinder installed in the vent line. During the filling operation, it is cooled by the local atmosphere to below the melting point of sodium. As the system is filled, gas escapes through the freeze trap and the vent line. When the system is filled and sodium rises into the trap, the sodium freezes in the cylinder, forming a solid plug which seals the vent line. When it is necessary to open the vent line, the frozen sodium is melted by heating the cylinder. 


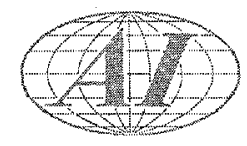

The reactor vessel and the primary fill tanks share a common vent header so that a gas balance is maintained during the filling operation. Also, the vent line from the high-point freeze traps on the intermediate heat exchangers ties into this vent header through a vapor trap. The function of the vapor trap is to prevent sodium vapors from entering the freeze trap vent line. This makes it unnecessary to heat this line.

\section{Draining}

The sodium in the reactor vessel and in the primary loops can be drained to the primary fill tanks using either of the primary service pumps. The service pumps are at approximately the same elevation as the top of the graphite in the reactor core. Once the sodium level in the reactor vessel has been lowered to this point, the draining of the tank must be completed in one continuous operation to maintain pump suction.

The primary loops can be drained either all at once or one loop at a time. Each loop has two drain lines connected at the low points in the piping next to the blocking valves. To drain an individual primary loop, the blocking valves must be closed and the sodium must be melted out of the high point freeze traps to allow helium venting during the draining operation.

The secondary loops can be drained to the secondary fill tanks using the secondary service pump. Each of these loops has three drain lines connected at the low points in the piping.

Each secondary loop is equipped with a radiation monitor which actuates an alarm circuit. A secondary loop could become radioactive if there is a leak in the intermediate heat exchanger and the helium pressurizing system fails in the secondary loop. Depending on the extent of the leak, and the radioactivity level in the secondary loop, two courses of action may be taken. If the radioactivity level were low, the primary loop could be isolated and the flow control value in the secondary loop closed (to minimize natural convection), while the radioactivity level decayed. If the radioactivity level in the secondary loop were high, it would be necessary to replace the removable spool piece and pump the sodium from the secondary loop to the primary fill tanks. 


\section{Flushing}

At infrequent intervals it may be necessary to flush the radioactive contaminants from a primary loop so that an equipment cell can be entered. Nonradioactive sodium is normally stored in one of the primary system fill tanks for this purpose. The flushing operation consists of alternately filling the loop with nonradioactive sodium and draining it to one of the other primary fill tanks. This can be accomplished several times with the amount of sodium stored in one fill tank. Eventually, it may be necessary to dispose of some of the flushing sodium. This can be done through the removable spool section in the fill line.

\section{Sodium Purification}

The purification equipment in the sodium service system consists of two primary and one secondary circulating-type cold trap and plugging meter assemblies. The function of the cold trap is to remove sodium oxides from the sodium. This is accomplished by cooling the sodium to a point where the oxide becomes insoluble and precipitates out. In the cold trap, the sodium is cooled by tetralin which circulates in an enclosing jacket. The sodium then passes through a wire mesh which filters out the oxide precipitates. The entire cold trap can be replaced when necessary.

The plugging meters are provided to indicate the oxide concentration. A plugging meter consists of an orifice, a sodium cooler (cooled by circulating tetralin), and temperature and flow meters. As the temperature of the sodium flowing through the orifice is decreased, a point will be reached where the oxide precipitates out and begins to plug the orifice. The oxide concentration is determined by comparing the temperature and flow values with a plot of saturation temperatures for sodium oxide in sodium.

Two primary cold-trap units are furnished so that one unit can be in operation while the other is being serviced. Each primary unit is located in a separate concrete vault below grade level, making one unit accessible while the other is operating.

The sodium service piping is arranged so that sodium can be cold-trapped from either the fill tanks or the individual loops. Normally, cold-trapping from the fill tanks would be done only prior to filling the system. In this operation, sodium is transferred from the fill tank by a service pump, through a cold-trap, 


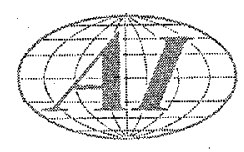

and back to the same fill tank. During power operation of the heat transfer system, one primary loop and one secondary loop may be cold-trapped at a time. A small sodium stream is bled from the discharge side of the main sodium pump, sent through the cold-trap, and returned to the main system on the suction side of the pump. To check the oxide concentration from time to time, the sodium can be diverted from the cold-trap to the plugging meter.

\section{B. ORGANIC COOLING SYSTEM}

The organic cooling system (Figure 27) provides cooling for the reactor loading face shield, and for sodium-system components in which a coolant leak could result in a reaction with sodium. Tetralin, which is chemically compatible with sodium, is used as the coolant. A nitrogen atmosphere is maintained in the system to keep water vapor out and thus minimize corrosion.

The organic system consists of two organic-to-water heat exchangers, a storage tank, two pumps for normal operation, one pump for emergency operation, and the necessary instrumentation and piping for control and distribution of the coolant. The various components to be cooled are fed from two parallel headers.

During normal operation, the coolant is pumped from the storage tank, through the headers, through the cooling loads (freeze seals, cold traps, etc), through the heat exchangers, and back to the storage tank. In the heat exchangers, the organic liquid is cooled by circulating water from the cooling towers. One of the two organic coolant pumps supplies coolant to the entire system. The second pump is actuated by a pressure controller installed in the discharge line of the pump in service. The second pump is put on the line when the discharge pressure of the pump in service falls below the operating minimum. The organic cooling system temperature gradients depend on the cooling loads, themselves. The organic coolant pumps are constant speed, and temperature controls are maintained by means of temperature control valves or throttle valves in the coolant discharge lines of the components.

The components which are cooled by the organic system can be divided into two groups: (1) those which can tolerate some temperature increase and, therefore, slight interruptions in coolant flow, and (2) those which must be constantly cooled and require uninter rupted coolant flow. In this latter group are sodium 


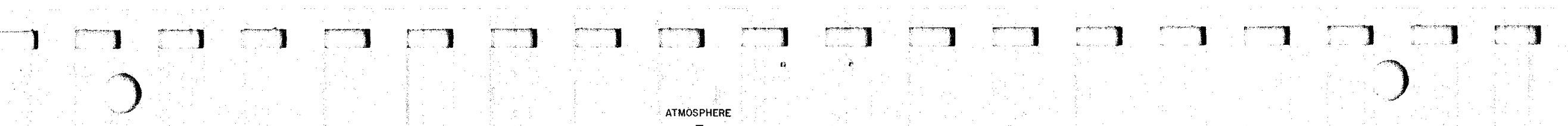

$\infty$
0
$\infty$
$\infty$

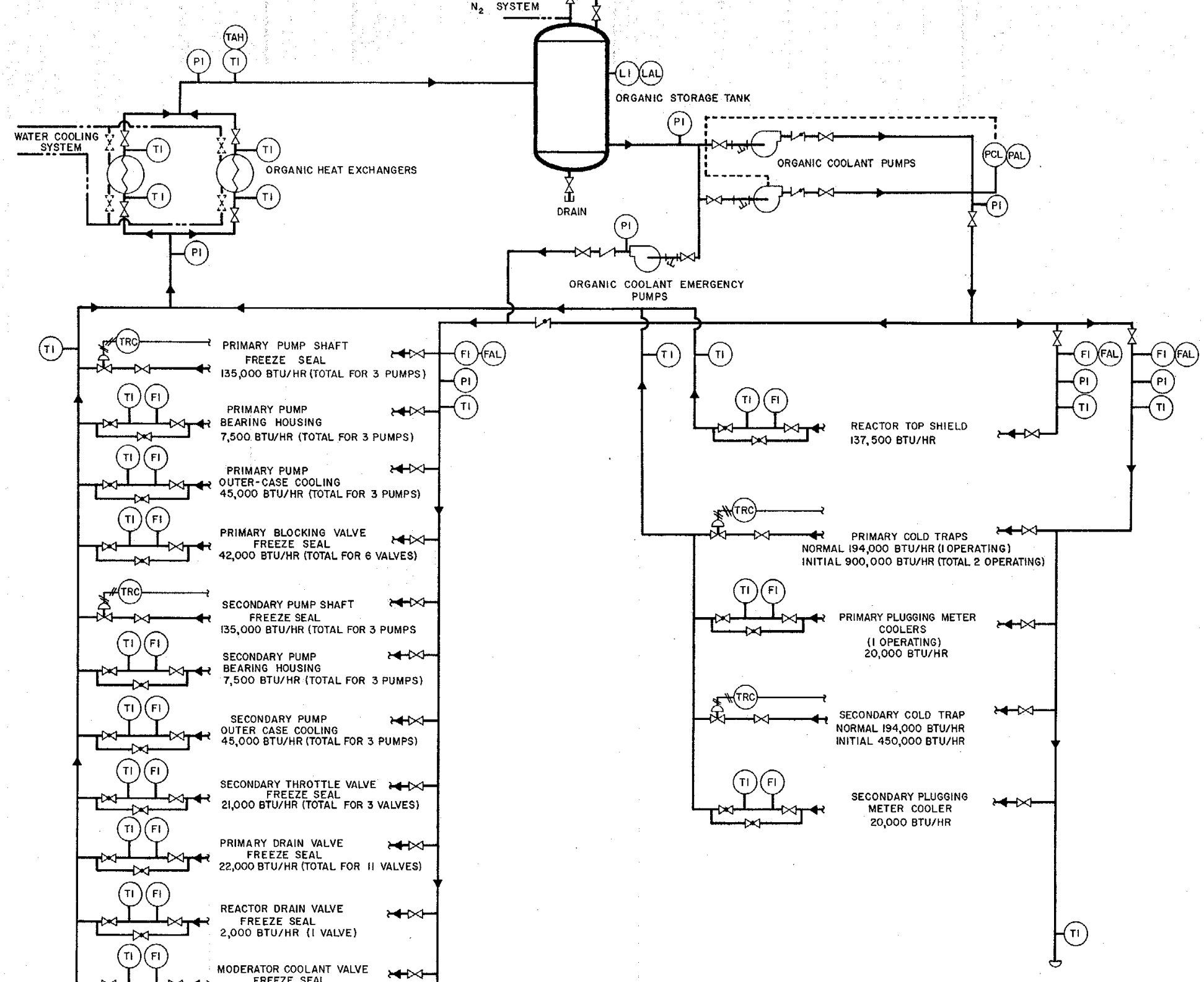




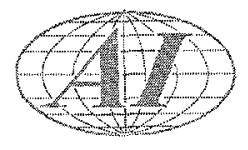

pump shaft and case freeze seals, sodium pump bearings, and sodium valve freeze seals. Overheating at these points would cause failure of the component. To insure continuous coolant flow to these units; an emergency pump, operated from a battery power source, is immediately available in the event of a power failure to the regular pumps. A check valve prevents coolant flow to those components which do not need this emergency service. In the electrical power system, a diesel generator is available to supply power to certain "vital" components, including the regular organic pumps, in case the normal power supply fails. The regular pumps come back into service as soon as the diesel-generator is put on the line.

\section{WATER COOLING SYSTEM}

The water cooling system (Figure 28) provides auxiliary cooling in those components and areas in which there is no potential danger of contact between the water and sodium. The water cooling system consists of two separate closed circuits. Circuit 1 services equipment in areas where radiation is present. Circuit 2 services the cell atmospheres, the organic-system heat exchangers, and the circuit-l heat exchangers. The components and areas which are cooled by the water system are shown in Figure 28.

Circuit 1 includes two 150 -gpm pumps and two shell-and-tube, water-towater heat exchangers. The two pumps are connected in parallel and each has sufficient capacity to handle the normal circuit requirements. The heat exchangers are also connected in parallel and each has a heat dissipation capacity of $4 \times 10^{6} \mathrm{Btu} / \mathrm{hr}$. In normal operation, the pumps draw suction from the coolant pools surrounding the fuel storage cells and circulate the water through the heat exchangers to the various cooling loads. Discharge lines from the cooling loads return the water to the fuel storage cell pools. The temperature decrease of the circuit 1 water in the heat exchangers is from approximately 150 to $95^{\circ} \mathrm{F}$. The corresponding temperature increase in the circuit 2 water is from 85 to $105^{\circ} \mathrm{F}$. The coolant flow through each load is established by means of manually adjustable valves in the inlet line. Cooling in the fuel cleaning cells and the equipment cell is periodic and is normally required when the reactor is shut down and reactor cooling requirements are at a minimum. 


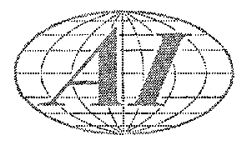

Circuit 2 includes two 750 -gpm pumps for normal operation and a battery operated, 50-gpm pump for emergency operation in case of power failure. This circuit cools the cell atmospheres, the circuit 1 heat exchanger, and the organic system heat exchanger. Heat is dissipated from the circuit in the auxiliary cooling tower.

In case of electric power failure, the battery-operated emergency pump starts up immediately and supplies cooling water to the organic system heat exchangers. The organic system must be continuously cooled because it, in turn, services the sodium freeze seals and pump bearings which require uninterrupted cooling. A check valve prevents the emergency flow from going to loads other than the organic system heat exchangers.

\section{HELIUM SYSTEM}

The helium system (Figure 29) maintains an inert gas atmosphere in the reactor and in piping and equipment in contact with sodium. Its principal functions are to maintain constant helium pressures in piping and equipment which it services and to provide for purging the system or part of the system. The helium system consists of a supply manifold, a pressure-control unit, a NaK bubbler for purification, a low-pressure storage tank, and pressure controllers for providing constant helium pressures to the various components.

Helium is supplied by a duplex supply manifold having ten 225-scf bottles connected to each side. The control unit reduces the pressure of the helium leaving the manifold and sends the gas through the NaK bubbler to the storage tank on demand.

The control unit reduces the helium pressure to $50 \mathrm{psig.} \mathrm{The} \mathrm{unit} \mathrm{is}$ designed so that when the pressure from one bank of 10 bottles drops to 50 psig, the operating controller shuts off. When the helium system pressure in the storage tank drops to 45 psig, the other controller opens to the other bank of 10 bottles. Low pressure alarms indicate when these actions take place. The manifold valves must then be manually changed so that the helium is rerouted to the original controller. The empty bottles can then be replaced.

The NaK bubbler consists of a series of NaK-filled cylinders which remove oxygen from the helium. Traps are arranged between the cylinders to prevent a carryover of $\mathrm{NaK}$ into the helium system.

VI -10 



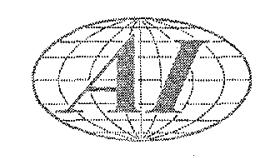

During normal operation, the pressure controllers throughout the helium gystem maintain constant pressures on the components which they supply. The helium pressure in the primary sodium system is maintained at 1 to 6 in. $\mathrm{H}_{2} \mathrm{O}$, and in the secondary system at about twenty psig. The valve and pump freeze seals are kept at about 2 psig to insure an inert atmosphere above them. The helium in the wash cells and in the pickup, disconnect, and moderator loading cells is kept at 0.25 psig. The control rod thimbles are maintained at 15 psig, and the high point freeze traps and secondary fill tanks are maintained at sufficient pressure to allow for transferring and draining of sodium from the secondary loops.

All helium lines which service radioactive systems or components are equipped with check valves to prevent radioactive gas from escaping to the atmosphere in the event of a rupture in a helium supply header. Each pressure controller is provided with a bypass line through which higher pressures can be applied if required for purging or pressure-transferring. Throttle valves in the bypass lines are used to control flow and pressure. Relief valves prevent overpressurization. The relief valves are connected either to the radioactive vent system or to the atmosphere, depending on whether or not they might release radioactive gases. Locked-open blocking valves are installed on all lines between the relief valves and the equipment; these can be closed to test the relief valves.

Helium can be used for transferring sodium between the fill tanks and the heat transfer loops if the service pumps are not available. The helium pressure controllers to the secondary loops are rated at about twenty psig, which is sufficient to accomplish the transfer. In the primary loops, the pressure controllers must be bypassed during the transfer operation.

During draining of the sodium loops, helium is introduced at the high points in the system. The helium flow rate into the sodium system is determined by the sodium draining rate (which is approximately $100 \mathrm{gpm}$ ) and is dictated by the sodium service pumps. Helium is also vented into the cold-trap high points to allow these components to be drained to the point where they can be disconnected without losing sodium. The helium pressure controllers for this service are sized at 10 psig and 1 scfm. 


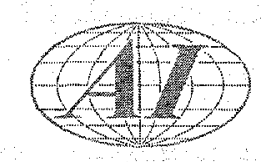

\section{E. NITROGEN SYSTEM}

The primary function of the nitrogen system (Figure 30 ) is to maintain an inert-gas atmosphere in the pipe and heat exchanger cells, the cold-trap cells, the primary fill tank cell, the moderator coolant pump cells, the maintenance cell, and the primary service pump cell. Nitrogen is also used as a cover gas in the organic cooling system to reduce water vapor and therefore minimize corrosion in the system. During the sodium filling operation nitrogen is used to maintain an inert atmosphere in the sodium tank car.

The nitrogen system consists of nitrogen supply trailers, a pressure control unit, a low-pressure storage tank, and a vent controller to divert flow either to the building vent stack or to the suction tank of the radioactive vent system. Also, each cell served by the nitrogen system has an inlet pressure regulating station, a radioactive dust (particulate) filter, and an outlet back-pressure regulator. The nitrogen is handled in three trailers of 20,000 to 40,000-scf capacity each. Two of these are connected to the system supply manifold, one on the line and the other as a standby, while the third is in transit. The supply manifold consists of two parallel pressure regulators and a valving arrangement which allows the gas from either trailer to be routed through either pressure regulator. The pressure regulator reduces the nitrogen pressure at the trailer valve $(2400 \mathrm{psig}$ when full) to $55 \mathrm{psig}$. When the trailer pressure drops below 55 psig, the operating regulator closes and the other regulator opens to the standby trailer. A low pressure alarm indicates that this action is taking place. It is then necessary to manually reset the manifold valves to direct the nitrogen flow back through the operating regulator. The empty trailer can then be replaced.

The nitrogen passes from the supply manifold to the $100-\mathrm{ft}^{3}$ storage tank and then to headers leading to the various cell inlet pressure regulators. The inlet pressure regulators are set at 1 in. $\mathrm{H}_{2} \mathrm{O}$; the back-pressure regulators are set at 6 in. $\mathrm{H}_{2} \mathrm{O}$. This pressure range is sufficient to maintain a positive nitrogen atmosphere and yet is not large enough to aggravate a leak or cause stress problems in the steel liners of the cells. 

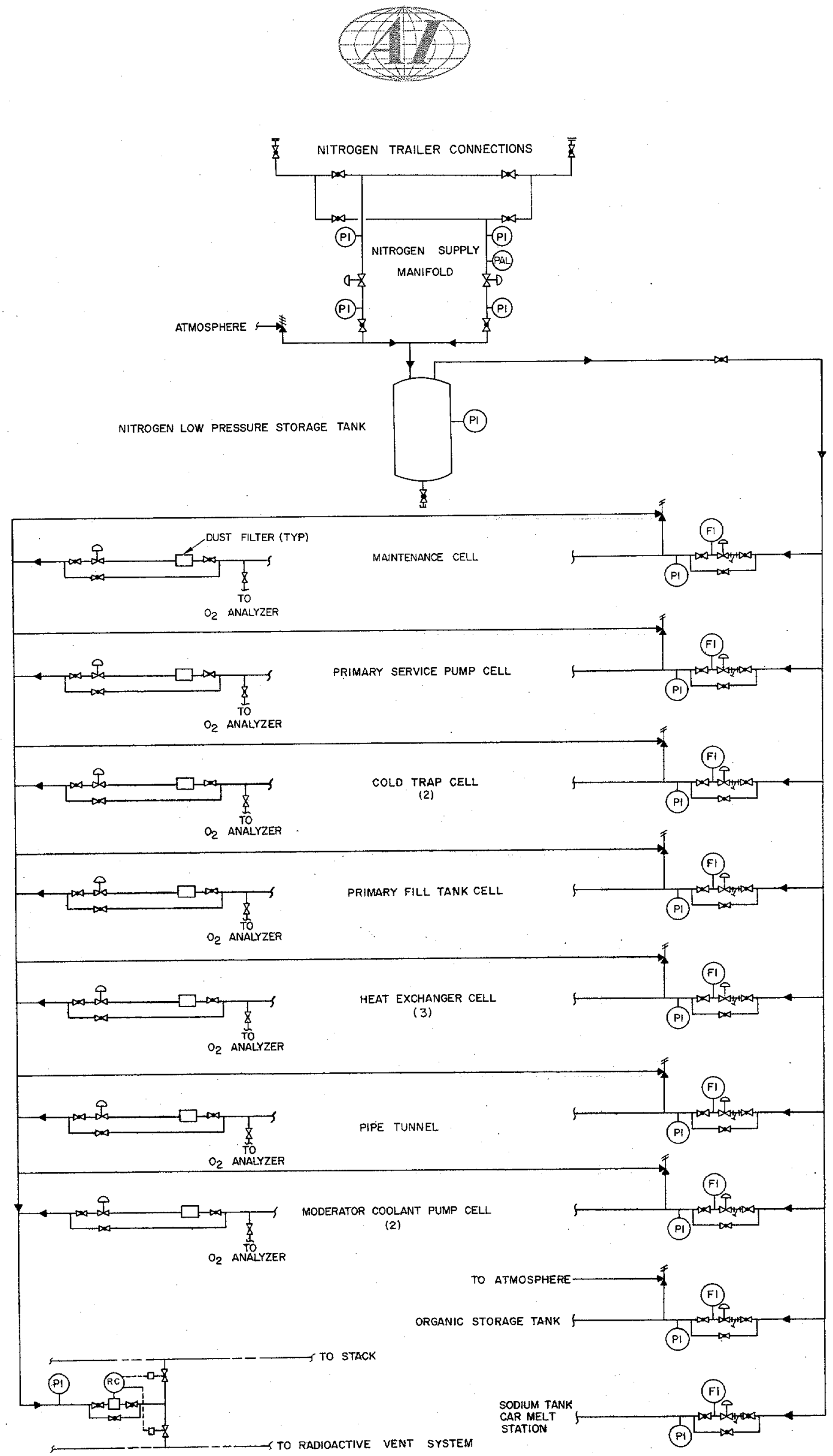


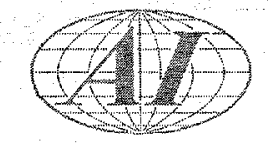

Relief valves in the cell inlet lines will open at 2 psig. Each cell is equipped with a filter to collect particulate matter which might be radioactive. The nitrogen atmosphere in each cell is recirculated through an individual water-cooled heat exchanger to maintain the desired temperature in the cell. The cells and primary pipe tunnel have $100 \%$ spare cooling equipment units to insure continuous cooling in case of an equipment failure. As the nitrogen is recirculated, it is monitored for radioactivity. Fire detectors are also installed in each cell as part of the plant fire detection system.

Sample lines from the cell outlet lines are manifolded to a local, boardmounted oxygen analyzer. The manifold valving arrangement is such that the cell atmospheres can be monitored collectively or individually. This permits continuous, collective monitoring during normal operation and, in case an excess of oxygen is detected, individual cell monitoring to locate the source.

At the system outlet, a radiation-sensitive vent controller monitors all effluent gases and, by operating two valves, automatically directs the gas flow either to atmosphere through the plant exhaust system or to the radioactive vent system.

In each cell, both the inlet and the outlet pressure regulators have bypass lines which are used during purging operations. The purge rate is controlled by throttle valves in the bypass lines. The oxygen analyzer can be used to indicate the effect of the purging operation. During reactor startup, after the cells have been purged and brought to the 1 to 6 in. $\mathrm{H}_{2} \mathrm{O}$ pressure, the back-pressure regulators handle the necessary nitrogen bleed-off in order to maintain constant pressures as the cells heat up.

After a reactor shutdown, the inlet pressure regulators maintain constant pressures as the cells cool down. The pressure regulating requirements during both heating-up and cooling-down periods are based on a cell temperature change rate of $15^{\circ} \mathrm{F} / \mathrm{hr}$.

\section{F. RADIOACTIVE VENT SYSTEM}

The radioactive vent system (Figure 31 ) is provided to control the disposal of any gas that might be radioactive. The gases collected by the radioactive vent system fall into two main groups: gases which are normally radioactive; and gases which are normally not but could become radioactive. The normally 


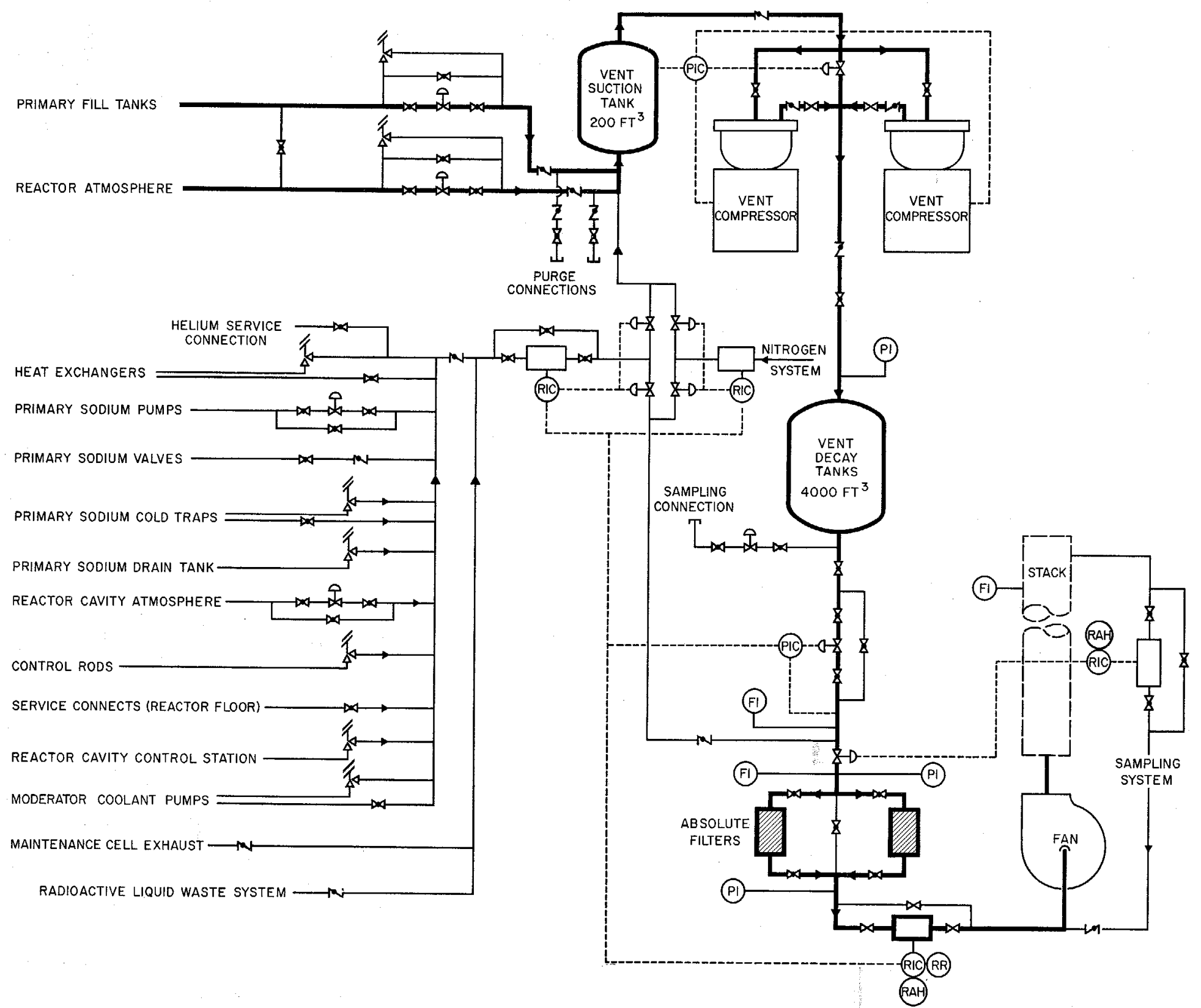

Figure 31. Radioactive Vent System 


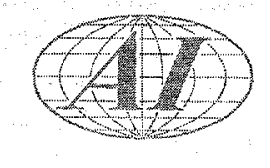

radioactive gases come from the reactor and from the primary fill tanks. These gases flow through pressure controllers into the vent suction tank. From here they are pumped into the decay tanks for storage and controlled disposal. The gases which are not normally radioactive flow through a radiation detector which directs them to a bypass line directly to the plant ventilation stack or through the vent suction tank and the compressors to the decay tank, depending on the radioactivity level.

Each compressor can pump gas at a rate of $25 \mathrm{scfm}$, which is sufficient to handle the maximum gas flow caused by either a maximum sodium system temperature increase rate of $50^{\circ} \mathrm{F} / \mathrm{hr}$ or by filling the sodium system at approximately $100 \mathrm{gpm}$. Two compressors are provided in the system to ensure continued operation if one compress or should fail so that it would have to be removed from service for maintenance. The compres sors are turned on and off by a pressure controller on the suction tank.

The four decay tanks have a volume of $1000 \mathrm{ft}^{3}$ each and can be pressurized to $150 \mathrm{psig}$. Radioactive gases are contained in these tanks until the activity level has decreased to the point where the gases can be released to the plant ventilation stack. During the decay period, the gases in the tanks are sampled and the decay pattern is charted. When the activity is low enough, the gases are released to the stack very slowly. The dilution rate is such that, assuming a total flow through the stack of 35,000 to $45,000 \mathrm{scfm}$, it is estimated that 7 to 10 days would be required to empty one of the $1000 \mathrm{ft}^{3}$ decay tanks.

The effluent gases are checked for radioactivity on the outlet side of the absolute filters. If the activity should exceed the permissible level, solenoidoperated valves are automatically closed in the lines from the decay tanks, from the normally non radioactive components, and from the nitrogen system.

As a final backup control, the stack gas is checked for radioactivity in a continuous sampling system. If the activity of the stack gas should increase to a set upper limit, the detector-controller sounds an alarm and automatically closes the valve on the inlet side of the absolute filters, completely shutting off the radioactive vent system from the stack. 


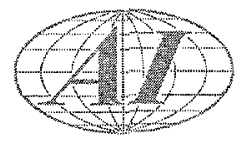

The decay tanks are sized to handle normally radioactive effluent gases and also to contain the gas which would be used to purge the reactor atmosphere before and after primary sodium draining. The reactor is purged by connecting the fuel handling cask above the top shield, removing the shield plug at that position, and blowing helium from the cask, through the reactor, to the radioactive vent system. Three purges of the core atmosphere before draining the sodium, and one purge of the primary sodium system after the draining will probably be required.

\section{G. RADIOACTIVE LIQUID WASTE SYSTEM}

The function of the radioactive liquid waste system (Figure 32 ) is to safely store all liquid waste materials which are, or might be, radioactive. The system consists of storage tanks, 'piping, and instrumentation.

Radioactive liquids come mainly from the fuel cleaning cell, the decontamination cell, the maintenance cell, and the laundry, and have widely varying degrees of activity. Two 5000-gal short-lived storage tanks are provided to hold liquids in which the activity will decay in a short time (30 days or less) to the point where disposal is possible. Two 10,000-gal long-lived storage tanks are provided for those radioactive liquids with longer decay period requirements. Two 2000-gal high concentration tanks are provided to contain highly radioactive liquids until they can be packaged for disposal.

The major portion of the radioactive liquid waste is generated during the fuel cleaning process. The handling of the wash water from the fuel cleaning cells depends on its radioactivity level. If no fission products are involved, the wash water will contain only radioactive sodium hydroxide. In this case, the wash water requires only short term storage before the activity level has dropped sufficiently to permit controlled disposal through the plant sewage system. If a fuel rod has ruptured in the reactor core, or in the cleaning cell itself, fission products would be released to the washwater. In this case the wash water would have too high an activity level for disposal without prolonged storage and processing. To detect ruptured fuel rods, the cleaning cell water is sampled and tested for fission products after each element wash. 


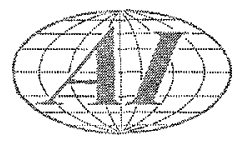

The transfer tanks which accommodate the fuel cleaning, decontamination and maintenance cells, and the sampling equipment for the fuel cleaning wash water are located in shielded areas in the reactor building. The rest of the waste-handling system is housed in a separate building about $400 \mathrm{ft}$ away from the reactor building. All storage tanks, valves, and pumps are located in the vaults which are below grade level and are shielded with reinforced concrete.

The storage capacity of the liquid-waste system is estimated to be sufficient for a 5-yr accumulation of liquid wastes. Sometime during this 5-yr period, if it is deemed necessary, processing and packaging facilities may be added to the system. The processing facilities will consist of distillation equipment and ion exchangers in which radioactivity will be concentrated in smaller volumes, making handling and disposal more economical.

\section{H. ELECTRICAL POWER SUPPLY}

The types of electrical loads are: (1) startup; (2) reactor auxiliary--loads essential to the continuous operation of the reactor; (3) general service--loads required for maintenance, comfort and operations; (4) vital service--loads that can tolerate only a short time outage for protection of equipment and personnel; (5) critical service--loads that require an uninterrupted source of power to protect personnel and equipment.

A simplified block diagram of the power distribution system is shown in Figure 33. Primary power for the electrical loads is 4160 volt, 3-phase, 3-wire, ground wye, $60 \mathrm{cps}$. This primary power is received from the normal station transformer or the reserve station transformer, and serves the reactor dualfeed, selective 4160-volt bus.

The 4160-volt bus feeds the large sodium pumps and 480-volt switchgear $A, B$, and $C$. These load centers feed the larger 480-volt motors, and serve 10 control centers.

Switchgear A and B form a double-ended, secondary selective, unit substation. Secondary selectivity is obtained by a normally open tie-breaker. This unit is arranged with one 4160-480/277 volt, 500-kva transformer section on 


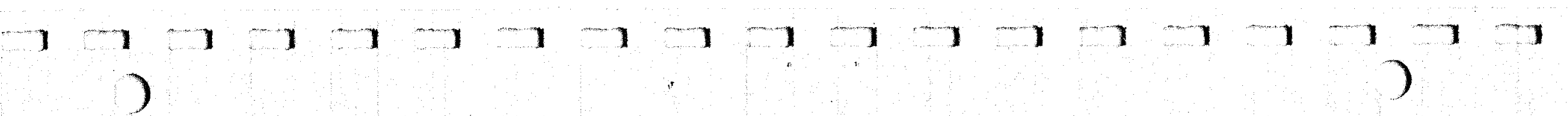

$\infty$
0
$\infty$

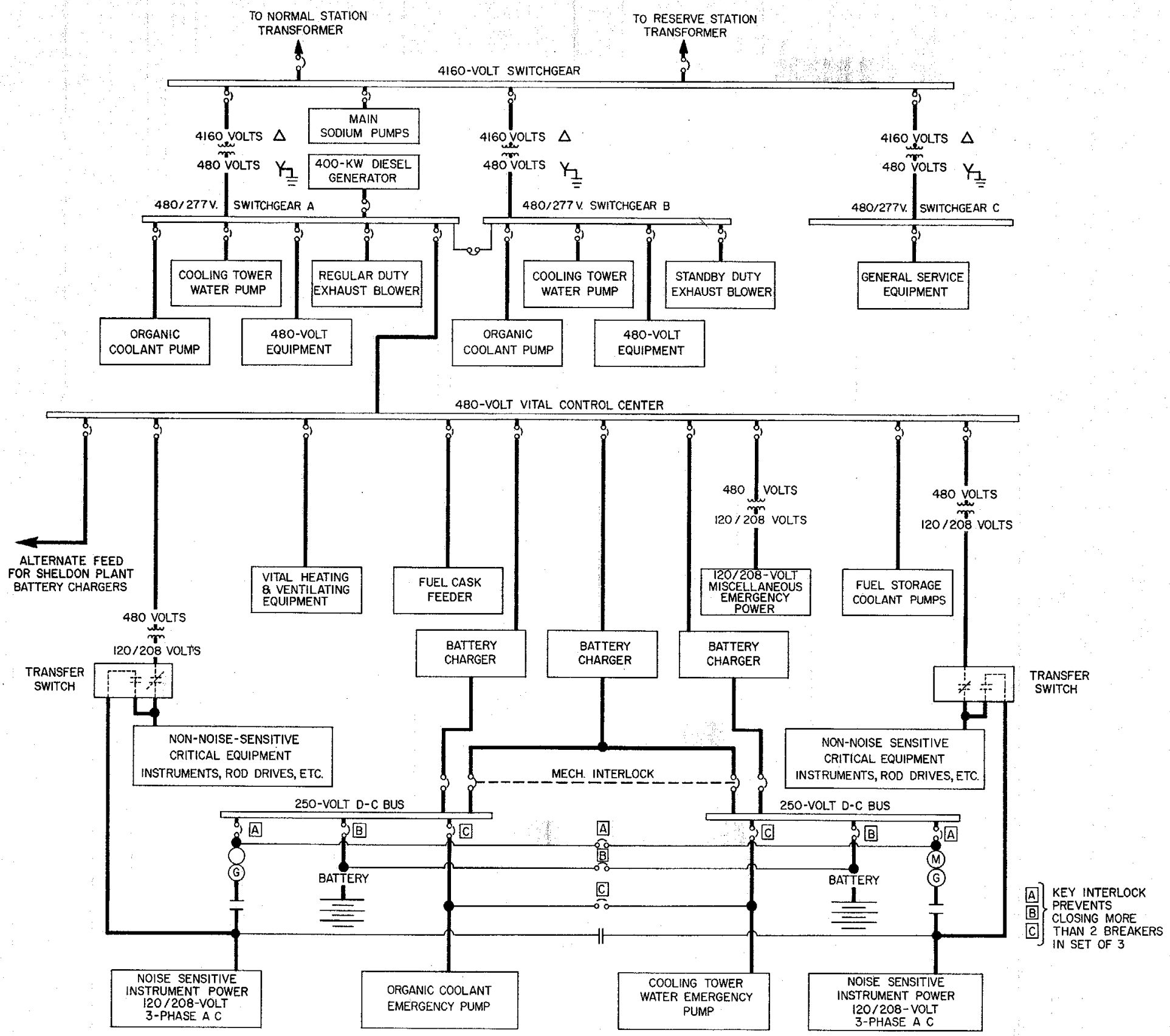

Figure 33. Electrical System 


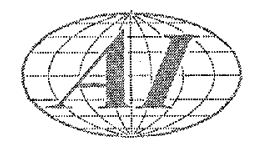

the left end and an identical transformer section on the right end of the switchgear sections. Switchgear A and B supply the power for the 480-volt auxiliary loads and a portion of the startup loads.

Switchgear $\mathrm{C}$ is a single-ended radial distribution unit substation, complete with breakers and a 750-kva, 4160-480/277-volt transformer. This load center supplies the power for the 480-volt general service loads and a portion of the startup loads.

In normal operation, if the reactor is started when the conventional plant is in operation, the reactor will draw 4160-volt power only from the reserve station transformer. Transfer to the normal station transformer will take place after the load of the conventional plant has been reduced. The transfer from one source of power to another at the 4160-volt bus can be made without interruption of power. This is possible because the two sources are synchronized, and can be operated in parallel for a short time.

If there is a loss of primary power, the two incoming line circuit breakers are interlocked so that loss of power from the source feeding the bus will transfer the load to the other source. The transfer time will be short enough so that other breakers and contactors will not open, and the reactor will not scram. Upon restoration of power on the preferred source, the load may be manually transferred back to that source.

Upon the loss of power to load center A, its load would be transferred to load center $B$, and vice versa. Transferring of the load is sufficiently fast so that feeder breakers and contactors on the 480 -volt system remain closed, and a scram does not result.

A loss of both primary sources or loss of both load centers $A$ and B will cause a scram. Power for equipment required during the post-scram period is supplied by the 250-volt, d-c critical buses. Faults that de-energize load centers A and B signal the 480-volt, 3-phase, 60-cycle diesel-generator to start automatically. When the diesel generator is up to speed, and generating rated voltage, the breaker connecting the generator to load center $A$ closes, and the diesel-generator supplies power to one organic coolant pump, one cooling tower water pump, one exhaust blower, and the vital control center. The dieselgenerator is a backup source of power for equipment that can tolerate a short time outage.

VI-22

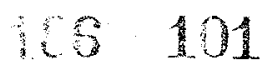





\section{FUEL AND COMPONENT HANDLING FACILITIES}

The fuel and component handling system provides for receipt, handling, storage, and shipment of fuel elements, control rods, moderator and reflector elements, and other replaceable core components required for startup, normal operation, or maintenance of the reactor. Facilities are also provided for handling, decontaminating, and shipping of such replaceable components as pumps and cold traps.

\section{A. SYSTEM AND COMPONENT DESCRIPTION}

The handling system facilities for fuel and core components are as follows:

1) Fuel and moderator handling cask, including a support trolley and a gantry

2) Conversion equipment required for moderator element handling

3) Cleaning cells for fuel elements, other core components, and sodium pumps

4) Storage cells for fuel elements, moderator elements, and other core components

5) Disconnect cell for disconnecting or connecting fuel elements from hanger rods and shield plugs

6) Pickup cell for pickup of new elements by fuel handling cask

7) Shipping casks for fuel elements, other core components, and sodium pumps

1. Fuel and Moderator Handling Cask

The fuel and moderator handling cask consists of a shielded cylinder with a hoist and grapple mechanism to raise and lower components, a gas lock, and indexing devices. The cask is supported and transported by a trolley which in turn rides on a gantry (Figure 34 ).

The cask shielding consists of lead shot confined between the steel walls of the cask body. The greatest shield thickness surrounds the lower section of the cask. Upper section shielding is tapered. A lead-shot-filled skirt provides shielding at the bottom when an element is entering or leaving the cask. 


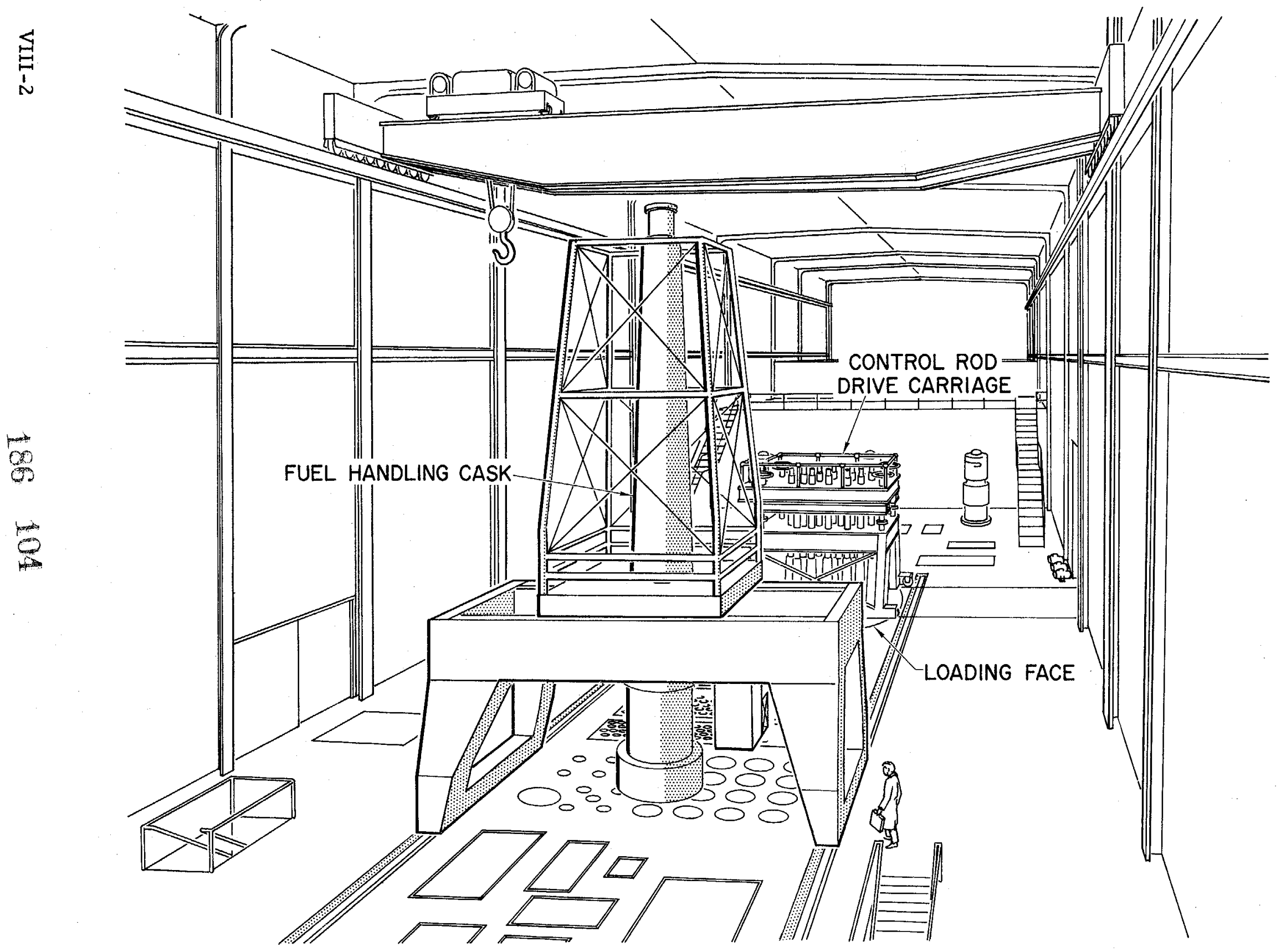

Figure 34. Fuel Handling Cask 


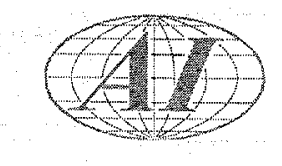

Internally, there are two grapples, each suspended between two continuous roller chains. Each grapple is capable of picking up fuel elements (and similar items) when it is rotated into the pickup position directly above the port in the bottom of the cask. When the cask is travelling, the fuel element is carried in the position 180 degrees away from the pickup position, and the other grapple is kept in the pickup position in the port at the bottom, to seal the cask. As a safety measure, grapples can be released only when they are in the port at the bottom of the cask. Each grapple operates in a guide tube which runs the full height of the cask. The tubes are continuous except for two lengthwise slots. The chains which support the grapples are outside the guide tubes, and a bar between the chains passes through the slots in the guide tube to support the grapple inside the tube.

Two hoists, one for each grapple, are located at the top of the cask. Each hoist mechanism is outside the cask, and the chain sprocket drive shaft passes through a seal in the cask body. A variable-speed electric motor supplies power for the hoist mechanism. The motor is equipped with a brake for quick stopping. Power is transmitted through a slip clutch, gearbox, and torque load cell. A hand crank may be attached on the input side of the gearbox in case of motor failure. A limit-switch assembly with a selsyn and counter is driven from the output side of the gearbox. The limit switches stop the grapple at various predetermined positions. The selsyn and its mate on the control panel are used to drive a counter which indicates the grapple position. The hoist mechanism counter is mechanically driven, and is used to check the operation of the selsyndriven counter on the control panel. A torque-load cell is connected to the slow speed shaft of the gearbox; this cell indicates to the operator what load is on the grapple, and is interlocked to stop the hoist motor if safe loads in either direction are exceeded.

At the bottom of the cask body are television cameras, a gas lock, a helium blower, a photoelectric cell, and a drip pan. As the cask is positioned near a given station, the downward-facing television cameras transmit a picture which shows the operator how accurately the cask is positioned. The gas-lock sleeve is normally carried about 6 in. above the floor. When the cask is positioned, this sleeve can be driven down to make a seal between the cask and the index ring. 
(The index ring was previously positioned and sealed to the reactor face.) A vacuum pump and helium supply are provided to evacuate the gas lock and fill it with helium.

A helium blower nozzle protrudes upward into the cask. After fuel elements have been raised into the cask and rotated 180 degrees from the pickup position, they may be lowered a few inches into the blower nozzle. Helium is drawn from the cask body and is blown upward through the fuel element. A photoelectric cell, at the bottom of the gas-lock sleeve, is interlocked so that neither can the gas lock be evacuated nor can the cask be moved if anything is left attached to the grapple when in the travel position. The drip pan swings in a horizontal plane underneath the raised gas-lock sleeve to catch any debris that may fall.

In the event of a major shutdown due to moderator can failure all the mechanisms from the inside and bottom end of the cask are removed to convert the fuel handling cask for moderator handling. After these are removed, the top half of the cask body may be unbolted and removed. Only the bottom end of the cask body and the movable shield are left in place.

Then the conversion equipment may be added. These are:

a) Cask top plug and grapple assembly

b) Cask shield valve and seal assembly

The cask top plug and grapple assembly consist of a shield plug designed to fit inside the cask body, with a flange on the top for mounting. Of the seven holes which penetrate the plug, six are spaced in the same way as are the fuel channels in the reactor, with the seventh in the center. Solid steel rods which support the moderator can-spreader are located in four of the outer holes. The other two outer holes and the center hole are for the moderator can grapple. Both the spreader and the grapple are raised and lowered by the overhead building crane. Seals are provided for each rod which passes through the cask top plug. Grapple extension rods may be coupled onto the original lengths to permit the grapple to reach down to the lower grid plate of the reactor.

The cask shield valve, bolted to the movable shield of the fuel cask, is basically a large gate valve with lead shielding; and is sealed to the cask body by a sliding seal assembly. 


\section{Cleaning Cells}

Four cleaning cells are provided in which reactor components can be cleaned of sodium and sodium compounds. Each cell consists of a cavity liner and an inner removable thimble. Fuel elements, control rods, and other small-diameter core components are cleaned in the thimble; sodium pumps are cleaned in the liner. The liner also serves as an outer shell for containing the thimble.

Services which are furnished to each cell are dry steam for cleaning, hot demineralized water for rinsing, helium for blanket gas, and vacuum for drying. Steam heating and water cooling can also be applied through coils which surround the small-component thimble. A stainless steel drain line leads from the bottom of the cell to the radioactive liquid waste system.

\section{Storage Cells}

Shielded storage cells are provided for storage of core components as fuel elements, control rods, moderator elements, and so forth. Each smallcomponent storage cell is long enough to accommodate the longest reactor element, and is large enough in diameter for fuel elements and control rods. The sealing surfaces on the upper portion of the cell are identical with the sealing surfaces of the reactor top-shield sleeves. A step, three feet from the top of the cell, also corresponds to a similar step in the reactor sleeve. When the storage cells are not in use, they are plugged at the top. The storage cell plugs are similar to the reactor shield plugs, but are shorter in length.

The moderator storage cells are used to store damaged radioactive moderator cans. The cells are sealed at the top by a steel-plated, concrete shield plug; and maintain a helium atmosphere. Each cell has a machined flange at floor level so that the moderator handling cask and valve may maintain a helium-tight seal with the cell during the removal or insertion of the shield plug or moderator can.

\section{Disconnect Cell}

The disconnect cell houses the equipment for attaching and disconnecting either the fuel element plugs or the storage plugs from the fuel elements. The cell consists of a stainless steel tube into which the fuel element is lowered, and 


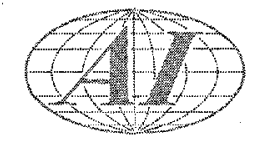

a carbon steel housing for the disconnect machinery. A separate housing for the emergency manual-turning shaft is provided. The plugged outlet of the turning shaft is positioned horizontally to clear the shielding skirt of the fuel element cask. The upper portion of the cell is covered with shielding for radiation protection. Cooling coils are provided for temperature protection of equipment.

The fuel element receiver tube is stainless steel. The rest of the cell is fabricated from carbon steel pipe and plate. Two-inch galvanized lines are provided for vacuum and helium supply.

5. Pickup Cell

The pickup cell is utilized for the transferring of new fuel elements to the fuel handling cask. The cell is not expected to handle radioactive fuel, nor to become contaminated. Helium and vacuum services are required to evacuate the cell in order to transfer the fuel elements to the cask. The top of the pickup cell is machined to the dimensions of the reactor sleeves. The material of the pickup storage tube is galvanized steel. The pipe is schedule-40 galvanized pipe with all joints welded.

\section{Shipping Casks}

Shielded shipping casks are provided in which fuel elements, control rods, and other radioactive components can be transported. The shipping cask consists essentially of lead-shielded steel cylinders, or capcules, in which the components are enclosed for shipping.

The fuel element shipping cask is designed, with respect to both the amount and the location of the fuel in the cask, so that the formation of a critical assembly is impossible. There are no cooling provisions made for the shipping casks, other than normal free convection. Therefore, prior to shipment, fuel elements must be stored until they have cooled off sufficiently so that their temperatures will remain at a safe level while the elements are in the cask.

\section{B. FUEL AND CORE COMPONENT HANDLING}

Two general cycles are involved in the handling of fuel and core components:

1) Refueling of reactor

2) Moderator element replacement

VII- 6 


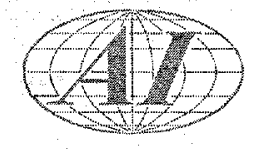

1. Refueling of Reactor - General Description of Cycle

The refueling of the reactor is done in three parts:

a) Loading new fuel into the storage cells

b) Exchanging new fuel for the spent fuel in the reactor

c) Loading irradiated fuel elements into the fuel shipping cask

a. Loading New Fuel into Storage Cell

When a new fuel element is received at the reactor site, it is removed from the shipping crate, inspected, and cleaned. A storage plug is then attached and the plug and element are moved to the pick-up cell. Up to this point the element has been transported by the building crane. From the pick-up cell, the fuelhandling cask takes over and carries the element (with its storage plug) to a storage cell where it remains until it is to be inserted in the reactor.

b. Changing Fuel Elements in Reactor

When refueling is required, the reactor is shut down by inserting the control rods, removing the control rod drives, and reducing the coolant temperatures. The reactor is ready for refueling when the decay heat in the spent-fuel elements to be replaced has reduced sufficiently $(\sim 10 \mathrm{hr})$ to permit handling.

The fuel-handling cask is used to exchange new fuel for spent fuel in the reactor. The new fuel is taken from a storage cell to a disconnect cell where a reactor operating-plug with long hanger rod is attached. The new fuel element is then taken to the reactor, where the new fuel is exchanged for the spent fuel, which is then taken to the cleaning cell for removal of sodium.

The spent-fuel element is washed and dried in the cleaning cell. The fuel-handling cask then returns to take the spent-fuel element to a disconnect cell, where the operating plug is replaced by a storage plug. From the disconnect cell, the spent fuel element is carried to the storage cell by the fuel handling cask.

c. Loading Irradiated Fuel Elements into Shipping Cask

After the spent fuel elements have cooled for a sufficient period of time, approximately 90 days, they may be shipped to the processor. The fuel handling cask is again utilized to transfer the spent fuel elements from the storage cells to the fuel-shipping cask. After the fuel elements are loaded in the shipping cask, the cask is lifted from the pit and placed on a railroad flat car for shipment to the processor. 
2. Refueling Reactor - Component Operation

a. Fuel-Handling Cask

As indicated previously, the fuel elements are moved from station to station (reactor to wash cell, wash cell to disconnect cell, and so forth) by the fuel handling cask. While the cask is in motion, the moving parts of the fuel handling cask are positioned as follows:

1) One grapple is in the port at the bottom end of the cask for sealing and shielding.

2) Gas-lock sleeve is raised to about 6 in. above the floor.

3) Drip pan is in place under the gas-lock sleeve.

4) Movable shield is raised to about 6 in. above the floor.

5) One grapple supports a fuel element in a position 180 degrees away from the port at the bottom end of the cask. The bottom end of the fuel-element process tube is in place in the blower nozzle.

The following basic operations are performed by the cask at a typical station:

1) The cask is brought into the vicinity of the desired station; counters geared to the gantry and trolley wheels show the approximate position of the cask.

2) The cask is positioned over the desired station. Downward-facing television cameras enable the operator to position the cask.

3) The movable shield is lowered to the floor.

4) The drip pan is swung out from under the gas-lock sleeve.

5) The gas-lock sleeve is lowered to seal against the adapter plate (previously installed manually at the desired station).

6) The gas lock is evacuated and filled with helium.

7) The grapple, which was sealing the port at the bottom of the cask, is lowered a few inches to engage the top end of the fuel element to be picked up.

VII -8 


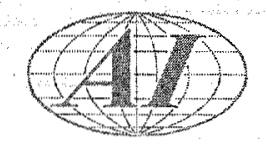

8) The element is raised and positioned in the lower part of the cask. The height of the grapple will depend on the length of plug and hanger rod connected to the fuel element.

9) The fuel element previously in the cask is raised a few inches, so that the lower end of the process tube is lifted out of the blower nozzle.

10) The cask hoist and grapple mechanism are rotated to exchange grapple positions.

11) The fuel element just raised into the cask is lowered a few inches, so that the lower end of the process tube will go into the blower nozzle.

12) The fuel element now over the port in the lower end of the cask is lowered into its hole.

13) The grapple is released when it is in the port at the lower end of the cask.

14) The grapple just released is raised a few inches to seal the bottom of the cask.

15) The gas lock is evacuated and filled with helium. Gas pumped from the gas lock goes to a shielded tank carried on the fuel handling machine. Periodically this accumulated gas is released to the appropriate vent system.

16) The gas-lock sleeve is raised to about 6 in. above the floor. Helium in the sleeve is dispersed in the building.

17) The drip pan is swung into place beneath the gas-lock sleeve.

18) The movable shield is raised to about 6 in. above the floor. The cask is now restored to its original condition and is ready to be moved to a new station. 


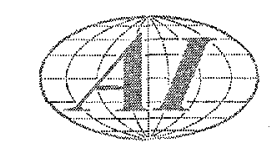

b. Pickup Cell

The operation of a pickup cell is as follows:

1) A new fuel element is placed in the cell, and the cell is evacuated.

2) Helium is bled into the cell, and the cask seal ring is placed on top of the cell.

3) The cask is placed over the cell, and the new fuel element is removed by the cask.

4) A storage plug is placed in the pickup cell by the cask, and the cask and seal ring are removed.

c. Storage Cell

The following steps are performed to store a fuel element.

1) The storage cell plug is removed, and the cells are evacuated.

2) Helium is bled into the storage cell, and the storage cell plug is replaced.

3) The fuel element seal ring is placed on the top flange of the storage cell, and the cask is positioned above the storage cell.

4) The storage plug is removed, and the fuel element is placed in the storage cell by the fuel cask.

5) The cask and seal ring are removed.

The above steps would also apply to the storage of safety rods, control rods, or other small core components.

\section{d. Disconnect Cell}

To disconnect or connect plugs to a fuel element, the following procedure applies:

1) Storage plug is inserted and cell is evacuated.

2) Helium is bled into the cell, and the cask adapter plate is positioned. Normally, the disconnect cell is helium-filled and, to exchange plugs, steps 3 through 7 are followed.

VII- 10 
3) Cask is placed over storage plug, and plug is removed.

4) Fuel element and reactor plug are inserted, and disconnect mechanism disconnects plug from element.

5) With the disconnect grapple holding the fuel element, the reactor plug is removed by the cask and the storage plug is inserted.

6) The disconnect mechanism connects the storage plug to the fuel element.

7) Cask is positioned and withdraws the storage plug and element, and inserts the reactor plug.

The above steps also apply when a reactor plug is to be substituted for a storage plug, except that the plug callout is reversed. Should the disconnectequipment power fail, the operation can be continued by turning the emergency manual-turning shaft.

e. Cleaning Cell

The operating sequence for cleaning a fuel element is as follows:

1) Fuel cask is positioned over cleaning cell, which has been previously purged with helium.

2) Storage plug is removed from cell, and fuel element with reactor plug is inserted.

3) Helium is shut off, and drain valve is opened. Steam is turned on, and fuel element is steam-cleaned for approximately 10 minutes.

4) Steam is shut off, and cell is allowed to drain to radioactive waste system.

5) Hot water valve and vent valve are opened. Cell is filled with hot water from metering tank.

6) Hot water valve is closed, and cell is drained to radioactive waste system.

7) Vent and drain valves are closed, and cell is evacuated and then purged with helium to dry the fuel element. 


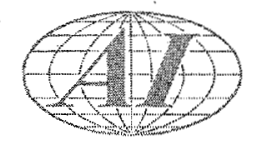

8) Fuel element, with reactor plug, is removed from cell by fuel handling cask, and storage plug is replaced in cell.

Steam heating or water cooling can be applied, as required, through coils which encircle the cleaning cell.

The procedure for cleaning larger components would be similar to that for cleaning fuel elements, except that the fuel wash thimble must be removed from the cell and the cell liner must be used to contain the wash water and cell atmosphere.

\section{Moderator Element Replacement}

When it is desired to replace one or more moderator elements in the reactor core, it is necessary to remove all fuel elements, dummy elements, and so forth, which would interfere with the rotation of the top shield of the reactor. These elements are removed by the fuel handling cask, and the holes in the top shield are filled with storage cell shield plugs. After this is completed, the following operations follow in sequence:

a) The upper shield is rotated and indexed for moderator can removal.

b) The moderator removal plug valve is moved into position over the plug in the upper reactor shield by the building crane. The valve is indexed and sealed to the reactor face.

c) The moderator plug removal cask with its valve attached, is purged and filled with helium and moved by the building crane into position over the moderator removal plug valve.

d) Grapple rods are attached to the moderator removal plug which is then lifted out of the reactor loading face shield into the plug removal cask, and then moved to temporary storage by the building crane.

e) Concurrently, the fuel handling cask has been partially disassembled and modified to handle moderator cans.

f) The moderator handling cask, on its gantry, is indexed manually over the moderator can to be removed. The cask movable shield and shield valve are lowered to rest upon the moderator removal shield valve. The valves are sealed and purged with helium. 



\section{COMPENDIUM - PART TWO}

The foregoing sections (Part I) of this report have presented a description of the Hallam Nuclear Power Facility and an indication of the important safeguards of the facility. The following sections (Part II) present analyses of the potential hazards and controlling safeguards of the facility.

The SGR concept has many inherent safety features. Because the reactor operates at nearly atmospheric pressure and because all materials used in close proximity are chemically compatible, there are no large amounts of releasable potential energy within the reactor which would originate from pressurization or chemical reaction. Therefore, a building of conventional industrial construction can be used to house the reactor.

Within the reactor building, regions of potential radioactive contamination are maintained at slightly less than atmospheric pressure to prevent the outward release of contaminants. The levels of airborn radioactive materials produced during normal reactor operation do not exceed maximum permissible levels, and there is no expectation of a release of such materials which would exceed the allowable amounts.

The reactor and its associated radioactive components are located in concrete shielded cells below the reactor floor level. The shielding reduces normal radiation levels in all working areas to well below normally accepted standards. Confinement of radioactive fluids is provided by welded steel containers and piping, steel liners on the concrete shielding, and sealed joints on the removable shielding. An inert gas atmosphere is used in all areas containing radioactive primary system piping and components, thus preventing any potential hazard from a reaction between radioactive sodium and air.

In the steam generators, double-walled tubes separate the nonradioactive secondary sodium from the steam and water; and an inert monitoring gas passes in annular spaces between the tube walls. The monitoring gas signals the presence of a leak in either tube wall, thus precluding the possibility of a sodiumwater reaction. During tests performed at MSA Research Corporation on a model of this steam generator, actual experience with a tube wall leak (due to manufacturing error) showed that the gas monitoring system operated effectively. 


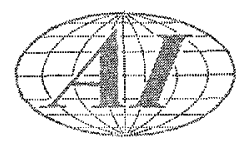

Natural convection flow through any one of the three sodium coolant circuits provides adequate afterglow cooling of the reactor after shutdown. Even with complete loss of external coolant in the primary sodium loops, only a slow rise in reactor temperature after shutdown is ensured by the large heat capacity of the reactor structure. The upper limit of the reactor pressure in this situation is established at a safe level by the heat removal capacity of the auxiliary coolants in the biological shielding.

The automatic plant control system provides for safe normal operation of the reactor power plant. Analog studies of shim-rod withdrawals from several reactor power levels and for loss of forced sodium flow at full power show that the plant protective system provides additional automatic control of the reactor systems for safety against failure or improper operation of any component. The protective system is designed for reliability, with reactor scrams reduced to a minimum by the use of reactor setback (automatic power reduction) before scram conditions are realized. In addition, the high thermal storage capacity of the sodium in the upper plenum prevents thermal transients caused by reactor scrams from causing excessive thermal stresses in the sodium heat transfer system.

The shim-regulating rods, which control reactor power level during normal operation, have a rate-limited motion to ensure that excessive reactivity cannot be inserted by exroneous action. In the event that other protective system action cannot adequately ensure plant safety, gravity fall of the safety rods into the reactor core provides scram action.

The strong negative prompt fuel temperature coefficient of reactivity provides inherent control over increases in reactor power level. In the remote event that the plant protective system should completely fail to function when needed, a nuclear excursion could result under certain abnormal operating conditions. Analysis of nuclear excursions under such restrictive conditions indicates that shutdown of the reactor would be by reactor core meltdown into a subcritical geometry without the release of radioactivity to the surroundings.

The potential hazards discussed in the subsequent sections of the report are presented without regard to their credibility; the final section of the report presents an evaluation of accident credibility, and indicates that accident which is considered to be the maximum credible accident.

VIII-2 


\section{CONFINEMENT OF RADIOACTIVITY}

The requirement of confining fission products and radioactive sodium during all incidents has led to the use of successive enclosures for radioactive materials in the HNPF.

The principal potential hazard associated with the reactor is the possibility of pressurizing the system to the extent that a breach in these enclosures would result. Incidents which postulate the violation of these safeguards are discussed (without regard to credibility) in this section. The activity levels which would result from these (and other) incidents, and the possible subsequent release of radioactivity to the surroundings, are discussed in the next section of the report.

\section{A. SAFEGUARDS FOR CONFINING RADIOACTIVITY}

Fission product activity is present throughout the fuel slugs; these slugs are contained in stainless steel jackets, welded and tested for leak tightness. These stainless steel jackets, located in the primary sodium stream, provide the first enclosure for fission products. Helium spaces located in the upper portion of the jackets provide ample volume for the expansion of the $\mathrm{NaK}$ bond, and for the accumulation of fission gases released from the fuel during irradiation. Rupture of a steel jacket would permit a small fraction of the fission products to enter the primary sodium system where they would be retained by the enclosures for this system.

Primary sodium is confined in an envelope consisting of the reactor vessel, the loading face shield, the reactor vessel bellows, the upper cavity liner, primary piping, pumps, valves, and the intermediate heat exchangers. An outer vessel around the reactor vessel, and guard pipes around the primary pipes (to and including the blocking valve in each loop), provide an additional enclosure within the reactor cavity to prevent uncontrolled loss of primary sodium into the cavity from the reactor, thus ensuring continued coolant flow in the event of a leak.

The loading face shield is made integral with the reactor vessel by the frozen metal (Cerrobend) seal at the top periphery of the loading face shield and upper cavity liner, and the reactor vessel bellows at the top of the reactor vessel. 


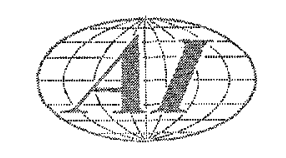

Openings in the loading face shield are lined with steel, and the connections are welded and tested for tightness. Plugs in the loading face shield are sealed to the shield itself with O-ring seals; in addition, hold-down mechanisms with backup seals are provided. The pressure difference across these seals during normal operation is from 0 to $1 / 4 \mathrm{psi}$. The frozen metal seal and the plug seals are classified as maintainable seals, since they can be periodically tested for integrity and any leakage can be stopped.

The reactor cavity, in which the reactor and part of the sodium piping are located, is lined with carbon steel to separate the cavity from the concrete biological shield and foundation. Diaphragm seals isolate the reactor cavity from the piping tunnels (and from the intermediate heat exchanger cells). The biological shield and cavity liner are cooled to a temperature of approximately $150^{\circ} \mathrm{F}$. Since this is below the sodium melting temperature, it presents an effective trap for any sodium vapor that might escape from the reactor vessel. Thus, the reactor cavity liner along with the diaphragm seals provides an additional envelope.

Each primary piping tunnel and intermediate heat exchanger cell is hermetically s.ealed by a welded steel liner which provides a confinement envelope in the event of sodium leakage from the primary coolant system. In the event of a leak in one of these steel liners, a slightly pressurized inert atmosphere (nitrogen), confined within the steel liner, prevents oxygen from entering these regions. The steel liner also prevents moisture in the concrete from entering these areas.

The controlled inert atmosphere within each of the primary pipe tunnels, intermediate heat exchanger cells, and auxiliary primary service cells, is continuously monitored to detect any radioactivity. The nitrogen atmosphere, as well as the helium atmosphere in the reactor cavity, is vented to the radioactive vent system for complete control of any radioactivity which might be present.

The design features outlined above emphasize the precautions taken to prevent the escape of radioactive sodium vapor or fission-product gases into the atmosphere, and to prevent the escape of radioactive liquids or solids into the surrounding subsoil.

IX -2

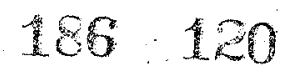


B. POTENTIAL HAZARDS FROM CHEMICAL REACTIONS AND WIGNER ENERGY RELEASE

The proximity of materials which react chemically with each other is intentionally avoided in the design of the sodium graphite reactor. While reactions can occur between some of the materials (uranium-molybdenum, sodium, stainless steel, zircaloy-2, tetralin, and graphite), such reactions would release only insignificant amounts of energy to the reactor core.

Sodium *, $\dagger, \S$ does not react with the materials normally in contact with it in the SGR (stainless steel and zircaloy-2). Any oxygen and hydrogen present in the sodium as impurities would be absorbed by the zircaloy-2; however, the energy released is insignificant. If carbon is present in the sodium it would cause only slight carburization of the stainless steel at $950^{\circ} \mathrm{F}$.

In the event of a moderator can failure, sodium $*, t, * *$ could come in contact with the moderator graphite. If sodium invades porous graphite, it causes an intracrystalline physical expansion of about $2 \%$. In this situation, the formation of chemical compounds such as $\mathrm{Na}{ }_{8} \mathrm{C}$ have been postulated; however, only trace amounts would be formed, since the estimated free energy of formation is $10 \mathrm{k}$-cal/gm-atom-sodium. No significant amounts of energy would be released from this reaction.

The energy stored in graphite decreases with the temperature of irradiation as a result of thermal annealing. In order for an autocatalytic release of this Wigner energy to occur, it is necessary that the incremental energy release per unit temperature excursion be greater than the specific heat. In the operating range of the SGR, the graphite temperature is 600 to $1000^{\circ} \mathrm{F}$, and the energy stored is far too small for an autocatalytic release (see Appendix A). The major effect in this case would be a slight apparent lowering of the specific heat of the graphite.

* S. Siegel et al." "Sodium Graphite Reactor," Proceedings of the International Conference on the Peaceful Uses of Atomic Energy (Geneva, August 1955) (New York: United Nations, 1956), IX, 321

† T. A. Coultas and R. Cygan "Compatibility of Sodium Graphite and Stainless Steel," NAA-SR-258, (July 8, 1953)

$\S \mathrm{R}$. L. McKisson and K. E. Horton, "The Behavior of Tetralin in Liquid Sodium," NAA-SR-1771, (February 1, 1957)

* S. C. Carniglia, "Interactions of Graphite with Liquid Sodium" Proceedings of Frencb-American Conference on Grapbite (reproduced in BNL-489), Session V, Paper C-29. 


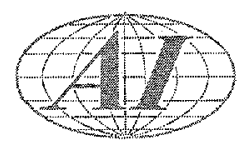

\section{POTENTIAL HAZARDS FROM FUEL ELEMENT FAILURE}

In the event of failure of the fuel rod cladding, sodium coolant would come in contact with the fuel at these points of limited surface area, and would entrain small quantities of fission products in the stream. The noble gases released into the primary sodium system in this manner would be handled by the radioactive vent system; the halogen gases would combine chemically with the sodium and thus be confined within the enclosures for the primary system sodium. Any solid particulate matter would be confined to the primary system. Because of the chemical compatibility between sodium and constituent parts of the rods, there is no possibility of pressure increase in the system due to chemical reaction in this incident.

Each fuel element (Figure 13) is provided with a manually operated variablearea orifice that is used to adjust the coolant flow through the fuel channel. The objective of these orifices is to establish essentially the same temperature of the sodium at the outlet from each fuel channel.

Two thermocouples are located in each fuel channel to measure the sodium temperature. One of these thermocouples is sequentially monitored by the master scanner in the control room. The other thermocouple is available for temperature readings with a portable instrument at the loading face shield while orifice adjustments are being made. Thus, protection is afforded against mis-match of coolant flow and reactor power while the orifices are being adjusted. An extremely large mis-match of flow and power (a flow/power ratio of about $1 / 2$ to 7 ) within any fuel channel could result in meltdown of the fuel element. Melting would occur when the sodium temperature at the fuel channel outlet reaches approximately $1600^{\circ} \mathrm{F}$, causing vapor formation and subsequent flow blockage (see section XIII).

Assuming that the fuel element which has been melted in this manner would release $50 \%$ of the volatile fission products within the element, an activity level of $20,000 \mu \mathrm{c} / \mathrm{cm}^{3}$ due to the noble gases would be experienced in the reactor cover gas; the activity level of the primary sodium would be increased by $10_{\mu}^{4} \mathrm{c} / \mathrm{cm}^{3}$ due to the absorbed halogens (normal sodium activity level is $0.38 \mathrm{c} / \mathrm{gm}$ ). No significant increase of the activity level would be experienced in the reactor operating area. However, considerable residual activity would be retained in the primary system, in addition to the halogens mentioned above. 


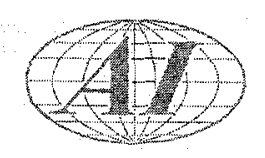

Dilution and retention of the reactor atmosphere gases by the radioactive vent system would effectively control the radioactivity of the noble gases. However, extensive decontamination or maintenance procedures would be necessary in the primary system.

\section{POTENTIAL HAZARDS FROM MODERATOR AND REFLECTOR ELEMENT FAILURES}

Moderator or reflector element cladding failure would result in absorption of sodium coolant by the graphite in the elements, causing localized expansion of the graphite. Since there is no chemical reaction of any significance between sodium and graphite, no appreciable buildup of pressure would result. The undesirable effect resulting from moderator element cladding failure would be the possible development of dimensional interference between the failed element and adjacent core components. Penetration of the graphite by sodium, if extensive in one or two moderator elements, would also cause an increase in neutron absorption properties of the graphite. Calculations show that a $3 \%$ reactivity change (decrease) would result, should complete sodium saturation of the graphite occur in ten centrally located moderator elements.

In the event of excessive pressure under the moderator cans, the holddown device built into each fuel element and into the reflector fillers acts to prevent lifting of the cans above their pedestals.

\section{E. POTENTIAL HAZARD EROM CONTROL ROD THIMBLES}

Thimbles in which the reactor poison control rods travel contain helium at a pressure of about 15 to $25 \mathrm{psig}$. This pressure is sufficient to overcome the hydrostatic pressure which might be imposed if a leak should occur.

If a leak exists in the thimble, and there is a failure of the helium pressurization system, then, if the leak is below the level of the sodium pool, sodium will fill the thimble to slightly above the surface of the pool. If the leak is above the surface of the sodium, then the blanket gas could enter the thimble and eventually reach the gas-tight housing above the loading face shield. This housing would then act as a source of direct radiation to the personnel in the immediate vicinity. Based on the calculations in section $X$, the dose rate one ft from the housing would be less than $10 \mathrm{r} / \mathrm{hr}$. 


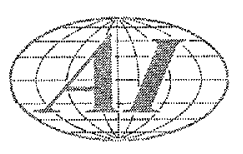

Sodium inside of a thimble could retard the freefall action required by the safety rods, but this would not prevent scram action. As a further protection. against thimble leakage, the thimble helium atmosphere is periodically monitored; in addition, the design of the thimbles provides adequate corrosion and stress allowances to ensure against failure.

\section{F. SAFEGUARDS AGAINST DAMAGE TO CONTROL ROD HOUSING}

The control rod drive mechanisms project above the reactor loading face shield. The controls of the fuel handling gantry and the overhead crane are provided with interlocks which prevent these components from colliding with the control rod drive carriage above the reactor. The fuel handling gantry interlocks are in the form of a limit switch, lock and key bypass, as well as rail blocks which must be physically removed to permit the fuel handling gantry to enter the reactor area. The overhead crane interlocks consist of limit switches and a lock and key bypass system. Allowances are made for stopping dimensions and sufficient load swinging clearance for the crane hook under any probable combination of position, velocity, and load. The principal items of mobile equipment and the possible conditions of conflict are listed in Table XI. For convenience, interlocks involving other items of mobile equipment are also included at this point.

The Type $A$ interlock prevents any approach closer than approximately $3 \mathrm{ft}$ between any part of the fuel handling gantry and the crane, or crane load. This system is a photoelectric relay system. The light sources and photoelectric cells are mounted on retractable outriggers attached to the crane's bridge. The interrupting targets are mounted on outriggers attached to the fuel handling machine. When the light beam is broken, both bridge and trolley motions are stopped on the building crane, and gantry motion is stopped on the fuel handling gantry. Bypass switches are provided to permit passing and can be actuated by keys which can be obtained only from appropriate supervision.

The Type B interlock is a different system, in that one of the conflicting units (the control rod drive carriage) remains stationary over the reactor. A zone interlock system is provided to prevent crane access within a restricted space occupied by the control rod drive carriage. This system includes a series 


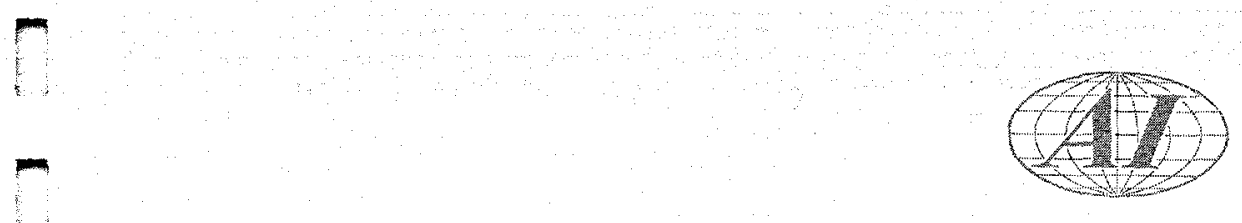

TABLE XI

INTERLOCKS BET WEEN MOBILE EQUIPMENT

\begin{tabular}{|c|c|c|}
\hline Item & $\begin{array}{l}\text { Interlock } \\
\text { Required }\end{array}$ & Remarks \\
\hline $\begin{array}{l}\text { High-bay crane vs fuel handling } \\
\text { gantry }\end{array}$ & yes & Type A \\
\hline $\begin{array}{l}\text { High-bay crane vs control rod } \\
\text { drive carriage }\end{array}$ & yes & Type B \\
\hline $\begin{array}{l}\text { Fuel handling vs control rod } \\
\text { drive carriage }\end{array}$ & yes & $\begin{array}{l}\text { Type } C \text { and reactor startup } \\
\text { interlock }\end{array}$ \\
\hline Fuel handling vs rail car & no & No interference \\
\hline Control rod vs rail car & no & No interference \\
\hline High-bay crane vs rail car & no & Normal use and care \\
\hline $\begin{array}{l}\text { Low-bay crane vs control rod } \\
\text { drive carriage }\end{array}$ & no & $\begin{array}{l}\text { Normal use and care; interfer- } \\
\text { ence possible only when } \\
\text { carriage in maintenance } \\
\text { position }\end{array}$ \\
\hline
\end{tabular}

of four limit switches, the location of which determines the zone of protection. A bypass pushbutton is provided to allow the crane to pass through two semirestricted zones located directly to the east and west of the restricted zone over the reactor. A key-switch bypass is provided to allow the crane to enter the restricted zone with proper supervision.

The Type $C$ interlock is an arrangement of removable rail blocks and a limit switch. The limit switch is mounted on the gantry structure and is wired in the gantry control circuit so as to stop the gantry when actuated by a trigger on the rail. The limit switch is provided with a bypass to permit the fuel handling machine to have access to the loading face when the control rod drive carriage is not over the reactor.

As an additional safeguard against possible physical contact between the fuel handling gantry and the control rod drive carriage, a reactor startup interlock is used to ensure that the rail blocks are in place before the control rods can be withdrawn from the reactor. An audible alarm and annunciator in the control room would signal should the rail blocks be removed at any time. 


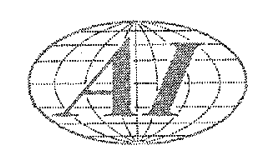

G. POTENTIAL HAZARDS FROM FAILURE WITHIN THE REACTOR STRUCTURE

The reactor structure consists primarily of the reactor vessel, an outer vessel surrounding the reactor vessel, the loading face shield, and the reactor cavity, all of which are described in detail in section IV, par. A-4. To control any potential sodium leakage and prevent uncovering the reactor core, those sections of sodium heat transfer piping which are within the reactor cavity are enclosed in larger diameter guard pipes and the reactor vessel is enclosed within the outer vessel - all of which affords complete secondary liquid confinement. The doublewalled arrangement extends from the reactor through the gallery diaphragm seals to and including the blocking valves in the primary piping tunnels. Helium atmospheres are maintained in all of these volumes. Any sodium leakage in these sections of primary piping would be confined to the annular space between the pipe walls and would drain back to the outer vessel. Leakage into the outer ves sel would be sensed by leak detectors in the vessel and by the continuously monitored sodium level indicators in the reactor vessel, which would detect a drop in sodium liquid level.

The maximum amount of sodium which could leak from the reactor vessel into the outer vessel is limited by the volume of the space between these two vessels. This volume (approximately $1200 \mathrm{ft}^{3}$ ) corresponds to a drop of approximately $4 \mathrm{ft}$ in the elevation of the free surface of sodium in the upper plenum. This is not sufficient to lower the sodium level below the reactor outlet nozzles. Thus, continued flow of sodium coolant through the reactor would not be interrupted, and removal of afterglow heat would be ensured either by free convection or by pump operation. In addition, the sodium in one primary fill tank is maintained at $600^{\circ} \mathrm{F}$ and is continuously available for transfer into the primary system. The capacity of this tank $\left(1950 \mathrm{ft}^{3}\right)$ is sufficient to maintain the sodium level at the operating level.

Should sodium leakage extend through the double-walled piping or the outer vessel, ultimate confinement would be provided by the reactor cavity liner. The cavity volume is sized so that with the addition of the sodium in the standby fill tank, the active core would remain covered with sodium.

The helium atmosphere in the reactor vessel above the free sodium surface is vented and filled through a single 2 -in. diameter line (Figure 35). A 50-psig 


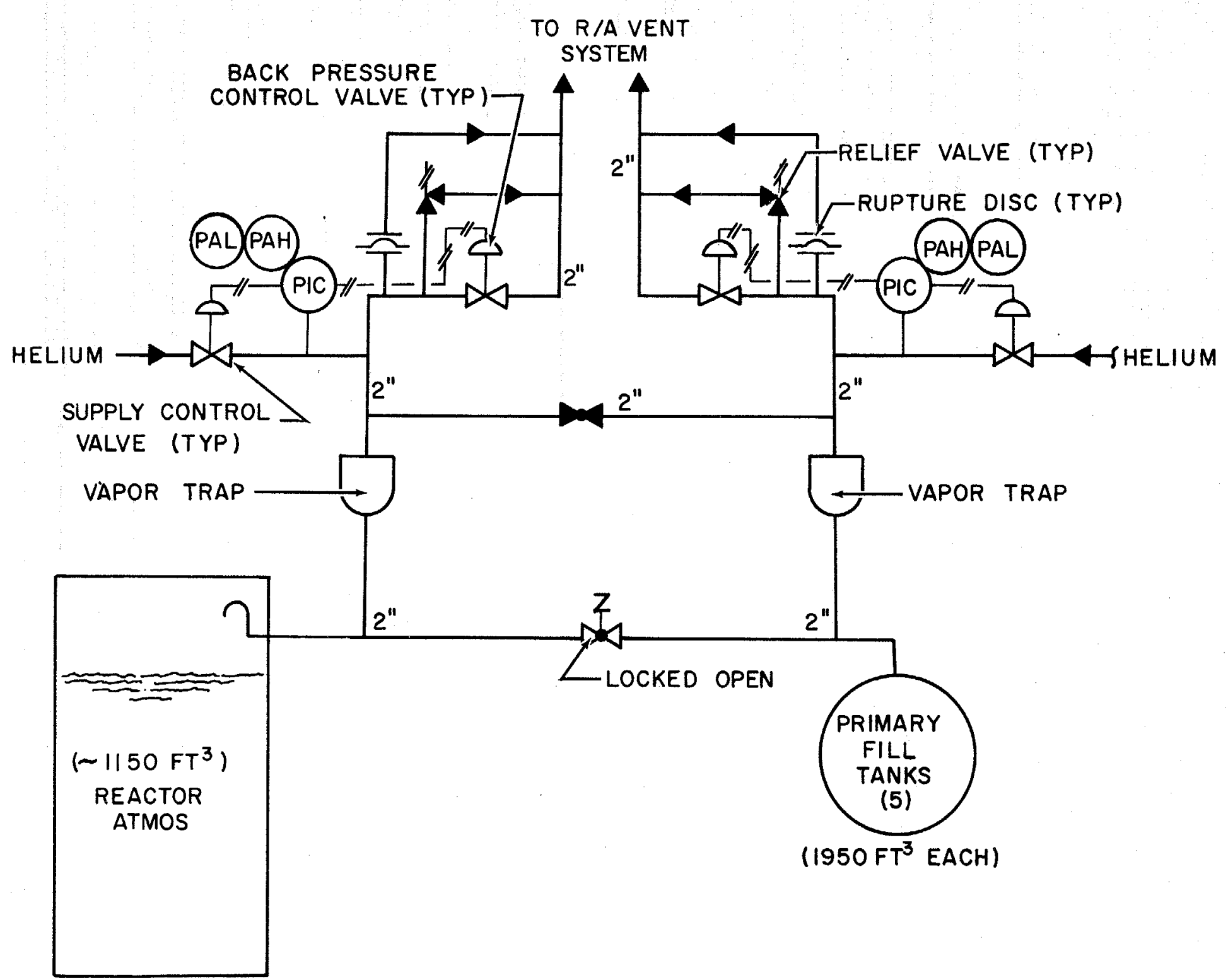

Figure 35. Reactor Helium Atmosphere Supply and Vent System 


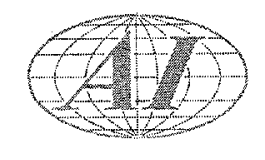

helium supply system is controlled so that the operating pressure of the gas in the reactor vessel varies between 0 and $1 / 4$ psig. This pressure is continuously monitored, with high and low pressure alarms which are provided in the control room. The helium atmosphere is directly connected to the five primary fill tanks with a valve which is locked open.

The reactor and the primary fill tanks are vented through two separate 2 -in. lines to the radioactive vent system. Each of these vent lines has a back pressure control valve, a pressure relief valve and a rupture disc. If the supplyvalve should stick open and the back pressure control valves, reliefvalves, and rupture discs fail to function, the helium service system would pressurize the reactor blanket gas region and the primary fill tanks to a pressure which could not exceed 9 psig (based on the maximum possible capacity of the helium supply being available for gas pressurization). This pressure can be readily contained, since the enclosure for the primary system is capable of withstanding at least 30 psig at operating temperatures.

\section{H. POTENTIAL HAZARDS FROM THE PRIMARY SODIUM SYSTEM}

Since sodium leakage would constitute the main hazard associated with primary system piping failure, special design features to protect against sodium leakage have been incorporated into the piping system. Allowances equal to or better than piping code requirements for corrosion and thermal stresses in piping runs have been used. The sections of sodium heat transfer piping within the reactor cavity are enclosed in larger diameter pipes, as previously discussed. Piping outside the reactor cavity and on the heat exchanger side of the blocking valves is single-walled. Secondary confinement in these areas is achieved by the steel-lined tunnels and heat exchanger cells. A nitrogen atmosphere is provided in these regions and is maintained slightly above atmospheric pressure in order to prevent any in-leakage of air. Sodium leaks in the cells would be detected by leak detectors located on equipment and piping, and also by sodium vapor detectors in the circulating nitrogen cooling system. Should a leak occur in the piping system, protection could be achieved by isolating that loop in which leakage exists, and then draining the loop into the primary fill tanks through the drain connection. 


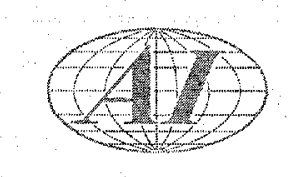

The enclosures for the piping of the primary sodium system are heavily shielded to protect the operating personnel against radiation exposure. The concrete shielding and its internal steel lining provide an effective barrier against direct radiation exposure from the primary sodium systems, as well as ensure the confinement of any radioactivity which may be spilled into these enclosures. The only way in which these enclosures could permit the gross escape of spilled radioactivity would be as a result of excessively pressurizing and releasing the inert gas atmosphere which is confined to the enclosure. Therefore, the possible modes of pressurizing the atmosphere in each of these regions have been investigated and are discussed in the following paragraphs. The maximum permissible gas pressure within these regions has been conservatively calculated to be 6 psig, at which pressure the structural integrity of the cells would remain intact.

\section{Loss of Nitrogen Atmosphere Cooling System}

The nitrogen atmosphere used in each of the enclosures for the primary piping system is continuously cooled by circulating the atmosphere through a gas-to-water heat exchanger. To insure uninterrupted cooling in the event of a component failure, a standby heat exchanger having $100 \%$ cooling capacity is continuously available in each of these regions. This standby cooler can be energized before any significant change would occur in the nitrogen atmosphere.

The water from these gas-to-water heat exchangers is circulated to a water cooling tower which acts as a heat sink for the nitrogen gas. The pumps which circulate the water between the cooling tower and these heat exchangers are connected to the emergency power system (supplied by a diesel-generator set) so that, in the event of a power failure, the pumps would not be out of service for more than a minute. As a backup on the cooling tower, an emergency supply of raw water is also continuously available to these heat exchangers on a oncethrough basis (see Figure 28). Thus, uninterrupted cooling of the nitrogen atmosphere is assured, even if the cooling tower were to be inoperative. A reasonable time for actuating this emergency water system is considered to be $5 \mathrm{~min}$; however, assuming that $15 \mathrm{~min}$ elapse before the actuation were accomplished, the nitrogen temperature in the intermediate heat exchanger cells would rise to about $170^{\circ} \mathrm{F}$, which corresponds to a pressure rise of $1.8 \mathrm{psi}$. The nitrogen temperature in the pipe tunnel for these same conditions would rise to $150^{\circ} \mathrm{F}$, corresponding to a pressure rise of $1.4 \mathrm{psi}$. 


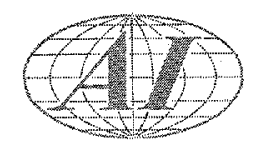

\section{Spill of Sodium}

Considering the sodium contained in the upper plenum of the reactor and in one primary loop, the maximum amount of sodium spillage that could occur due to a rupture in a primary 100 is $160,000 \mathrm{lb}$. Even though it is difficult to postulate a means whereby this amount of sodium could be released in the pipe tunnel or intermediate heat exchanger cells, the consequences of an instantaneous spill of this magnitude have nevertheless been analyzed.

If $160,000 \mathrm{lb}$ of sodium at $945^{\circ} \mathrm{F}$ (normal reactor outlet temperature) are instantaneously spilled from the primary sodium system into an intermediate heat exchanger cell and if the nitrogen cooling system continues at the rated nitrogen flow, the nitrogen temperature in the cell would rise to a mean temperature of $242^{\circ} \mathrm{F}$, which corresponds to a pressure rise of $2.8 \mathrm{psi}$. For the same conditions in the pipe tunnel, the mean nitrogen temperature would rise to $285^{\circ} \mathrm{F}$, corresponding to a pressure rise of $3.85 \mathrm{psi}$.

The pressures and temperatures resulting from these situations are within the 6-psig working limits of the confinement structure for the cells and tunnels.

\section{POTENTIAL HAZARD FROM THE SECONDARY SODIUM SYSTEM}

Since the secondary sodium system contains non radioactive sodium, no radiation hazard is involved, so that the major portion of this system is installed in exposed portions of the plant not protected by inert atmospheres. The secondary system is maintained at a higher operating pressure than the primary system to prevent penetration of the secondary system by the radioactive primary sodium. Radiation monitors would alert operating personnel to the occurrence of any leak before widespread contamination of the secondary system could occur. The reactor would be shut down and the affected primary loops would be immediately drained back to the shielded primary fill tanks.

Each steam generator (and its associated equipment) is enclosed in a separate compartment bounded by $2-h r$ firewalls. Portable chemical hose carts in these compartments provide fire protection against sodium fires of moderate-to-large proportions, and against all possible sodium fires on vertical walls and equipment surfaces. The carts contain a mixture of finely powdered anhydrous metal chlorides and metals (MET-L-X, or equal) propelled through a hose nozzle by dry nitrogen under pressure.

IX -12 


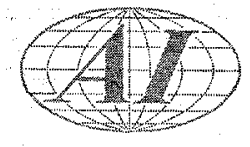

Fire protection against fires which might be caused by small sodium spills on readily accessible horizontal surfaces (and on the floor) is provided by supplies of calcium carbonate stored in metal containers located throughout the areas where such fires could occur. This chemical would be applied by shovel to the affected area to smother the fire.

In addition to normal fire protection provisions, control of a major leak in the secondary system is provided by draining the loop involved into the secondary drain and fill tanks to reduce pressure at the ruptured area.

\section{J. POTENTIAL HAZARD FROM THE SODIUM PUMPS}

Each of the sodium pumps in the primary and secondary systems is equipped with a sodium freeze seal for the pump shaft and for the pump casing. These seals are backed up by mechanical seals which maintain a helium gas atmosphere over the freeze seals. The freeze seals are maintained by cooling coils through which tetralin is circulated.

In the event of a tetralin leak near a freeze seal, thermal decomposition of of the tetralin " coming in contact with the sodium could occur. Tetralin in contact with sodium undergoes rapid decomposition at $675^{\circ} \mathrm{F}$ to form carbon, hydrogen, and low molecular weight hydrocarbons. The hydrogen, and probably the carbon, would be absorbed in the sodium while the hydrocarbons undergo further decomposition to hydrogen and carbon. This reaction would not release significant amounts of energy to the system.

Failure of the shaft or case freeze seals through loss of tetralin cooling would result in sodium entering the pump casing. Sodium in the casing would be detected by temperature indicators located at the freeze seals and bearings. The sodium level inside the casing would then be controlled by the helium atmosphere in the pump casing until the pump is taken out of service. A mechanical gas seal, which retains this helium atmosphere inside the casing, can hold approximately 100 psig (which is in excess of the maximum sodium pressure) without detectable leakage. Leakage due to seal wear is continuously monitored by flow indicators which can serve as a guide to required maintenance.

*R. L. McKisson and H. E. Horton, "The Behavior of Tetralin in Liquid Sodium," NAA-SR-1771, February 1, 1957 


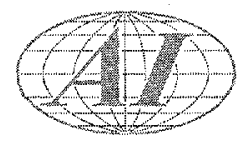

\section{K. POTENTIAL HAZARD FROM THE SODIUM VALVES}

The blocking valves in the primary system, the throttling valves in the primary and secondary system, and the valves in the sodium service system which are directly in contact with the sodium heat transfer system, are each equipped with a sodium freeze seal for the valve stem, and a packed stuffing box which serves as a backup for the freeze seal. The packed stuffing box also provides a seal for the helium blanket which is maintained over the freeze seal. If the freeze seal should be lost due to lack of cooling, the packed stuffing box would permit continued operation of the valve for a period of time sufficient to restore the freeze seal, close the valve, or shut down the valved circuit. When the valves in the primary system are closed, the valve seats are closed against the high pressure side of the valves to minimize the sodium pressure against the seals and stuffing box.

\section{POTENTIAL HAZARD FROM LEAKAGE IN THE INTERMEDIATE HEAT EXCHANGERS}

Possibilities of leakage from any of the intermediate heat exchangers have been minimized by design requirements pertaining to corrosion, thermal stresses, and internal pressure. The design pressure for these units is sufficient to withstand the higher pressure of the secondary sodium system. Sodium leakage from the intermediate heat exchangers would be controlled by the methods previously discussed for the primary sodium system; cell shielding and liner seals would confine any contamination to regions isolated from operating personnel areas.

\section{POTENTIAL HAZARD FROM LEAKAGE IN THE STEAM GENERATORS}

Intermixing of the secondary sodium and water or steam in the boiler or superheater sections could cause generation of excessive pressures and temperatures in these units, which could result in equipment damage. However, because no radioactive sodium is involved in this portion of the heat transfer system, such an accident would not create a radiation hazard.

To protect the system, duplex tubes with an annular space containing helium as a third fluid monitor are used in both the evaporator and superheater. The helium is maintained at a higher pressure than the secondary sodium, but at a lower pressure than the steam. A reduction or increase in the helium pressure 
would give an indication of a break in a tube wall and would permit replacement of the tube bundle prior to development of a serious condition. The integrity of the third-fluid protective system has been demonstrated during tests conducted on a steam generator of similar design operating under conditions similar to those for the HNPF steam generator. A tube weld failure (due to manufacturing error) was experienced during test operations, and the third-fluid alarm system provided detection of the failure; protection of the system against further damage until repairs could be effected was accomplished by the second tube wall.

If a minor leak should occur before the monitoring system indicated a tube wall failure, and a fissure through both tube walls resulted, the sodium-water reaction would form high local temperatures (about $1800^{\circ} \mathrm{F}$ ) but would not cause an overpressurization of the secondary sodium system because the fissure would rapidly fill with sodium-oxide particulate which would stop further leakage. If the oxide particulate did not stop the leakage, there would be some pressure buildup in the secondary sodium system which could be relieved in the secondary expansion tank. The increasing pressure would be a further indication (beyond the monitoring fluid signals) of the leak. In this event, the steam generator involved could be drained of water in order to alleviate the situation until repairs could be made.

\section{N. POTENTIAL HAZARDS FROM THE FUEL HANDLING SYS TEM}

The fuel handling cask is provided with an internal blower which provides forced convection of helium through a fuel element during transfer of the fuel element from the reactor to a fuel wash cell. Loss of electrical power to the cask or a mechanical failure of the blower during fuel element transfer could result in loss of forced convection cooling of the fuel element.

Loss of forced convection cooling would be detected by a gas flow indicator (differential pressure switch) located at the helium blower. In addition, pressure and temperature indicators are used to measure the conditions of the helium gas pressure and temperatures within the cask. The thermal energy removed from the fuel element is transferred to the cask walls which are water cooled.

Detailed procedures for refueling the reactor a re part of the overall development program for the HNPF, and these procedures were not yet fully planned at 


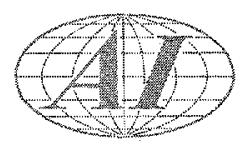

the time this report was in preparation (January 1959). Nevertheless, the normal fuel change operations have been established and are described in section VII. The time elapsed between the initiation of reactor shutdown and fuel element removal could not be less than approximately $10 \mathrm{hr}$. This time element arises from the planned reactor shutdown and the removal of the control rod carriage. Fuel element removal is limited to a rate of approximately one every two hours due to transit times between and time spent at fuel handling stations. Because of the expected radial flux distribution of the group of elements to be removed, it is planned to remove first that element with the least burnup; thus, with the twohours time required for handling each element, the maximum decay heat rate of any element being handled is associated only with the first element removed.

The maximum heat generation rate expected in the cask, with the first fuel element removed from the central region of the core (least burnup), is approximately $0.7 \mathrm{kw} / \mathrm{ft}$. This power output corresponds to the decay heat generation rate for an element removed from the core after 10-hr decay following a power run of one year at 0.8 load factor. Without forced convection cooling of an element having this power output, the fuel cladding and fuel temperatures could rise to about $1660^{\circ} \mathrm{F}$; and the zircaloy tube temperature to about $1200^{\circ} \mathrm{F}$ at the axial position of maximum energy release. Approximately 30 min would be required to reach these temperatures; however, the normal residence time for the fuel element in the fuel cask is about $15 \mathrm{~min}$ between fuel handling stations. Thus, the element would normally be removed before reaching these temperatures.

If that central fuel element which has the maximum decay heat is mistakenly removed at the $10 \mathrm{mr}$ period, the heat generation rate would be $1.2 \mathrm{kw} / \mathrm{ft}$. Without forced convection cooling, the temperatures could be $1830^{\circ} \mathrm{F}$ for the fuel cladding, and $1430^{\circ} \mathrm{F}$ for the zircaloy tube. At these temperature levels, there is a potentiality of fuel cladding rupture by any or all of three mechanisms: (a) an uranium-steel reaction which starts at $1300^{\circ} \mathrm{F}$ and becomes very rapid above $2000^{\circ} \mathrm{F}$; (b) a swelling of the fuel due to the high temperature expansion of the fission product gases; (c) high internal pressures caused by thermal expansion of the NaK and heating of the released fission product gases. 
If the cladding rupture should occur, the $\mathrm{NaK}$ and gaseous fission products would be confined by the fuel handling cask, and a noble gas fission product activity release within the cask of about $2500 \mathrm{c}$ could be expected. This estimate is based upon $1 \%$ of the gaseous fission products being released from the solid fuel into the gas chamber above the NaK bond, and rupture of all nineteen rods. (The chemical affinity between the halogens and sodium effectively retains these isotopes in the $\mathrm{NaK}$ ). Subsequent dilution by the cask atmosphere would produce a maximum activity level of the atmosphere of $700 \mu \mathrm{c} / \mathrm{cm}^{3}$ under these conditions. No pressurization of the cask would be expected, due to the large internal cask volume and the cooling capacity of the water-cooled walls.

The cask is provided with gas seals which minimize gas leakage to a design objective of $1.0 \mathrm{ft}^{3} /$ day (maximum), at 1 psi pressure difference. The normal building ventilation would dilute this leakage in the reactor high bay area to about $6 \times 10^{-6} \mu \mathrm{c} / \mathrm{cm}^{3}$, which is nominally the same as the permissible concentration in air for noble gases, as stated in the Federal Register dated January 29, 1957.

Recovery from this incident can be made by purging the cask atmosphere after connection to the wash cell, removal of the fuel element by cask operation or in the maintenance cell, and by subsequent washing of the fuel handling cask after the ruptured fuel element is removed. 


\section{RADIOLOGICAL CONSIDERATIONS}

Areas of the HNPF which could constitute a radiation hazard to operating personnel are shielded to maintain routing exposures at less than $0.75 \mathrm{mrem} / \mathrm{hr}$ $(1.5 \mathrm{rem} / \mathrm{yr})$. This exposure level is chosen to keep unavoidable "occupancy" exposures well below the $5.0 \mathrm{rem} / \mathrm{yr}$ recommended as a 10 -yr maximum average permissible dose by the International Commission on Radiological Protection (ICRP). The remaining average rate of $3.5 \mathrm{rem} / \mathrm{yr}$ is then sufficient to permit personnel exposures from tasks such as system maintenance and repair, fuel transfer, etc. To reduce the radiation levels in places of routine occupancy, bulk shielding is incorporated in the following source areas:
a) Primary sodium pipe tunnels
b) Intermediate heat exchanger cells
c) Primary sodium fill tank cell
d) Primary cold trap cells
e) Nitrogen compressor cell
f) New fuel cells
g) Spent fuel cells
h) Fuel cleaning cells
i) Maintenance cell
j) Liquid waste storage cell
k) Gas holdup tanks.

During normal operation of the reactor, potential airborne radiation hazards are minimized in the following ways:

a) All systems (sodium, helium, nitrogen, and tetralin) are operated at low pressures, thereby minimizing leakage to adjacent areas.

b) The principle of successive enclosures for the confinement of radioactive materials is utilized throughout.

c) Inert atmospheres are used in the sodium pipe galleries and in the reactor, the reby minimizing any fire hazard and subsequent release of radioactivity. 
d) Pressure differentials between areas of high and low contamination potential are utilized to ensure control of possible leakage.

\section{A. RADIATION LEVELS DURING NORMAL OPERATIONS}

Under normal operation, there is no release of radioactive effluent to the environment in excess of the maximum permissible level as stated in the Code of Federal Regulations. SRE experience has shown that it is practical to limit the normal activity level of the stack releases to no more than the maximum permissible concentration for the mixture of radioactive isotopes in the stack atmosphere. This has been accomplished at the SRE by the same holdup and identification procedure as that planned for the HNPF.

\section{Sources and Associated Activity Levels}

The radiation levels associated with the HNPF reactor can best be examined by summarizing the various sources which contribute to the activities of the system. The sources of radiation which have been examined are the reactor core, the primary sodium system, the tetralin cooling system, the inert gas (helium and nitrogen) systems, and the air in the instrument thimbles. For the purpose of estimating the activity levels associated with these sources, it is assumed that the reactor has operated continuously for a period of 1 yr at a design full power level of $254 \mathrm{Mwt}$. On this basis the maximum activity associated with the fission products in the reactor core is approximately $2.5 \times 10^{9}$ curies.

Based on SIR sodium experiments ${ }^{*}$, where it was found that Cs, Fe, Co, and $\mathrm{Cr}$ accounted for $84 \%$ of the activity due to impurities in the sodium, a value of $7 \times 10^{5}$ has been calculated for the minimum ratio of the equilibrium sodium activity to the activated impurities activity. SRE operating experience to date has indicated a value of $5 \times 10^{6}$ for this ratio. The SIR ratio is therefore chosen as a limiting value. These impurities are corrosion products and impurities initially present in the sodium.

Analysis of tetralin from the SRE system has indicated impurities to be $\mathrm{Mn}, \mathrm{Fe}, \mathrm{Cl}$, and $\mathrm{Cu}$. In order to estimate the activity of the tetralin purchased for the HNPF system, these impurities are each assumed to be present in the

" "Radioactive Accessibility Report," KAPL Memo CTU 1 and 2. 



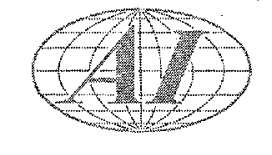

In calculating the argon-41 production from the air activation in the instrument thimbles, it is assumed that convective circulation of the air volume in each thimble would allow complete mixing of all the argon-4l constituent in the thimble volume. The average thermal neutron flux for the bottom foot of a large thimble is $3 \times 10^{9} \mathrm{n} / \mathrm{cm}^{2}-$ sec resulting in an average saturation activity of $8.0 \times 10^{-3} \mu \mathrm{c} / \mathrm{cm}^{3}$ for the thimble atmosphere.

The maximum thermal neutron flux in the primary pipe tunnels is estmated to be only $5 \times 10^{4} \mathrm{n} / \mathrm{cm}^{2}-\mathrm{sec}$; therefore, the production of argon-4l (from air left in the tunnel atmosphere) and carbon-14 (from the nitrogen atmosphere in the tunnel) presents no potential hazard.

Table XIII lists the isotopes produced, the production mechanisms, and the activity concentration at each location where the local atmosphere is exposed to a neutron flux.

\section{TABILE XIII}

\section{ACTIVITY LEVEL OF RADIOACTIVE GASES}

\begin{tabular}{l|c|c|c}
\hline \hline Location & Isotope & Production Reaction & Activity $\left(\mu \mathrm{c} / \mathrm{cm}^{3}\right)$ \\
\hline Core tank atmosphere & $\mathrm{Kr}+\mathrm{Xe}$ & Fission & $6.3 \times 10^{2}$ \\
Instrument thimbles & $\mathrm{A}^{41}$ & $\mathrm{~A}^{40}(\mathrm{n}, \gamma) \mathrm{A}^{41}$ & $8.0 \times 10^{-3}$ \\
Sodium pipe gallery & $\mathrm{A}^{41}$ & $\mathrm{~A}^{40}(\mathrm{n}, y) \mathrm{A}^{41}$ & $4.0 \times 10^{-8}$ \\
atmosphere & $\mathrm{C}^{14}$ & $\mathrm{~N}^{14}(\mathrm{n}, \mathrm{p}) \mathrm{C}^{14}$ & $\sim 10^{-8} / \mathrm{yr}$ \\
\hline
\end{tabular}

\section{Fuel Cleaning Operation}

The cleaning of one 19-rod fuel element normally yields about 50 gallons of radioactive liquid waste. The sources of radioactivity are the activated sodium (which has adhered to the fuel element), fission products present in this sodium as a result of fuel element cladding failure in the reactor, fission products released by cladding failure of rods while in the cleaning cell, and impurities initially present in the sodium and subsequently activated during reactor operation. Each of these sources is examined from the standpoint of its contribution of activity to the radioactive liquid waste system. 


\section{a. Activity From Sodium-24}

Following reactor shutdown from full power operation, fuel elements would not be removed from the reactor for at least 10 hours (section IX-C). After removal from the reactor, the fuel elements are steam cleaned and rinsed in the cleaning cells to remove any adhering sodium. Field tests of the SRE fuel elements indicate that a maximum of $0.22 \mathrm{lb}$ of sodium adheres to a fuel element following sodium immersion; these data lead to an estimate of $0.7 \mathrm{lb}$ of sodium which will adhere to each HNPF element upon removal from the core. If one wash plus one rinse per element are used, then the maximum specific activity of the wash water due to sodium activation will be $4 \times 10^{2} \mu \mathrm{c} / \mathrm{cm}^{3}$. The cleaning cell effluent ( $\mathrm{NaOH})$ is transferred via the radioactive liquid waste system to the decay tanks where it is retained for decay and analysis. Since the half-life of $\mathrm{Na}^{24}$ is $15 \mathrm{hr}$, retention in the decay tanks for 10 days will reduce the specific activity of the wash water to approximately $6 \times 10^{-3} \mu \mathrm{c} / \mathrm{cm}^{3}$.

b. Activity from Fission Products in the Sodium

Fission product activity may be entrained in the primary coolant due to fuel element cladding failure after a long period of reactor operation. Using the same release of volatile fission products as was used in section $\mathrm{X}-\mathrm{A}-1$, and characterizing the decay of the released material as suggested in WASH-740 ("Theoretical Possibilities and Consequences of Major Accidents in Large Nuclear Power Plants"), the fission product activity after a 10-hr decay (section $\mathrm{X}-\mathrm{C})$ will not exceed $8 \times 10^{3} \mu \mathrm{c}$ released to the wash cells from each element washed. Thus, there would be a concentration of $4.3 \times 10^{-2} \mu \mathrm{c} / \mathrm{cm}^{3}$ in the wash water due to fission products (based on the same sodium adherence figures as given above).

\section{c. Activity from Impurities Present in the Sodium}

Based on the SIR experiments cited in section $\mathrm{X}-\mathrm{A}$, the impurities, $\mathrm{Cs}, \mathrm{Fe}, \mathrm{Co}$, and $\mathrm{Cr}$ contribute an activity of approximately $5.3 \times 10^{-1} \mu \mathrm{c} / \mathrm{gm}$ to the primary sodium system. Activity is transferred to the cleaning cell because of these impurities in the sodium adhering to each fuel element. The contribution to the cleaning cell effluent from this is $9.0 \times 10^{-4} \mu \mathrm{c} / \mathrm{cm}^{3}$ of effluent. 


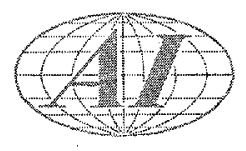

\section{d. Total Activity of Wash Water}

The total activity of the fuel cleaning cell effluent under normal conditions (except fuel cladding failure in the cell) consists of sodium-24 activity, fission product activity, and activity due to activated impurities in the primary sodium system. This results in a total concentration of $4 \times 10^{2} \mu \mathrm{c} / \mathrm{cm}^{3}$ in the cleaning-cell effluent, which is transferred via the radioactive liquid waste system to the holdup tanks for analysis, decay, and subsequent disposal. Since the activity level of this waste solution is primarily due to the $\mathrm{Na}^{24}$ component ( $15 \mathrm{hr}$ half-1ife), holdup for decay significantly reduces the activity. Ten days decay in the holdup tanks will reduce the activity to approximately $6 \times 10^{-3} \mu \mathrm{c} / \mathrm{cm}^{3}$. This specific activity is less than the permissible concentration of $2.4 \times 10^{-2} \mu \mathrm{c} / \mathrm{cm}^{3}$ for $\mathrm{Na}^{24}$ in water, as given in the Code of Federal Regulations. In practice, sampling and isotopic identification are carried out to determine release possibilities; however, long-term-storage capacity is provided for all cleaning liquid waste.

It is reasonable to consider a failure of the fuel rod cladding during the fuel cleaning operations. Assuming that the radioactivity in the fuel element has been permitted to decay for $10 \mathrm{hr}$ prior to beginning the washing cycle, and further assuming that $1 \%$ of the total fission product activity in one fuel rod is released because of the cladding failure, the potential activity released from the fission products is $10^{3} \mathrm{c}$. This activity level would result in a concentration of $5.2 \times 10^{3} \mu \mathrm{c} / \mathrm{cm}^{3}$ in the cleaning water. The long-term-storage capacity for radioactive liquid waste is adequate to handle this situation with no potential hazard.

\section{B. RADIOACTIVE RELEASE TO THE BUILDING ATMOSPHERE}

For the purpose of estimating the hazard of spilling small quantities of radioactive sodium, it can be assumed that small amounts of primary system sodium are spilled and burn. Further, it can be assumed that $50 \%$ of the spill is deposited on the flat surface of the reactor room (due to failout) and that the remaining $50 \%$ is airborne and diffuses evenly throughout the reactor room. Figure 36 relates the total dose rate (as well as the dose rate from fallout and submersion) as a function of the quantity of radioactive sodium spilled (assuming the equilibrium activity of sodium to be $0.38 \mathrm{c} / \mathrm{gm}$ ). The consequences of this type of spill would require extensive decontamination of the high-bay area allowing a reasonable amount of time for decay and ventilation to reduce the radiation 

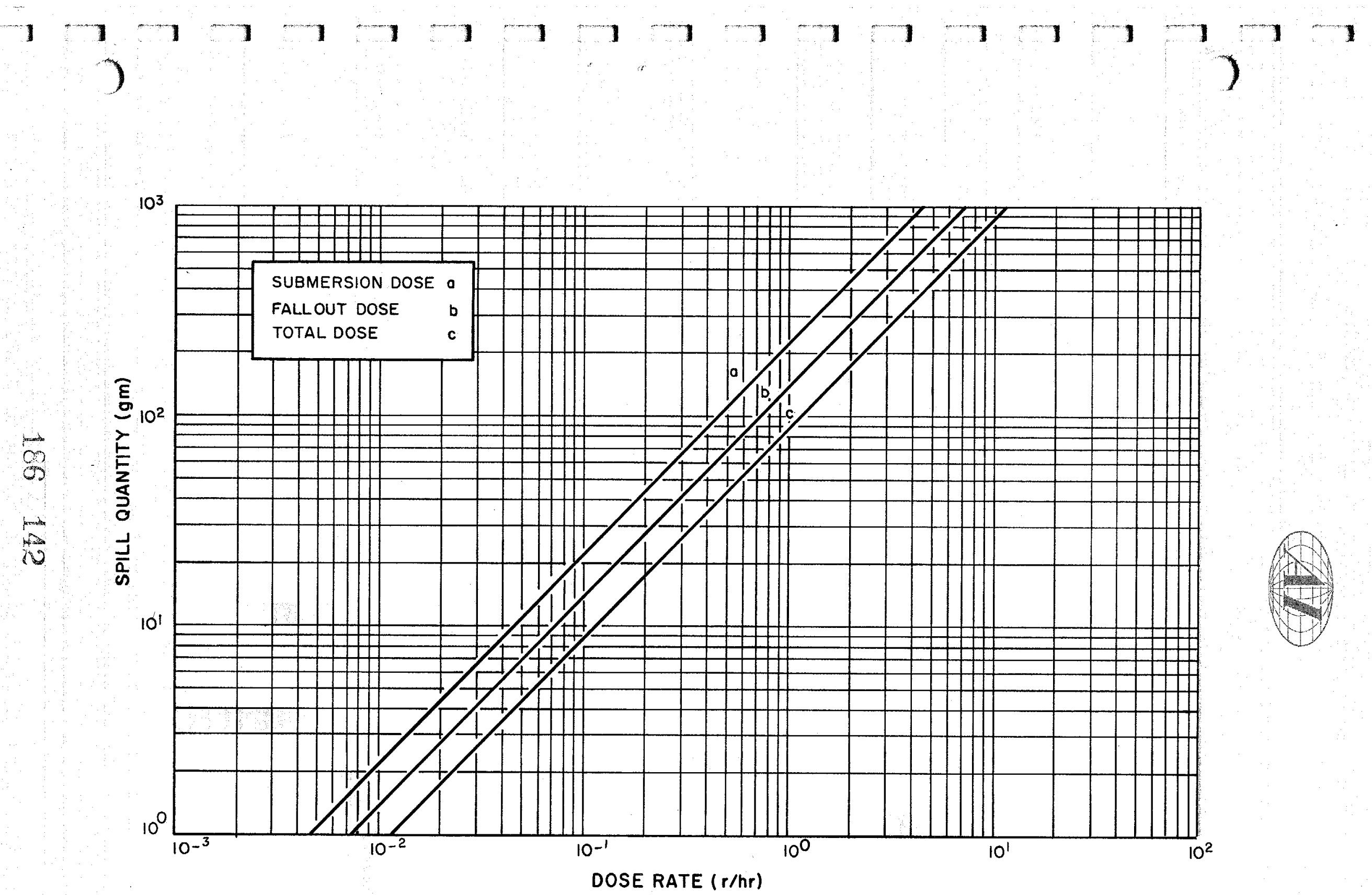

Figure 36. Dose Rate in High-Bay Area Resulting from Radioactive Sodium Spill 


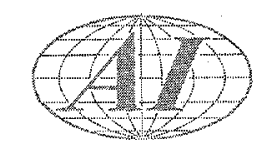

levels. This type of spill would not constitute an environmental hazard since all building effluent passes through absolute filters. These filters are designed for $99.98 \%$ efficiency (DOP Test) for $0.3 \mu$ particles.

The estimated activity as sociated with the tetralin coolant is due to neutron activation of corrosion products and impurities. The activity concentration due to impurities in the tetralin is calculated to be $7.5 \times 10^{-4} \mu \mathrm{c} / \mathrm{cm}^{3}$ (section $\mathrm{X}-\mathrm{A}$ and Table I) after operation of the reactor for $1 \mathrm{yr}$ at full design power (254 Mwt). Spillage of small quantities of tetralin, during maintenance operations on system components, does not represent a radiation hazard.

Under normal conditions the instrument thimble atmosphere is purged to the radioactive vent system, and gas samples are obtained and analyzed before opening and removing any instruments. However, a thimble might be opened and its instrument removed without this preliminary analysis of the situation being made, thereby releasing a portion of the thimble atmosphere to the reactor room. Dilution of the entire thimble contents (see section $\mathrm{X}-\mathrm{A}-1$ ) in a $25 \mathrm{ft}$ by $25 \mathrm{ft}$ by $30 \mathrm{ft}$ space would not result in a concentration which is in excess of the maximum permissible concentration for restricted areas. Release of the entire thimble activity content into the ventilation stack would result in negligible downwind exposures. 


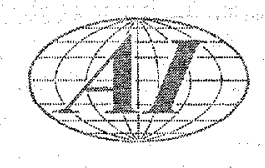

\section{RADIOACTIVE RELEASE FROM THE STACK}

The top of the exhaust stack of the HNPF is $100 \mathrm{ft}$ above grade. The stack is $4 \mathrm{ft}$ in diameter and exhausts air at the rate of about 100,000 scfm. Using Holland's formula for effective stack height and assuming adiabatic flow through the system, the effective stack height has been calculated for various wind speeds as shown in Table XIV. Investigations by O'Gara and Fleming * state that each degree of Fahrenheit of gas temperature above ambient air is equivalent to $2.5 \mathrm{ft}$ of extra stack height. During the winter months, therefore, this serves to increase the effective stack height significantly over that shown in the table.

TABLE XIV

EFFECTIVE ST ACK HEIGHT

\begin{tabular}{c|c}
\hline Wind Speed (mph) & Effective Stack Height (ft) \\
\hline 2 & 370 \\
5 & 208 \\
8 & 167 \\
10 & 154 \\
20 & 127 \\
30 & 118 \\
40 & 114 \\
\hline
\end{tabular}

Downwind activities per unit release rate have been calculated using Sutton's formula for a continuously elevated point source. For the anisotropic case, this equation is:

$$
X_{(x, y)}=\frac{2 Q}{{ }_{\pi} C_{y} C_{z} \bar{u} X^{2-n}} \exp \left[-x^{n-2}\left(\frac{y^{2}}{C_{y}^{2}}+\frac{z^{2}}{C_{z}^{2}}\right)\right]
$$

* P. J. O'Gara and E. P. Fleming, American Smelting and Refining Company, unpublished data as quoted in "Meteorology and Atomic Energy," AECU-3066. 


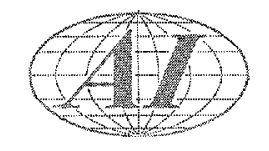

where,

$$
\begin{aligned}
& \bar{u}=\text { wind speed } \\
& X=\text { the ground concentration } \\
& x=\text { the distance downwind } \\
& y=\text { the distance crosswind } \\
& z=\text { the source height (effective stack height) } \\
& Q=\text { the source emission rate } \\
& n=\text { stability parameter } \\
& C_{y}=\text { virtual diffusion coefficient in the crosswind direction } \\
& C_{z}=\text { virtual diffusion coefficient in the vertical direction. }
\end{aligned}
$$

Calculations were made for strong-lapse, neutral, and strong-inversion conditions using the parameters in Table XV. The wind speeds chosen are representative of the associated meteorological condition. Three meteorological conditions were chosen in an attempt to bracket what might be considered as the average conditions at the Hallam site. Conditions such as "looping" or "fumigation" may create downwind concentration greater than the maximum concentration as computed by the Sutton equation; these high concentrations, however, are for brief periods of time $(15 \mathrm{~min})$ and therefore do not significantly add to the total integrated dose.

\section{TABLE XV}

PARAMETERS FOR DOWNWIND ACTIVITY*

\begin{tabular}{l|c|c|c|c|c}
\hline \hline Condition & $\mathrm{n}$ & $\mathrm{C}_{\mathrm{y}}$ & $\mathrm{C}_{\mathrm{z}}$ & $\bar{u}(\mathrm{~m} / \mathrm{sec})$ & $\bar{u}(\mathrm{miles} / \mathrm{hr})$ \\
\hline Strong Lapse & 0.20 & 0.28 & 0.21 & 7 & 15.6 \\
Neutral & 0.25 & 0.21 & 0.12 & 3 & 6.7 \\
$\begin{array}{l}\text { Strong } \\
\text { Inversion }\end{array}$ & 0.50 & 0.10 & 0.06 & 1 & 2.2 \\
\hline
\end{tabular}

*Values for $C_{y}, C_{z}$, and $n$ obtained from "Meteorology and Atomic Energy," AECU-3066. 


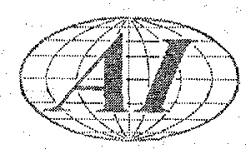

Values of activity concentration $\left[X\left(\mu \mathrm{c} / \mathrm{cm}^{3}\right)\right]$ per unit discharge rate $[Q(c / \mathrm{sec})]$ vs distance are plotted in Figure 37. From these curves, it can be seen that under the various meteorological conditions chosen the distances of maximum concentration occur at 303,782 , and 31,200 meters.

In the absence of wind, radioactive materials discharged from the stack could return to ground level in the immediate area of the reactor and expose operating personnel to a respiratory hazard. Under normal operating conditions activity is released to the stack at a rate calculated to produce no greater than maximum permissible concentrations (MPC) at the stack exit. All activity which could result in greater than MPC at the stack exit is automatically routed to the gas decay tanks where it is held up for decay and subsequent controlled release. Detectors controlling the vent gases are calibrated in terms of the most toxic isotope expected. Release from the decay tanks is made after isotopic identification.

Emergency operations leading to the release of radioactivity could result temporarily in high levels of stack activity concentration. Under adverse conditions, this activity might be introduced into the reactor building by stack downwash. However, downwash on the lee side of an isolated stack does not occur to any appreciable extent if the wind velocity does not exceed the stack draft velocity. Although the HNPF does not have an isolated stack, the stack does have a draft velocity of $90 \mathrm{mph}$; therefore, it is believed that even under emergency conditions of release, no appreciable downwash should occur.

\section{CONSEQUENCES OF A MAJOR HYPOTHETICAL RELEASE OF GASEOUS FISSION PRODUCTS}

The activity associated with the helium atmosphere over the reactor core has been estimated to be $6.8 \times 10^{2} \mu \mathrm{c} / \mathrm{cm}^{3}$ (Table XIII) or a total of $2.0 \times 10^{4} \mathrm{c}$. Because of the low pressure system and the extensive gas and liquid seals in the system, it does not appear reasonable to as sume that more than a very small fraction of this activity could be released to the reactor high-bay area; however, for the purpose of estimating the dose to offsite personnel, two hypothetical releases are considered. 


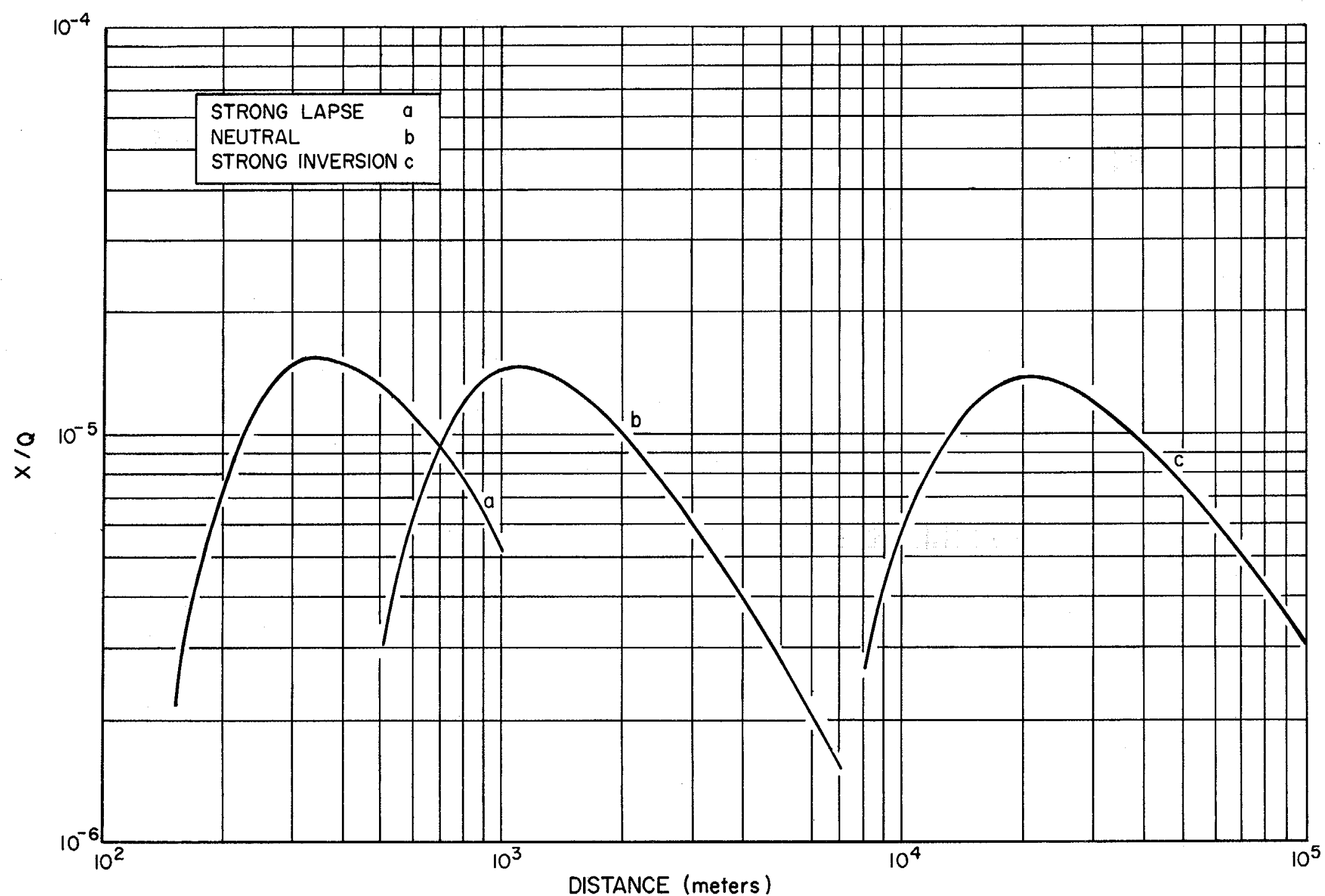

Figure 37. Ground-Level Activity Concentration Downwind of the Facility

Resulting from Release of Radioactivity from Stack (X/Q = activity concentration per unit stack discharge rate) 


\section{(11)}

Case I - Stack Release

1) The total curie content of the He atmosphere $\left(2.0 \times 10^{4} \mathrm{c}\right.$ of $\mathrm{Kr}$ and $\left.\mathrm{Xe}\right)$ leaks instantaneously to the high-bay area.

2) The activity escapes to the environment via the stack at the normal ventilation rate.

3) All particulate activity is removed by the absolute filters.

The total integrated dose has been calculated for the boundary of the closest exclusion area, for the town of Hallam, and for the city of Lincoln. Table XVI summarizes the integrated dose for a stack release where it is assumed that each of the points is directly downwind of the site and is exposed to the full release.

The wind frequencies associated with these locations are: closest exclusion area boundary (E) - 4\%; Hallam (S) - 9\%; Lincoln (NNE) - 5\%; Beatrice (SSE) - 8\%. These wind direction frequencies indicate the low probability of the doses occurring in highly populated areas. The total integrated dose would be much lower if wind directions change during a slow release of activity.

TABLE XVI

DOSE RATE DUE TO MAJOR RELEASE OF GASEOUS FISSION PRODUCTS - STACK RELEASE

\begin{tabular}{c|c|c|c|c}
\hline \multirow{2}{*}{ Location } & $\begin{array}{c}\text { Distance } \\
\text { (miles) }\end{array}$ & \multicolumn{2}{|c}{ Meteorological Conditions } \\
\cline { 3 - 5 } & Neutral $(\mathrm{r})$ & Inversion ( $\mathrm{r}$ ) & Lapse (r) \\
\hline $\begin{array}{c}\text { Closest exclusion } \\
\text { area boundary }\end{array}$ & 0.22 & $7.5 \times 10^{-2}$ & $6.0 \times 10^{-2}$ & $5.0 \times 10^{-2}$ \\
Hallam & 1.50 & $3.0 \times 10^{-2}$ & $5.0 \times 10^{-2}$ & $8.0 \times 10^{-3}$ \\
Lincoln (or Beatrice) & 19.2 & $4.0 \times 10^{-3}$ & $5.0 \times 10^{-2}$ & $<1.0 \times 10^{-3}$ \\
\hline
\end{tabular}

Case II - Ground Release

1) The total curie content of the reactor atmosphere $\left(2.0 \times 10^{4} \mathrm{c}\right)$ leaks instantaneously to the high-bay area.

2) The ventilation system fails and the activity escapes to the environment as a ground-level total release. 


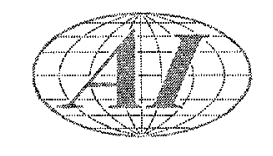

Table XVII summarizes the integrated dose in accord with the conditions stated for Case II.

TABLE XVII

DOSE RATE DUE TO MAJOR RELEASE OF GASEOUS FISSION PRODUCTS - GROUND RELEASE

\begin{tabular}{l|c|c|c|c}
\hline \multirow{2}{*}{\begin{tabular}{c} 
Location \\
\cline { 3 - 5 }
\end{tabular}} & \multirow{2}{*}{$\begin{array}{c}\text { Distance } \\
\text { (miles) }\end{array}$} & Neutral ( $\mathrm{r}$ ) & Inversion (r) & Lapse (r) \\
\cline { 3 - 5 } $\begin{array}{c}\text { Closest exclusion } \\
\text { area boundary }\end{array}$ & 0.22 & $1.4 \times 10^{-1}$ & $6.0 \times 10^{-1}$ & $6.0 \times 10^{-2}$ \\
Hallam & 1.5 & $2.5 \times 10^{-2}$ & $2.4 \times 10^{-1}$ & $4.0 \times 10^{-2}$ \\
Lincoln (or Beatrice) & 19.2 & $1.0 \times 10^{-3}$ & $6.0 \times 10^{-2}$ & $1.0 \times 10^{-3}$ \\
\hline
\end{tabular}

E. CONSEQUENCES OF A MAJOR HYPOTHETICAL RELEASE OF PRIMARY SODIUM

To estimate the consequences of a major incident involving large quantities of primary coolant, two hypothetical releases have been postulated. In each of these cases it is assumed, as above, that each point is directly downwind of the site and is exposed to the full release.

Case I - Stack Release

1) $200 \mathrm{ft}^{3}\left(2.0 \times 10^{6} \mathrm{c}\right)$ of primary coolant at equilibrium activity $(0.38 \mathrm{c} / \mathrm{gm})$ is released from the primary loop and burns.

2) Approximately $25 \%$ remains airborne and is available for discharge via the stack.

3) The absolute filters are bypassed.

The total integrated dose has been calculated las in the case of the gaseous release) for the closest exclusion area boundary, Hallam, and Lincoln. Table XVIII summarizes the data for these points of interest.

* This represents the amount of primary sodium contained in the intermediate heat exchanger and $50 \mathrm{ft}$ of pipe run in one loop of the primary system.

$\dagger \mathrm{J}$. J. Fitzgerald has estimated that from 50 to $90 \%$ of the-activity released from a radioactive sodium fire would be retained in the building due to fallout (KAPL 1527). If the more pessimistic factor is used, first for release from the galleries to the high bay area, and second, for the release from the high bay area to the environment, the result is that no more than $25 \%$ of the initial activity in the galleries actually escapes from the building. 
TAB LE XVIII

DOSE RATE DUE TO MAJOR RELEASE OF

PRIMARY SODIUM - STACK RELEASE

\begin{tabular}{|c|c|c|c|c|}
\hline \multirow[b]{2}{*}{ Location } & \multirow{2}{*}{$\begin{array}{l}\text { Distance } \\
\text { (miles) }\end{array}$} & \multicolumn{3}{|c|}{ Meteorological Conditions } \\
\hline & & Neutral $(r)$ & Inversion $(r)$ & Lapse ( $r)$ \\
\hline $\begin{array}{l}\text { Closest exclusion } \\
\text { area boundary }\end{array}$ & 0.22 & 6.56 & 6.06 & 3.03 \\
\hline Hallam & 1.5 & 3.3 & 5.88 & 0.56 \\
\hline Lincoln (or Beatrice) & 19.2 & 0.04 & 4.71 & 0.008 \\
\hline
\end{tabular}

Case II - Ground Release

1) $200 \mathrm{ft}^{3}\left(2.0 \times 10^{6} \mathrm{c}\right)$ of primary coolant at equilibrium activity $(0.38 \mathrm{c} / \mathrm{gm})$ is released from the primary loop and burns.

2) The building ventilation system is inoperable.

3) Approximately $25 \%$ is available without holdup for release from the building at ground level. (No fallout or rainout from the building is considered.)

Again, the integrated dose has been calculated for the exclusion area boundary, Hallam and Lincoln. Table XIX presents these data for a ground release of primary sodium.

TABLE XIX

DOSE RATE DUE TO MAJOR RELEASE OF PRIMARY SODIUM - GROUND RELEASE

\begin{tabular}{l|c|c|c|c|}
\hline & & \multicolumn{3}{|c|}{ Meteorological Conditions } \\
\cline { 3 - 5 } Location & \multirow{2}{*}{$\begin{array}{c}\text { Distance } \\
\text { (miles) }\end{array}$} & Neutral (r) & Inversion ( $\mathrm{r}$ ) & Lapse (r) \\
\hline $\begin{array}{c}\text { Closest exclusion } \\
\text { area boundary }\end{array}$ & 0.22 & 15.1 & 86.7 & 3.47 \\
Hallam & 1.5 & 3.43 & 47.8 & 0.65 \\
Lincoln (or Beatrice) & 19.2 & 0.05 & 6.9 & 0.12 \\
\hline
\end{tabular}




\section{F. EMERGENCY PROCEDURES}

There is no single plan or evacuation procedure which is suitable for all types of emergencies in a nuclear power plant. There are, however, general rules which would be followed and which are applicable for most situations. A brief outline of these is given below:

1) Emergency doors, road access, etc., are carefully planned to facilitate evacuation of contaminated areas.

2) An automatic alarm system is used to warn all plant personnel if an incident occurs.

3) A complete and specific emergency plan and evacuation procedure will be developed and tested on the site. This plan will include a traffic plan and evacuation area, the use of protective clothing and methods of decontaminating personnel, and designation of authority in the event that an emergency arises.

4) A program for complete environmental monitoring will be designed to start immediately after an incident occurs.

5) Community leaders and organizations will be integrated into emergency plans.

6) A public relations program will be set up whereby accurate information concerning any incidents will be made available to the public. 


\section{REACTOR KINETICS}

\section{A. NUCLEAR AND KINETICS PARAMETERS}

There are many nuclear and kinetics parameters of the reactor core which can have an important influence on the safety characteristics of the plant. Such things as excess reactivity, control rod reactivity, power coefficient, temperature coefficients, neutron lifetime, and effective delayed neutron fraction all have a strong influence on the type of operating transients which can be experienced. Each of these important parameters is discussed in the following paragraphs.

\section{Excess Reactivity}

The maximum excess reactivity loaded initially into the HNPF reactor is dictated by the maximum operating life required of the initial core loading. This initial loading probably requires less excess reactivity than subsequent fuel cycles, although the details of these fuel cycles have not been worked out. A tabulation of the excess reactivity required for the initial core loading is shown in Table XX.

\section{TABLE XX}

\section{EXCESS REACTIVITY REQUIREMENTS}

\begin{tabular}{|lc}
\hline Xenon and Sama rium (Equilibrium) & $2.5 \%$ \\
Fuel Depletion and Long-Term & $2.5 \%$ \\
Fission Product Buildup & $0.5 \%$ \\
Control Margin & $5.5 \%$ (at design power) \\
Total Excess Reactivity &
\end{tabular}

This excess reactivity is evaluated for the situation with the reactor at rated power and temperature, and with no poison buildup yet present. Because of the effect of the Doppler temperature coefficient on reactivity in the metal fuel elements, the excess reactivity is strongly a function of the temperature of the fuel elements. The most reactive condition occurs when the reactor power level is quickly reduced from rated conditions. The fuel element temperature decreases rapidly, but the graphite temperature, because of its large 
thermal storage capacity, does not. Because of the positive graphite temperature coefficient and the negative fuel temperature coefficient, reactivity within the core can be increased by a maximum of $0.8 \%$. Thus, the total excess reactivity contained in the unpoisoned reactor is $6.3 \%$ at the most reactive condition.

2. Control Rod Reactivity

The total reactivity contained in the control rods is adequate to shut down the reactor with a reasonable margin when the core is in the most reactive condition. The core reactivity can be reduced by either the safety rods or the shim regulating rods. Either set of rods is capable of rendering the core subcritical in its most reactive condition. The total reactivity worth of both the safety rods and the shim regulating rods is shown in Table XXI.

TABLE XXI

REACTIVITY WORTH OF RODS

\begin{tabular}{|c|c|}
\hline & Excess Reactivity Worth \\
\hline \multicolumn{2}{|l|}{ Safety Rods } \\
\hline Total worth of 15 rods & $9 \%$ \\
\hline $\begin{array}{l}\text { Shutdown margin with only safety } \\
\text { rods inserted and core in most } \\
\text { reactive condition }\end{array}$ & $9 \%$ minus $6.3 \%=2.7 \%$ \\
\hline \multicolumn{2}{|l|}{ Shim-Regulating Rods } \\
\hline Total worth of 13 rods & $8 \%$ \\
\hline $\begin{array}{l}\text { Shutdown margin with only shim } \\
\text { regulating rods inserted and core } \\
\text { in most reactive condition }\end{array}$ & $8 \%$ minus $6.3 \%=1.7 \%$ \\
\hline \multicolumn{2}{|l|}{ All Rods } \\
\hline Total worth of 28 control rods & $\begin{array}{c}17 \% \text { (neglecting shadowing } \\
\text { effects) }\end{array}$ \\
\hline $\begin{array}{l}\text { Shutdown margin with all control } \\
\text { rods inserted and core in most } \\
\text { reactive condition }\end{array}$ & $17 \%$ minus $6.3 \%=10.7 \%$ \\
\hline
\end{tabular}


The maximum controlled rate at which reactivity can be removed or inserted into the core by the rod drive motors is limited absolutely by the use of induction motors on all rod drive mechanisms. This peak reactivity rate is limited to $0.03 \% / \mathrm{sec}$ when all shim-regulating rods (or safety rods) are operated simultaneously in their peak-reactivity-worth region. Because of the essentially constant-speed motors, the reactivity rate is always less when the rods are operated at positions other than their peak worth region.

3. Power Coefficient of Reactivity

The steady state (or static) power coefficient is an important parameter in the determination of the inherent stability of the reactor. This parameter is defined by the following,

$$
H_{s s} \equiv \frac{\Delta \rho}{\Delta p}
$$

where:

$$
\begin{aligned}
H_{s s} & =\text { steady state power coefficient } \\
\Delta p & =\text { change in reactor power } \\
\Delta p & =\text { resulting net change in reactivity after all transients have subsided }
\end{aligned}
$$

The net change in reactivity $(\Delta \rho)$ is due to the temperature changes of the various components of the core, and the resultant effect of the new temperature on the neutron cross sections. Since the power coefficient is defined for the steady state condition, it can give no indication of the dynamic behavior of the reactor other than to indicate whether a steady state can ultimately be reached after a change in reactivity is made and no external compensation is provided. This steady state power coefficient is therefore a measure of the static stability of the reactor.

The steady state power coefficient is evaluated by considering the important reactivity effects of temperature changes of the individual reactor components and the resultant temperature change of each component with power level. The three important individual temperature effects on reactivity in the core are 


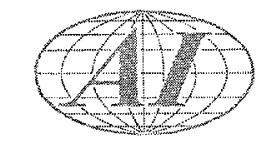

those in the fuel, coolant, and graphite. The total change in reactivity for a change in power level can be approximated closely by summing the individual effects as

$$
H_{s s}=\frac{\Delta \rho}{\Delta p} \cong \alpha_{F}\left(\frac{\Delta T_{F}}{\Delta p}\right)+\alpha_{G}\left(\frac{\Delta T_{G}}{\Delta p}\right)+\alpha_{N}\left(\frac{\Delta T_{N}}{\Delta p}\right)
$$

where

$$
\begin{aligned}
\Delta T_{F} & =\text { change in average fuel temperature } \\
\Delta T_{N} & =\text { change in average sodium temperature } \\
\Delta T_{G} & =\text { change in average graphite temperature } \\
a_{F} & =\text { fuel temperature coefficient of reactivity } \\
\alpha_{N} & =\text { sodium temperature coefficient of reactivity } \\
a_{G} & =\text { graphite temperature coefficient of reactivity }
\end{aligned}
$$

The terms in the parentheses can be considered as the suitably averaged temperature change of a particular component for a unit change in reactor power. They are rather complex functions of the heat transfer parameters for the system, and include such factors as sodium flow rate, thermal conductivity, heat transfer coefficients, surface areas, and heat generation densities. By using the best available values of the reactor parameters, it is found that the power coefficient is negative for all power levels when the reactor has no burnup. As the reactor burnup progresses, the power coefficient becomes positive. This change is due to the effect of irradiation on lowering the thermal conductivity of the graphite (see Appendix A). The change in conductivity is dependent on the amount of irradiation and the temperature of irradiation; however, the rate of change becomes small with long irradiations. A decrease in thermal conductivity will result in higher graphite operating temperatures. This causes the positive reactivity component due to the graphite to be a larger effect. In fact, it can cause the overall steady state power coefficient to become positive. Power coefficients for the irradiated case were calculated on the basis of assuming a graphite thermal conductivity of 
$15 \mathrm{Btu} / \mathrm{hr} / \mathrm{ft} /{ }^{\circ} \mathrm{F} .^{*}$ This value is representative of the graphite conductivity after an irradiation of $10^{21} \mathrm{nvt}$.

Equation 1 expresses the power coefficient as a function of sodium flow when the reactor graphite is unirradiated.

$$
H_{s s}=\frac{\Delta \rho}{\Delta p}=-10^{-5}\left(0.6+\frac{0.17}{x}\right) \frac{\Delta k / k}{M w}
$$

where

$$
x=\text { fraction of rated flow }
$$

Equation 2 is for the power coefficient when the reactor has aged sufficiently to reduce the thermal conductivity of graphite to its minimum value.

$$
H_{s s}=\frac{\Delta \rho}{\Delta p}=+10^{-5}\left(2.87-\frac{0.17}{x}\right) \frac{\Delta k / k}{M w}
$$

The steady state power coefficient for both irradiated and unirradiated graphite is shown plotted in Figure 38 . It is seen then that the power coefficient is positive for irradiated graphite, except at very low flow rates (less than $3 \%$ ). Fortunately however, the positive component of the power coefficient is very slow acting and therefore results in only a slow drift upward in reactor power for step increase in reactivity. The following sequence of events illustrates this behavior.

a) A small positive step of reactivity is inserted by the control rods.

b) The reactor power rises immediately due to the reactivity insertion.

c) Because of the rapid response of the fuel temperature, the initial insertion of reactivity will be compensated for by the negative Doppler reactivity coefficient. The positive reactivity produced due to the sodium temperature change is small in comparison to the fuel's negative effect. The net result is a prompt negative

* Personal communication, National Carbon Co., Cleveland, Ohio. 

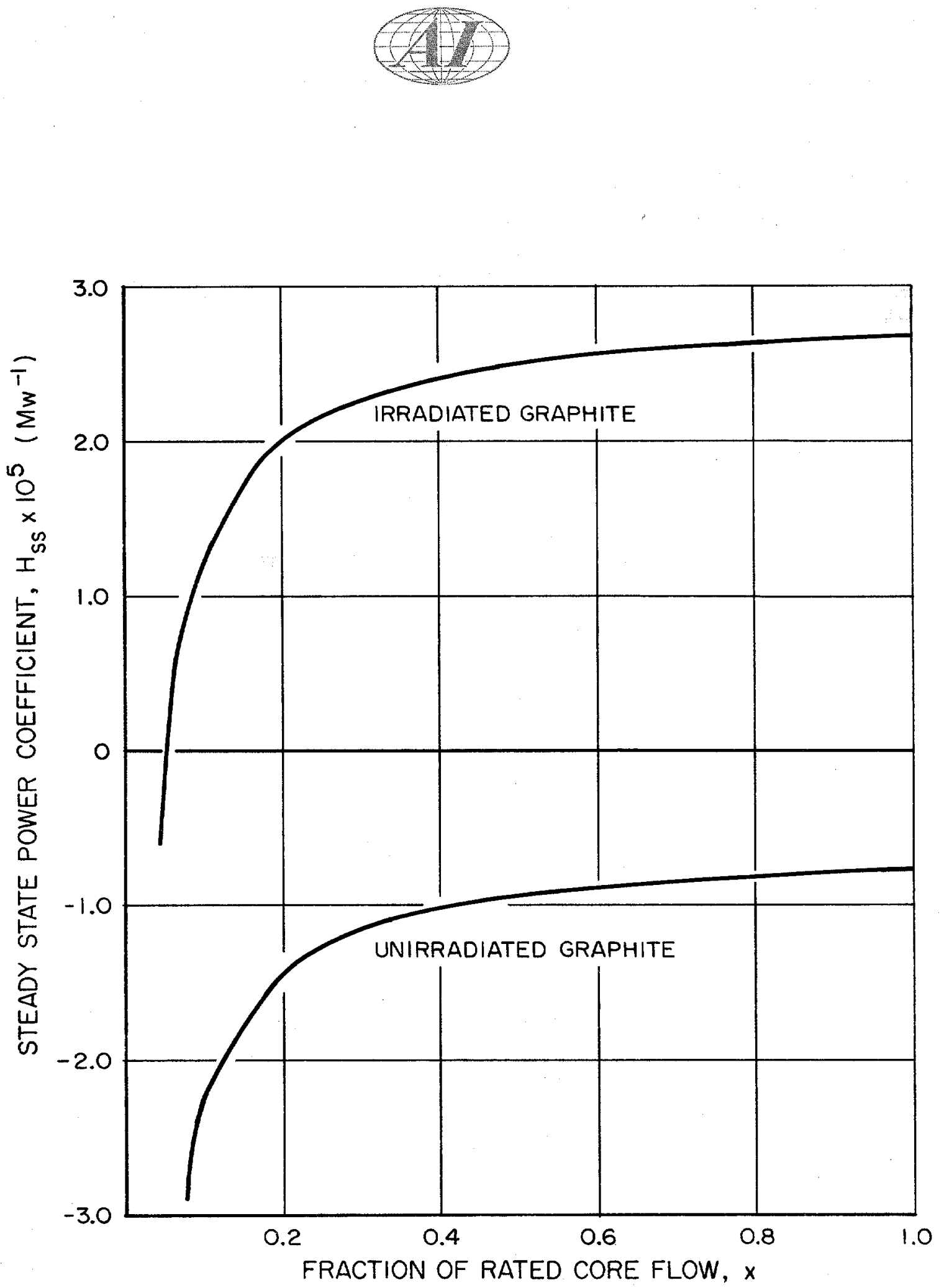

Figure 38. Steady State Power Coefficient as a Function of Fraction of Rated Core Sodium Flow Rate 


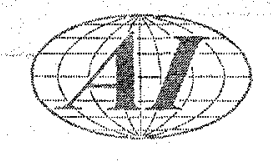

power coefficient which effectively curbs the rise in power and causes the reactor to reach a quasi-steady state condition.

d) The quasi-steady state condition is only apparent since the slow rise in temperature of the graphite produces additional positive reactivity. This additional reactivity cannot be completely nullified by the fuel as displaced by the positive overall power coeffi cient. The resultant power rise occurs so slowly that it would only be noticed minutes after the reactor has reached its apparent steady state. Further illustration of this behavior is given in the section on the long-term dynamics (section XI-B-1) of the reactor. This behavior can be classified as a static instability and its effect on reactor safety is inconsequential.

4. Temperature Effects on Reactivity

In order to determine the steady state power coefficient of reactivity dis cussed above, it is necessary to calculate the important individual temperature effects within the reactor which affect the total reactivity. These effects are:

a) Changes in temperature within the metal fuel and their resulting effect on resonance absorption through the Doppler effect.

b) Changes in sodium temperature and the resulting change in sodium density, and hence, total neutron absorption changes.

c) Changes in graphite moderator temperature and the resulting changes in the equilibrium neutron energy distribution. This change in the effective neutron temperature causes a change in microscopic cross sections and results in changes in flux distribution within the unit cell.

The total reactivity effect due to changes in these individual temperatures can be approximated by a sum of the three individual effects, providing these changes in temperatures are kept sufficiently small:

$$
\Delta \rho_{T} \cong \alpha_{F} \Delta T_{F}+\alpha_{N} \Delta T_{N}+\alpha_{G} \Delta T_{G}
$$




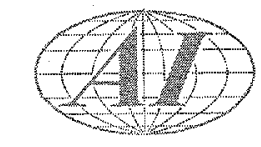

These individual effects on reactivity for the HNPF reactor core operating at temperature conditions corresponding to full reactor power are:

$$
\begin{aligned}
& a_{F}=-3.05 \times 10^{-5} /{ }^{\circ} \mathrm{F} \text { (fuel temperature coefficient) } \\
& a_{N}=+0.5 \times 10^{-5} /{ }^{\circ} \mathrm{F} \text { (sodium temperature coefficient) } \\
& a_{G}=+2.2 \times 10^{-5} /{ }^{\circ} \mathrm{F} \text { (graphite temperature coefficient) }
\end{aligned}
$$

The is othermal temperature coefficient of reactivity is defined as the reactivity change per unit change in core temperature, providing all components of the core(i.e., fuel, sodium and graphite) change by the same amount. That is,

$$
\Delta T_{F}=\Delta T_{N}=\Delta T_{G}=\Delta T_{i s o}
$$

Since the value of the isothermal temperature coefficient is useful in estimating the reactivity changes to be expected when the plant is being initially heated, it can be approximated by adding the individual temperature coefficients, which gives

$$
\frac{\Delta \rho}{\Delta T_{\text {iso }}}=a_{\text {iso }} \simeq a_{F}+a_{N}+\alpha_{G} .
$$

where

$$
\begin{aligned}
a_{i s o} & =\text { isothermal temperature coefficient of reactivity } \\
\alpha_{N}^{\prime}, \alpha_{F}, \text { and } \alpha_{G} & \text { are as defined previously, } \\
\Delta T_{i s o} & =\text { isothermal change of the reactor core temperature. }
\end{aligned}
$$

Using the values of the individual temperature coefficients given above, the isothermal coefficient is found to be

$$
a_{i s o}=-0.35 \times 10^{-5} / \circ \mathrm{F} \text {. }
$$

\section{Other Kinetics Characteristics}

In addition to the power and temperature coefficients of reactivity, the values of the parameters which are used in the reactor kinetics equations are 


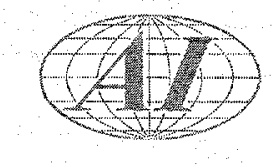

important in the core transient studies. Values used in these studies are as follows:

$$
\begin{aligned}
& l=\text { neutron lifetime }=3.3 \times 10^{-4} \mathrm{sec} \\
& \bar{\beta}=\text { effective delayed neutron fraction }=0.0069
\end{aligned}
$$

In Figure 39 reactor stable period is shown as a function of excess reactivity (Inhour plot).

The response of the reactor (without temperature effects) to a sinusoidal reactivity oscillation is useful in the core stability analysis. The zero power transfer function as a function of frequency is shown in Figure 40 .

\section{B. REACTOR CORE DYNAMICS}

The core dynamic behavior can be conveniently separated into two parts - - -1ong term and short term. This is made possible because of the distinct differences in the time behavior of the temperature changes of the major components of the core during power transients. The large heat-storage capacity and low heattransfer coefficients of the canned graphite moderator make its temperature response to power variations very sluggish. The metal fuel and sodium coolant temperatures, on the other hand, respond rapidly to power changes. A fairly good estimate of the relative time behavior can be obtained by determining the time constants of the components. These time constants are as follows:

$$
\begin{aligned}
\tau_{F} & =1.6 \mathrm{sec} \\
\tau_{N} & =0.65 \mathrm{sec} \\
\tau_{G} & =20 \mathrm{~min} \text { (unirradiated) } \\
\tau_{G} & =48 \mathrm{~min} \text { (irradiated to } 10^{21} \mathrm{nvt} \text { ) }
\end{aligned}
$$

1. Long Term Dynamics

The following equation has been derived to approximate the transient response of the reactor due to a step change in reactivity.

$$
p=p_{0}-\frac{\rho_{e x t}}{H_{s s}^{\prime \prime}}+\frac{\rho_{e x t} H_{s s}^{\prime}}{H_{s s} H_{s s}^{\prime \prime}}\left[1-\exp \left(-\frac{H_{s s}}{H_{s s}^{\prime \prime} \tau_{G}} t\right)\right]
$$




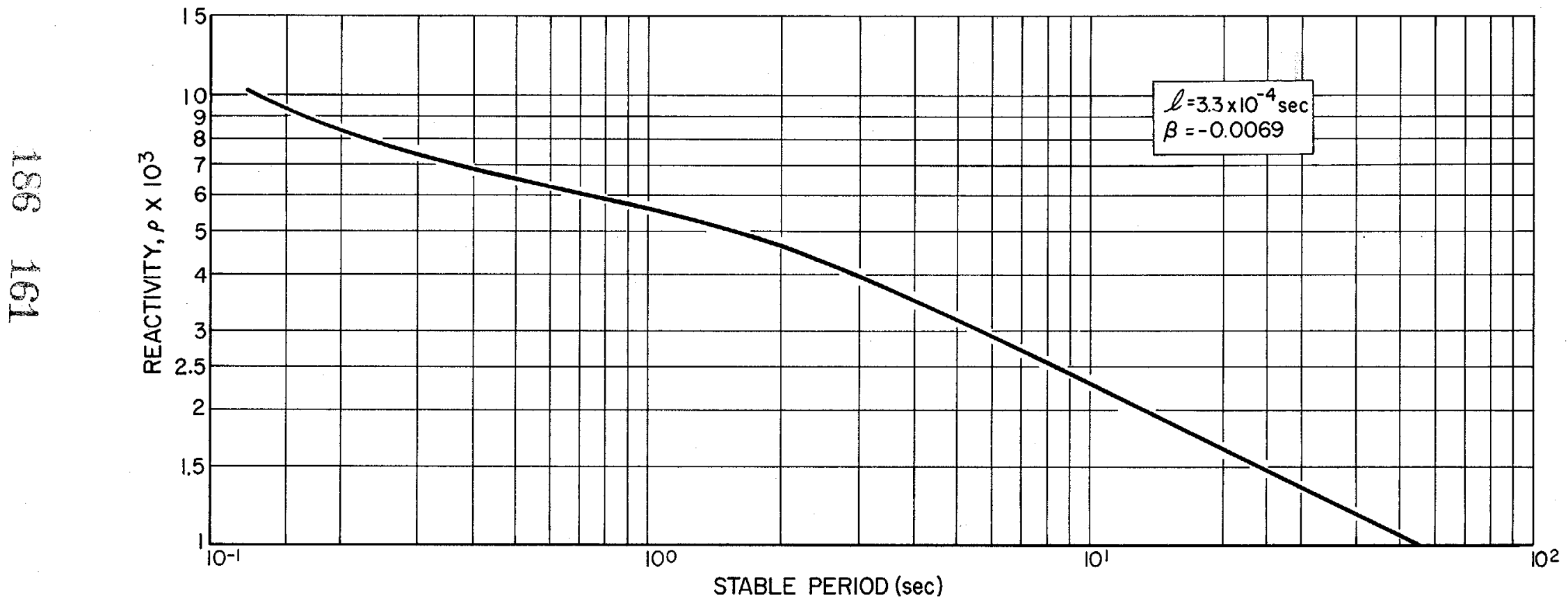

Figure 39. Stable Period as a Function of Excess Reactivity 


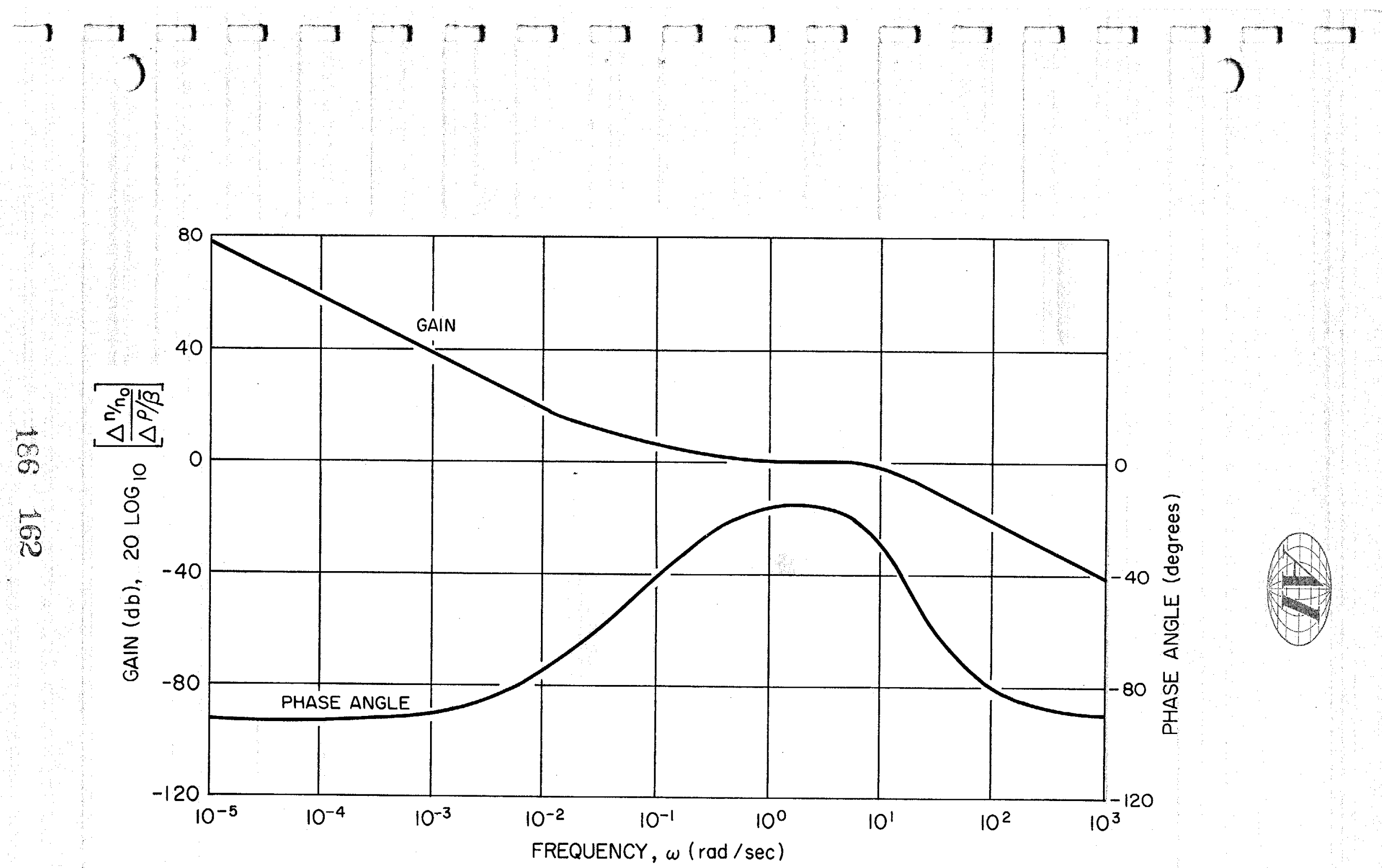

Figure 40. Zero-Power Reactor Transfer Function 


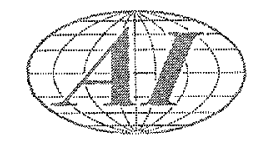

where

$$
\begin{aligned}
\rho_{\text {ext }} & =\text { step input in reactivity } \\
H_{s s}^{\prime} & =\text { steady state delayed power coefficient (graphite) } \\
H_{s s}^{\prime \prime} & =\text { steady state prompt power coefficient (fuel plus sodium) } \\
p_{0} & =\text { initial power level } \\
H_{s s} & =H_{s s}^{\prime}+H_{s s}^{\prime \prime} .
\end{aligned}
$$

The above equation applies only after the initial fast transients have died out. In order to illustrate the long term dynamics, this equation is plotted in Figure 41 for a step change in reactivity of $0.1 \%$ for the reactor in an unirradiated state and also after the graphite has undergone radiation damage of $10^{21} \mathrm{nvt}$. For the unirradiated state the power rises on a very long period and ultimately reaches an equilibrium state after about $300 \mathrm{~min}$. For the irradiated condition the reactor power continues to rise due to the positive power coefficient. The power increase is so slow, however, that there is no safety hazard present. The rise in power is well within the corrective capabilities of operator action, power setback, and reactor scram. It merely represents an additional burden on the control system in the sense of requiring readjustment of control rods more often in order to regulate power level as accurately as desired.

\section{Short-Term Dynamics}

The short term dynamics including stability studies have been investigated using conventional feedback system techniques. It has been found that for the type of reactivity feedback mechanism present in the HNPF core, the reactor will always be dynamically stable (no undamped high frequency oscillations). An open loop Nyquist diagram is shown in Figure 42. It is seen that the phase shift is always less than 180 degrees, indicating stability at infinite gain margin. This indicates that dynamic stability exists regardless of the magnitude of the temperature coefficients and power level. A frequency response diagram is shown in Figure 43 of the full power (closed loop) transfer function. The peaking of the magnitude in the frequency response plot indicates some overshoot in the transient response. The response is not oscillatory, however, as the gain of the system is too low. Figure 44 shows the short term transient response for a step input of $0.1 \%$ reactivity as determined from the closed loop transfer function. 


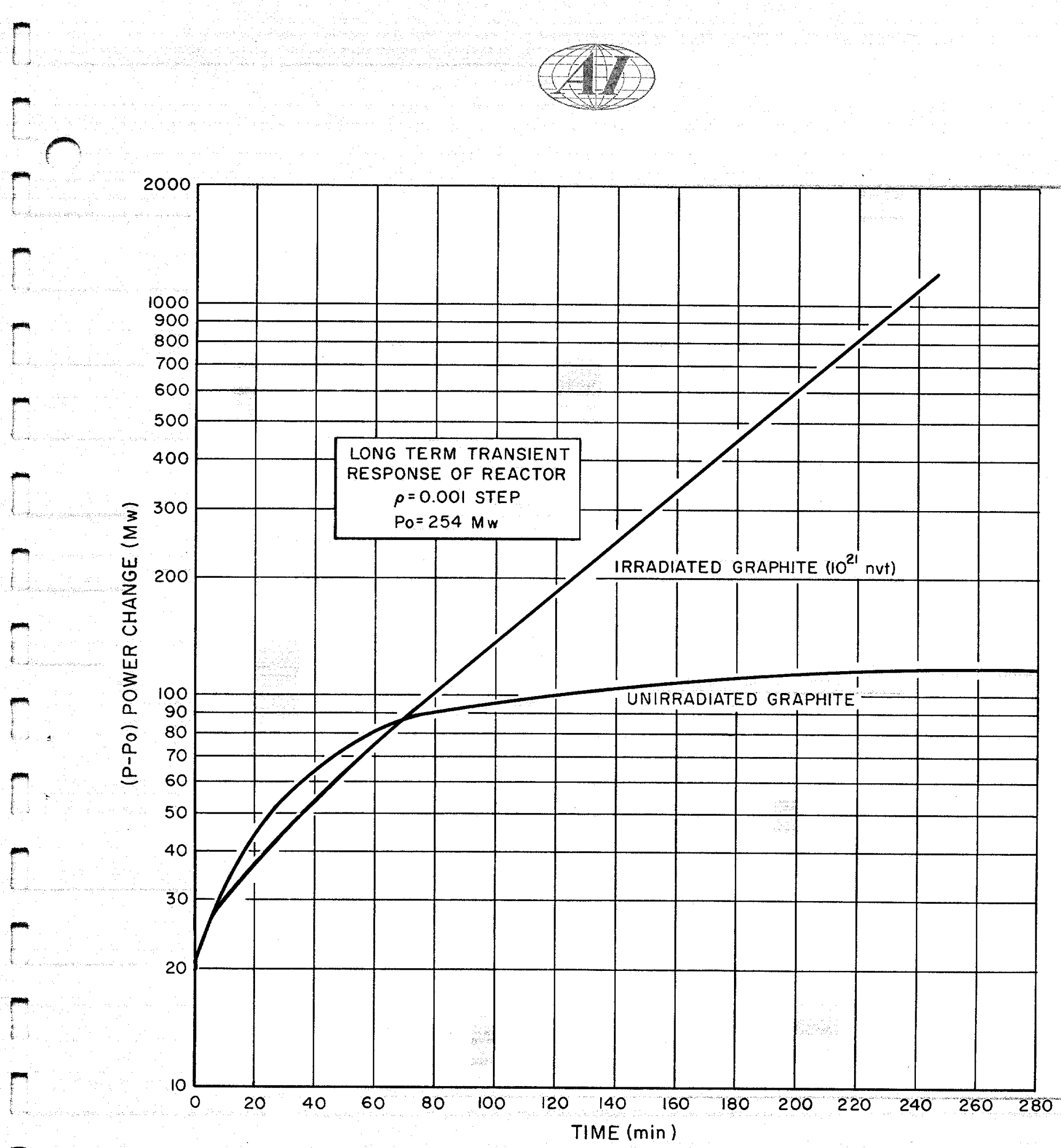

Figure 41. Long-Term Transient Response of Reactor 


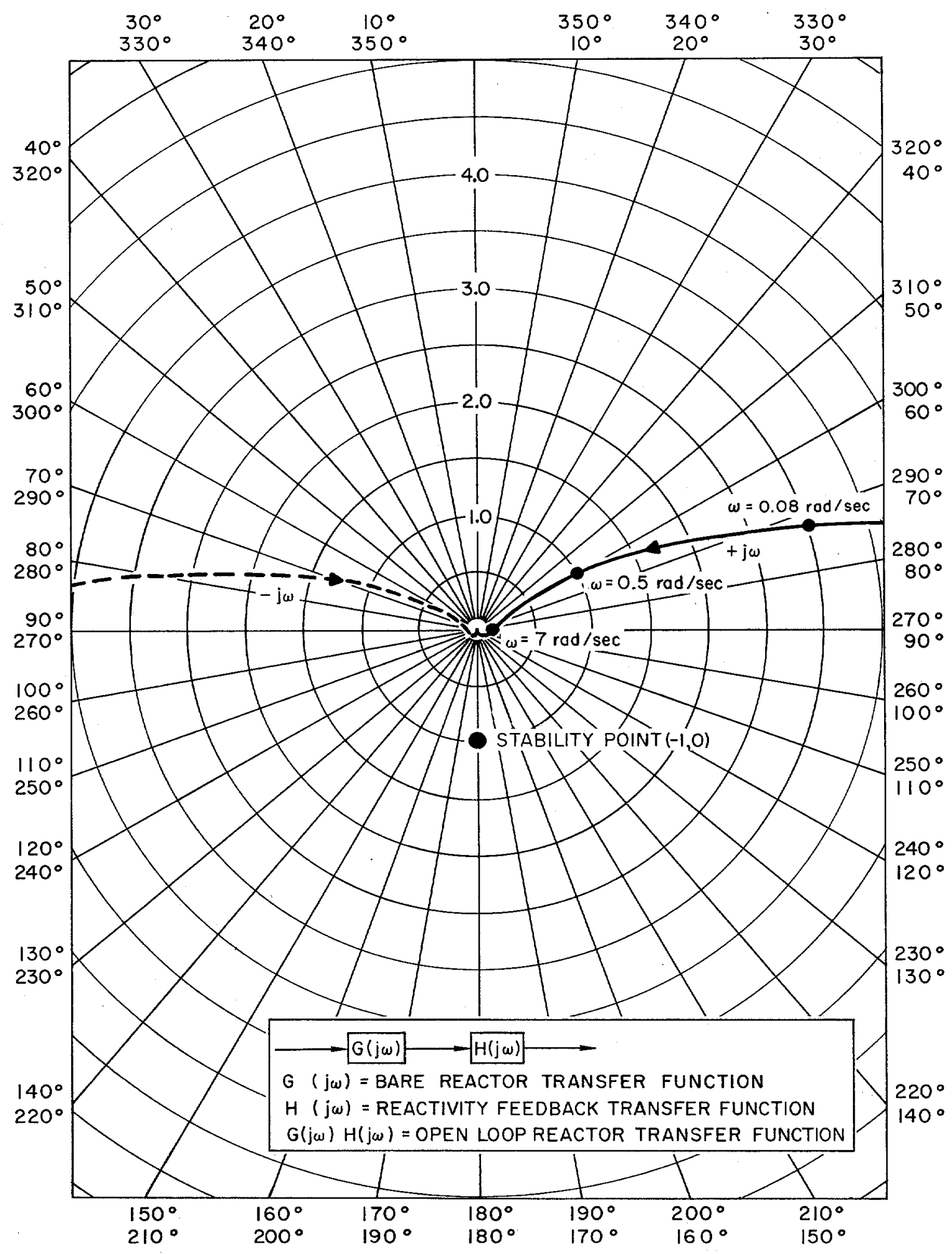

Figure 42. Open Loop Reactor Transfer Function 


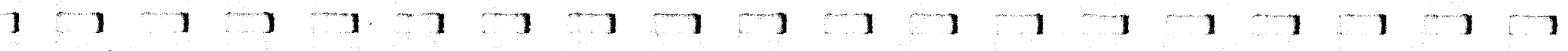

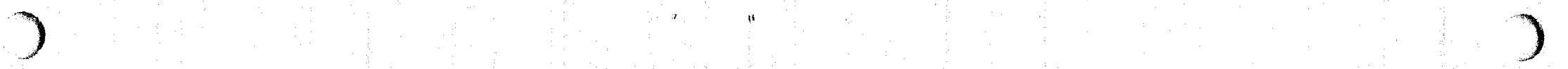

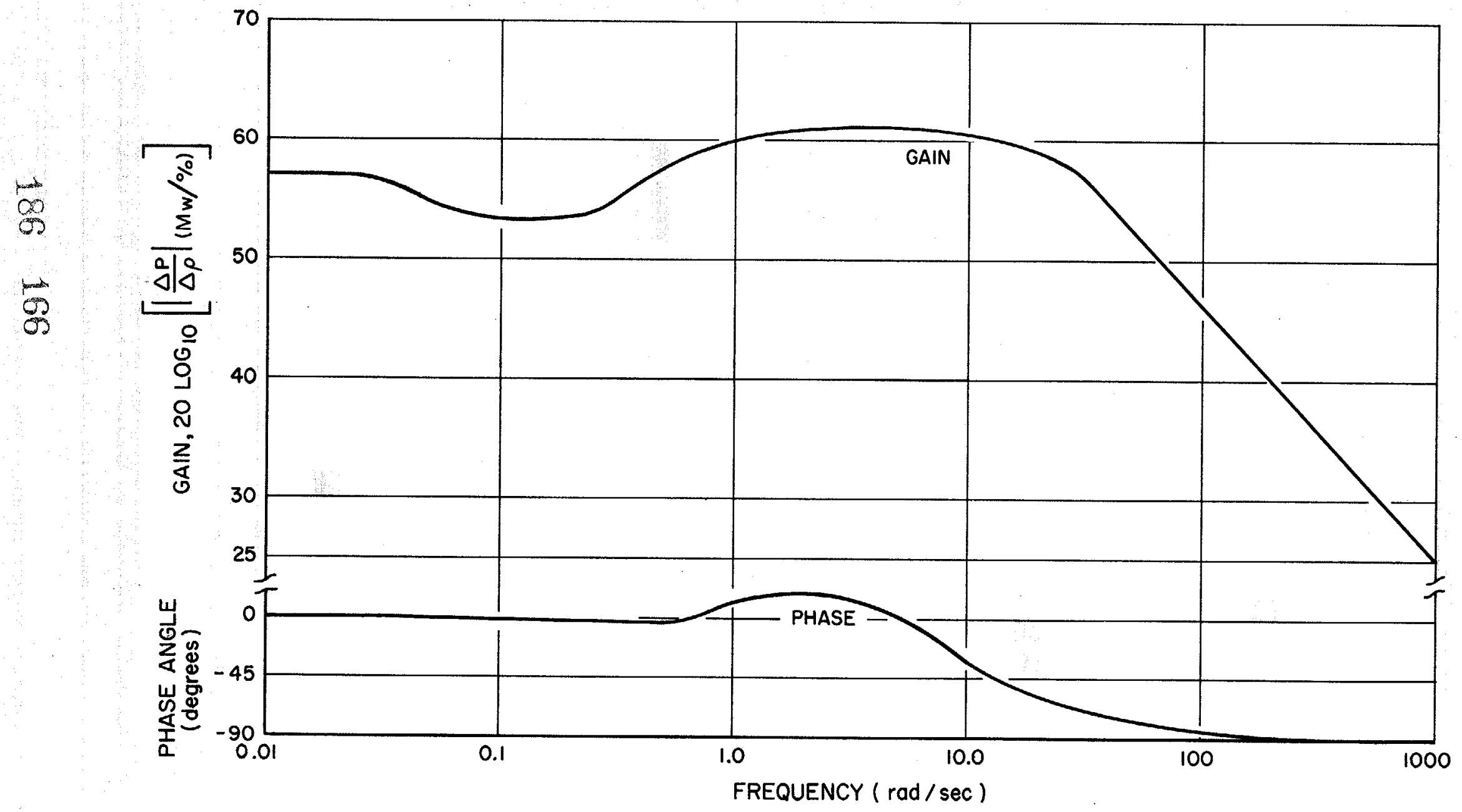

Figure 43. Full Power, Full Flow Transfer Function of Reactor Core 


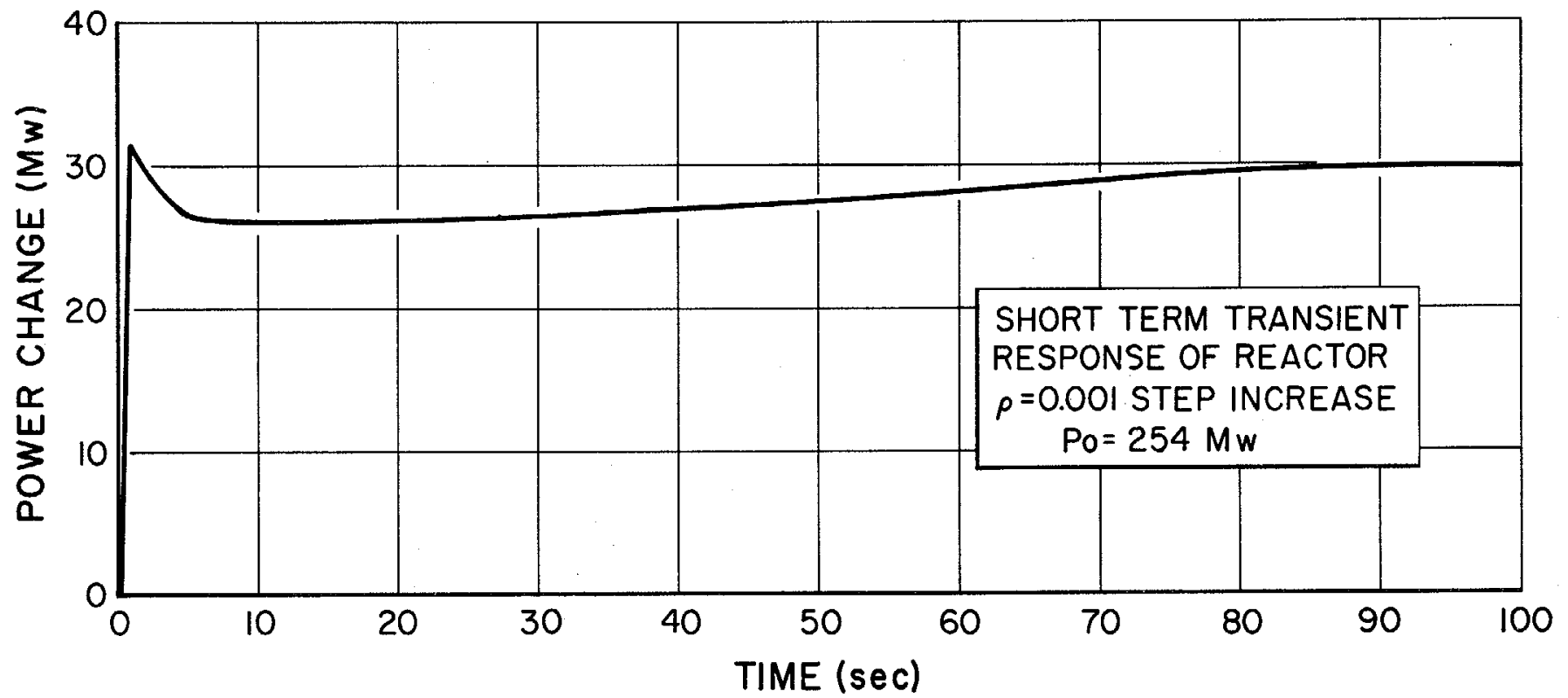

Figure 44. Short-Term Transient Response of Reactor 



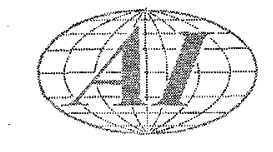

The fuel-channel-outlet coolant temperature is used as a sensing signal for setback and scram action in the protective system because the fuel element temperature is not measured in actual practice. The selection of the maximum temperature allowable during a transient condition is based upon consideration of the following factors:

a) Prevention of thermal damage to the process tube or moderator cans as well as to the external system.

b) Maintenance of margin of safety between allowable maximum fuel temperature and melting point of the U-Mo fuel, and between maximum clad temperature and NaK boiling point

c) Maintenance of a reasonable margin between normal operating ranges of the control system and the protective system

d) Prevention of sodium boiling.

Protective action is initiated so that any temperature excursion after the control rods have been reinserted by setback or scram action will not allow the sodium temperature at the fuel-channel outlet to exceed the following values: [slow transients are associated with relatively long reactor periods (>20 sec), and fast transients are associated with relatively short reactor periods $(<20 \mathrm{sec})$.]

a) Setback

1) $1000^{\circ} \mathrm{F}$ for slow transients

2) $1050^{\circ} \mathrm{F}$ for fast transients

b) Scram

1) $1100^{\circ} \mathrm{F}$ for slow transients

2) $1150^{\circ} \mathrm{F}$ for fast transients

In addition, trip levels are adjusted so that the maximum fuel temperature is kept below the fuel melting point $\left(2038^{\circ} \mathrm{F}\right)$; and the maximum clad temperature stays well below the boiling point $\left(\sim 1600^{\circ} \mathrm{F}\right)$ of the $\mathrm{NaK}$ bond. A brief description of the methods used in reactor power and temperature transient studies is contained in Appendix B. 


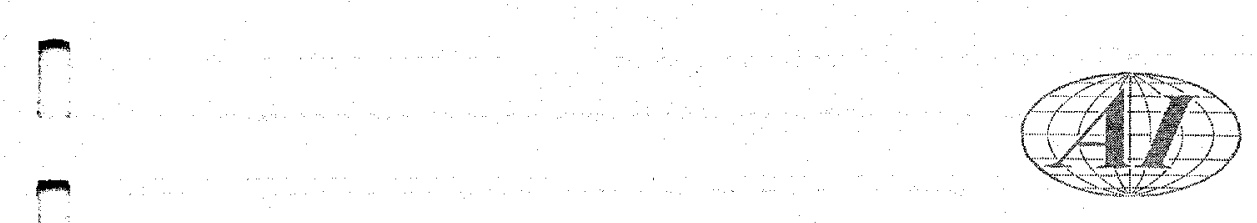

\section{A. STARTUP TRANSIENT FROM SOURCE LEVEL}

The startup transient is incurred by an unchecked rod withdrawal starting with the reactor initially at source level. The resulting short reactor period allows the power level to become undesirably high in a short period of time; and if the shim-regulating rod withdrawal continues unchecked, the ensuing high power level would produce thermal damage to the core components.

Transients resulting from each of two reactivity insertion rates have been considered; one being the transient occurring with the rods in their peak-reactivityworth region $(0.03 \% / \mathrm{sec})$, and the other being the transient with the rods in a position of lesser reactivity worth $(0.01 \% / \mathrm{sec})$. Figures 45 and 46 show reactor power level, fuel and coolant temperatures for these two startup transients with reactor scram caused by a neutron-flux low-level trip from the power-flow ratio circuits (Figure 47). Several protective actions would act to prevent the startup transient from ever reaching the low level trip point. These are:

1) An alarm from either of the two low-level or the two high-level period channels in the nuclear instrumentation system (See Figure 22), and subsequent operator manual correction, occurs when the reactor period is as short as $15 \mathrm{sec}$.

2) Rod setback from either of the high-level period channels occurs when the reactor period is as short as $10 \mathrm{sec}$.

However, in order to determine the effects in the reactor caused by scram action, it has been assumed that these signals were inoperative during these two transients. It is to be noted that the time scale in Figures 45 and 46 starts with zero being that time at which the reactor has already reached $1 \%$ of the full-power neutron-flux level (see Appendix B).

The results of these transients show that although there is an overshoot in reactor neutron flux, the fuel and coolant temperatures experience a relatively small increase. It is significant to note that there is no overshoot in the fuelchannel-outlet coolant temperature and a nominal low-level trip of $\mathrm{N} / \mathrm{N}_{0}=0.20$ is adequate to prevent the sodium temperatures from exceeding $1000^{\circ} \mathrm{F}$. Also, the fuel temperature does not exceed its normal operating temperature. Thus, the protective system limits this transient so that no damaging conditions is imposed upon the reactor. 


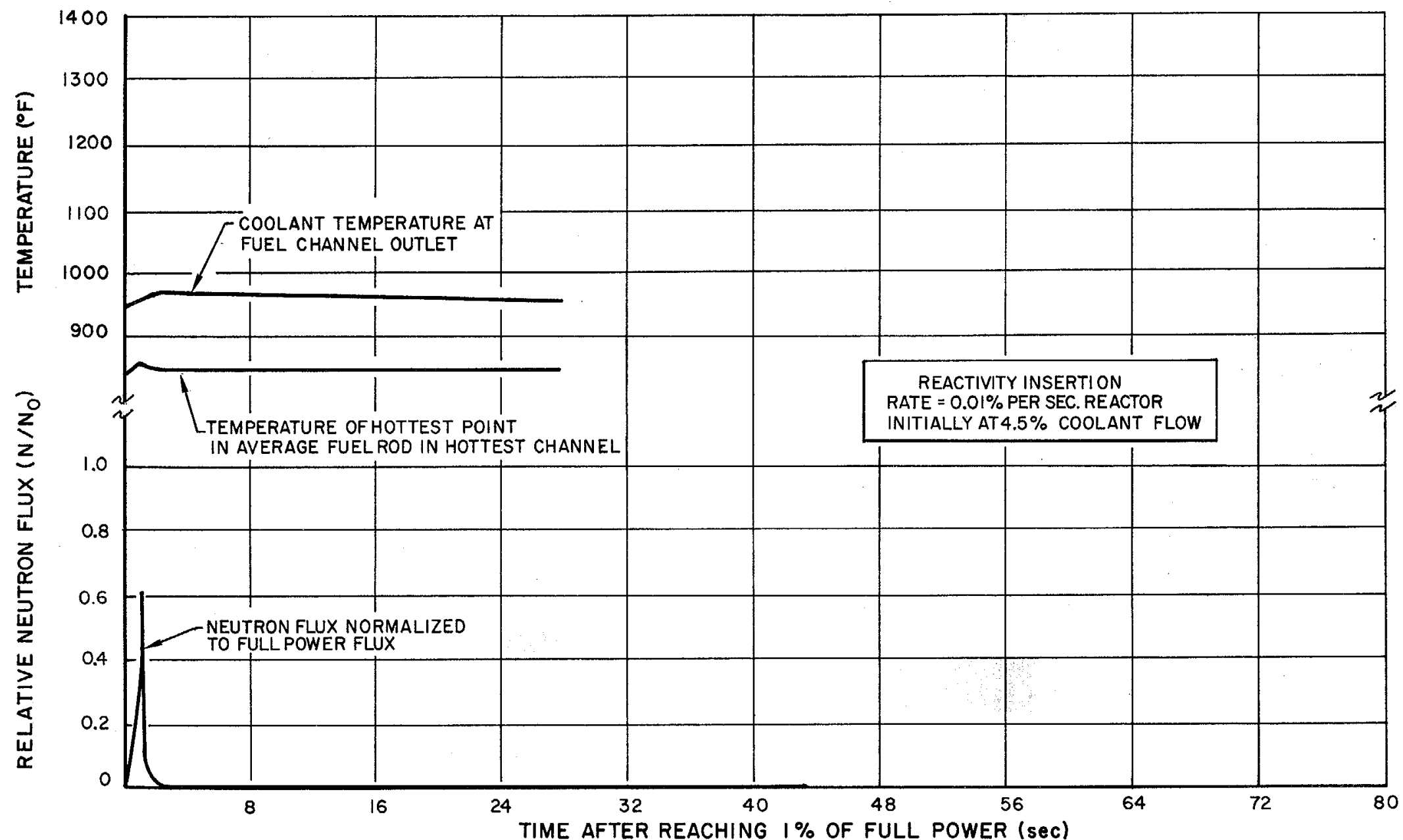

Figure 45. Temperatures and Relative Neutron Flux for Startup Transient with Protective-System Low-level Scram at $\mathrm{N} / \mathrm{N}_{0}=0.20$ 


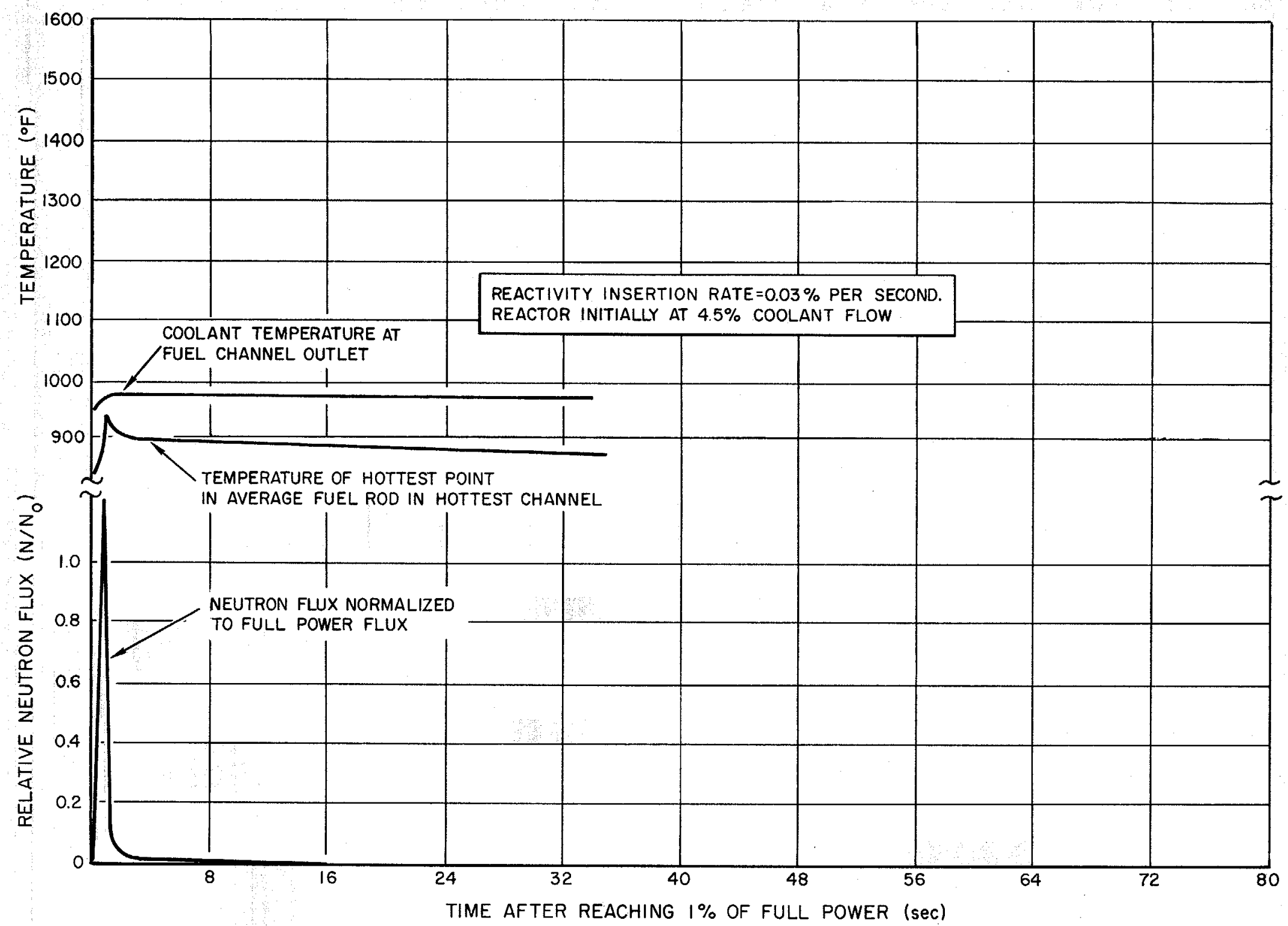

Figure 46. Temperatures and Relative Neutron Flux for Startup Transient with Protective-System Low-level Scram at $\mathrm{N} / \mathrm{N}_{0}=0.20$ 


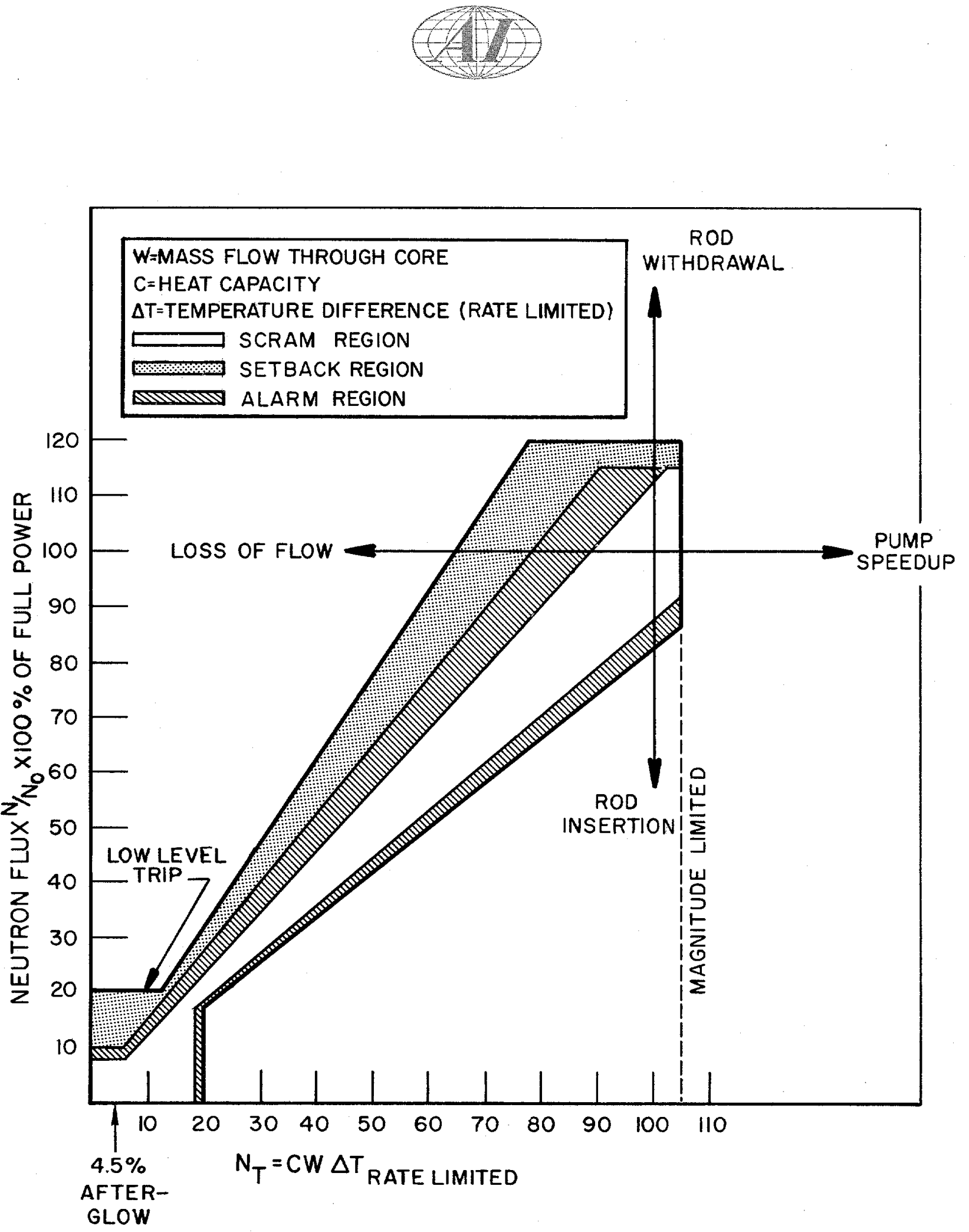

Figure 47. Power-Flow-Ratio Operating Curve 



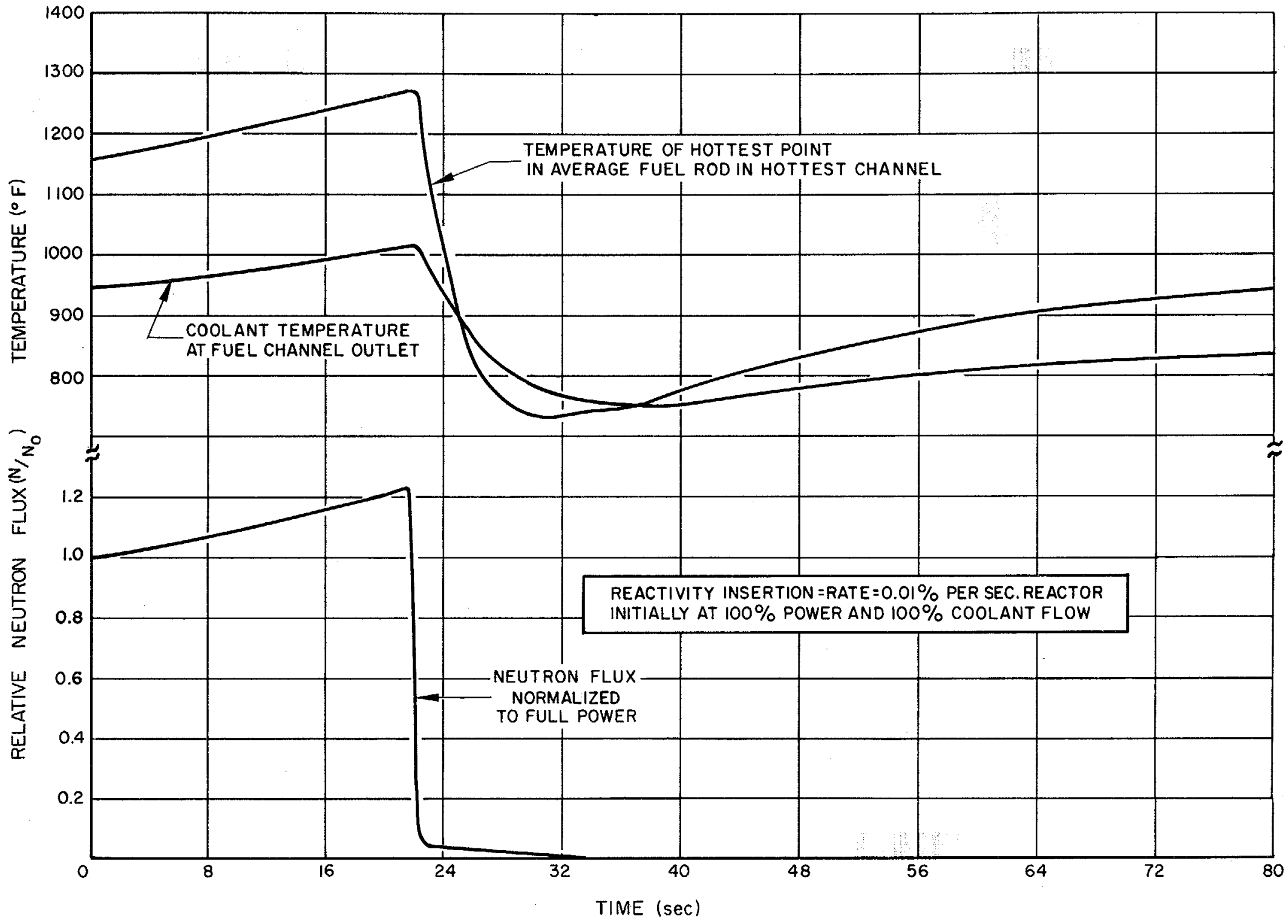

Figure 48. Temperatures and Relative Neutron Flux for Rod-Withdrawal

Transient with Protective System Power-Flow-Ratio Scram at

$$
\left[\left(\mathrm{N} / \mathrm{N}_{0}\right)-\left(\mathrm{V} / \mathrm{V}_{0}\right)\right] /\left(\mathrm{V} / \mathrm{V}_{\mathrm{o}}\right)=0.25
$$




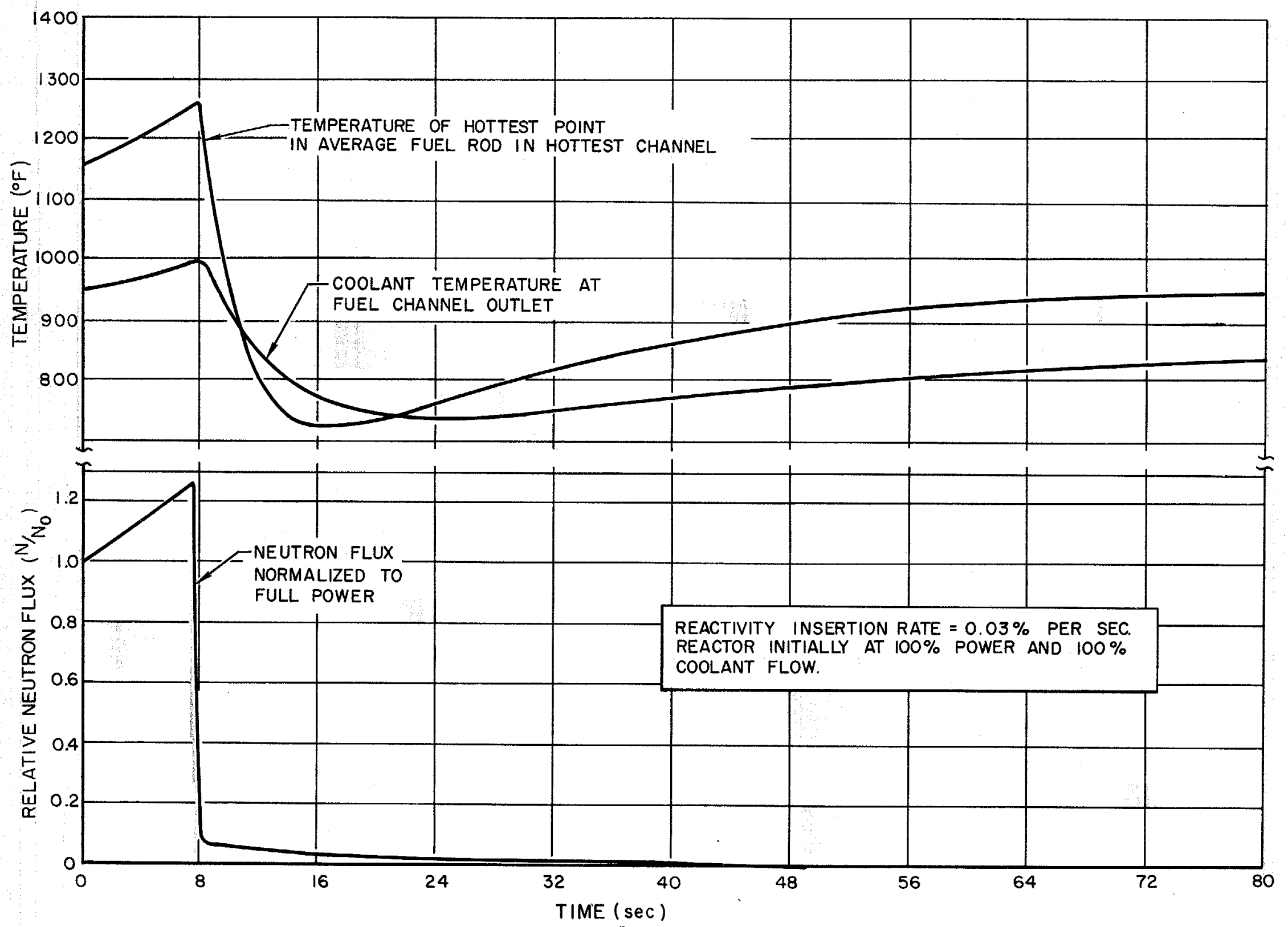

Figure 49. Temperatures and Relative Neutron Flux for Rod-Withdrawal

Transient with Protective System Power -Flow-Ratio Scram at

$$
\left[\left(\mathrm{N} / \mathrm{N}_{0}\right)-\left(\mathrm{V} / \mathrm{v}_{0}\right)\right] /\left(\mathrm{V} / \mathrm{v}_{0}\right)=0.25
$$




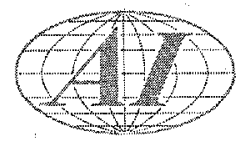

The several protective actions which would prevent the rod withdrawal transient from reaching the power-flow-ratio trip are as follows:

1) An alarm signal occurs when fuel-channel-outlet coolant temperature exceeds $975^{\circ} \mathrm{F}$. Subsequent operator action could prevent the scram from occurring.

2) An alarm signal (and possible operator manual corrective action) occurs when the power-flow ratio exceeds alarm limits (Figure 47).

3) Rod setback occurs when the power-flow ratio exceeds setback limits (Figure 47).

If the power-flow ratio scram were to fail completely, the following backup protective signals would automatically shut down the reactor before any core damage occurs:

1) Rod setback occurs when fuel-channel-outlet coolant temperature exceeds $1000^{\circ} \mathrm{F}$.

2) Rod scram occurs when the power-flow ratio exceeds scram limits. See Figure 47.

3) Rod scram occurs when fuel-channel-outlet coolant temperature exceeds $1025^{\circ} \mathrm{F}$ or a rate of change of $50^{\circ} \mathrm{F}$ in any one hour.

\section{ROD-WITHDRAWAL TRANSIENT FROM LOW REACTOR POWER LEVEL}

A rod-withdrawal transient from low reactor power (when the reactor plant is operated manually or semi-automatically), can behave quite differently from an excursion from high power and high flow rates, because of the low sodium flow rate. During startup after a scram, control rods and pump speeds are both raised smoothly in small increments to bring the power level and sodium coolant flow rate high enough (usually greater than $20 \%$ ) so that the complete automatic control system can be placed in operation. An excursion during this procedure would be a slow transient with a relatively long reactor period since the prompt negative temperature coefficient of the fuel opposes the power increase. The rod withdrawal transients for low power and flow and utilizing a $0.01 \%$ and $0.03 \% / \mathrm{sec}$ peak-reactivity insertion rate and a fuel-channel-outlet 



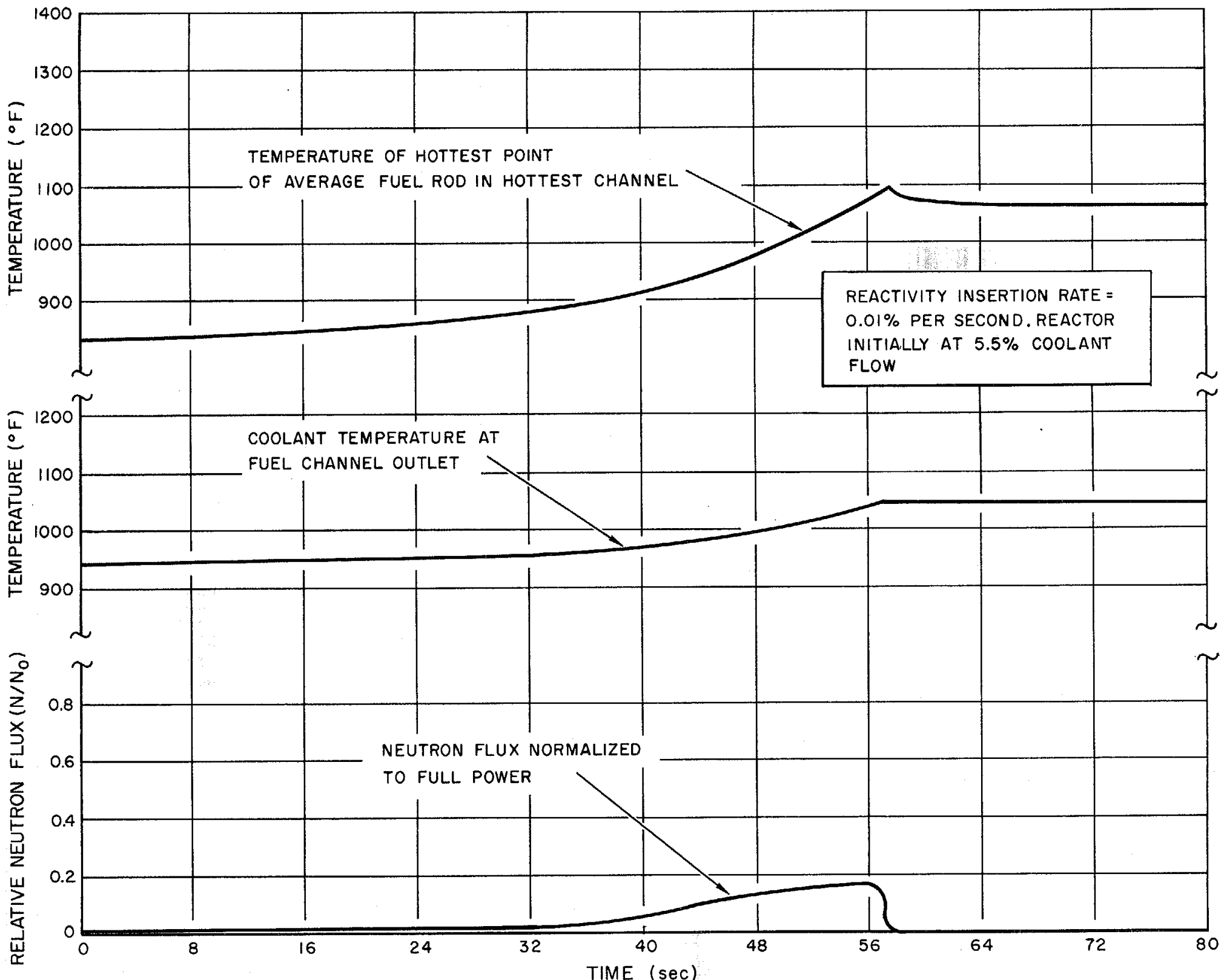

Figure 50. Temperatures and Relative Neutron Flux for Rod-Withdrawal

Transient with Protective System Coolant Temperature Scram at Coolant Temperature of $1025^{\circ} \mathrm{F}$ 


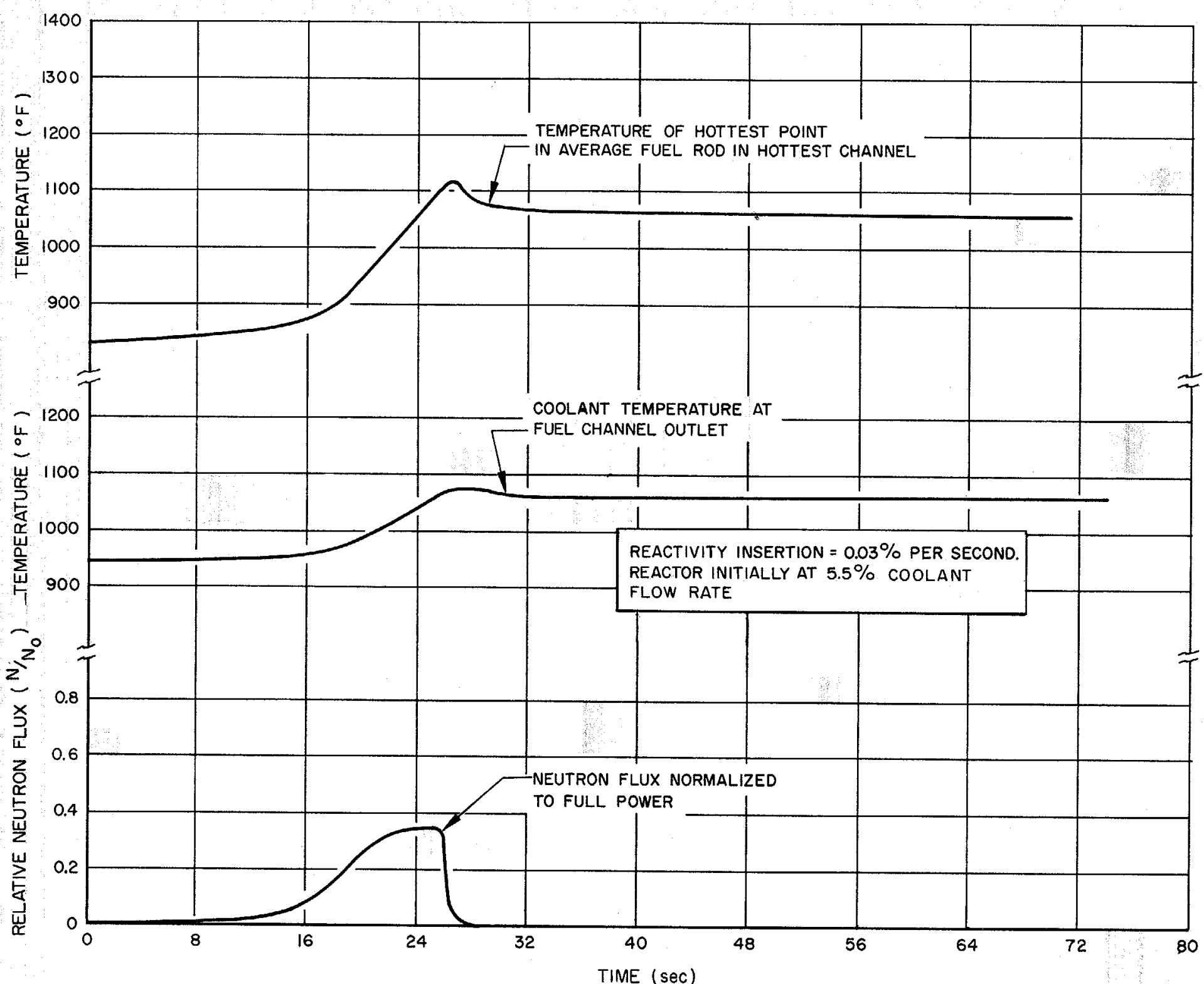

Figure 51. Temperatures and Relative Neutron Flux for Rod-Withdrawal Transient with Protective System Coolant Temperature Scram at Coolant Temperature of $102.5^{\circ} \mathrm{F}$ 


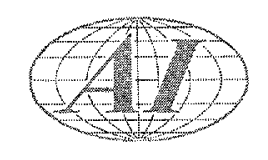

2) A break in the continuity of the magnetic coupling between the pump drive motor and pump impeller

3) A malfunction of the primary flow computers or controllers

4) A mechanical failure of a primary coolant pump

5) Failure of the operating personnel to properly control the pumps while the plant is under manual or semiautomatic operation

Figure 52 shows the results of analog computer studies of this transient starting from 100\% reactor power and 100\% coolant flow rate. The reactor is scrammed by the power-flow ratio circuit upon loss of forced convection flow rate, thus limiting the outlet coolant temperature to $1000^{\circ} \mathrm{F}$ and the maximum temperature of the average rod (analog mockup) to less than $1200^{\circ} \mathrm{F}$. Figure 53 illustrates the rate of decay of coolant flow through the reactor core.

The protective alarm and setback which would precede the power-flow ratio scram are as follows:

1) An alarm signal occurs when the power-flow ratio exceeds alarm limits (Figure 47).

2) Rod setback occurs when the power-flow ratio exceeds setback limits (Figure 47).

If the power-flow ratio scram circuit were to fail completely, the following backup protective circuits are available to prevent core damage:

1) An alarm signal (and subsequent operator manual correction) occurs when the fuel-channel-outlet coolant temperatures exceeds $975^{\circ} \mathrm{F}$.

2) Rod setback occurs when the fuel-channel-outlet coolant temperature exceeds $1000^{\circ} \mathrm{F}$.

3) Rod scram occurs when the fuel-channe1-outlet coolant temperature exceeds $1025^{\circ} \mathrm{F}$ or $50^{\circ} \mathrm{F}$ in a one-hour time span.

4) Rod scram occurs on loss of electrical power to the coolant pump motors (any one of six pumps).

5) Rod scram occurs when the primary to secondary coolant flow ratio exceeds the allowable limits. 


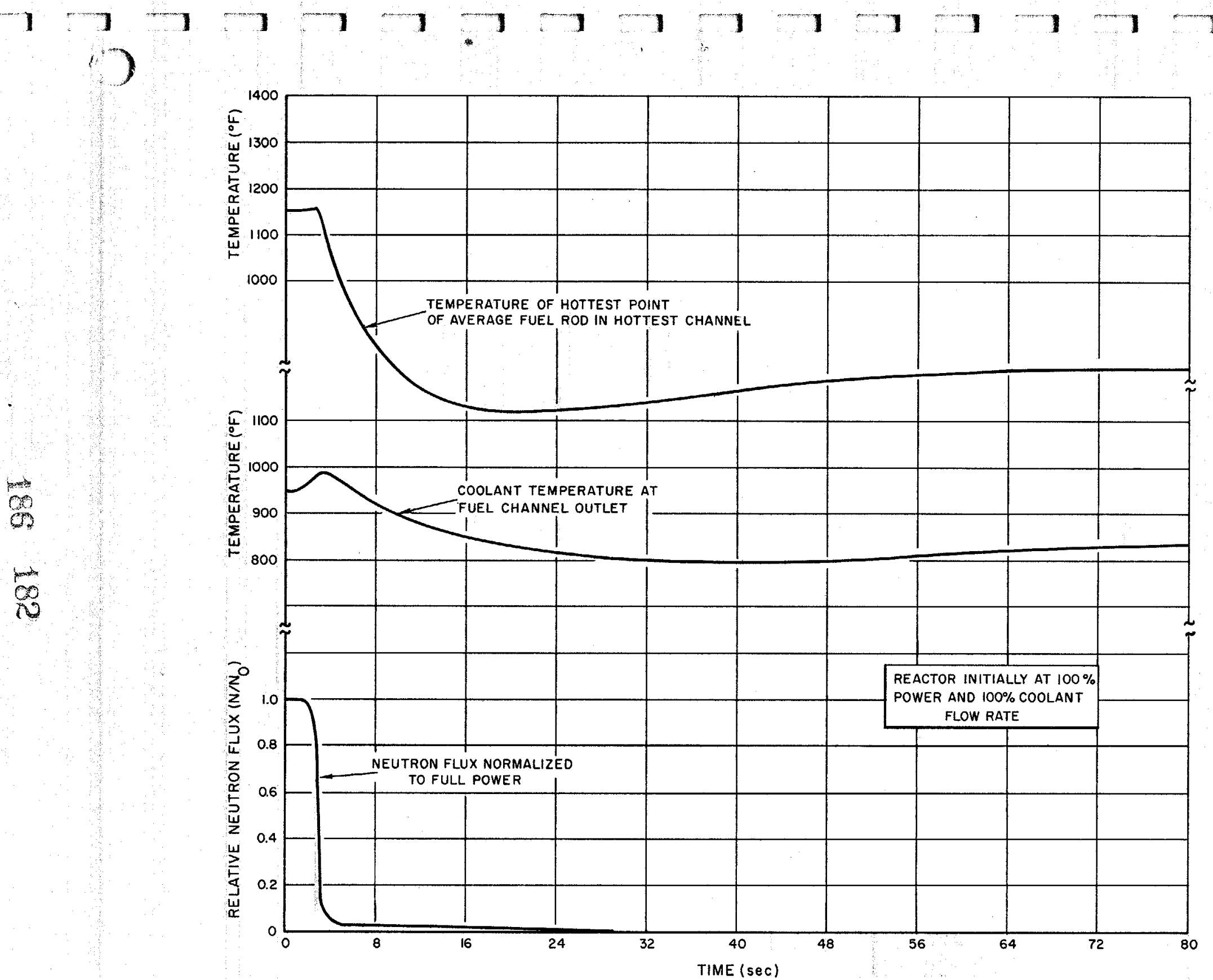

Figure 52. Temperatures and Relative Neutron Flux for Loss of PrimaryCoolant-Flow Transient with Protective System Scram from Power-Flow Ratio 


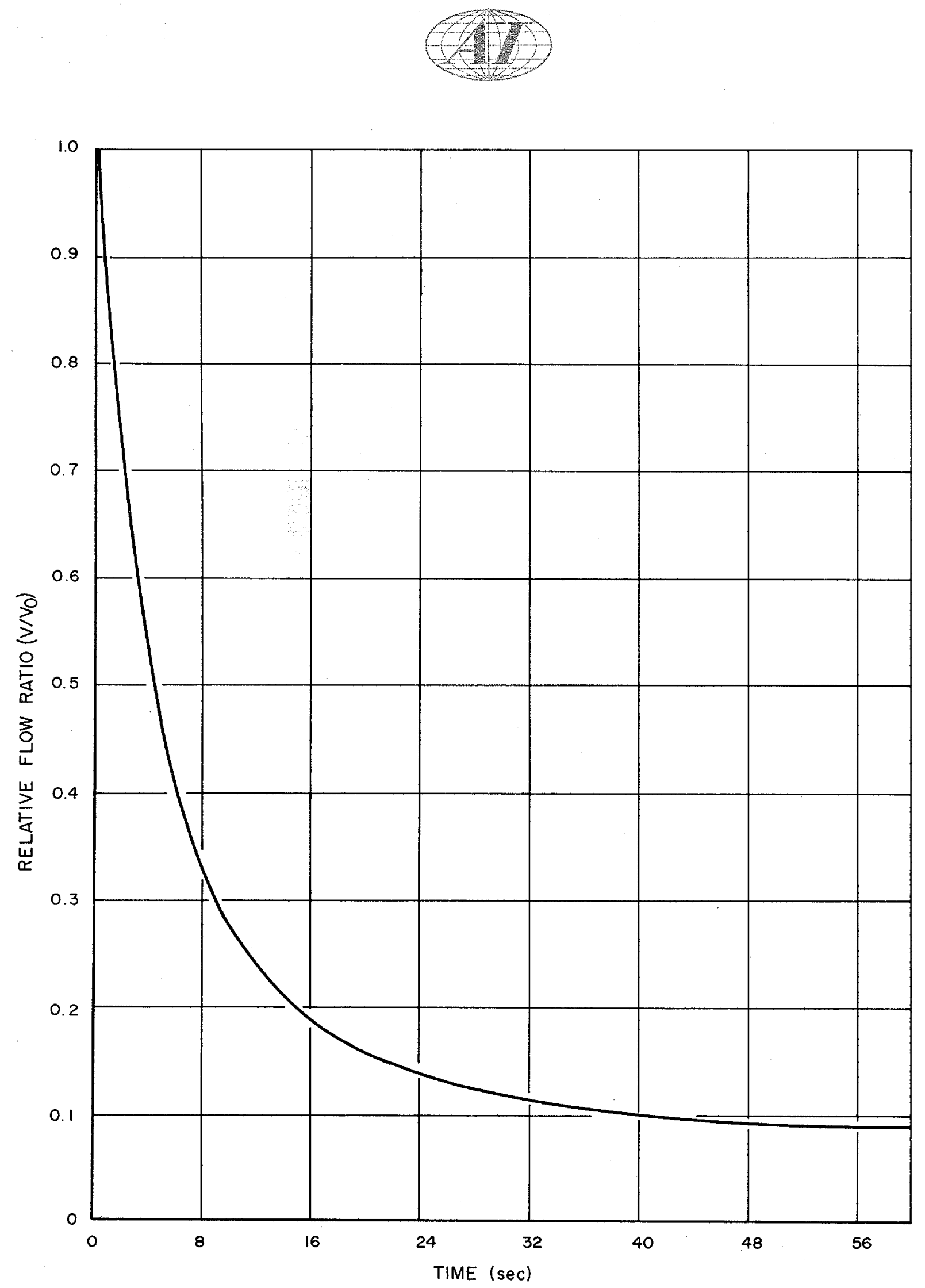

Figure 53. Flow Decay Curve Following Loss of Pumping Power for Primary Coolant 
E. REACTOR-INLET-COOLANT TEMPERATURE TRANSIENT

Normally, the automatic control system attempts to maintain the inlet coolant temperature at a set point between 557 and $607^{\circ} \mathrm{F}$ (depending on the plant load) by varying the primary-coolant-pump speed in each loop; however, should there be a failure in the control system or in the plant external to the reactor, a thermal unbalance could result in a coolant temperature transient too severe for the normal automatic control system to handle. The protective system would then take automatic action to prevent the situation from continuing to the point where it would cause damage to the reactor.

The reactor tends to resist rapid temperature changes as a result of its prompt-negative-power coefficient. Generally, high inlet coolant temperature is caused by unequal primary and secondary coolant flow (for instance, loss of forced secondary sodium flow). Thus, primary-to-secondary-coolant-flow ratio constitutes a primary scram signal, and heat-exchanger primary-outlet-coolant temperature constitutes a backup scram signal.

Protective action, taken to prevent thermal damage which would otherwise occur from inlet temperature transients, proceeds as follows:

1) An alarm signal and subsequent operator manual correction occurs when the reactor-inlet-coolant temperature exceeds $657^{\circ} \mathrm{F}$.

2) An alarm signal occurs when the reactor-inlet-coolant temperature drops below $530^{\circ} \mathrm{F}$.

3) Rod scram occurs when the reactor-inlet-coolant temperature (as measured at the intermediate heat exchanger outlet) exceeds $664^{\circ} \mathrm{F}$.

4) An alarm signal occurs when the fuel-channel-outlet coolant temperature exceeds $975^{\circ} \mathrm{F}$.

5) Rod setback occurs when the fuel-channel-outlet coolant temperature exceeds $1000^{\circ} \mathrm{F}$.

6) Rod scram occurs when the fuel-channel-outlet coolant temperature exceeds $1025^{\circ} \mathrm{F}$, or its rate of change exceeds $50^{\circ} \mathrm{F} / \mathrm{hr}$ for an extended period of time. 
7) Rod scram occurs when the primary-to-secondary-coolant-flow ratio exceeds the scram limits.

No analog results were shown here for inlet temperature transients in which protective system action occurs because of the large sodium transport time delay $(12 \mathrm{sec}$ ) from the intermediate heat exchanger to the reactor inlet plenum. The protective system would sense the trouble and scram the reactor long before the sodium transient reaches the reactor inlet plenum.

\section{F. PROTECTIVE SYSTEM SUMMARY}

1. Startup Interlocks

Prior to raising the safety rods for reactor startup, the following conditions must be satisfied:

a) The two count-rate meters indicate source neutron background.

b) All safety and shim-regulating rods are completely inserted in the reactor.

c) No condition prevails in the reactor that would initiates a scram or setback.

d) At least two of the three coolant circuits must be capable of operating.

e) The rail blocks preventing fuel handling gantry motion into the control rod drive area must be in place.

2. Setback Signals

During plant operation any one of the following situations would reduce the reactor power level by rod setback action:

a) High fuel-channel-outlet coolant tempe rature

b) High power-flow ratio

c) Short reactor period (below $1 \%$ full power)

d) Manual setback. 
3. Scram Signals

During plant operation, any one of the following situations will shut down the reactor:

a) Loss of primary coolant pump power in any one of three circuits

b) Low feedwater level in any one of the three circuits

c) Unbalance of primary and secondary coolant flow ratio in any one of the three circuits

d) High reactor inlet primary coolant temperature in any one of the three circuits

e) Low level of sodium in upper plenum of reactor core

f) High fuel channel outlet coolant temperature

g) High rate of change of fuel channel outlet coolant temperature

h) High or low reactor power to primary coolant flow ratio

i) Manual scram.

4. Scram Signal Actions

After receiving a scram signal the protective system takes the following automatic actions:

a) The safety rod magnets are de-energized and these rods fall into the core by gravity.

b) The automatic control system initiates a planned sequential for reactor shutdown.

c) All shim-regulating and safety rod motors are driven in.

d) The primary pump speed is immediately reduced to a minimum value.

e) The sodium convection flow controller is energized.

f) The turbine is tripped (after a suitable delay) and the steam-dump system is actuated.

g) Suitable annunciations are given. 


\section{TRANSIENTS WITHOUT PROTECTIVE SYSTEM ACTION}

Previous sections of this report have described the design of the nuclear facility, and the many protective measures that are taken to prevent any potential damage which might otherwise result from misoperation of the plant. Reactor transients with protective system action were discussed in Section XII. These transients are again considered in some detail in this section; however, the automatic protective system, which is designed to prevent them from occurring, is assumed to have failed. This total failure of the protective system then allows the transient to continue to the point where the inherent shutdown mechanism (within the reactor core itself) stops the transient. The termination of these transients would be by meltdown of the reactor core into a subcritical geometry with no release of radioactivity to the environment.

\section{A. SAFEGUARDS AGAINST NUCLEAR EXCURSIONS}

Before discussing unprotected transients (i.e., transients during which no automatic protective system action is taken) it is worthwhile to consider the improbability of any such occurrence taking place. Each of a large number of simultaneous failures must occur in order for an uncontrolled reactor transient to take place: failure of the plant control system, which in itself involves several independent failures; failure of the plant protective system which involves many independent failures; subsequent failure of the operating personnel to observe the situation and to take corrective action. All of these failures are required in order for an uncontrolled excursion to happen.

So as to guard against the possibility of such failures occurring, many features have been included in the design of the plant control and protective systems to make the reactor safe and reliable. The most significant of these features is the complete separation of the two systems. In this way, failures in the normal plant control system do not render the protective system inoperative. Separation of these two systems has been applied throughout, all the way from the measuring transducers, (neutron flux, sodium temperatures, sodium flow rates, etc.) to the control and shutdown actuators for the shim-regulating and safety rods. Thus, two completely independent systems axe provided to control and protect the plant: the plant control system which functions to regulate the variables in the plant, and 


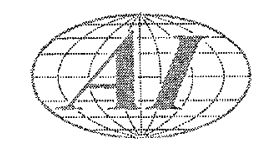

the plant protective system which functions only when the plant control system is unable to cope with a particular situation.

1. Plant Control System Safety Features

The plant control system has the normal function of regulating the reactor power, the coolant flow, the coolant temperatures, and the steam temperatures and pressures. If this system is functioning normally, no uncontrolled transient can occur. However, a failure in this system could allow an excursion in coolant flow rate or reactor power to take place, with the possible result of core overheating. The control system is designed to minimize this possibility by providing a monitoring system which is capable of placing the reactor in an "as is" condition. For example, if the monitoring system detected a failure in the neutron flux control system, the control rods would be left where they were when the control system failed, (rather than being driven either in or out of the reactor). This feature of the control system gives the plant operator a chance to repair the failure before the plant is shut down by the plant protective system; it also prevents control system malfunctions from changing plant variables in the wrong direction (such as driving the rods out rather than in, or decreasing rather than increasing the sodium pump speeds) because of the control system failure. This feature provides a considerable measure of safety, since the majority of failures would then render the system "as is"; and the operator could correct the situation manually until automatic control could be restored.

\section{Plant Protective System Safety Features}

The protective system is provided to guard against failures in the plant control system; it also provides back-up protection while the plant is on manual or semiautomatic operation.

The first automatic protective feature which would prevent many potentially uncontrolled transients from taking place is an interlock system. This interlock system prevents the manual operation of certain vital components if it is unsafe to do so. For instance, a startup interlock is provided so that none of the safety rods could be withdrawn (to initiate reactor startup) unless all of the shim-regulating and safety rods were completely inserted into the core. Another interlock provides that the shim-regulating rods cannot be withdrawn unless all of the safety rods are in a fully withdrawn and latched position. 


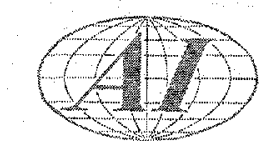

The second line of defense in the protective system is the plant alarm circuit. This circuit monitors each and every important variable, and annunciates any off-normal condition to the plant operator. If the off-normal condition is a slowly changing one, the operator will have time to correct it before the plant protective system takes automatic action.

The next line of defense is the setback system which, prior to the need for scram action, requires that all the shim-regulating rods be driven into the reactor until any off-normal situation has been corrected.

The final line of defense in the protective system is the scram system. If the other systems fail to correct the off-normal situation, reactor scram would effectively shut down the reactor by dropping all safety rods into the core and by running all shim-regulating rods in at their maximum rate.

Thus, many independent automatic actions are taken to ensure that the plant does not experience a transient which might cause excessive damage to any component.

Fail-safe circuitry has been used in the reactor protective system so that a failure in the circuitry itself would automatically initiate protective action. For example, a thermocouple which loses electrical continuity automatically sends a high-temperature signal to the reactor scram system; however, because of the coincident circuitry used, it takes at least two out of three signals from the parallel scram channels to cause an actual reactor scram. Thus, if one channel fails, the operator is immediately given a warning that one of the protective channels is not functioning properly - but the reactor is not automatically scrammed as long as the other two protective channels in the coincident circuit arrangement remain intact. If either one of these latter channels also gives a scram signal, the reactor would be automatically scrammed. Many sets of the se coincident scram signals are provided, as described in Section V.

Several different types of scram signals are used to initiate shutdown of the reactor in case of any particular transient, and for every potentially uncontrolled transient there are at least two independent sources of signals which would automatically scram the reactor in the event that such a transient is initiated. For instance, if the rods are continually withdrawn so that a "rod withdrawal accident" ensues, then the reactor would be scrammed first by a power-flow ratio signal or, secondly, by a high-temperature thermocouple signal. 


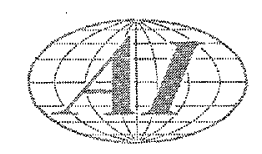

Testing circuitry is also provided to check the automatic protective system at regular intervals; any defective portions of the system would be observed during this period and would be corrected as needed.

\section{Inherent Safety Features}

In addition to the automatic safety features which have been designed into the control and protective systems, the reactor itself has many inherent safety features, many of which have been discussed previously. However, it is well to point out these features which would minimize the effects of an uncontrolled excursion if it were to take place.

All actuators such as control rods, pump speed changers, valve operators, etc., are particularly rate-limited so as to restrict the maximum rate at which the operating condition can be changed. If there is a malfunction or a manual misoperation resulting in control rods being driven out, the maximum rate at which they can be driven out is limited so that the reactor could not attain an extremely short reactor period during any given transient. This rate limiting on control rod motion is provided by geared-down induction motors such that the maximum rate of these motors is absolutely determined by gear ratios and by the electrical frequency.

The prompt negative power coefficient associated with the "Doppler" coefficient of reactivity in the fuel elements promptly resists any insertions of reactivity in the reactor, and thus limits the power level during any excursions which might take place. In addition, the large heat capacity of the upper sodium pool and the graphite moderator would absorb much of the heat from power excursions, and would thus prevent temperatures from changing rapidly.

Three independent sodium cooling circuits are provided so that at least one circuit is always available to remove afterglow heat from the reactor. Natural convection flow in any one of the three sodium circuits is adequate to remove the afterglow heat as long as a source of cooling is available in the steam generator. Also, the available storage of feedwater for the steam generators is adequate to remove afterglow heat without any external supply of feedwater cooling.

Inherent protection is afforded from three fronts against overpressurizing the reactor system as the possible consequence of sodium boiling during a nuclear 
excursion. The first of these protective fronts is against local boiling of the sodium in the fuel channels. This protection is provided by the large difference which exists between the normal maximum coolant temperature $\left(\sim 1000^{\circ} \mathrm{F}\right)$ and the coolant boiling temperature $\left(\sim 1600^{\circ} \mathrm{F}\right)$ at atmospheric pressure. This large temperature difference provides a large thermal storage capacity within the coolant to absorb any nominal upsurges in reactor power. Under normal operating conditions at atmospheric pressure the reactor power level would have to increase to almost three times its usual level (at a given sodium flow rate) if coolant boiling were to be initiated in the fuel channels.

The second protective front is against bulk boiling of the coolant in the upper plenum. The thermal storage capacity of this pool is adequate to prevent bulk pool boiling of the coolant for over 3 minutes if rated coolant flow prevails (over 1 hour with 5 percent coolant flow rate) and with local boiling occurring at the outlet from all fuel channels.

The inherently unstable behavior of sodium boiling in the fuel channels provides the third protective front against excessive pressurization of the reactor. Because of the friction and acceleration effects resulting from vapor formation, if coolant boiling were initiated in the fuel channels, "choking" due to "boiling instability" would starve the channel of coolant flow. This phenomenon makes it improbable that significant amounts of vapor could ever be generated in the system before melting of a large fraction of the fuel would reduce the core to a subcritical geometry. Fuel melting in this manner is the ultimate shutdown mechanism of the reactor.

A final protective feature is the sequence of physical failures which would occur to relieve excessive reactor pressures. The first in this sequence is the reactor vessel bellows which would fail physically if the internal reactor pressure were to exceed approximately $30 \mathrm{psig.} \mathrm{The} \mathrm{internal} \mathrm{pressure} \mathrm{would}$ then be relieved into the reactor cavity. The structural seal between the reactor cavity and the pipe tunnel (and intermediate heat exchanger cells) would fail if the pressure in the reactor cavity were to exceed approximately $30 \mathrm{psig}$. The internal pressure would then be relieved into the pipe tunnel and intermediate heat exchanger cells. 


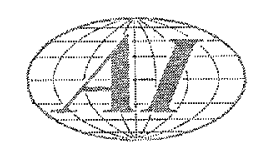

The gross volume of these regions into which pressure relief would occur is in excess of 180,000 cubic feet, an indication of the enormous capacity for absorbing potential over-pressurization. Since the reactor loading face shield would maintain its integrity with a pressure buildup of 50 psig in the reactor vessel, a safe margin of protection is afforded against the release of radioactivity as the possible consequence of pressurization of the reactor.

\section{B. ULTIMATE SHUTDOWN MECHANISM FOR UNCONTROLLED EXCURSIONS}

The ultimate shutdown of the reactor by fuel melting could only occur after the initiation of coolant boiling in the fuel channels. However, if reactor shutdown did not occur soon enough, sustained boiling of the coolant in the fuel channels could also lead to pool boiling of the sodium in the reactor upper plenum (with the subsequent possibility of pressurization of the reactor, and pressure relief, as discussed in the preceding paragraph).

Since pressurization of the reactor would depend on continued boiling of the coolant in the fuel channels, it is of considerable importance to determine if this could ever occur. Investigations of the hydraulic characteristics during coolant boiling in the fuel channels have shown that vapor formation within a fuel channel has a very significant effect on the total mass flow rate through that particular channel. This effect is the result of density changes, flow acceleration, and changes in frictional characteristics of flow with the vapor-liquid mixture. It arises from the following two effects:

1) The vapor-liquid mixture has a relatively low density, and is consequently quite buoyant. This effect tends to increase the mass flow rate.

2) The vapor-liquid mixture has a relatively high specific volume, and consequently must flow at a high velocity in order to maintain the mass flow rate. The acceleration to high velocity and the friction associated with high velocity tend to decrease the mass flow rate.

Which of these two effects dominates depends upon the power level and the pumping pressure applied across the core. The buoyancy effect is important only when the vapor fraction is very small and when the pumping pressure is relatively low (low flow rate). At low coolant flow rates (<30 percent of rated flow) where buoyancy dominates, a power increase causes the mass flow rate to 


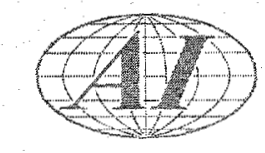

increase. At high flow rate ( $>30$ percent) the friction-acceleration effect predominates, and this effect is "auto-catalytic"; that is, a small power increase in this region is sufficient to trigger a rapid deterioration of the mass flow rate to a low value with subsequent fuel melting following shortly. This flow deterioration is often referred to as a "choking" of the flow in the channel due to "boiling instability" and is followed by ultimate shutdown of the reactor. Therefore, considering a particular transient, the results may be appreciably different depending on the initial condition from which the transient started. In order to more adequately understand the several possible results, many types of transients from various initial conditions have been investigated. These transients fall into two relatively distinct categories: the transients initiated from the high sodium flow rate, high power level (characterized by the highly unstable hydraulic characteristic), and those initiated from low power, low sodium flow rate (characterized by a quasi-stable hydraulic condition). Therefore, a typical transient from each of the two initial conditions will be described in some detail.

\section{Transient from High Sodium Flow Rate}

The ultimate shutdown mechanism coming into play during a transient with high sodium flow rate can be characterized by a rod withdrawal accident which is described in more detail in Section XIII-C (where the temperature and power level excursions are described up to the point where sodium boiling starts at the fuel channel outlet; previous to this point the transient is characterized by a relatively slow power level increase, and consequently a slow sodium outlet temperature increase). After about one minute following the start of the rod withdrawal, the fuel channel outlet temperature reaches the sodium boiling point. At flow rates in excess of about 30 percent of full flow, vapor formation results in a rapid increase in the pressure resistance across the fuel channel. This rapid increase in resistance causes a decrease in mass flow rate and hence the "autocatalytic" decrease in sodium mass flow rate in that particular channel takes place.

Two conditions are possible at this point: (a) all fuel channels reach the boiling point exactly at the same time; or (b) one fuel channel reaches the boiling point first, and the channel "choking" condition occurs in only this one channel. 


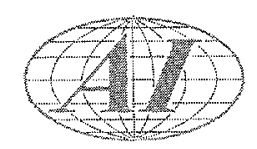

In the first case, all channels would decrease flow very rapidly and be left with a vapor blanket which is not adequate to remove the heat from the fuel element without a large fuel temperature rise. Simultaneous with the loss of liquid sodium from the fuel channels, a reactivity increase would occur because of the loss in sodium neutron absorption. This reactivity increase would result in an increase in power level which would immediately generate more heat within the fuel slugs. Because of the rapid increase in heat generation and the lack of adequate cooling, the fuel elements would increase in temperature very rapidly, with a significant portion of the slugs reaching the melting point (approximately $2000^{\circ} \mathrm{F}$ ). The fuel rods which reach the melting point first would be those located towards the center of the reactor core and at the outside edge of a fuel element (since the heat generation is highest in these rods because of the fuel disadvantage factor). Experiments have shown that as the fuel melting point is approached, U-Mo and stainless steel form a low melting point alloy which rapidly causes the fuel-clad combination to melt. Therefore, the result of this accident would be the rapid melting of a large fraction of the fuel within the core and the reduction of the core to a subcritical condition. (Calculations have shown that removing approximately 30 fuel elements from the central core region would render the core subcritical in its most reactive condition.) No pressure buildup, and therefore no disruption of the reactor, would occur.

In the second case mentioned, (b), where a single channel reaches the boiling point at its outlet first, the excursion would be slightly different. As soon as the coolant in the particular channel reaches the boiling point, hydraulic instability would occur in that channel. The resultant void formation in any single channel is insignificant in the over-all picture because it is only one out of approximately 155 channels. However, because of the loss of sodium cooling, the temperature of that particular element would increase very rapidly and within a few seconds reach the melting point. The fuel in this element would then drop out of the bottom of the process tube and into the lower plenum region. Because of the consequent loss of reactivity ( 0.21 percent per fuel element), the power level would drop; however, the reactor could stabilize at this lower power level (because of the prompt negative power coefficient) and then gradually increase again if the rod withdrawal continued. As soon as the next fuel channel reached the boiling point, the same process could continue until a sufficient number of 


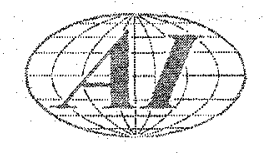

fuel elements were melted to render the core subcritical. In any event, the upper pool could not reach a boiling condition because the coolant in the fuel channels themselves cannot sustain boiling long enough because of hydraulic instability in the channels.

Thus, it is seen that in both cases of high coolant flow rate considered, hydraulic instability precludes the possibility of pressure buildup in the reactor as the result of liberating sodium vapor during the transient.

2. Transient From Low Sodium Flow Rate

Because of the stabilizing effect of sodium voids (due to the predominance of buoyancy effect) at low flow rates, the reactor behavior which can be expected from a transient having this initial condition is significantly different from that experienced for a transient starting from high sodium flow rates. The dividing line between low sodium flow rates and high sodium flow rates is at about 30 percent of rated sodium flow. For purposes of studying this nuclear excursion, consider that the reactor is operating in a steady-state condition at 10 percent flow, 10 percent power, and that an uncontrolled withdrawal of control rods occurs.

An idea of the behavior of the sodium flow within the fuel channel subsequent to reaching the boiling point can be obtained by referring to Figure 54 . At the beginning of the transient the reactor power and flow are equal to a value of 10 percent of the rated conditions. As the rods are withdrawn, power level increases rather slowly and the power changes are resisted by the negative temperature coefficient within the fuel element. After several minutes, the sodium temperature at the channel outlet would reach the boiling point. At this time, the reactor would be in a condition (see Figure 54) given by the intersection of the boiling and nonboiling surfaces; that is, it would have a sodium flow rate of 10 percent and a power level of approximately 28 to 29 percent.

If it is assumed that the continued withdrawal of control rods results in further increase in power level, boiling will begin in the fuel channels and an estimate of the hydraulic behavior can be made from the reference figure. As the power level increases, the point on the boiling surface (Figure 54) must follow a constant $\Delta P$ line, since the pump pressure output is essentially constant, and not changing during this accident. Therefore, as power level increases, 


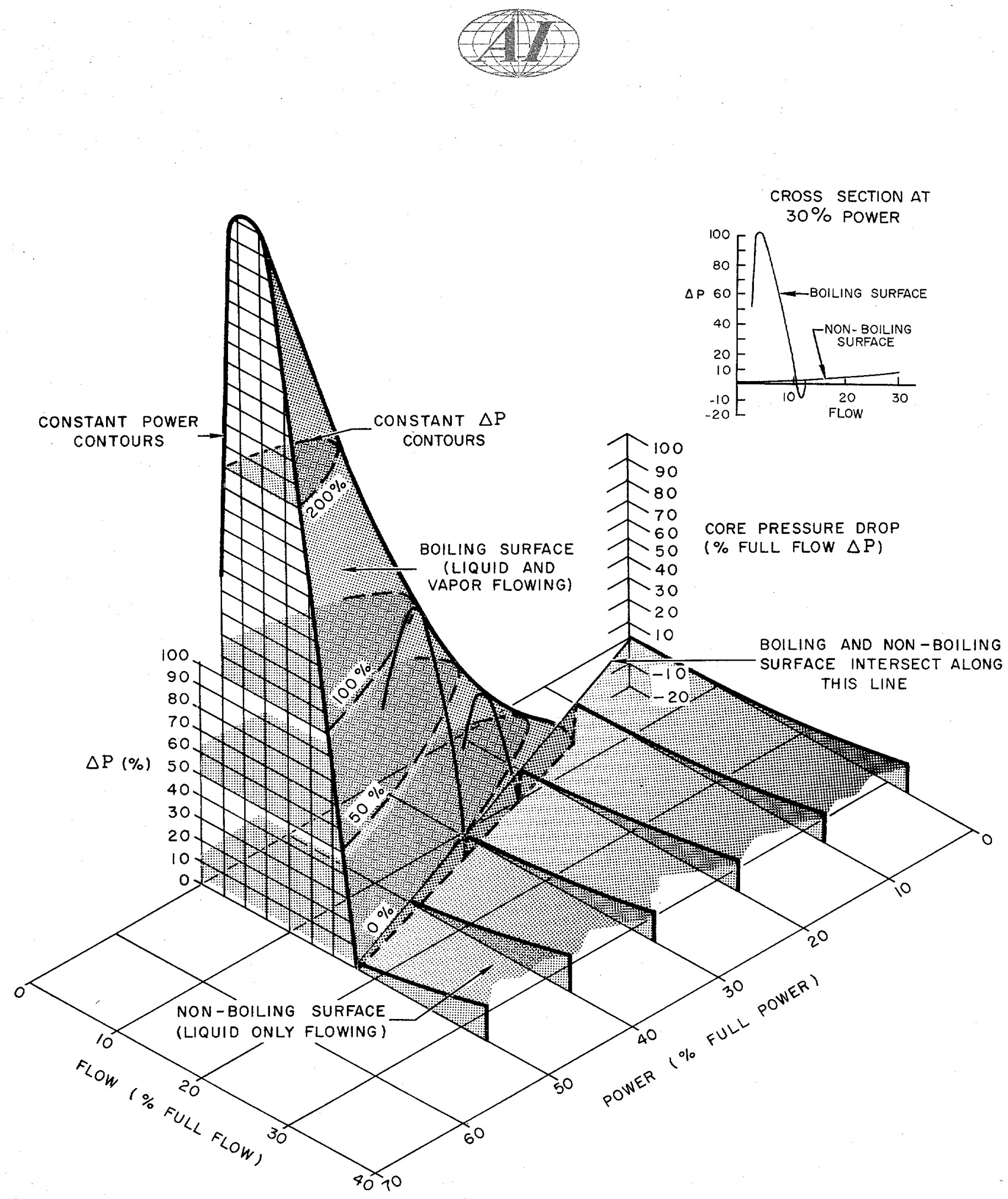

Figure 54. Core $\triangle P$ as a Function of Power and Flow in HNPF Center Channel 


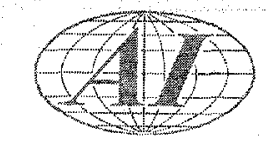

the point on the boiling surface moves along a constant $\Delta P$ line in the direction of the power increase on the boiling surface. Because of buoyancy, the flow also will increase. Continued power increase would cause a significant increase in the coolant flow rate as well as increasing the flow resistance across the fuel channel. Subsequent to reaching the minimum point on the boiling surface, the frictional drop across the channel would tend to decelerate the mass flow rate through the channel and rapidly decrease it to a choked condition. The flow in the channel would become unstable and no longer able to follow a constant $\Delta P$ line. There is a very narrow range of stability through which the flow rate can pass while on this very slow transient. If the rods continue to be withdrawn (as was postulated), the reactor would continue through this small quasi-stable region and then fuel meltdown would follow.

The second possibility is the highly improbable situation that the rod withdrawal is stopped at the time the point on the reference diagram reaches a quasi-stable boiling condition. The region of possible conditions whereby this can occur is very small; thus, the rods would have to coincidentally be stopped at exactly the right condition so that the power and the flow conditions were within this quasi-stable boiling region. If, in spite of its improbability, this situation did occur, the coolant flow would remain unchanged at approximately 10 percent of full flow and the outlet from the fuel channels would contain an extremely small amount of sodium vapor; adequate fuel element cooling would be provided and the elements would probably not melt.

It should be noted at this point that almost any action initiated by the operator would stop the quasi-stable boiling condition from persisting. For instance, if the control rods were withdrawn further, the core would melt down; if the control rods were inserted, the reactor temperature gradient would be reduced, the boiling stopped, and the reactor shutdown; if the pump speed in the main primary pumps is increased, the boiling will stop; if the pump speed is decreased by shutting the pumps off, the core would probably melt down (depending on the exact condition existing at the time); if the reactor inlet temperature is increased (or decreased) by changing the heat removal rate in the intermediate heat exchanger, the boiling condition will stop by fuel meltdown for by reduced temperature at the outlet from the fuel channels). Thus, it is seen that almost any action taken by the operator would cause this condition to cease and the boiling, therefore, to stop. 
If no action were taken, and the reactor coincidentally was left in this quasi-stable boiling condition, it would continue to generate vapor. Approximately 30 min after the sodium in the fuel channels reached the boiling point, the sodium temperature in the upper plenum would reach the boiling point and sodium vapor would then be generated in the plenum at a rate corresponding to no more than 1 percent of full power going into the latent heat of vaporization of the sodium. This sodium vapor in the upper gas volume would condense upon the cold lower surface of the top loading face shielding which is cooled by the organic coolant system. The organic cooling system is capable of condensing as much vapor as can be generated in this particular transient and would therefore prevent a pressure buildup within the reactor cavity region. Hence, this transient could continue completely unattended with no possibility of building up sodium pressure within the reactor cavity.

In addition, several other mechanisms which would prevent the reactor from remaining in this quasi-stable boiling situation could come into play in this transient. The first of these is the power coefficient which is positive under some operating conditions (see Section XI). With no control rod motion the reactor will tend to drift very slowly from any outgoing point. Therefore, the possibility that the reactor would stay within the quasi-stable boiling region is very slight (if not impossible) because of this positive power coefficient. The second of these is the probability of pump cavitation at high sodium temperatures. Because the inlet of the pump is fed from the reactor plenum, any increase in sodium temperature increases the probability of the pump cavitating. If pump cavitation did occur, the pressure output from the pump would be decreased and the stable boiling point on the curve would not be maintained. When the plenum reaches incipient boiling, the probability is very high that the pump will cavitate and that no significant amount of vapor could therefore be generated in the upper plenum.

To summarize this analysis of the ultimate shutdown mechanism, many different cases have been looked at with regard to their ultimate behavior in the event a transient should proceed without any automatic protective system action. In all cases studied, except the highly improbable low flow, low power, stable boiling case, the onset of hydraulic instability within the fuel channel and the subsequent melting of fuel elements would rapidly reduce the core to a subcritical condition and terminate the excursion. It is evident that these combined events 
form a very effective ultimate shutdown mechanism which precludes the possibility of the reactor cavity pressurizing under any of these events.

The results of an excursion from a very low sodium flow condition can be slightly different in that the reactor could reach a condition in which quasistable boiling might be attained. The improbability of this event, however, has been emphasized by pointing out that the control rods would have to be stopped at exactly the right spot and the reactor not permitted to drift from this condition [as would be expected due to power coefficient (or xenon) effects on reactivity]. Even though the reactor for some reason did not drift from the stable boiling region, the vapor generated by the boiling in the top plenum can be effectively condensed on the lower surface of the top loading face shield by the organic coolant system. It is concluded, therefore, that the HNPF reactor has a very powerful ultimate shutdown mechanism which is fully capable of shutting down the reactor without the possibility of release of any activity to the environment. 


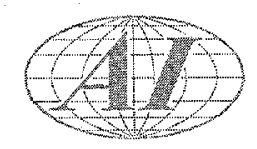

\section{NUCLEAR TRANSIENTS}

Every conceivable precaution has been taken to prevent the insertion of a large amount of excess reactivity into the HNPF reactor within a short amount of time. All ways in which reactivity insertion can take place are deliberately ratelimited so that the reactor cannot be put on an extremely short period. For example, the maximum rate at which the control rods can be driven is limited, so that it is not possible for the rods to insert reactivity at a rate greater than $0.03 \% / \mathrm{sec}$ when all of the rods are moving in the region of their peak reactivity worth. The fuel handling cask cannot be used to load and unload fuel elements into the core while the reactor is critical; i.e., no fuel element can be inserted inadvertently into a critical reactor, since all shim regulating rods and safety rods must be completely inserted into the core at the time any fuel loading operations take place. Thus, there does not appear to be any reasonable way in which a reactor fuel loading accident can take place. Therefore, large rapid-reactivity excursions are not further considered.

Slower nuclear excursions, however, might take place. In general, these are limited by the maximum rate at which either shim-regulating rods or sodium flow rate can be changed. Such excursions require a condition in which excessive power is attained with respect to the rate of coolant flow through the core. The rate at which power would change in such an excursion, however, is relatively slow because the prompt negative power coefficient associated with the "Doppler" effect in the fuel rapidly resists any insertion of reactivity. Thus, all excursions are characterized by relatively slow changes in power and temperature.

An electronic analog computer was used to study the effects of such reactor transients, which involve large unbalances between reactor power and coolant flow. The analog computer setup (Appendix B) was similar to that used for the protected accidents studied in Section XII, except that the protective system trip levels were not included; that is, the transients were allowed to continue to the point where the analog computer setup was no longer valid (boiling point of sodium or melting point of fuel). The ultimate shutdown mechanism described on the preceding pages would effectively terminate these excursions when the sodium reaches the boiling point. 
The transients presented are as follows: startup, rod withdrawal, and loss of forced circulation of coolant. The first two of the se end in the ultimate shutdown of the reactor by hydraulic instability and subsequent fuel melting; the third, loss of forced circulation, is terminated by reactor shutdown due to the prompt negative power coefficient before sodium boiling or fuel melting occurs. In order to emphasize the improbability that these transients would ever continue on to completion, the automatic protective features which must have failed are pointed out in each case.

\section{Startup Transient After Reactor Scram}

The startup transient, unlike a rod withdrawal accident which starts from an initial condition corresponding to critical operation, is characterized by a continuous unchecked withdrawal of shim-regulating rods starting from source level. The startup transient is the only transient in which short reactor periods can be attained with the reactor operating in the power range. This short period is attained because the power level starts from an extremely low value (determined by the neutron source and shutdown reactivity) and increases slowly at first, and more rapidly as the power range is approached. When the power range is reached, the delayed neutron precursor concentration is considerably lower than its equilibrium value and a large amount of reactivity has been inserted; therefore, the reactor approaches a "prompt critical" condition with the resulting short periods $(\sim 1 \mathrm{sec})$.

Since the analog computer was programmed only for the power range of operation ( $1 \%$ to $300 \%$ rated power), an IBM 704 digital computer code was needed to solve the reactor kinetics equations from source level to $1 \%$ of full power. The resulting delayed neutron precursor concentrations, reactivity, and the reactor period were then used as the initial conditions for the analog computer study starting at $1 \%$ of rated power. Since the reactor behavior in the power range is the only part of interest, the power transient obtained from the digital computer (below $1 \%$ rated power) is not included. It should be noted, however, that not less than 4.5 min would be required to withdraw the shim-regulating rods to the point of criticality, plus an additional time increment of at least 1 min to get to the $1 \%$ power level if all of the rods are being withdrawn simultaneously. The reactor is assumed to start from convective flow conditions with rated temperature gradient, corresponding to restarting the reactor following a scram. 


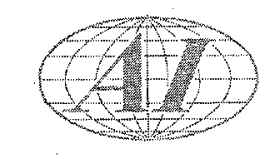

The transient (Figure 55) is shown to the point where the coolant temperature in the hottest channel reaches the boiling point $\left(1620^{\circ} \mathrm{F}\right)$. At this point, the outlet coolant temperature in the average channel would have risen to $1570^{\circ} \mathrm{F}$, with the temperature of the sodium in the upper plenum rising to only slightly higher than the initial value of $945^{\circ} \mathrm{F}$.

A startup transient as depicted here assumes that the following protective devices have failed or are ignored by operating personnel:

a. Below $1 \%$ Rated Power:

1) An alarm indicating that the reactor period has reached $15 \mathrm{sec}$.

2) Rod setback when the reactor period reaches $10 \mathrm{sec}$.

b. Above 1\% Rated Power:

1) An alarm from power-flow ratio when the neutron flux exceeds $7 \%$ of the full power flux.

2) Rod setback from power-flow ratio when the flux is more than $9 \%$ of full power flux.

3) Rod scram from power-flow ratio when the flux is $20 \%$ of full power flux.

4) An alarm indicating that the fuel channel outlet coolant temperature exceeds $975^{\circ} \mathrm{F}$.

5) Rod setback when the fuel channel outlet coolant temperature exceeds $1000^{\circ} \mathrm{F}$.

6) Rod scram when the fuel channel outlet coolant temperature exceeds $1025^{\circ} \mathrm{F}$, or exceeds a change of $50^{\circ} \mathrm{F}$ in any one hour.

The appropriate time of occurrence of each of these is shown on

Figure 55. It can be seen that in a normal system any one of these actions would have stopped the excursion before any thermal shock or physical damage could occur anywhere in the system.

2. Shim Rod Withdrawal Transient From Full Power

Shim rod withdrawal transients from full power are shown in Figures 56 and 57, with reactivity insertion rates of $0.03 \% / \mathrm{sec}$ and $0.001 \% / \mathrm{sec}$ respectively. 


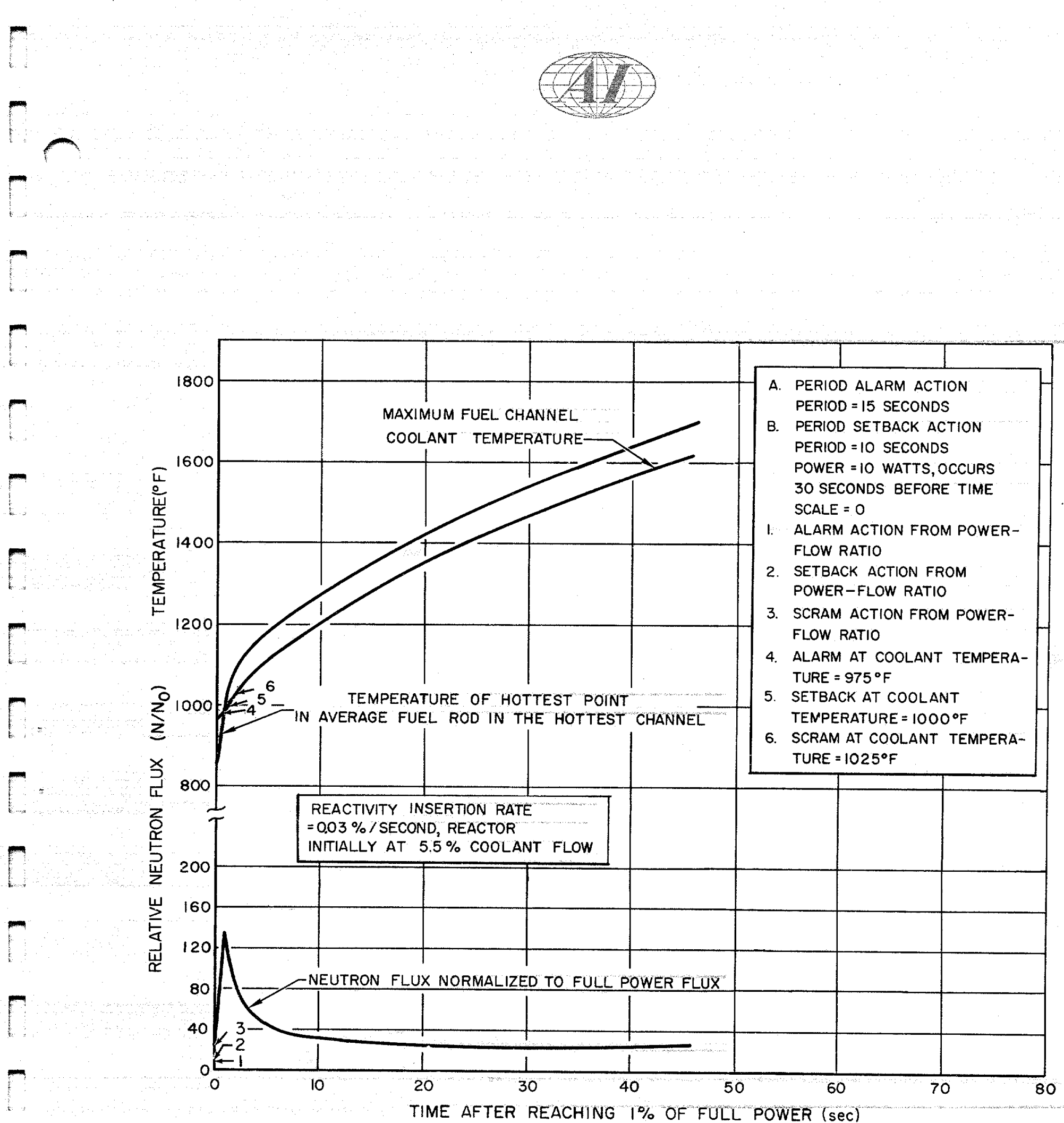

Figure 55. Temperatures and Relative Neutron Flux for Startup Transient Without Protective System Action 

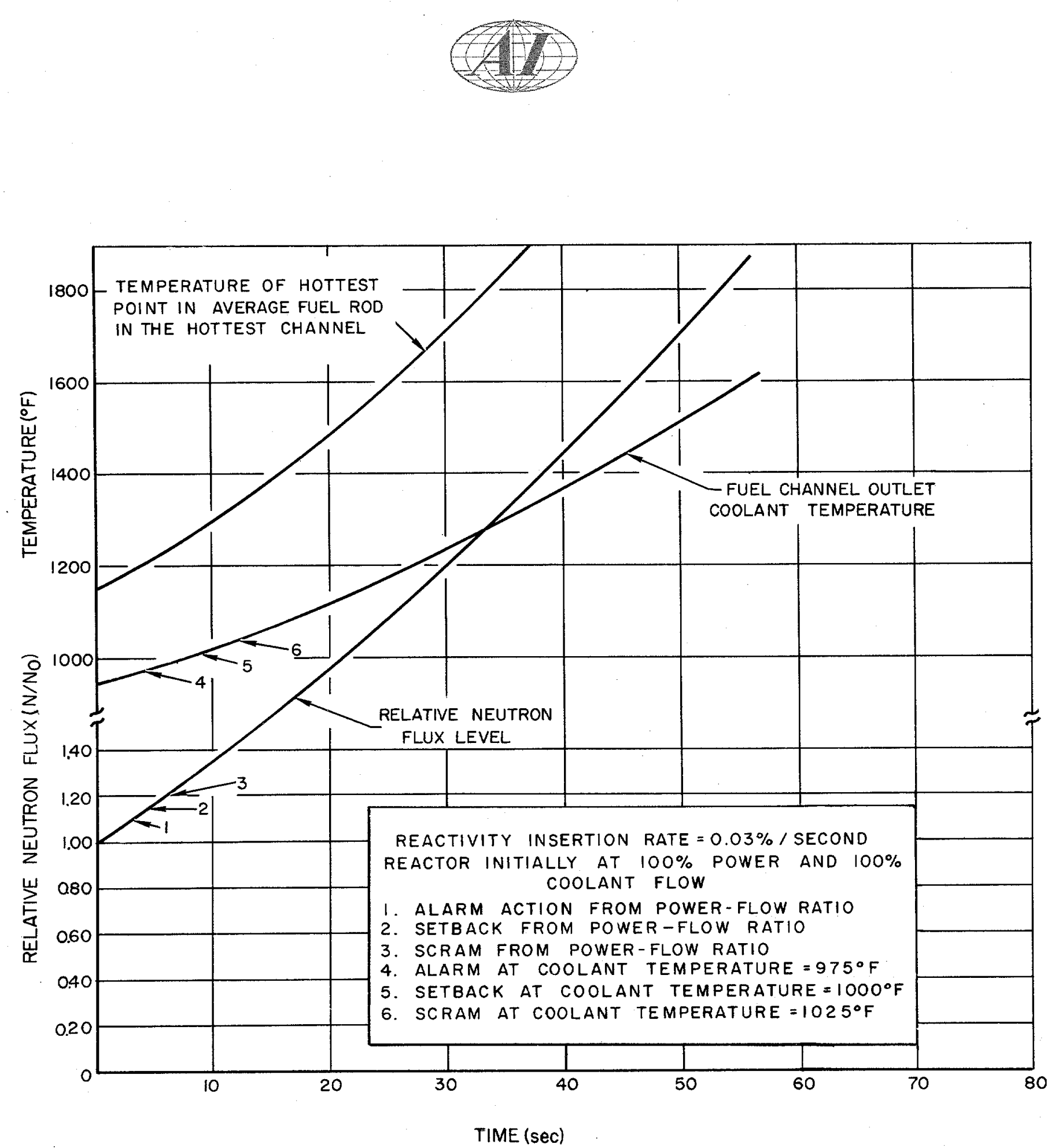

Figure 56. Temperatures and Relative Neutron Flux for Rod-Withdrawal Transient from Full Power Without Protective System Action 


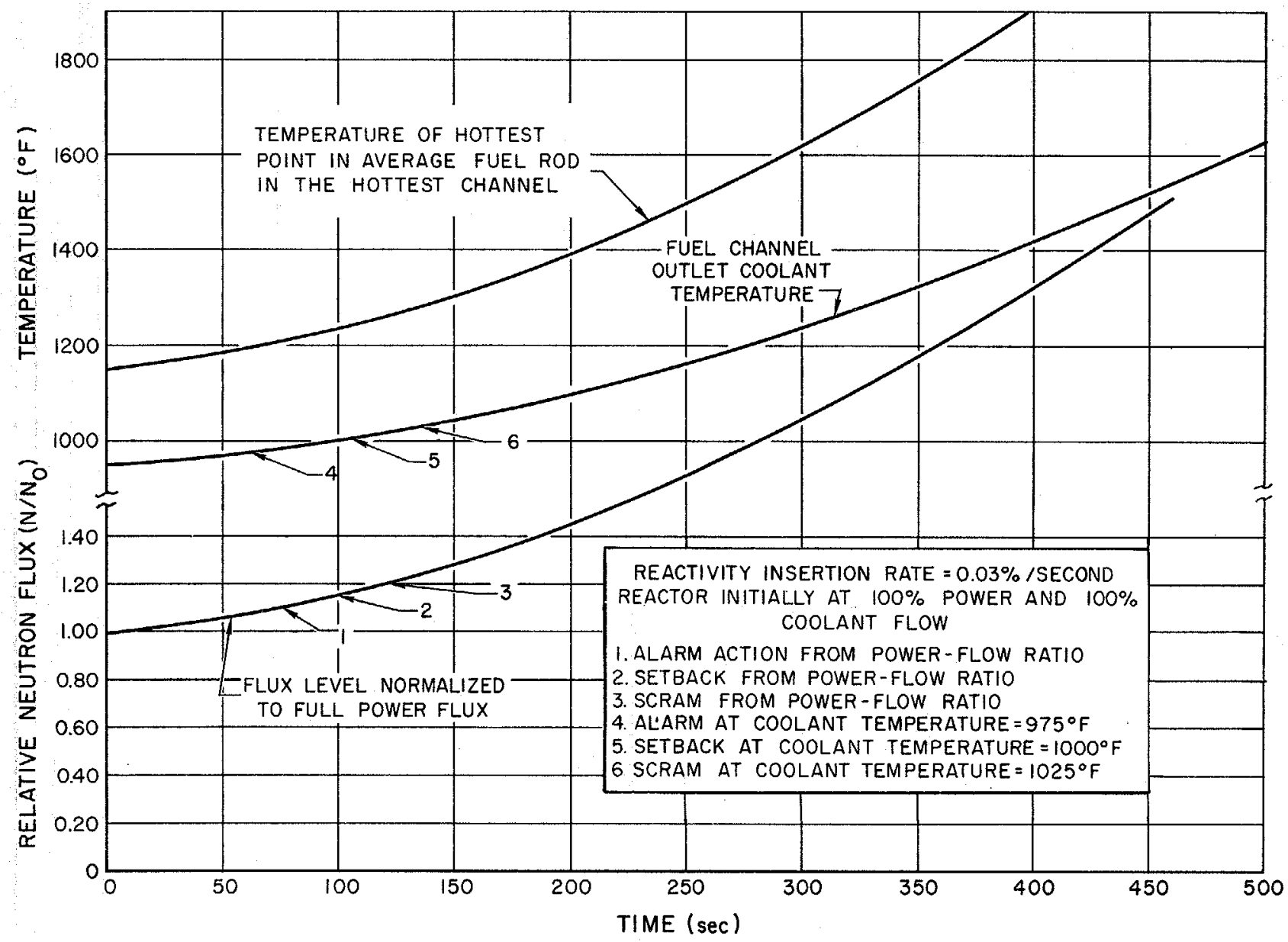

Figure 57. Temperatures and Relative Neutron Flux for Rod-Withdrawal Transient from Full Power Without Protective System Action 


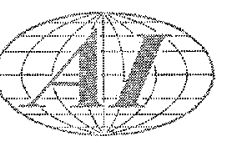

In the latter case, the upper plenum temperature would more closely follow the temperature of the sodium at the outlet of the fuel channel. Hence, the possibility would be greater for the sodium in the upper plenum to reach the boiling point.

The initial conditions for both transients are that the reactor be critical $\left(\mathrm{k}_{\text {eff }}\right.$ equal to 1.000$)$, and be at $100 \%$ rated power and flow. The transients are shown to the point where the fuel channel outlet coolant temperature reaches the boiling point which would be followed shortly thereafter by fuel meltdown. Both excursions assume the following protective system failures:

a) An alarm signal when the fuel channel outlet coolant temperature exceeds $975^{\circ} \mathrm{F}$.

b) An alarm signal from power-flow ratio when the neutron flux exceeds $110 \%$ of the full power flux.

c) Rod setback from power-flow ratio when the neutron flux exceeds $115 \%$ of the full power flux.

d) Rod scram from power-flow ratio when the neutron flux exceeds $120 \%$ of the full power flux.

e) Rod setback when the fuel channel outlet coolant temperature exceeds $1000^{\circ} \mathrm{F}$.

f) Rod scram when the fuel channel outlet coolant temperature exceeds $1025^{\circ} \mathrm{F}$, or exceeds a change of $50^{\circ} \mathrm{F}$ in any one hour.

\section{Loss of Forced Flow From Full Power}

A transient postulating complete loss of the three primary sodium pumps and a decay of the coolant flow rate to free convection is shown in Figure 58. It is assumed that the loss of flow is not accompanied by any protective system action. The neutron flux level and power decrease during the transient (because of the negative feedback effect of the fuel temperature on reactivity); and the sodium coolant temperature does not reach the boiling point.

The protective system failures which have been assumed in the loss of forced flow from full power are as follows:

XIII -20

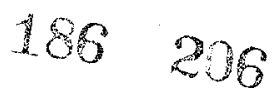



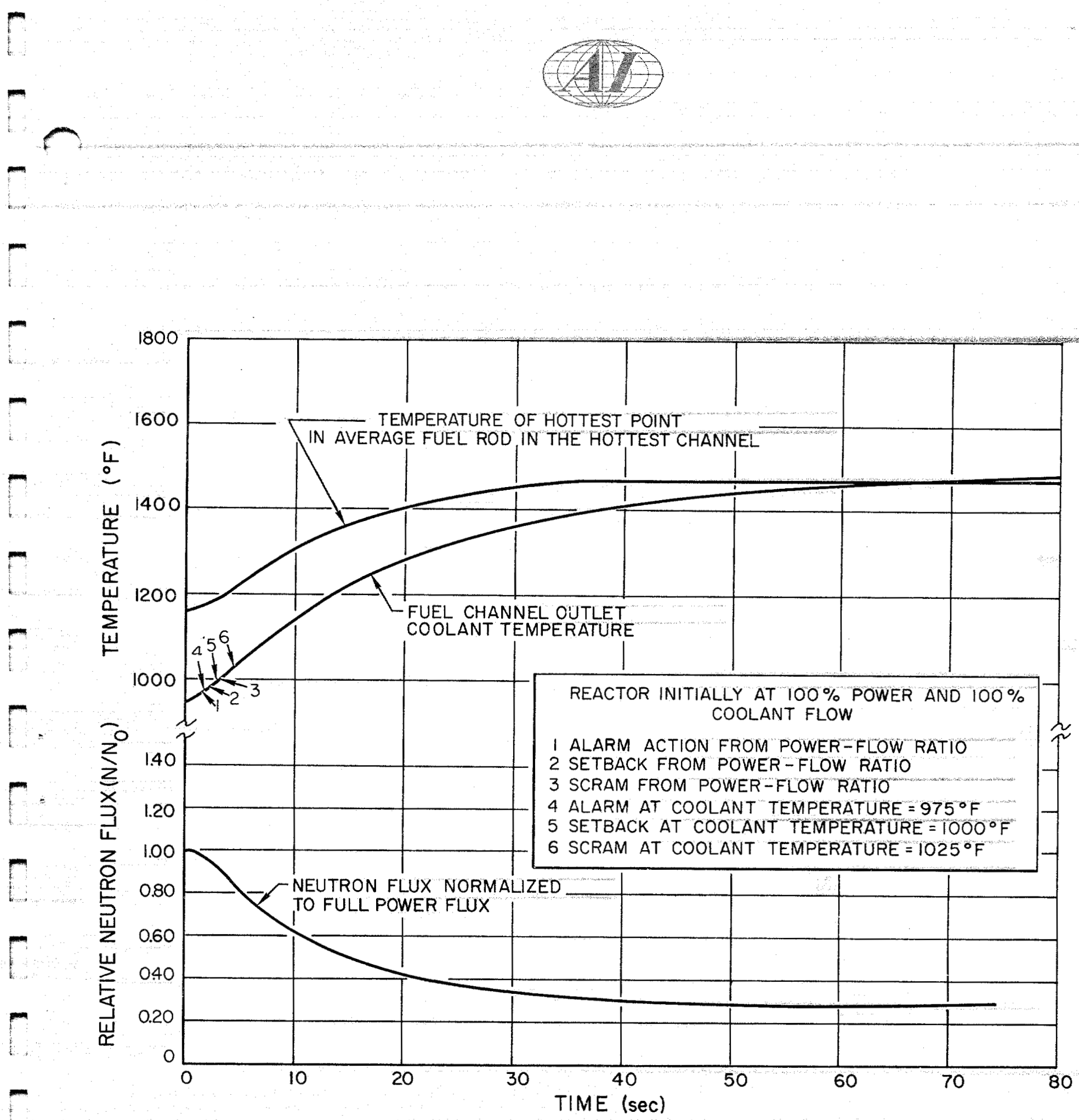

Figure 58. Temperatures and Relative Neutron Flux for Loss-of-PrimaryCoolant-Flow Transient Without Protective System Action 


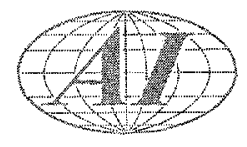

a) An alarm when the product of the coolant flow and temperature increase across the core reaches $90 \%$ of the full power level.

b) Rod setback when the product of the coolant flow and temperature increase across the core reaches $70 \%$ of the full power level.

c) An alarm when the fuel channel outlet coolant temperature exceeds $975^{\circ} \mathrm{F}$.

d) Rod setback when the fuel channel outlet coolant temperature exceeds $1000^{\circ} \mathrm{F}$.

e) Rod scram when the fuel channel outlet coolant temperature exceeds $1025^{\circ} \mathrm{F}$, or exceeds a change of $50^{\circ} \mathrm{F}$ in any one hour.

f) Rod scram when the electrical power to the coolant pump motors fails (involving any one of six pumps in the primary and secondary systems).

g) Rod scram when the primary to secondary coolant flow ratio exceeds the allowable limits as determined by the reactor power level.

\section{LOSS OF REACTOR HEAT SINK}

Each of the three heat transfer circuits (consisting of a primary and a secondary loop) is designed to transfer the full afterglow heat by natural convection flow of the coolant. There is an effective thermal head between the reactor core and the intermediate heat exchangers and between the intermediate heat exchangers and the steam generators (due to elevation and sodium temperature differences) which is sufficient to ensure the removal of afterglow heat without undesirable changes in the sodium temperature. The heat sink for the nuclear reactor is, in essence, the steam generators of the secondary system. The use of three separate steam generators, one in each of the sodium circuits, ensures continued capacity for the removal of thermal energy from the reactor core. The utilization of the steam is ensured, in turn, either by continued turbine operation, by the direct dumping of the steam into the atmosphere boiler (steam dumping system), or by direct discharge of the steam to the atmosphere.

If the condenser and the atmospheric boiler should become inoperative, so that no return feedwater is supplied to the steam generators, there is emergency 
feedwater available from a 60,000 gal. storage tank plus the deaerating heaters, etc. Since the total integrated energy available from afterglow power would only evaporate 77,000 gal. of water the emergency supply has an adequate capacity to absorb the afterglow energy from the reactor.

However, to indicate the over-all safety of the system, the worst possible situation for losing the heat removal capacity of the coolant has been studied. The incident considered is the loss of all convective flow (free or forced convection) in all three primary coolant loops after a scram. It is assumed that the only cooling system available is that in the top loading face of the reactor and in the cavity liner. Normal cooling capacity has been disregarded for the following components:

1) Steam generators.

2) Heat losses from sodium piping in secondary system.

3) Heat losses from primary piping.

4) No energy removal capacity from helium gas in the reactor and in the reactor cavity.

Loss of all convective flow in all three primary coolant loops of the reactor could result from the following highly unlikely sequence, carried to completion, and then allowed to remain in this condition:

1) The reactor is scrammed.

2) Sodium flow control valves start closing as programmed by the plant control system.

3) Three separate interlocks, which usually prevent complete closure of the valves, fail and allow the valves to close completely.

4) All three valves stick closed and cannot be reopened.

The accident is a serious consideration only when all three loops are closed, since free convective flow in a single primary sodium loop is sufficient to remove all of the afterglow heat without excessive temperature rise of the reactor.

Because there are sufficient internal conduction paths in the reactor core to allow the core to heat up uniformly, and assuming that, prior to the scram action, the reactor has been operating at full power for a period of one year, then the 
afterglow energy is sufficient to heat the total mass in the reactor to the sodium boiling temperature in approximately 24 hours.

At this time, the sodium would commence boiling at a constant temperature and the vapor would be condensed on the top shield and returned to the sodium pool. Adequate cooling is available in the top shield, in addition to cooling by the cavity liner, to remove the afterglow heat and to prevent pressurization of the reactor. Thus, no hazard arises as a result of this situation, which could be halted at any time if any one of the three primary sodium valves were reopened. 


\section{ACCIDENT EVALUATION AND CONCLUSIONS}

The foregoing sections have presented a detailed discussion of the potential hazards and the controlling safeguards for the HNPF. Discussions of potentially hazardous incidents have been presented without regard to their credibility, the evaluation of accident credibility being retained for presentation in this section of the report. By carefully considering all of the factors which influence the concept of credibility, incidents can be classified as being either credible or incredible. From those incidents classified as credible, the maximum credible accident is designated as that credible accident which has the greatest level of radioactivity hazard associated with it. No regard has been given to physical damage or cost of recovery from the accidents postulated.

\section{A. SUMMARY OF INCIDENTS}

Many incidents are discussed in Part II of this report. Each of these incidents is briefly reviewed in Table XXIII. Consideration of the number of system failures required to permit the postulation of each incident, and concern for the degree of the potential hazard associated with the incident, have led to the conclusions on credibility indicated in Table $I$.

\section{B. THE MAXIMUM CREDIBLE ACCIDENT}

Based on the foregoing discussion, the maximum credible accident for the HNPF is designated as the accident in which a control rod thimble fails in the region of the helium atmosphere within the reactor vessel. The helium gas in the thimble is permitted to leak out into the reactor vessel and there is a complete intermixing of the thimble atmosphere and the reactor atmosphere due to a failure of the thimble helium supply system. The activity within the control rod drive housing rises to the activity level of the reactor atmosphere, and this activity level acting as a radiation source causes a radiation dosage of $10 \mathrm{r} / \mathrm{hr}$ at a distance of $1 \mathrm{ft}$ from the source. At the nearest site boundary the dosage from this source would be much less than $0.1 \mathrm{mr} / \mathrm{hr}$. A complete discussion of this accident is presented in section IX-A. 
TABLE XXIII

SUMMARY OF POTENTIAL HAZARDS

\begin{tabular}{|c|c|c|c|c|c|}
\hline & Incident & $\begin{array}{l}\text { System Failure to Permit } \\
\text { Postulation of Incident }\end{array}$ & Remarks & Consequent Radiation Dosage & Credible \\
\hline & $\begin{array}{l}\text { Pressurization of Inert } \\
\text { Atmosphere }\end{array}$ & & & & \\
\hline & a) Pipe tunnel & $\begin{array}{l}\text { Loss of heat exchanger cooling } \\
\text { water system }\end{array}$ & $\begin{array}{l}\text { No excess pressure buildup. } \\
\text { Emergency cooling watex } \\
\text { supply available }\end{array}$ & None & Yes \\
\hline & $\begin{array}{l}\text { b) Intermediate heat } \\
\text { exchanger cells }\end{array}$ & Same as 1 (a) & Same as $1(a)$ & None & Yes \\
\hline & $\begin{array}{l}\text { c) Within reactor cavity } \\
\text { because of sodium leak }\end{array}$ & $\begin{array}{l}\text { Pipe fracture or core tank } \\
\text { fracture }\end{array}$ & $\begin{array}{l}\text { Secondary confinement by guard } \\
\text { pipe and reactor outer vessel }\end{array}$ & None & No \\
\hline & $\begin{array}{l}\text { d) In pipe tunnel or inter- } \\
\text { mediate heat exchanger } \\
\text { cell due to small sodium } \\
\text { leak }\end{array}$ & $\begin{array}{l}\text { Small fissure in stainless steel } \\
\text { pipe }\end{array}$ & $\begin{array}{l}\text { SRE experience has shown this } \\
\text { could easily be handled }\end{array}$ & None & Yes \\
\hline & $\begin{array}{l}\text { e) In pipe tunnel or inter- } \\
\text { mediate heat exchanger } \\
\text { cell due to large sodium } \\
\text { leak }\end{array}$ & Major fracture of sodium pipe & $\begin{array}{l}\text { Major pipe fracture in a low } \\
\text { pressure sodium system is } \\
\text { unreas sonable }\end{array}$ & None & No \\
\hline & $\begin{array}{l}\text { Pressurization of Reactor by } \\
\text { Helium Supply and Relief } \\
\text { System Failure }\end{array}$ & $\begin{array}{l}\text { Failure of } 2 \text { sets of } 3 \text { valves } \\
\text { and a rupture disk }\end{array}$ & $\begin{array}{l}\text { Helium supply is limited - no } \\
\text { exceas pressure buildup }\end{array}$ & None & No \\
\hline & $\begin{array}{l}\text { Fuel Handling Cask-Loss of } \\
\text { Forced Helium Cooling }\end{array}$ & & & & \\
\hline & $\begin{array}{l}\text { a) Low burnup fuel element } \\
\text { first one in cask }\end{array}$ & $\begin{array}{l}\text { Mechanical (or electrical) fail- } \\
\text { ure of helium blower }\end{array}$ & $\begin{array}{l}\text { Water cooling of cask walls is } \\
\text { assumed to continue }\end{array}$ & None & Yes \\
\hline & $\begin{array}{l}\text { b) High burnup fuel element } \\
\text { is first one in cask }\end{array}$ & Same as 3(a) & $\begin{array}{l}\text { Same as } 3(\text { a) plus violation of } \\
\text { operational procedures }\end{array}$ & $\begin{array}{l}6 \times 10^{-6} \mu \mathrm{c} / \mathrm{cm}^{3} \text { in reactor } \\
\text { room atmosphere }\end{array}$ & Yes \\
\hline & $\begin{array}{l}\text { Leak in Steam Generator } \\
\text { Duplex Tube }\end{array}$ & & & & \\
\hline & a) Single wall & Single tube failure & $\begin{array}{l}\text { Crack occurs in high strength } \\
\text { alloy which has undergone } \\
\text { extensive inspection before } \\
\text { usage, and is not detected by } \\
\text { monitoring fluid }\end{array}$ & None & Yes \\
\hline & b) Double wall-small leak. & Double tube failure & $\begin{array}{l}\text { More than twice as unreason- } \\
\text { able as } 4 \text { (a) since both failures } \\
\text { would have to occur at same } \\
\text { location }\end{array}$ & None & No \\
\hline & Leak in Control rod Thimble & & & & \\
\hline & a) In sodium region & Tube failure & $\begin{array}{l}\text { Thimble would be changed when } \\
\text { leak detected }\end{array}$ & None & Yes \\
\hline & b) In helium region & $\begin{array}{l}\text { Same as } 5 \text { (a) plus failure of } \\
\text { helium supply system for the } \\
\text { thimble }\end{array}$ & $\begin{array}{l}\text { Same as } 5(\text { a); plus failure of } \\
\text { helium supply system for the } \\
\text { thimble not being detected }\end{array}$ & $\begin{array}{l}\text { 10 r/hr at } 1 \text { ft from rod } \\
\text { carriage if thimble not } \\
\text { removed from core }\end{array}$ & Yes \\
\hline 6. & $\begin{array}{l}\text { Flow-Power Mis-match in } \\
\text { One Fuel Channel }\end{array}$ & & & & \\
\hline & a) At low reactor power & $\begin{array}{l}\text { Variable area orifice not } \\
\text { adjusted properly }\end{array}$ & $\begin{array}{l}\text { Operational procedure calls } \\
\text { for proper adjustment at low } \\
\text { flow. Temperature signal } \\
\text { not heeded. No fuel melting }\end{array}$ & None & Yes \\
\hline & b) At high reactor power & Same as $6(a)$ & $\begin{array}{l}\text { Same as 6(a) plus fact warn- } \\
\text { ings continue to go unheeded, } \\
\text { Element melts }\end{array}$ & None & No \\
\hline 7. & Loss of Reactor Heat Sink & $\begin{array}{l}\text { Complete loss of secondary } \\
\text { system cooling capacity }\end{array}$ & $\begin{array}{l}\text { Totally unrealistic to as sume } \\
\text { reactor is unattended for } 24 \mathrm{hr}\end{array}$ & None & No \\
\hline 8. & $\begin{array}{l}\text { Rupture of Primary Sodium } \\
\text { Pipe and Subsequent Fire }\end{array}$ & $\begin{array}{l}\text { Same as } 1(e) \text { plus primary } \\
\text { system confinement violated } \\
\text { to permit oxygen to be present }\end{array}$ & $\begin{array}{l}\text { Same as } 1(e) \text { plus unlikely } \\
\text { occurrence of excess oxygen } \\
\text { being present in nitrogen } \\
\text { atmosphere }\end{array}$ & $\begin{array}{l}\text { 87r total integrated dosage } \\
\text { at Hallam, Nebr. }\end{array}$ & No \\
\hline & $\begin{array}{l}\text { Fission Gas Release Through } \\
\text { Loading Face Shield }\end{array}$ & $\begin{array}{l}\text { Multiplicity of reactor gas } \\
\text { seals have failed }\end{array}$ & $\begin{array}{l}\text { Low pressure gas system pre- } \\
\text { cludes any large gas release } \\
\text { from the reactor }\end{array}$ & $\begin{array}{l}\text { Max. dosage is } 0.6 r \text { total } \\
\text { integrated dosage at Hallam, } \\
\text { Nebr. }\end{array}$ & No. \\
\hline 10. & Nuclear Excursions & $\begin{array}{l}\text { Total failures of control sys- } \\
\text { tem, protective system, and } \\
\text { no action by plant operating } \\
\text { personnel }\end{array}$ & $\begin{array}{l}\text { Leads to ultimate shut down } \\
\text { of reactor }\end{array}$ & None & No \\
\hline
\end{tabular}




\section{APPENDIX A \\ AUTOCATALYTIC RELEASE OF WIGNER ENERGY IN HNPF \\ (by R. L. Carter)}

\section{A. STATEMENT OF PROBLEM}

Will sufficient energy be stored in the graphite as a result of radiation damage to present a hazard from autocatalytic release of Wigner energy in the $\mathrm{HNPF}$, in which $\mathrm{graphite}$ will operate in the range 600 to $800^{\circ} \mathrm{F}\left(316\right.$ to $\left.427^{\circ} \mathrm{C}\right)$ ?

\section{B. SUMMARY OF RESULTS AND RECOMMENDATIONS}

Release of Wigner energy stored under HNPF irradiation conditions will not contribute significantly toward an autocatalytic rise of moderator temperature in the HNPF. No special precautions are recommended on account of this consideration.

\section{METHOD USED, SAMPLE CALCULATIONS}

1. It is postulated that all cooling is removed from the graphite stack and that through some hypothetical means the entire store of Wigner energy is released in the graphite. An adiabatic rise in temperature occurs whose amplitude is given by integration of the following equation:

$$
\int_{T_{0}}^{T} C(d T)=\mathbb{W}_{0}
$$

where

$$
C=\text { the specific heat of graphite as a function of temperature, }
$$$$
W_{0}=\text { the Wigner energy released, }
$$$$
T=\text { the graphite temperature, }
$$$$
T_{0}=\text { the initial graphite temperature . }
$$ 
If the temperature amplitude of such computed adiabatic rise is markedly less than the temperature rise required to lead to the postulated release of Wigner energy, no autocatalytic release is possible.

2. Total stored energy in graphite as a function of integrated exposure is shown in Figure 59 for irradiation temperatures of 600 to $800^{\circ} \mathrm{F}$ ( 316 and $427^{\circ} \mathrm{C}$ ). Assuming a peak fast flux of $5 \times 10^{13} \mathrm{~cm}^{-2} \mathrm{sec}^{-1}$, stored energy content of the most heavily irradiated graphite would extend from $20 \mathrm{cal} / \mathrm{g}$ to $55 \mathrm{cal} / \mathrm{g}$, temperatures of irradiation of 800 to $600^{\circ} \mathrm{F}$, respectively, after $5 \mathrm{yr}$ irradiation.

The high temperature specific heat of graphite is not appreciably affected by radiation damage. Utilizing the curve for specific heat vs temperature (Figure 60 ), it is seen that complete release of the stored energy under adiabatic conditions causes the graphite temperature to rise to about $915^{\circ} \mathrm{F}\left(490^{\circ} \mathrm{C}\right)$ in both cases. This small rise in temperature will serve to release only a fraction of the total stored energy whose release was postulated. It is seen therefore that no autocatalytic release is possible due to Wigner energy release.

\section{REFERENCES}

R. Fletcher, HW-36221, (AEC Classified Report), September 1956 Proceedings of the US/UK Conference on Graphite (Classified), London, England, December 1957 

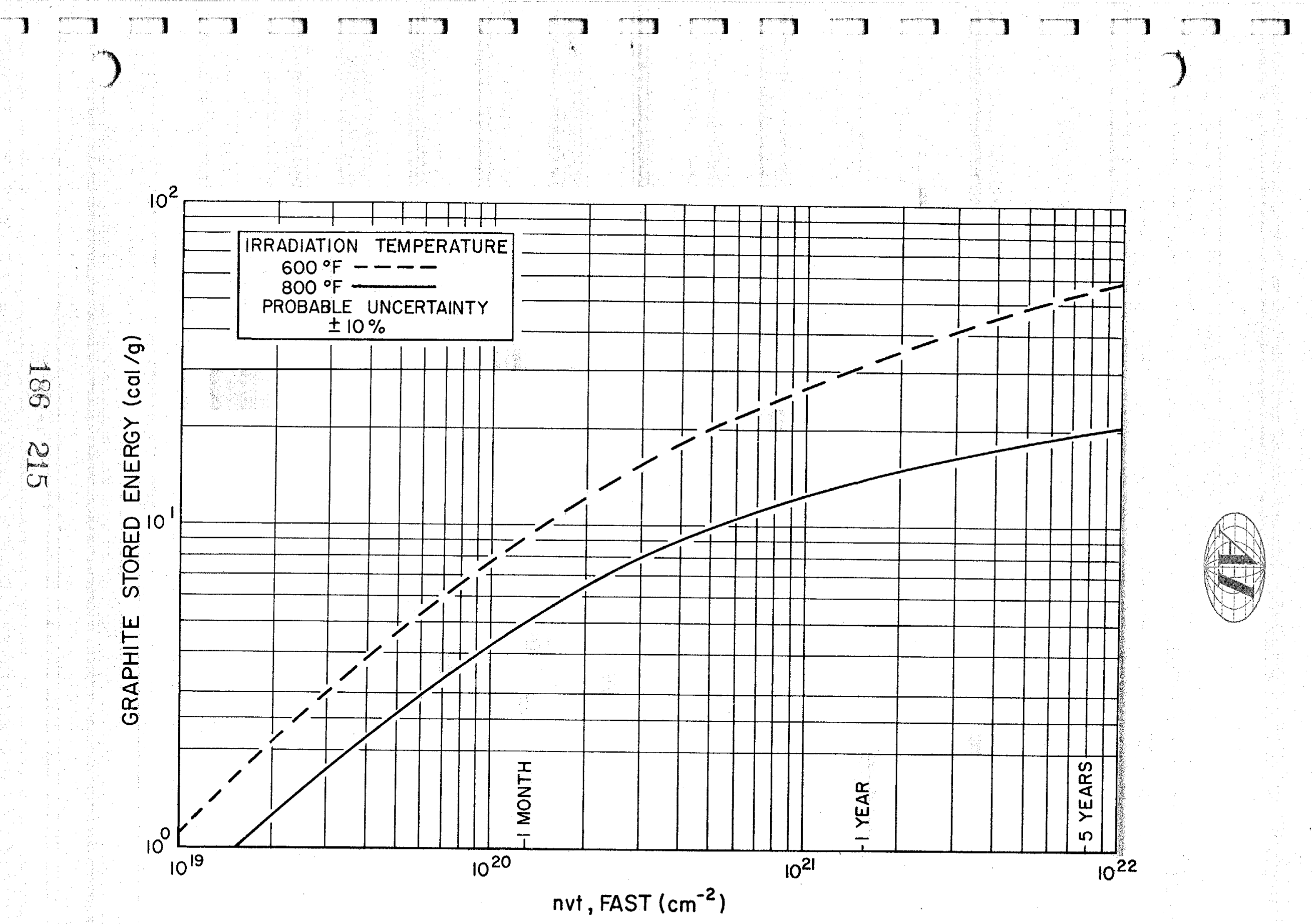
$?$

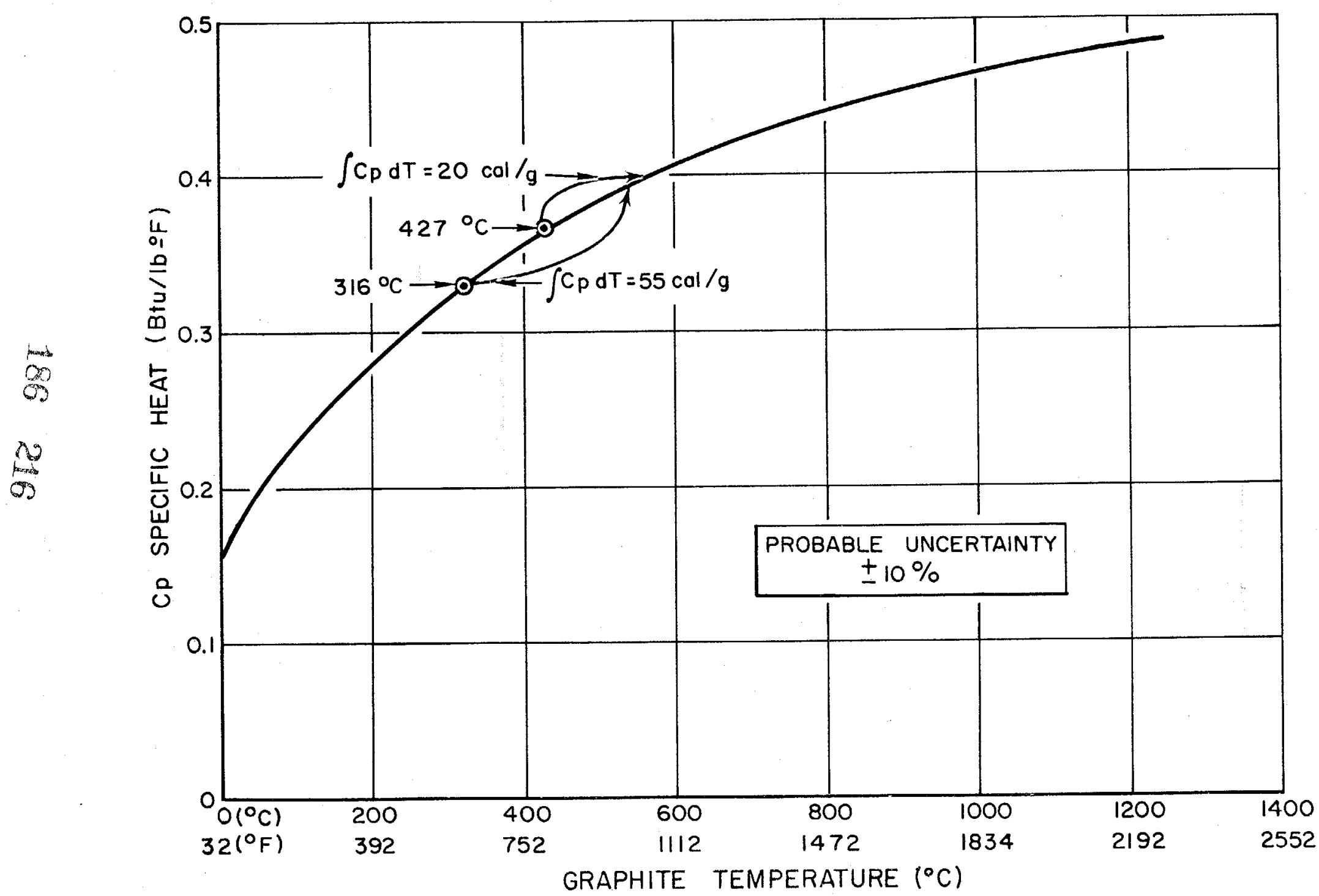

Figure 60. Variation of Graphite Specific Heat with Measurement Temperature 


\section{APPENDIX B \\ DESCRIPTION OF REACTOR POWER AND TEMPERATURE TRANSIENT STUDIES}

The general objective of the study was to observe reactor neutron flux level and temperatures during reactivity insertion by rod withdrawal or changes in coolant flow. Analog simulation techniques were used to solve the space and time dependent equations which describe the reactor core power and temperature transient behavior. Several abnormal operating conditions were imposed upon the simulated reactor core; the response of the reactor simulator to the various reactivity and coolant flow driving functions is discussed in section XII. Scram circuits were simulated on the analog in order to synthesize an adequate protective system.

\section{A. ANALOG MODEL}

The reactor core is a matrix of vertical fuel channels, fuel elements, and moderator logs. Sodium coolant flows through the fuel channels and around the moderator cans (section IV). Since all the fuel channels and moderator cans are identical, a unit cell model consisting of the average fuel element in the hottest fuel channel, an adjacent moderator can, and the associated coolant were chosen to represent the reactor core. The reactor unit cell model is shown in Figure 61. The representative fuel element and moderator log were thermally coupled, by means of the appropriate areas for heat transfer. The unit cell model was divided into axial and radial nodes to accommodate spatial dependence of neutron flux and reactor temperatures. The fuel rod was arranged into five axial nodes and three radial nodes. Five axial nodes were used in the fuel coolant, five axial nodes in the moderator coolant and five axial nodes in the moderator.

\section{Nuclear Parameters}

The analog computer was programmed to accommodate the kinetic behavior of the neutron flux from one to several hundred percent of the full power heat generation rate. For the startup transients, the neutron kinetic behavior from 


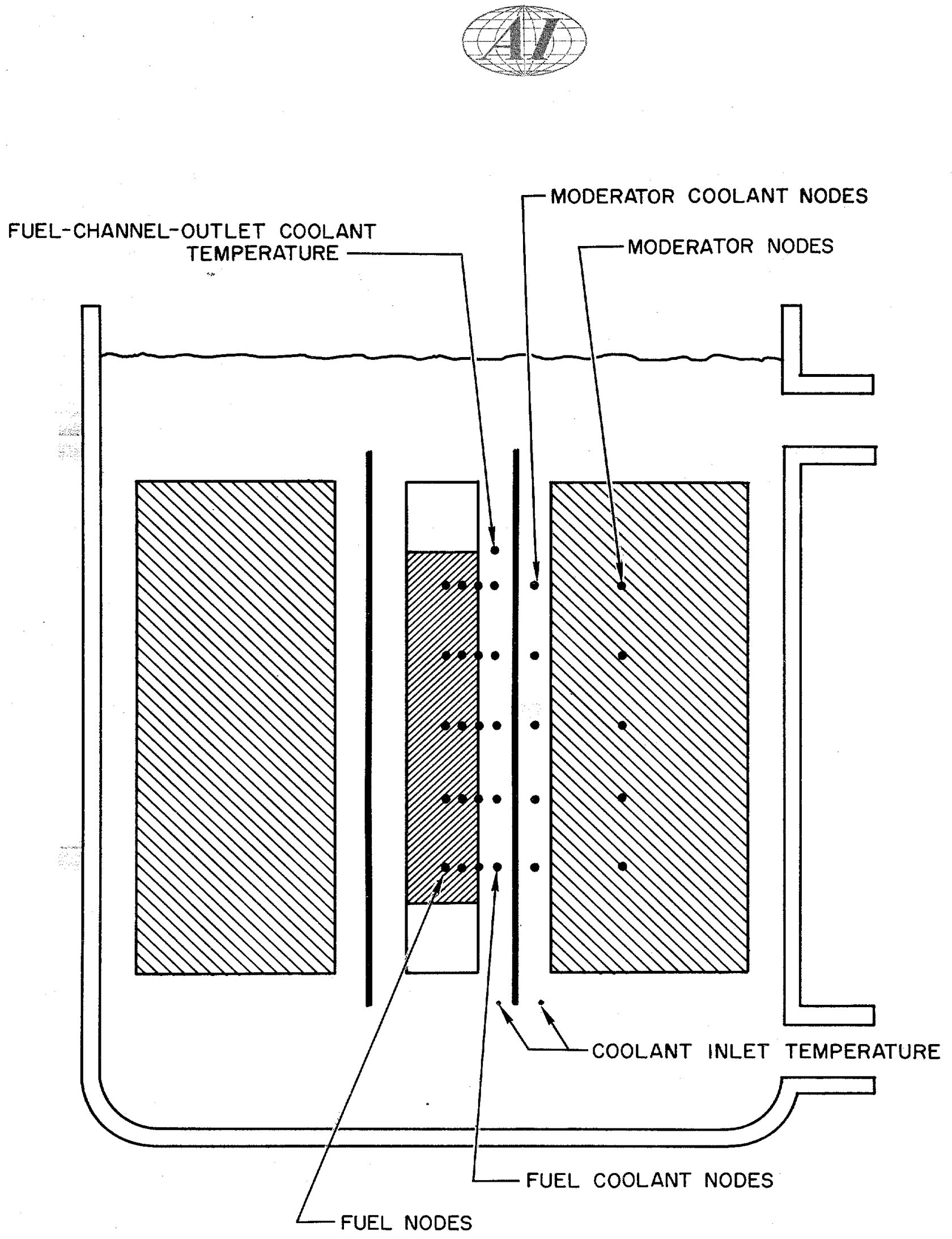

Figure 61. Unit Cell Model for Representative Fuel Channel and Graphite Moderator Can

B -2 



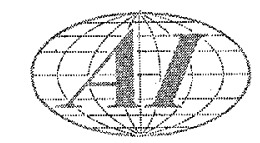

coolant, and (d) moderator sodium coolant. During a transient, these components change temperature at different rates; and, as such, their resultant reactivity effects were considered separately. However, the total temperature feedback reactivity can be approximated by the sum of these individual effects. The fuel element reactivity contribution was estimated, based on the hot fuel channel, by taking the weighted average fuel temperature, with its importance function, integrated over the whole core and considering the two effects that change fuel temperature, namely: (a) changes in coolant temperature, and (b) changes in heat generation within the fuel. Similarly, the graphite moderator reactivity contribution was estimated, considering both moderator coolant temperature changes and heat generation rate changes. Also, the coolant reactivity terms were estimated by using the importance weighted, integrated core-averaged coolant temperatures. The integrated averaging calculation was modified for nodal approximations.

Thus, the reactivity power coefficient approximation, using the hot channel as a basis, was calculated to give a realistic picture of the whole core temperature reactivity feedback.

\section{B. ANALOG SIMULATOR PROGRAM}

The analog computer was programmed as closely as possible, within equipment limitations, to simulate the HNPF reactor core including the neutron kinetics, thermodynamics, and primary loop sodium flow behavior. Power changes were made by ramp reactivity insertion to simulate shim-regulating rod movement, and flow changes were simulated by pump speed variation.

In addition to rod insertion and withdrawal simulation, reactor-flow ratio and temperature scram circuits were simulated. Appropriate transducer and system time delays were included. The computer program is shown in schematic form in Figure 62 . 
